Gleica Soyan Barbosa Alves

Eliene de Oliveira

(Organizadoras)

Tópicos em Ciências da Saúde Volume 26

1a Edição

Belo Horizonte

Poisson

2021 
Editor Chefe: Dr. Darly Fernando Andrade

\section{Conselho Editorial}

Dr. Antônio Artur de Souza - Universidade Federal de Minas Gerais

Msc. Davilson Eduardo Andrade

Dra. Elizângela de Jesus Oliveira - Universidade Federal do Amazonas

Msc. Fabiane dos Santos

Dr. José Eduardo Ferreira Lopes - Universidade Federal de Uberlândia

Dr. Otaviano Francisco Neves - Pontifícia Universidade Católica de Minas Gerais

Dr. Luiz Cláudio de Lima - Universidade FUMEC

Dr. Nelson Ferreira Filho - Faculdades Kennedy

Msc. Valdiney Alves de Oliveira - Universidade Federal de Uberlândia
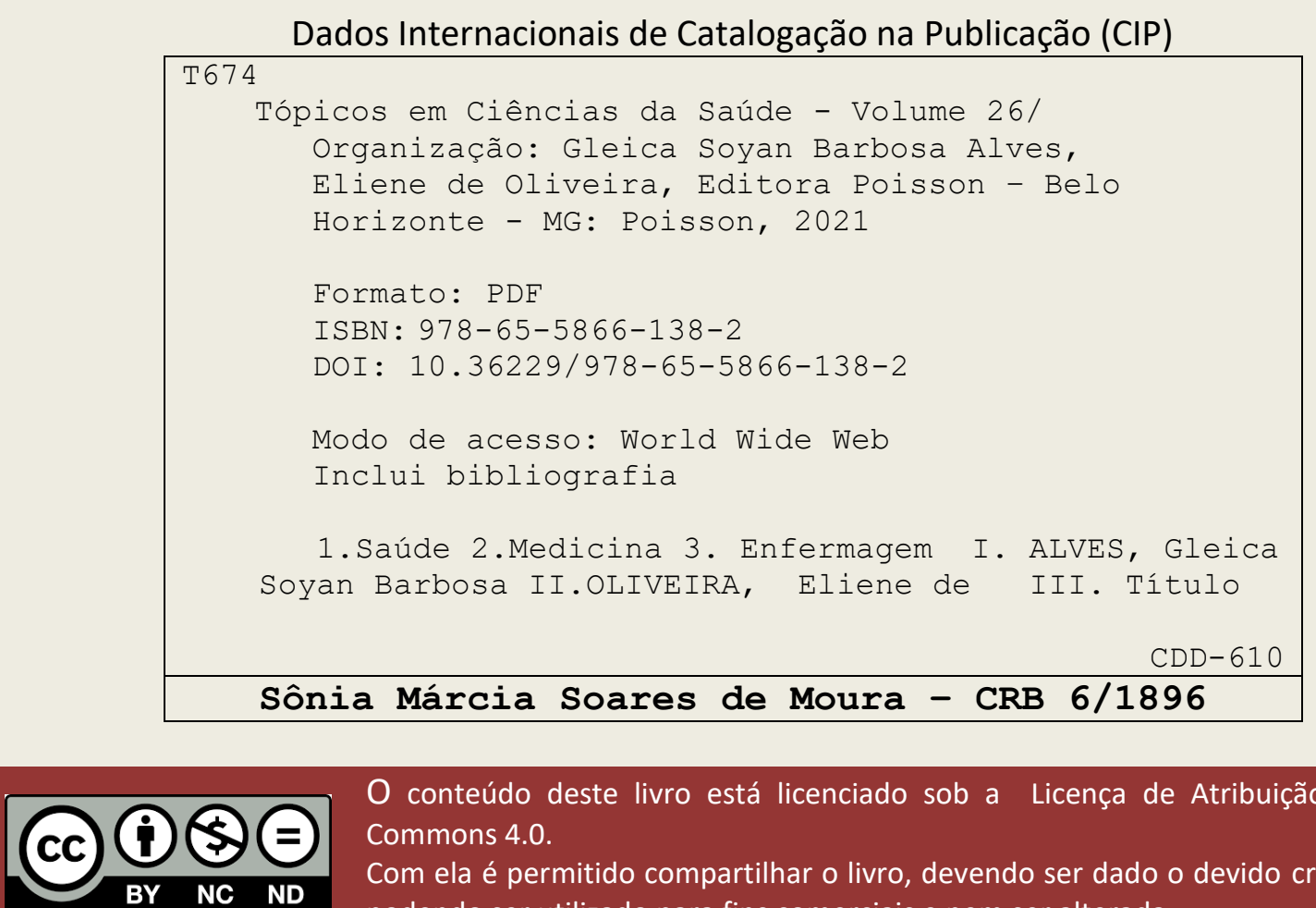

O conteúdo deste livro está licenciado sob a Licença de Atribuição Creative Commons 4.0.

Com ela é permitido compartilhar o livro, devendo ser dado o devido crédito, não podendo ser utilizado para fins comerciais e nem ser alterada.

O conteúdo dos artigos e seus dados em sua forma, correção e confiabilidade são de responsabilidade exclusiva dos seus respectivos autores.

Esse e outros títulos podem ser baixados gratuitamente em www.poisson.com.br Entre em contato pelo contato@poisson.com.br 


\section{SUMÁRIO}

Capítulo 1: Tensão do papel de cuidador em familiares de idosos: Compreensão à luz da revisão integrativa da literatura. 07

Lara de Sá Neves Loureiro, Maria Auxiliadora Pereira, Maria das Graças Melo Fernandes

DOI: 10.36229/978-65-5866-138-2.CAP.01

Capítulo 2: 0 cuidador e suas práticas em saúde: Interações e influências na adesão ao tratamento odontológico entre adolescentes.

Jaqueline Vilela Bulgareli, Luciane Miranda Guerra, Camila Gonçalo Mialhe, Brunna Verna Castro Gondinho, Alcir José de Oliveira Júnior, Marcelo de Castro Meneghim, Sílvia Letícia Freddo, Karine Laura Cortelazzi Mendes, Antonio Carlos Pereira

DOI: 10.36229/978-65-5866-138-2.CAP.02

Capítulo 3: Papel de enfermería en el sistema de cuidados familiares cuidadora extranjera-persona mayor dependiente

María José Morales-Gázquez, Epifanía Natalia Medina-Artiles, María Milagros Torres-Garcia, Maria del Carmen Navarro Rodrígues, Carmen Trigueros-Cervantes

DOI: $10.36229 / 978-65-5866-138-2 . C A P .03$

Capítulo 4: Adaptación del Modelo del Sol Naciente de Leininger a la cuidadora extranjera con el objetivo de determinar los factores culturales que afectan a su labor de cuidar de una persona mayor dependiente 31

María José Morales-Gázquez, Epifanía Natalia Medina-Artiles, Maria del Carmen Navarro Rodrígues, María Milagros Torres-Garcia, Carmen Trigueros-Cervantes

DOI: $10.36229 / 978-65-5866-138-2 . C A P .04$

Capítulo 5: Pictogramas no processo de cuidado farmacêutico 37

Carine Viana Silva, Letícia Bittencourt Turra

DOI: 10.36229/978-65-5866-138-2.CAP.05

Capítulo 6: Produção de vídeos didático-pedagógicos para o canal Remov Online ... 45 Gustavo Simão Moraes, Fabio Brasil de Oliveira, Rosana Marques Silva Figuerôa, Alfonso Sánchez-Ayala, Nara Hellen Campanha Bombarda, Vanessa Migliorini Urban

DOI: $10.36229 / 978-65-5866-138-2 . C A P .06$

Capítulo 7: Competências pedagógicas e saúde dos docentes em Educação à Distância 56

Veridiana de Vasconcelos Duarte, Regiane da Silva Macuch, Arthur Gualberto Bacelar da Cruz Urpia DOI: 10.36229/978-65-5866-138-2.CAP.07 


\section{SUMÁRIO}

Capítulo 8: Promover saúde educando hábitos em Escola de Ensino Fundamental no Sul da Bahia. 63

Cecilia Rodrigues da Silva Neta, Sandro Menezes de Oliveira, Patrycia Batista Nery Silva, João Luis Almeida da Silva, Aretusa de Oliveira Martins Bitencourt

DOI: $10.36229 / 978-65-5866-138-2 . C A P .08$

Capítulo 9: Uso do Lian Gong na promoção da saúde em uma escola pública de um município do Sul da Bahia.

Caroline Dias Brandão, Marleide Mateus de Jesus, Samanta Santana da Silva, Valdeir Almeida Santos, Nayara Alves Severo, João Luis Almeida da Silva

DOI: 10.36229/978-65-5866-138-2.CAP.09

Capítulo 10: A voz profissional em tempo de Covid -19: Uma experiência fonoaudiológica para professores da Rede Municipal de Campos dos Goytacazes..... 80

Ilma Alessandra Lima Cabral Rodrigues, Isabela Dutra Coelho Brandt, Elizabeth Matilda Oliveira Williams, Tânia Machado de Carvalho

DOI: $10.36229 / 978-65-5866-138-2 . C A P .10$

Capítulo 11: Síndrome inflamatória multissistêmica após infecção por COVID-19 em crianças: Uma revisão integrativa da literatura 86

Marina Gontijo Tuyama, Amanda Schmitberger Pelisson, Ana Clara Camargo Rocha, Isabelle Faria Safadi, Laura Andrade Almeida, Luisa Andrade de Almeida, Rafaela Valadares Zucconi, Silvia Andrade Lopes, Taina Wendling Gama

DOI: $10.36229 / 978-65-5866-138-2 . C A P .11$

Capítulo 12: Estratégias para prevenção do câncer de testículo e a importância do enfermeiro: Revisão de literatura 96

Silvia Roberta de Lima Cardoso, Raquel Mendes Rubenick, Alexandre Lazzarini Machado, Mirela Tonato Vieira, Kelin Rodrigues Aguiar, Simone dos Santos Nunes

DOI: $10.36229 / 978-65-5866-138-2 . C A P .12$

Capítulo 13: Rastreamento de câncer de mama em Alagoas: Uma análise a partir dos dados do sistema de informações do Sistema Único de Saúde. 102

Martta Laiany Martins Machado, Jucélia Rodrigues Oliveira, Zenaira da Silva Santos, Josefina da Silva Santos

DOI: $10.36229 / 978-65-5866-138-2 . C A P .13$ 


\section{SUMÁRIO}

Capítulo 14: Reabilitação fisioterapêutica com o uso do kinect para tratamento de sequelas em pacientes com Acidente Vascular Encefálico - Revisão de literatura ...... 110

Carlos Eduardo de Almeida, Dalvana Cristina de Carvalho Elesbão, Keila Carmen de Oliveira Silva Bassanelli, Marcela dos Santos Teixeira, Pedro Luiz Maruco dos Anjos, Ronaldo Paulo Merenda, Ana Carolina Ricardo Fernandes, Daniel Tineu Leite Maia

DOI: $10.36229 / 978-65-5866-138-2 . C A P .14$

Capítulo 15: Síntese e caracterização de policátions bioresponsivos com potencial de aplicações no carregamento de genes. 114

Paulo Cesar Rodrigues

DOI: $10.36229 / 978-65-5866-138-2 . C A P .15$

Capítulo 16: Roteiro conceitual para um instrumento de coleta de dados para avaliação de pacientes pediátricos 125

Deisy Mello de Pinto, Anali Martegani Ferreira, Elisiane do Nascimento Rocha, Darlene Rosa Tambara, Julia Torres Cavalheiro, Michele Bulhosa de Souza, Josefine Busanello, Alessandra Porto d'Avila, Helena Becker Issi

DOI: $10.36229 / 978-65-5866-138-2 . C A P .16$

Autores: 


\section{Capítulo 1}

\section{Tensão do papel de cuidador em familiares de idosos: Compreensão à luz da revisão integrativa da literatura}

\section{Lara de Sá Neves Loureiro \\ Maria Auxiliadora Pereira \\ Maria das Graças Melo Fernandes}

Resumo: Estudo descritivo que tem como objetivo identificar, por meio de uma revisão integrativa da literatura, o conhecimento científico acerca da conceptualização do fenômeno da tensão do papel do cuidador. Para esta revisão foram selecionados 6 artigos que atenderam aos seguintes critérios: publicados na íntegra, nos idiomas português, inglês e espanhol, entre os anos de 2009 e 2014 e que contemplasse elementos que conduzissem à conceptualização do fenômeno da tensão do papel do cuidador em cuidadores familiares de idosos. Quanto ao país de origem dos autores, houve predomínio de estudos desenvolvidos por norteamericanos $(33,3 \%)$ e canadenses $(33,3 \%)$, seguidos por brasileiros $(16,6 \%)$ e ingleses $(16,6 \%)$. Com relação a área de conhecimento dos pesquisadores, dois estudos não especificaram, observando predomínio na área de medicina (33,3\%), seguido das áreas de enfermagem $(16,6 \%)$ e psicologia $(16,6 \%)$. No que concerne ao nível de evidência dos estudos, os seis artigos pesquisados foram classificados no nível 6 , relacionado às pesquisas descritivas ou qualitativas. 0 conhecimento produzido revelou a complexidade do fenômeno Tensão do papel de cuidador ao assinalar aspectos negativos, multifatoriais e dinâmicos relacionados aos efeitos da provisão de cuidados sobre a vida do cuidador, o que pode contribui para que, por vezes, a identificação dessa relevante problemática seja negligenciada pelos profissionais de saúde, familiares e pela sociedade. Ademais, pode-se inferir que os termos sobrecarga e tensão do papel de cuidador, embora frequentemente utilizados como sinônimos, apresentam diferentes significados, uma vez que a sobrecarga do cuidador reflete uma demanda externa e holística, relacionada aos aspectos físicos, emocionais, sociais e financeiros do processo de dispensar cuidados, ao passo que a tensão do papel do cuidador refere-se a um constructo mais complexo, que envolve a resposta do cuidador, como o estresse, por exemplo, ao se expor aos aspectos negativos relacionados à provisão de cuidados. Conclui-se que a tensão do papel de cuidador compreende um fenômeno multifacetado que envolve desequilíbrio e/ou impacto negativo nas dimensões física, psicológica, social e econômica do cuidador e que a elucidação da sua conceptualização contribui para o seu uso na prática clínica, subsidiando o planejamento e implementação de uma assistência qualificada que vise minimizar os impactos negativos oriundos da situação de cuidado.

Palavras-chave: Cuidadores, idosos, tensão. 


\section{INTRODUÇÃO}

O cuidado ao idoso dependente pode ser implementado tanto pelos profissionais e instituições de saúde quanto pela família e/ou voluntários, utilizando-se os termos formal e informal para indicar o tipo de apoio oferecido. A respeito disso, designa-se cuidador formal o profissional contratado, remunerado e capacitado, que presta assistência ao idoso e/ou à sua família. Denomina-se cuidador informal ou cuidador familiar, por sua vez, um membro da família, amigos, vizinhos ou voluntários sem formação específica, que proporcionam cuidados não remunerados ao ente dependente (MARQUES et al., 2011).

No contexto brasileiro, evidencia-se carência de investimentos direcionados à atenção à saúde dos idosos, em especial, aos cuidados de longa duração, sendo a família a principal fonte de recursos disponíveis para o sustento e para o cuidado do idoso dependente. Assim, na ocasião de algum evento que comprometa a funcionalidade do idoso, é a família, na figura do cuidador familiar, que, prioritariamente, tem se responsabilizado pelo cuidado do idoso, assumindo essa função, de modo geral, como um processo natural e inerente ao papel da vida, em que, muitas vezes, não há questionamentos sobre o desejo, a disponibilidade e o preparo para prover os cuidados necessários (GUIMARÃES; LIPP, 2011).

Nesse cenário, as famílias que têm entre seus membros um idoso dependente vivenciam, juntamente com ele, toda a problemática que envolve a questão e assumem desafios ligados ao desempenho de novos papéis, como trabalhar com as perdas de atividades sociais e financeiras, além de lidar com seus desgastes físicos, contribuindo para o acometimento de efeitos deletérios, dentre os quais a sobrecarga e a tensão do papel de cuidador, termos frequentemente utilizados como sinônimos para designar o impacto negativo das demandas da situação de cuidado para o cuidador (FERNANDES; GARCIA, 2010; LOUREIRO et al, 2013).

Tendo em vista que ainda existem significativas lacunas no que concerne à conceptualização do fenômeno da tensão do papel de cuidador, bem como sua diferenciação de outros termos com significados similares, e que a clarificação desse conceito contribui para o seu uso na prática clínica, subsidiando o planejamento e a implementação de uma assistência de enfermagem individualizada e sistemática para o cuidador, com abrangência, inclusive, de ações de cunho preventivo, o presente estudo tem como objetivo identificar, por meio de uma revisão integrativa da literatura, a conceptualização do fenômeno da tensão do papel do cuidador.

\section{METODOLOGIA}

Estudo descritivo, efetivado por meio de uma revisão integrativa da literatura, que teve como propósito responder à seguinte questão norteadora: qual o conhecimento científico produzido sobre a conceptualização Tensão do papel de cuidador? Ademais, salienta-se que o estudo foi operacionalizado em seis etapas: delimitação da questão de pesquisa; estabelecimento de critérios para inclusão de estudos/amostragem ou busca na literatura; definição das informações a serem extraídas dos estudos; avaliação dos estudos; interpretação dos resultados; e apresentação da síntese do conhecimento.

As estratégias de busca do corpus literário tiveram a finalidade de localizar, por meio do site da Biblioteca Virtual em Saúde (BVS), estudos publicados nas bases de dados Latino-americana e do Caribe em Ciências da Saúde (LILACS), Medical Literature Analysis and Retrieval System Online (MEDILINE) e Cumulative Index to Nursing and Allied Health Literature (CINAHL), no período de fevereiro a março de 2014, sendo utilizados os seguintes termos: tensão (strain); tensão do cuidador (caregiver strain; tensión de cuidador); tensão do papel de cuidador (caregiver role strain; tensión de rol cuidador); sobrecarga do cuidador (caregiver burden; la carga del cuidador) e estresse do cuidador (caregiver stress; el estrés del cuidador). A busca da literatura partindo dos termos "tensão", "estresse", "sobrecarga", "fardo", "strain", "stress", "burden", "caregiver strain", "caregiver role strain", "caregiver stress" e "caregiver burden" foi realizada por se verificar que essas expressões têm sido utilizadas como sinônimas pelas literaturas nacional e internacional, para nomear as consequências relativas ao ônus de prover cuidados.

Para compor o corpus literário, foram adotados os seguintes critérios de inclusão: disponibilidade do artigo na íntegra, publicado entre os anos de 2009 e 2014, nos idiomas português, inglês ou espanhol, e que contemplasse elementos que conduzissem à conceptualização do fenômeno da tensão do papel do cuidador em cuidadores familiares de idosos. Além disso, foram utilizados dois testes de refinamento para selecionar os estudos que deveriam ser incluídos na amostra: o teste de rastreamento I, aplicado aos títulos e aos resumos, e o teste de rastreamento II, aplicado aos artigos lidos na íntegra. No primeiro momento da busca nas bases de dados mencionadas, foram identificados 3.210 artigos, que foram submetidos ao teste de rastreamento I, o qual possibilitou a leitura e a análise cuidadosa dos títulos e dos 
resumos, com o intuito de verificar se abordavam, de alguma forma, os elementos essenciais para a análise conceptual pretendida. Com essa triagem inicial, foi possível excluir 3.116 artigos, por não atenderem aos critérios de inclusão, duplicação de artigos e indisponibilidade de acesso na íntegra.

No segundo momento, procedeu-se à leitura criteriosa dos artigos na íntegra por dois pesquisadores, de maneira independente, e aplicou-se o teste de rastreamento II, em que foram considerados os critérios de pertinência e consistência do conteúdo, com vistas a identificar materiais com enfoque na definição teórica da tensão do papel do cuidador em cuidadores familiares de idosos. Após isso, foram excluídos da amostra 78 artigos, sendo a amostra final composta por 6 artigos.

Depois de delimitar a amostra, foi feita uma leitura criteriosa dos materiais, destacando-se os fragmentos ou unidades de análise - frases, temas, expressões, parágrafos - que correspondiam aos elementos constituintes e que eram relacionados ao conceito em processo de análise. Para o alcance desse propósito e a categorização dos estudos selecionados, foi utilizado um instrumento de coleta de dados que abrangeu as seguintes variáveis: ano de publicação, país de origem, área de conhecimento, nível de evidência a síntese do conhecimento produzido. Para a definição do nível de evidência dos artigos, foi utilizada a seguinte classificação (MELNYK; FINEOUT-OVERHOLT, 2005): nível um: revisão sistemática ou metanálise de todos os relevantes ensaios clínicos randomizados controlados; nível dois: Ensaio clínico randomizado controlado bem delineado; nível três: Ensaios clínicos bem delineados sem randomização; nível quatro: Estudo de coorte e de caso de controle bem delineados; nível cinco: Revisão sistemática de estudos descritivos e qualitativos; nível seis: Estudo descritivo ou qualitativo; nível 7: Opinião de autoridades e/ou relatório de comitês de especialistas.

\section{RESULTADOS}

Da totalidade da amostra selecionada, 2 (33,3\%) artigos foram publicados no ano de 2010 e os quatro restantes tiveram sua publicação efetivada nos anos de: 2009, 2011, 2012 e 2014. Quanto ao país de origem dos pesquisadores, observou-se maior prevalência de estudos desenvolvidos por autores norte americanos $(2 ; 33,3 \%)$ e canadenses $(2 ; 33,3 \%)$, seguido por brasileiros $(1 ; 16,6 \%)$ e ingleses $(1 ; 16,6 \%)$. No âmbito da área de conhecimento, 2 (33,3\%) estudos não especificaram a área de conhecimento do autor, 2 (33,3) inseriram-se na área de medicina, 1 (16,6\%) na área da enfermagem e $1(33,3)$, na área de psicologia. Quanto ao nível de evidência do estudo, evidenciou-se que todos os artigos foram classificados em nível 6, tratando, pois, de pesquisas descritivas ou qualitativas.

No concernente à síntese do conhecimento produzido pelos estudos analisados, o Quadro 1 expressa os resultados referentes às definições teóricas do fenômeno da tensão do papel de cuidador elucidadas na literatura pesquisada.

Quadro 1 - Definições do conceito 'Tensão do papel de cuidador' evidenciadas na literatura. João Pessoa PB, 2016.

\section{Definição}

O estado alterado de bem-estar do cuidador e a sua percepção em suportar dificuldades relacionadas à provisão de cuidados (DUXBURY, HIGGINS, SMART, 2011, P. 128).

Combinação de estresse e sobrecarga, que acarreta consequência sobre a saúde dos cuidadores de indivíduos dependentes (PRINCEL et al., 2012, p. 63).

Impactos emocionais, físicos e sociais negativos na vida do cuidador (VAUGHAN et al., 2014, p. 538).

Constructo multidimensional que se refere às consequências duradouras do ônus da prestação de cuidados percebida pelo cuidador que afetam o seu bem-estar (BAINBRIDGE et al., 2009, p. 508).

Dificuldade experimentada no cumprimento do papel de cuidar de um ente dependente (CARTER et al., 2010, p. 726).

Estado dinâmico de alteração do bem-estar biopsicossocial do cuidador familiar, variável de pessoa para pessoa, multideterminado e cumulativo, resultante do processo de cuidar de um parente incapacitado (FERNANDES; GARCIA, 2010, P. 28). 


\section{DISCUSSÃO}

A palavra tensão apresenta uma variedade de significados. É definida como "estado do que é ou se apresenta tenso"; "estado em que há retesamento, ou sensação de retesamento, de certos músculos, ou em que se é levado além de um limite normal de emoção (medicina)"; "diferença de potencial elétrico entre dois pontos de um circuito; tensão elétrica; voltagem (eletricidade)"; "desacordo nas relações entre países, classes sociais ou partidos políticos"; "estado ou sensação de apreensão, de incerteza" (tensão emocional) (FERREIRA, 2010). Conforme se verifica nessa assertiva, o termo tensão é aplicado em diferentes áreas do conhecimento.

Na busca pela concepção do termo nos Descritores em Ciências da Saúde (DeCS), que reúne um vocabulário estruturado e trilíngue que serve como uma linguagem única na indexação de artigos científicos, livros, entre outros tipos de materiais, também se constataram uma variedade de significados para o termo tensão e o uso de várias expressões que compreendem conceitos relacionados, porém são usados como sinônimos de tensão, tais como: estresse da vida, estresse relacionado a aspecto da vida, angústia, estresse emocional, tensão vital, tensão da vida, sofrimento psíquico, sofrimento mental. Este último é definido como um quadro mórbido característico, de natureza basicamente psíquica, sem causas orgânicas que possam ser evidenciadas pelos meios usuais de exame médico e que só aparecem em condições especiais, de trabalho ou de guerra (DESCSa, 2014).

No concernente ao termo 'papel', também presente no conceito sob análise, é compreendido como "atuação, desempenho, emprego, função e uso" (FERREIRA, 2010) e como o padrão de comportamento conhecido e característico, exibido por um indivíduo como membro de um grupo social particular, que interage conforme um conjunto de expectativas implícitas e explícitas, regras e padrões de comportamento esperados pelos outros (DESCSb, 2014; GARCIA, 2014).

Já o termo cuidador refere-se àquele que cuida; que é zeloso (FERREIRA, 2010). Os cuidadores são definidos pelo DeCS como as pessoas que proveem cuidados para aqueles que precisam de supervisão ou assistência por causa da presença de doença ou incapacidade (DESCSc, 2014). De acordo com a Política Nacional de Saúde da Pessoa Idosa, o cuidador é a pessoa, membro ou não da família, que, com ou sem remuneração, cuida do idoso doente ou dependente no exercício de suas atividades de vida diárias, tais como alimentação, higiene pessoal, medicação de rotina, acompanhamento aos serviços de saúde e de outros serviços que requeiram no cotidiano, excluídas as técnicas ou procedimentos identificados com profissões legalmente estabelecidas, particularmente na área de Enfermagem (BRASIL, 1994).

Esses termos expressam nominalmente o conceito 'Tensão do papel de cuidador' o qual conforme evidenciado na literatura pesquisada, faz referência, de modo geral, ao desequilíbrio e/ou impacto negativo nas dimensões física, psicológica, social e econômica do cuidador, que podem ser mutáveis, a depender de diversas condições que permeiam a relação de cuidado (cuidador versus receptor de cuidado) e do ambiente físico e simbólico onde a ação cuidativa acontece.

A "Tensão do papel de cuidador" é também referida como uma dificuldade experimentada no cumprimento do papel de cuidar de um ente dependente (CARTER et al., 2010). Tal assertiva se assemelha à definição do conceito diagnóstico, apresentado pelo Sistema de Classificação de diagnósticos de enfermagem da NANDA-I (2015, p. 128): "dificuldade para desempenhar o papel do cuidador da família ou de outras pessoas significativas". Convém salientar que essas definições parecem insuficientes para delimitar precisamente o fenômeno, uma vez que não contempla toda a sua dimensão objetiva e subjetiva.

Cumpre assinalar outra definição conceitual apontada pela literatura que considera a tensão do papel do cuidador como uma combinação de estresse e sobrecarga (PRINCEL et al., 2012). Isso ocorre, em especial, em virtude de esses termos ("tensão", "estresse" e "sobrecarga") serem usados como sinônimos para descrever as consequências duradouras do ônus da provisão de cuidados no bem-estar dos cuidadores (FERNANDES; GARCIA, 2010; BAINBRIDGE et al., 2009). A compreensão de Hunt (2003) do fenômeno da tensão do cuidador como a sobrecarga física, emocional, social e/ou financeira que ele experimenta no processo de dispensar cuidados pode contribuir para confusão de significação dos fenômenos "tensão" e "sobrecarga".

Sobre esse aspecto, convém ressaltar que a sobrecarga do cuidador reflete uma demanda externa e holística, relacionada aos aspectos físicos, emocionais, sociais e financeiros do processo de dispensar cuidados (HUNT, 2003), ao passo que a tensão do papel do cuidador refere-se a um constructo mais complexo, que envolve a resposta do cuidador, como o estresse, por exemplo, ao se expor aos aspectos negativos relacionados à provisão de cuidados (BAINBRIDGE et al., 2009). Isso significa dizer que os cuidadores podem experimentar níveis semelhantes de sobrecarga em situações de cuidado parecidas, 
entretanto reagir de maneiras diferentes. No decorrer do tempo, o estresse e a sobrecarga relacionados à provisão diária de cuidados favorecem a tensão do cuidador, a qual deteriora sua saúde e acarreta problemas físicos, psicológicos e sociais. Considerando o exposto, na literatura pesquisada, é possível inferir que a sobrecarga diz respeito a um fator antecedente da tensão, enquanto o estresse é um atributo essencial desse fenômeno.

\section{CONCLUSÃO}

As definições apontadas pela literatura estudada salientam a complexidade do fenômeno 'Tensão do papel de cuidador' ao assinalar aspectos negativos, multifatoriais e dinâmicos relacionados aos efeitos da provisão de cuidados sobre a vida do cuidador. Diante da realidade em que se insere o papel dos cuidadores, que compartilha de pouca visibilidade e valorização, é preciso reconhecer suas vivências, suas dificuldades e seus sentimentos, para compreender o processo de cuidar na perspectiva do cuidador, com vistas ao planejamento e implementação de intervenções específicas que visem minimizar os impactos negativos oriundos da situação de cuidado.

Nesse cenário, o desenvolvimento de estudos que têm como propósito avigorar os efeitos decorrentes da provisão de cuidado na vida do cuidador, por meio da clarificação de sua conceptualização, como este, ressalva a relevância de que a atenção à saúde não deva se restringir apenas ao idoso ou ao ente dependente, mas também se amplie para atender às necessidades dos cuidadores familiares, cujo foco não é só a capacitação do seu papel com estratégias educativas, mas também a atenção às suas necessidades pessoais de cuidados.

\section{REFERÊNCIAS}

[1]. BAINBRIDGE, D.; KRUEGER, P.; LOHFELD, L.; BRAZIL, K. Stress processes in caring for an end-of-life family member: application of a theoretical model., v.13, n.4, p. 537-45, 2009.

[2]. BRASIL. Lei No 8.842 de 4 de janeiro de 1994. Dispõe sobre a política nacional do idoso, cria o Conselho Nacional do Idoso e dá outras providências [acesso em Junho de 2014]. Disponível em: <http://www.planalto.gov.br/ccivil_03/leis/l8842.htm>.

[3]. CARTER, J.H.; LYONS, K.S.; STEWART, B.J., et al. Does age make a difference in caregiver strain? Comparison of young versus older caregivers in early-stage Parkinson's disease. Mov Disord, v.25, n.6, p. 724-30, .2010.

[4]. DeCSa. Base de dados na internet. São Paulo: BIREME Biblioteca Virtual em Saúde, 2014. Tensão, número de registro: 13703. [acesso em: Julho de 2014]. Disponível em: <http://decs.bvs.br/cgi-bin/wxis1660.exe/decsserver/>.

[5]. DeCSb. Base de dados na internet. São Paulo: BIREME Biblioteca Virtual em Saúde, 2014. Papel, número de registro: 12755. [acesso em: Julho de 2014]. Disponível em: <http://decs.bvs.br/cgi-bin/wxis1660.exe/decsserver/>.

[6]. DeCSc. Base de dados na internet. São Paulo: BIREME Biblioteca Virtual em Saúde, 2014. Cuidadores, número de registro: 30212. [acesso em: Julho de 2014]. Disponível em: <http://decs.bvs.br/cgibin/wxis1660.exe/decsserver/>.

[7]. DUXBURY, L.; HIGGINS, C.; SMART, R. Elder care and the impact of caregiver strain on the health of employed caregivers. Work. V.40, n.1, p. 29-36, 2011.

[8]. FERNANDES, M.G.M; GARCIA, T.R. Efeitos da provisão de cuidados sobre o cuidador familiar: uma análise conceitual. Revista Enfermagem Atual, v. 55, p. 23-28, 2010.

[9]. FERREIRA, A.B.H. Mini Aurélio: o dicionário da língua portuguesa. 8 ed. Curitiba: Positivo, 2010.

[10]. GARCIA TR (org.). Classificação Internacional para a prática de Enfermagem CIPE®: aplicação à realidade brasileira. Porto Alegre: Artmed, 2014.

[11]. GUIMARÃES, C.A; LIPP, M.E.N. Um olhar sobre o cuidador de pacientes oncológicos recebendo cuidados paliativos. Psicologia: Teoria e Prática, v.13, n.2, p.50-62, 2011.

[12]. HUNT, C.K. Concepts in Caregiver Research. Journal of Nursing Scholarship, v.35, n.1, p. 27-32, 2003.

[13]. LOUREIRO, L.S.N.; FERNANDES, M.G.M.; MARQUES, S.; NÓBREGA, M.M.L.; RODRIGUES, R.A.P. Sobrecarga de cuidadores familiares de idosos: prevalência e associação com características do idoso e do cuidador. Rev Esc Enferm USP, v.47, n.5, p. 1129-36, 2013.

[14]. MARQUES, A.K.M.C.; LANDIM, F.L.P.; COLLARES, P.M.; MESQUITA, R.B. Apoio social na experiência do familiar cuidador. Ciênc. saúde coletiva, v.16, n.1, p. 945-55, 2011. 
[15]. MELNYK, B.M.; FINEOUT-OVERHOLT, E. Making the case for evidence-based practice. In: MELNYK, B.M.; FINEOUT-OVERHOLT, E. Evidence-based practice in nursing \& healthcare. A guide to best practice. Philadelphia: Lippincot Williams \& Wilkins; 2005.

[16]. PRINCE1, M.; BRODATY, H.; UWAKWE, R, et al. Strain and its correlates among carers of people with dementia in low-income and middle-income countries. A 10/66 Dementia Research Group population-based survey. Int J Geriatr Psychiatry, v. 27, p. 670-82, 2012.

[17]. VAUGHAN, E.L.; FEINN, R.; BERNARD, S., et al. Relationships Between Child Emotional and Behavioral Symptoms and Caregiver Strain and Parenting Stress. Journal of Health and Social Behavior, v.55, p. 91-106, 2014. 


\section{Capítulo 2}

O cuidador e suas práticas em saúde: Interações e influências na adesão ao tratamento odontológico entre adolescentes

Jaqueline Vilela Bulgareli

Luciane Miranda Guerra

Camila Gonçalo Mialhe

Brunna Verna Castro Gondinho

Alcir José de Oliveira Júnior

Marcelo de Castro Meneghim

Sílvia Letícia Freddo

Karine Laura Cortelazzi Mendes

Antonio Carlos Pereira

RESUMO: 0 objetivo do estudo foi analisar os significados atribuídos pelos cuidadores de uma população adolescente sobre o cuidado em saúde e as interações e influências deste cenário com a adesão dos adolescentes ao tratamento odontológico. Esta investigação qualitativa refere-se a uma pesquisa em indivíduos, com idade entre 15 e 19 anos, que pertencem à área que envolve 34 Unidades de Saúde da Família no município de Piracicaba, São Paulo, Brasil, no ano de 2015. Foram realizadas 24 entrevistas, com roteiro semiestruturado. A análise de temática do conteúdo foi adotada e identificaram-se 7 temas referentes aos cuidados que o cuidador presta aos adolescentes, seu comportamento em saúde e a influência deste na adesão ao tratamento odontológico, sendo estes: qualidade da alimentação e do sono, cuidados no preparo dos alimentos, cuidados médicos e odontológicos de saúde (consultas e medicamentos), limpeza do corpo e dentes, limpeza e organização da casa, fiscalização ao cumprimento de "regras saudáveis" e cumprimento/descumprimento de "regras saudáveis". Estes temas foram agrupados configurando a construção de 02 eixos temáticos: "regras saudáveis na perspectiva do cuidador" e "regras saudáveis na perspectiva do cuidador em relação ao indivíduo que recebe o cuidado". Conclui-se que a perspectiva de "cuidado em saúde" dos entrevistados, descarta fatores macrossociais e considera a limpeza como sinônimo deste tipo de cuidado e desconsidera outros comportamentos de risco relacionados às doenças, inclusive bucais, que acometem os adolescentes. Esses aspectos podem estar interagindo e influenciando os filhos nas decisões com relação à prevenção e adesão ao tratamento de doenças bucais.

Palavras-chave: Saúde Bucal, Promoção da Saúde, Pesquisa Qualitativa, Comportamento do Adolescente. 


\section{INTRODUÇÃO}

A adolescência é um período de transição no qual os jovens enfrentam mudanças nos sistemas emocional, cognitivo e comportamental [1], marcada por dificuldades, principalmente, em relação aos conflitos com a família, os pares e a escola [2].

Sabe-se que a família exerce papel importante no ato do cuidar (cuidado), sendo este não somente algo que se dá a outro, e sim algo que se exerce e se cria com o outro, numa atmosfera de afetos [3]. Baseado neste conceito é importante saber que o cuidado familiar para com o adolescente apresenta diferença em função de alguns aspectos. Podem ser citados, por exemplo, o contexto da vulnerabilidade social no qual o jovem se encontra inserido; a percepção do sujeito e da família em relação ao cuidado em saúde, de seus valores culturais; suas experiências com serviços odontológicos; conhecimentos e atitudes obtidos no contato com profissionais da área, professores de escola e meios de comunicação.

No aspecto familiar, considera-se que a ausência de responsividade das figuras cuidadoras intervém nas relações interpessoais na adolescência [4]. Portanto, a família pode se configurar como condição de risco ou de proteção ao adolescente, e isto dependerá da qualidade das relações que se estabelecem nesse ambiente [5].

Diversos estudos ressaltam a necessidade de incluir a família no atendimento e no contexto que o adolescente faz parte (amigos, escola e comunidade), a fim de favorecer os padrões de relação entre esses agentes sociais [6].

A literatura revela que dentre outros aspectos, a rede de apoio social e familiar está relacionada ao fenômeno da adesão [7]. O termo adesão ao tratamento pode ser associado a diversos comportamentos inerentes à saúde. Referem-se ao seguimento prescritivo de medicamentos, aspectos referentes ao sistema de saúde, fatores socioeconômicos, ao tratamento do paciente e à própria doença. A Organização Mundial da Saúde (OMS) conceitua a adesão ao tratamento de doenças crônicas como sendo a medida com que o comportamento de uma pessoa corresponde às recomendações de um profissional de saúde [8]. Alguns autores dizem que a adesão é um processo comportamental complexo influenciado pelo meio que o indivíduo vive, pelos profissionais de saúde e pelos cuidados assistenciais [9].

Deste modo, o conceito de adesão supera a visão simplista e limitada da assistência e pressupõe uma parceria entre quem cuida e quem é cuidado. Esta perspectiva considera o cuidado com o indivíduo como ponto central para uma intervenção participativa e acompanhamento do processo saúde doença do sujeito [10].

Diante disso, pouco se sabe sobre os cuidados em saúde na vivência do cuidador e suas influências na adesão ao tratamento em saúde oral dos adolescentes. Além disso, muitas vezes o próprio cuidador desconhece que a atitude e a prática em saúde podem ou não ser adequados para os adolescentes, influenciando suas decisões em relação ao tratamento odontológico. Assim, o objetivo deste estudo foi analisar os significados atribuídos pelos cuidadores de uma população adolescente sobre o cuidado em saúde e as prováveis interações e influências deste cenário com a adesão dos adolescentes ao tratamento odontológico.

\section{METODOLOGIA}

Esta pesquisa refere-se a uma investigação qualitativa de adolescentes, com idade entre 15 e 19 anos, que pertencem à 34 Unidades de Saúde da Família no município de Piracicaba, São Paulo, Brasil, no período de 2015. A execução do trabalho teve prévia aprovação junto ao comitê de ética (CEP- FOP/Unicamp) com o n. $027 / 2011$.

Na etapa anterior da pesquisa, realizada em 2013 e 2014, foi coletado os dados quantitativos (cárie dentária e/ou doença periodontal, de acordo com os critérios da OMS, 1999 [11]. Os participantes com necessidade de tratamento odontológico (presença de cárie e/ou doença periodontal) foram orientados a agendar consulta na própria unidade de saúde para realizar o tratamento [12].

Após um ano e oito meses da coleta inicial, os pesquisadores retornaram nas Unidades de Saúde, a fim de identificar quais adolescentes aderiram ao tratamento odontológico recomendado. Para saber se o adolescente aderiu ou não ao tratamento, foi realizado um novo exame nas mesmas condições clínicas e com os mesmos examinadores. Aqueles que eventualmente não procuraram o atendimento ou até chegaram a procurar, mas não concluíram o tratamento foram considerados como pacientes não aderentes. 
Diante do cenário encontrado de adesão e não adesão ao tratamento surgiu o interesse dos pesquisadores em incluir uma etapa qualitativa neste estudo, para investigar as ações/práticas de saúde oferecidas pelos cuidadores no ambiente familiar e sua relação com a adesão/não adesão ao tratamento odontológico dos adolescentes participantes do estudo. Optou-se pela realização de uma pesquisa qualitativa, uma vez que esta metodologia relaciona tanto os significados que os indivíduos atribuem às suas experiências do mundo social, quanto aos modos como os mesmos compreendem este mundo, tentando interpretar os fenômenos sociais (interações, comportamentos, etc.) em termos dos sentidos que as pessoas lhes dão [13].

Quanto à forma de coleta dos discursos, foi aplicada a entrevista semidirigida, que tem como particularidades questões básicas apoiadas em teorias e hipóteses relacionadas ao tema da pesquisa que, por conseguinte, traz novas teorias e perguntas a partir das respostas dos participantes. Além disso, mantém a presença atuante do pesquisador no processo de coleta de informações [14].

Para a realização das entrevistas com os cuidadores dos adolescentes, utilizou-se um roteiro semidirigido. Neste contexto, o presente artigo refere-se a análise e discussão da seguinte questão norteadora: "Quais os cuidados que a senhora/senhor toma em relação à saúde de seu filho?".

A coleta dos dados qualitativos teve início em maio de 2015. Foi realizado o pré-teste, previamente ao início da fase de coleta, a fim de verificar a clareza e veracidade das perguntas e respostas, testar o método de entrevista e corrigir possíveis distorções e problemas relacionados aos métodos.

A equipe de pesquisadores contatou por telefone os responsáveis pelo adolescente, abordando a possibilidade de realizar a entrevista em domicílio. Então, foi combinando entre o pesquisador e o entrevistado, o horário e dia mais adequado e procedeu-se o agendamento e condução das entrevistas junto à família do adolescente.

O número de entrevistados foi definido pela saturação do discurso, ou seja, quando nenhuma nova informação significativa para a compreensão do fenômeno investigado foi acrescentada durante as entrevistas [15]. Dois pesquisadores realizaram a transcrição das falas imediatamente após as entrevistas com os participantes, mantendo a fidelidade dos discursos.

A análise de conteúdo temática foi conduzida de acordo com a trajetória de análise descrita por Gomes (2010) [16]. A etapa inicial consistiu na leitura exaustiva do material transcrito, correspondente a 24 entrevistas, com a finalidade de identificar um conjunto inicial de temas.

Posteriormente, os dados foram agrupados segundo os eixos emergentes do texto, e na sequência foram estabelecidos os agrupamentos e as conexões dos dados em seus respectivos eixos.

Após o refinamento dos eixos e sub eixos estabelecidos, tornou-se possível a identificação dos temas principais.

A identificação desses temas permitiu que os mesmos fossem distribuídos em quadros e, em seguida, foi elaborada uma redação por temas com o objetivo de contemplar os sentidos dos textos e sua articulação com os conceitos teóricos que orientaram esta análise. Deste modo, a análise temática, consistiu no agrupamento dos dados por temas e exame de todos os casos no estudo para certificação de que todas as manifestações de cada tema foram incluídas e analisadas. Por fim, resultou a redação final da análise, construindo o diálogo entre os temas, objetivos e questionamentos específicos do estudo.

\section{RESULTADOS E DISCUSSÃO}

0 universo do estudo caracteriza-se por 24 cuidadores responsáveis pelos adolescentes, dentre eles, mãe, pai, avós; sendo estes entrevistados no próprio domicílio.

$\mathrm{Na}$ análise temática das 24 entrevistas identificaram-se 7 temas referentes aos cuidados que o cuidador presta aos adolescentes, seu comportamento em saúde e a influência deste na adesão ao tratamento odontológico, sendo estas: 1. qualidade da alimentação e do sono, 2. cuidados no preparo dos alimentos, 3. cuidados médicos e odontológicos de saúde (consultas e medicamentos), 4. limpeza do corpo e dentes, 5. limpeza e organização da casa, 6. fiscalização ao cumprimento de "regras saudáveis", 7. cumprimento/descumprimento de "regras saudáveis".

Estes temas foram agrupados configurando a construção de 02 eixos temáticos: "regras saudáveis na perspectiva do cuidador" e "regras saudáveis na perspectiva do cuidador em relação ao indivíduo que recebe 


\section{1ํㅡㄹ Eixo: regras saudáveis na perspectiva do cuidador}

O sentido de regras saudáveis foi atribuído de acordo com o referencial teórico do conceito 'moderno' de promoção da saúde fomentado pela OMS. Este conceito surgiu a partir da década de 1980 e considera a Promoção da Saúde como sendo um conjunto de valores, tais como solidariedade, equidade, democracia, cidadania, participação, parceria, entre outros, bem como uma combinação de estratégias de ação que visam impactar nos determinantes sociais e comportamentais da saúde [17].

A definição atual de Promoção a Saúde está relacionada ao conceito ampliado de saúde definido na $8^{\underline{a}}$ Conferência Nacional de Saúde, que enfatiza como prioridade, a atuação nos fatores determinantes da saúde tais como: alimentação, a moradia, o saneamento básico, o meio ambiente, o trabalho, a renda, a educação, o transporte, o lazer e o acesso aos bens e serviços essenciais, garantindo as pessoas e à coletividade condições de bem estar físico, mental e social [18].

Já a Carta de Ottawa define promoção da saúde como o "Processo de capacitação da comunidade para atuar na melhoria da sua qualidade de vida e saúde, incluindo uma maior participação no controle deste processo" [18]. Este conceito valoriza a necessidade das pessoas em saber lidar com os vários fatores que determinam sua saúde e não apenas considera o aspecto do bem-estar físico, priorizado nos sistemas tradicionais de assistência em saúde.

No eixo temático do cuidador constatou-se que os participantes da pesquisa consideram o "cumprir regras" relacionados à limpeza e alimentação saudável, como mais importante determinante do processo saúde doença.

\section{P: Quais os cuidados que a senhora toma em relação à saúde de seu filho?}

R6: É cuidar bem da casa, da comida também, não ficar comendo muita gordura, fritura. Eu procuro fazer tudo fresquinho. Deixar tudo limpo, abrir bem as janelas para entrar ar (E6, mãe de adolescente).

R4: Eu gosto de deixar tudo certinho!! Lavo bem as verduras, os legumes (...) as roupas de cama também, toalha de banho, tiro sempre pra lavar. A Josiane escova sempre, não tem que me preocupar, mas o mais novo preciso ficar em cima (E4, mãe de adolescente).

Pela perspectiva do cumprimento de regras saudáveis por parte do cuidador, constata-se que a mãe pratica ações de cuidado para com o adolescente numa visão limitada de promoção da saúde baseada mais nas medidas adotadas no conceito teórico de Leavell e Clark (1976) [19]. Essas medidas incluem, dentre vários fatores, aqueles relacionados a bom padrão de nutrição, moradia adequada, condições agradáveis no lar e ao aconselhamento do profissional de saúde no tratamento da doença e na prevenção de complicações. Para Buss (2009) [20], esta visão apresenta certos limites centrados no indivíduo, com uma projeção para a família ou grupos.

Embora o modelo de Leavell e Clarck seja o mais divulgado para os serviços de saúde e trate a promoção como um dos estágios dos 3 níveis de prevenção, um outro modelo muito utilizado é o esquema quadridimensional de Lalonde (1981) [21], que considera os determinantes da situação de saúde de uma população: o estilo de vida; a biologia humana; o ambiente e os serviços de saúde.

Em outro extrato, verifica-se que há também a "fiscalização" do cumprimento de regras saudáveis por parte do cuidador, ainda relacionados à limpeza, principalmente da casa, corpo e dos dentes. Esta visão representa o sentido que os respondentes possuem a respeito do "cuidar em saúde". Para eles, a limpeza é sinônimo de "cuidado", pois precisa estar sempre tudo limpo, a casa, o corpo e inclusive os dentes dos filhos que são considerados uma extensão do processo de "limpar" desta família:

R8: Aqui tem que ser bem limpinho, bem certinho. Precisa lavar a mão, eles não gostam, mas eu faço lavar as mãos. (?) O mais velho eu não me preocupo muito, mas com pequeno, fico em cima. Se eu tivesse tratado, não tinha que tirar todos os meus dentes. Em cada gestação tirava 2 dentes. Ficava com dor e tinha que tirar. Então pego no pé mesmo (E8, mãe de adolescente).

Corroborando com este achado, estudos anteriores investigaram os significados de "saúde bucal" e do "cuidado odontológico" com as mães e estas associaram o adoecimento bucal às normas de higiene e dietéticas, tais como escovação (três vezes ao dia), ingestão de alimentos, utilização do fio dental, ausência de cárie, ausência de mau hálito e a ida ao dentista. Ou seja, no presente estudo e nos estudos de Mendonça (2001) [22] e Domingues (2008) [23] o significado de saúde bucal está mais relacionado com a atividade de cuidar do corpo do que com a situação de saúde das pessoas.

Sabe-se que o cumprimento e a fiscalização de regras saudáveis não garantem o aprendizado e a incorporação de novas práticas entre os indivíduos, principalmente os adolescentes. 
A Teoria Social Cognitiva desenvolvida por Bandura (2008) [24] sustenta a hipótese observada no estudo, e diz que ao pesquisar sobre o comportamento humano, o homem não é visto como um ser passivo dominado e influenciado pelas ações ambientais, mas sim como um sujeito ativo em todos os processos. Por conseguinte, o homem aprende e adquire experiências observando as consequências dentro do seu ambiente, assim como as vivências das pessoas aos quais convive.

Realizar atos mecânicos de limpeza dentária e ser fiscalizado por esta tarefa não previne nem trata os principais acometimentos bucais. A literatura revela que as afecções bucais, principalmente entre adolescentes, são decorrentes de fatores biológicos (biofilme, dieta, saliva) e macro (renda, educação, fatores comportamentais, conhecimento, escolaridade, atitudes e outros) [25]. Portanto, para um melhor planejamento, tanto individual como coletivo, o cirurgião dentista precisa atuar numa dimensão ampliada de fatores "extra bucais" que afetam o "intra bucal".

R27: Eu tento evitar doce, gordura, refrigerante, balas, chicletes, pego no pé por causa disso. Eu compro escova, pasta de dente, sempre troco a escova (E27, mãe de adolescente).

Sabe-se que os principais agravos bucais, como a cárie e a doença periodontal, são evitáveis a partir da identificação e intervenção dos fatores de risco pela equipe de saúde, pelo indivíduo e a família. Os fatores de risco fundamentais incluem não somente a escovação dentária deficiente, mas requerem a manutenção de condições de saúde bucal compatíveis com uma boa qualidade de vida.

Ressalta-se ainda, que a estética é um fator que atualmente é muito valorizada pelo adolescente. A conhecida "ortodontia de camelô" já é considerada uma prática comum nos adolescentes, na medida em que a ideia de pertencimento e de conquista da beleza é proporcionada pelo uso do aparelho ortodôntico. Um estudo recente confirma essa perspectiva, ao constatar que o uso de aparelhos ortodônticos se mostrou como potente estimulador do interesse e do estabelecimento de prioridades na atenção à saúde bucal entre os adolescentes [12]. Porém, a força ortodôntica excessiva prejudica a dentição e pode acarretar sérias consequências (retração e reabsorção) para o indivíduo, culminando, muitas vezes em perdas dentárias de elementos hígidos.

Diante destes fatores, o adolescente poderia adotar algumas atitudes e comportamentos que sejam compatíveis com o seu estado de saúde bucal e geral como a redução e prevenção do abuso de álcool e fumo; melhorias nas condições de higiene para controle das doenças mais prevalentes, através da escovação com dentifrício fluoretado e o uso do fio dental; alimentação saudável; entre outros. Além disso, é necessário procurar o cirurgião dentista para realizar o tratamento adequado para que a cura e a reabilitação aconteçam.

Em relação ao "não cumprem de regras saudáveis", verifica-se que os cuidadores não aplicam regras saudáveis ligadas principalmente aos cuidados médicos e odontológicos, alimentação e limpeza com os dentes. Portanto, verificou-se que os participantes da pesquisa apresentaram diferentes entendimentos do que seria o cuidado em saúde, postura esta, possivelmente reproduzida pelo adolescente influenciando-o na decisão de não aderir ao tratamento odontológico:

R21: Acho que sou um pouco descuidada, não tomo nenhuma medida, sou desencanada. Eu digo faz outra coisa que passa. Ai mãe tô com dor nas costas vai fazer outra coisa, distrair que passa. Não fique dando atenção pra dor que passa. E dá certo. Ninguém em casa adoece. Sempre falo para escovar os dentes, mas sou um pouco descuidada, acho que é muito importante a saúde bucal (E21, mãe de adolescente).

R30: Limpo a boca, escovo... agora no médico não vou muito não, acho frescura ter dor toda hora! Tudo da mente das pessoas, gente assim é que não tem nada pra fazer (E30, mãe de adolescente).

R26: O G (filho) é mais difícil, não ouve o que a mãe fala. Falo que tem que ir ao médico, né. Não posso mais levar, tem 18, né! O G (filho) tem adenoide, mas tinha que ter operado pequeno, o "estado" não conseguiu, agora já tá grande, tem que ser uma opção dele, não posso carregar ele, levar no médico (E26, mãe de adolescente).

Os pais exercem grande influência sobre seus filhos na adoção de comportamentos relacionados à saúde, pois a família constitui o primeiro ambiente de aprendizagem das crianças e dos adolescentes [26]. A família agrega um conjunto de valores, crenças, conhecimentos e hábitos que vêm influenciar práticas que promovam a saúde de seus componentes, ou, ao contrário, aumentem a vulnerabilidade dos mesmos para as doenças [27].

Além disto, há evidências de que as condições em que uma pessoa vive, seus primeiros anos de vida, bem como certos atributos dos pais e do grupo social a que ela pertence - renda e escolaridade dos pais, condições da moradia, nível de consumo - são fortes indutores do seu perfil de morbidade [28]. 
Sabe-se que modificar condutas sobre práticas de saúde no contexto familiar é, sem dúvida, um trabalho desafiador, sobretudo quando o cuidador influencia a postura de que quem está sob seus cuidados. Existem evidências na literatura da correlação negativa entre o adequado funcionamento familiar com a presença de problemas de comportamento na adolescência, ou seja, a família que funciona adequadamente é mais afetiva, desenvolve uma comunicação positiva, tem maior coesão familiar, além do envolvimento com os filhos. Com isso, enfrenta menos dificuldades de conduta inadequada do adolescente [29].

Portanto, a família mostra-se como um elemento de grande importância no estudo do adolescente, seja na educação, saúde ou psicodinâmica [30]. Apesar de complexo e muitas vezes conturbado, o período de transição para a adolescência pode sofrer influência dos eventos que ocorrem na vida familiar ou mesmo individual como, por exemplo, excesso de conflitos, baixa aceitação do filho, baixa afetividade e muito controle dos pais [31]. Tais eventos podem levar a problemas de comportamento dos adolescentes.

Outra característica da adolescência é o maior envolvimento com comportamentos de riscos, principalmente, porque os jovens tendem a estar mais próximos dos seus amigos e mais afastados do contexto familiar.

Estudos revelam que o apoio dos amigos foi evidenciado como um fator que pode influenciar na adesão aos comportamentos de risco já que o adolescente pode ser encorajado a envolver-se em alguma situação considerando a pressão dos pares [32].

Então, seria interessante conhecer de forma mais ampla as características dos grupos de amigos que os jovens se relacionam, chamando-os a participar das ações educativas propostas. Esta ideia apoia-se no caderno da Saúde na Escola desenvolvido pelo Ministério da Saúde [33], que enfatiza as atividades em grupo como estratégias da atenção básica para trabalho educativo com adolescentes.

Por conseguinte, o apoio da família e dos professores parece influenciar na direção contrária ao dos amigos quanto ao comportamento de risco, demonstrando que o apoio nesses contextos pode contribuir para o sentimento de pertencimento e ligação afetiva [34].

Este estudo entrevistou famílias em situação de vulnerabilidade social e, por isso, há de se considerar também que mudanças de comportamentos podem estar fora do alcance dos indivíduos.

É fato que piores condições de saúde tendem a ser encontradas em populações menos favorecidas. Sheiham (2014) [35] cita que a condição social e econômica pode ser considerada como um facilitador ou limitador da adesão do adolescente a hábitos relacionados com a saúde.

Os fatores de risco dessas famílias estão diretamente relacionados à exclusão, à desigualdade social, e não necessariamente aos aspectos individuais do adolescente. As condições indignas de pobreza, exclusão e vulnerabilidade social afetam a maioria das famílias pobres brasileiras de forma adversa ao desenvolvimento de crianças, adolescentes e adultos.

Porém, algumas famílias desenvolvem processos e mecanismos que garantem sua sobrevivência e cumprem seu papel de proteção e cuidado com competência, tornando o contexto essencial para o desenvolvimento saudável dos seus membros [36].

É necessário, então, que a família do adolescente possa ser envolvida nas ações desenvolvidas pelo profissional de saúde favorecendo escolhas saudáveis.

A Estratégia Saúde da Família representa papel fundamental na promoção da saúde quando o trabalho acontece sob a perspectiva dos determinantes sociais da saúde. É importante que a equipe promova o empoderamento de indivíduos e famílias, por meio da equidade, de ações intersetoriais [37]. Neste contexto, podem ser aplicadas atividades educativas voltadas para a população de adolescentes como um todo e, principalmente, para aqueles resistentes ao tratamento odontológico e que se encontram em situação de exclusão social, praticando desta forma o preceito da equidade nas ações de saúde. A elaboração das atividades educativas deve ser realizada em conjunto no nível da equipe de saúde, de forma multiprofissional e intersetorial.

Além disso, considerando que as parcerias entre educadores e profissionais de saúde, trabalhando na educação e promoção de saúde dos adolescentes, estabelecem resultados favoráveis em relação à sua saúde bucal [38], pode-se sugerir, por exemplo, que a equipe firme parceria com os setores da educação e da cultura, a fim de desenvolver atividades culturais como cinema, teatros, oficinas. Estas atividades devem envolver temas relevantes sobre a saúde bucal, inclusive os malefícios da não adesão ao tratamento odontológico, despertando o interesse e a curiosidade dos jovens e da família sobre o assunto. 
0 uso de temas do cotidiano que despertem a curiosidade e o envolvimento emocional dos adolescentes nas atividades educativas parece ser uma alternativa favorável para o desenvolvimento de pensamento crítico. Para Schall e Strunchner (1999) [39], a arte desencadeia emoção e esta contribui para a construção de sentidos, preenchendo a lacuna entre conhecimento e a esperada mudança de comportamento.

Silveira Filho et al. (2005) [40], por meio da metodologia problematizadora, trabalharam com o conceito de exercício da curiosidade de Paulo Freire e neste contexto, o tema "beijo", que desperta muito interesse para os adolescentes, foi escolhido como mobilizador de discussão de saúde bucal. Os resultados foram efetivos na construção de relação de confiança entre profissionais e adolescentes, facilitando o desenvolvimento do processo educativo. Para os profissionais, esta metodologia significou a ruptura com padrões educativos historicamente construídos na odontologia, gerando sentimentos de satisfação e de busca por novas metodologias de abordagens educacionais.

Engajar os adolescentes ativamente no processo educativo parece ser um desafio, sendo as estratégias em grupo uma importante contribuição. Nos grupos é possível verificar senso de coesão, de comunicação, interação, de coletividade e de planejamento, de metas comuns e onde cada participante possa se conhecer e ajustar suas relações sociais [41]. Ao mesmo tempo, é possível que o contato individual aja como fator restritivo em muitos casos, sendo que nas estratégias em grupos geralmente os adolescentes sentem-se mais desinibidos e entusiasmados [42].

Desta forma, o empoderamento do participante fica favorecido, pois o indivíduo constrói e reconstroem seus saberes, suas ideias, significados e representações e assim, direciona suas ações e as tomadas decisões sobre o que, como e porque agir de determinada maneira e não de outra [43].

Então, como exemplo prático, sugere-se a formação de grupos operativos na unidade de saúde que podem ser realizados na própria USF ou nos espaços sociais do bairro, como escolas e centros comunitários. Nesses grupos podem ser trabalhadas minimamente a causalidade dos agravos, a importância do tratamento odontológico, formas de prevenção, a revelação de placa e a escovação supervisionada, por meio da problematização das questões de saúde bucal, integração e a democratização do conhecimento a partir do compartilhamento das vivências de cada participante. Isso é revelado pela literatura, considerando o cenário encontrado no presente estudo, sugere-se incluir a discussão entre a relação de desfecho da higiene e limpeza com diferentes situações de saúde.

As equipes devem também incluir as atividades educativas na rotina do trabalho dos agentes comunitários de saúde e da Equipe Saúde da Família, a partir de critérios de risco ou da identificação do núcleo familiar como um fator determinante no processo saúde doença.

Mas, no cenário atual, a maneira de conceber o conceito de promoção de saúde é bastante diferente da que é praticada nos serviços de saúde. A promoção da saúde vivenciada pelas equipes de saúde dá ênfase à culpabilização dos indivíduos, àquilo que as pessoas fazem "de errado" ou aquilo que não estaria de acordo com algum "conhecimento científico" [44]. Este modo de "cuidar" dos profissionais da saúde é, frequentemente, reproduzido no contexto familiar.

A equipe de saúde precisa ser capacitada a "olhar" a família como sujeitos, substituindo a tradicional relação distanciada com o indivíduo, por níveis mais profundos de acolhimento e vínculo com as mesmas.

Esse "novo olhar" da equipe para a família poderia ser discutido nos espaços coletivos de conversas com a participação de uma equipe interdisciplinar, baseado nos pressupostos da Educação Permanente em Saúde. 0 enfoque das discussões se daria na busca da ressignificação da relação entre a família e a equipe na perspectiva da horizontalidade, dando ênfase ao dispositivo do acolhimento. Desta forma, buscar-se-ia, na abordagem de comunicação com os membros da família, uma forma mais humanizada de relacionamento por meio de falas, perguntas, posturas e gestos capazes de gerar empatia e vínculo, minimizando as relações de poder instituídas na relação entre profissionais de saúde e pacientes.

É importante dizer que essa postura acolhedora do profissional aconteceria em todas as atividades e rotinas da equipe de saúde, a saber: na visita domiciliar, no atendimento individual, na atividade em grupo, entre outros.

Sabe-se que a qualidade da comunicação aumenta a adesão ao tratamento, melhora o prognóstico, aumenta a satisfação e diminui conflitos com os profissionais de saúde [45].

Mesmo com o passar dos anos, os programas educativos ainda são considerados as estratégias mais utilizadas para melhorar a adesão [46]. Estes programas procuram envolver no tratamento, tanto os jovens, quanto seus familiares [47]. Esse envolvimento pode se dar desde a participação dos pais nas atividades culturais, nos grupos das unidades, até mesmo no acompanhamento nas consultas 
odontológicas e no tratamento das necessidades bucais da família. Por isso, a importância da qualidade da relação comunicativa entre os jovens e seus pais. Estudos recentes têm procurado demonstrar a importância de trazer a família para as reuniões das equipes de saúde com objetivo de transformar a informação em comunicação e incrementar a adesão [48].

\section{2ํ-- Eixo: regras saudáveis na perspectiva do cuidador em relação ao indivíduo que recebe o cuidado}

Este eixo está relacionado aos indivíduos que recebem o cuidado quanto à alimentação, limpeza dos dentes e do corpo, qualidade do sono e prática de atividade física. Esse eixo foca na fala do entrevistado, aspectos que evidenciam o cumprimento ou não de práticas saudáveis pelos adolescentes.

Embora haja fiscalização do cuidador no cumprimento das regras, por parte das pessoas cuidadas, percebe-se no extrato das falas a seguir, que o indivíduo não cumpriu as regras saudáveis.

R22: Eles crescem e é complicado. Os pequenos ainda consigo levar na rédia, mas eles.... Fico em cima para almoçar bem, jantar bem, escovar o dente, dormir cedo. Se não cuido você sabe, só quer comer porcaria, não quer escovar os dentes quando acorda, quando vai dormir (E22, mãe de adolescente).

Nota-se também o esforço do cuidador no cumprimento de regras saudáveis ligadas à alimentação e limpeza dos dentes, apesar do desinteresse do indivíduo em cumpri-la.

R31: Ahhh...eu sempre faço de tudo. Tomo cuidado em comprar verduras e frutas. Lavo direitinho... às vezes perde tudo (risos). Eles não ligam, mas minha parte eu faço. Quando era pequenos eu pedia pra escovar, ficava em cima. Agora não, estão grandes, já sabem o que fazem (E31, mãe de adolescente).

Pela perspectiva do "não cumprimento de regras saudáveis" verifica-se que o adolescente apresenta certa autonomia do seu cuidado em saúde, não atribuindo sentido de importância ou prioridade na prática de ações que melhorem sua qualidade de vida.

Na literatura, a autonomia é definida como a habilidade para pensar, sentir, tomar decisões e agir por conta própria [49]. Para o adolescente, o desafio desse processo envolve o desejo de ser autônomo e independente, ao mesmo tempo, e preservar a ligação com a família e a sociedade. Pensa-se que o ideal seria a dependência mútua, ou seja, a possibilidade de o jovem conseguir agir por conta própria, ter comportamentos independentes, porém sem afastar-se de sua família, que deve aceitar este movimento, permitindo o ir e vir do jovem [50].

Diante deste cenário, é necessário introduzir mudanças na vida familiar, o que supõe acordos entre os pais e os filhos. Estas mudanças estão relacionadas à autoridade, disciplina, estilo de vida, estilo de educação e de comunicação. Isto se tornará possível se os pais aprenderem a escutar seus filhos, mediante uma escuta seletiva, se souberem respeitar seus limites e a individualidade [51]. Desta forma, os pais estarão fomentando a autonomia dos seus filhos.

No entanto, tal contexto acende uma reflexão: Como motivar o adolescente a desenvolver habilidades vitais que auxilie nas escolhas de práticas mais saudáveis?

A OMS considera que o desenvolvimento de habilidades pessoais está relacionado ao empoderamento, caracterizado pela habilidade individual e psicológica de tomar decisões e ter maior controle sobre a vida pessoal [52].

No Glossário Temático da Promoção da Saúde o empoderamento é definido como o "processo em que indivíduos ou grupos desenvolvem habilidades e capacidades para a tomada de decisão e controle sobre suas vidas e sobre os determinantes sociais" [53]. A literatura revela que o empoderamento traz mudanças sociais, políticas e nos ambientes físicos que interferem na saúde das pessoas [54].

Anderson (1986) descreve a necessidade do desenvolvimento de "habilidades para a saúde". Pode-se citar o uso de técnicas assertivas para resistir ao consumo de drogas, por exemplo, de exigir o cuidado médicoodontológico de qualidade, como também, tomadas de decisões em diversas situações [55]. Nessas situações pode-se destacar o desenvolvimento de habilidades que auxiliem na escolha do adolescente em aderir ao tratamento odontológico.

Contudo, a equipe de saúde deve compreender, que às vezes, a opção não saudável é a única escolha que o indivíduo possui. 0 profissional precisa ter cuidado para não "culpabilizar" o indivíduo por não aderir às recomendações sugeridas por ele [55].

O fato de serem formados segundo o modelo biomédico, muitos profissionais desconsideram as condições 
de vida, percepções, valores, representações simbólicas, relações de poder, crenças e sentimentos dos indivíduos [56].

Por outro lado, o sucesso do profissional na Atenção Básica em Saúde ocorre quando o sujeito que procurou sua atenção e cuidados adquire autonomia e emancipação, tornando-se independente do serviço de saúde [57]. Todavia, trata-se de um grande desafio para o profissional de saúde, uma vez que ele também precisa desenvolver habilidades capazes de conduzir e empoderar o sujeito que recebe os cuidados ao reconhecimento de sua competência.

E, por fim, a introdução do conceito de vulnerabilidade na saúde bucal, numa abordagem combinada, é de primordial importância, pois permite que análises estatísticas mais adequadas, contudo mais complexas, demonstrem o risco e suas associações, bem como desvendem os significados das doenças para os sujeitos através da pesquisa qualitativa, apresentando, assim, a compreensão do processo saúde-doença nessa população, nas suas várias e complexas traduções. Esse nível de compreensão, a ser desvendado no presente estudo pela pesquisa qualitativa - que inclui o subjetivo e o social - é particularmente importante quando se considera, como exposto por Botazzo (2006) [45] que "se o corpo é socialmente formado, igualmente se pode falar em formação social da boca".

Como consequência, essa pesquisa fornece conhecimentos e informações, essenciais para o desenvolvimento de políticas públicas que garantam a integralidade na atenção em todos os níveis, especialmente na atenção básica, contribuindo para a melhoria da qualidade de vida desta população.

\section{CONSIDERAÇÕES FINAIS}

A análise dos sentidos atribuídos revelou que a perspectiva de "cuidado em saúde" dos entrevistados, descarta fatores macrossociais e considera a limpeza como sinônimo deste tipo de cuidado, bem como desconsidera outros comportamentos de risco relacionados às doenças, inclusive bucais, que acometem os adolescentes.

A importância de conhecer os cuidados da família para com o adolescente, especificamente em relação à prática odontológica, revela que esses aspectos podem estar interagindo e influenciando os filhos nas decisões com relação à prevenção e adesão ao tratamento de doenças bucais.

Tendo em vista os resultados obtidos, recomenda-se o empenho da equipe em parcerias com outros setores da sociedade na construção de ambientes saudáveis com potencial para a adoção de ações e atividades educativas que facilite a aquisição de hábitos saudáveis e a manutenção dos mesmos.

\section{AGRADECIMENTO}

Os autores gostariam de agradecer o apoio financeiro da FAPESP (bolsas \# 2013/ /17340-9).

Aos diretores das escolas, professores e todos os adolescentes que contribuíram para a realização da pesquisa.

\section{REFERÊNCIAS}

[1] Allen JP, Land D. Attachment in adolescence. In: Cassidy J, Shaver PR, editors. Handbook of attachment theory and research. Guilford. New York, 19990.

[2] Costa M, Mota, CP. Configuração familiar, género e coping em adolescentes: papel dos pares. Psicol. estud. 2012; 17(4): 567-575.

[3] Miotto MMB; Barcellos LA. Contribuição das Ciências Sociais nas práticas de Saúde Pública. Revista Brasileira de Pesquisa em Saúde. 2009; 11(2): 43-48.

[4] Teodoro MLT, Cardoso, BM, Freitas, A C H. Afetividade e conflito familiar e sua relação com a depressão em crianças e adolescentes. Psicologia: Reflexão e Crítica. 2010; 23(2): 324-333.

[5] Poletto M, Koller SH. Contextos ecológicos: promotores de resiliência, fatores de risco e de proteção. Estudos de Psicologia. 2008; 25 (3): 405-416.

[6] Schenker M, Minayo MCS. A importância da família no tratamento do uso abusivo de drogas: uma revisão da literatura. Cad Saúde Pública. 2004; 20(3):649-659. 
[7] World Health Organization. World Health Organization Adherence to long term therapies. Evidence for action. Switzerland, 2003.

[8] Haynes RB. Determinants of compliance: The disease and the mechanics of treatment. Baltimore MD, Johns Hopkins University Press, 1979.

[9] Pierin AMG, Strelec MAAM, Mion Jr. D. O desafio do controle da hipertensão arterial e a adesão ao tratamento. In: Pierin AMG. Hipertensão arterial: uma proposta para o cuidar. São Paulo: Ed. Manole; 2004: 275-289.

[10] Friberg, F, Scherman, M.H. Can a teaching and learning perspective deepen understanding of the concept of compliance? A theoretical discussion. Scandinavian. Journal of Caring Sciences. 2005; 19: 274279.

[11] Organização Mundial da Saúde. Levantamentos básicos em saúde bucal. Tradução de Ana Júlia Perrotti Garcia. 4.ed. São Paulo: Santos, 1999: 66.

[12] Vazquez FL, Cortellazzi KL, Gonçalo CS, Bulgareli JV, Guerra LM, Tagliaferro ES, Mialhe FL, Pereira AC. Qualitative study on adolescents' reasons to non-adherence to dental treatment. Cien Saude Colet. 2015 Jul;20(7):2147-56.

[13] Pope C, Mays N. Qualitative Research in Health Care. Blackwell Publishing, 2006.

[14] Triviños ANS. Introdução à pesquisa em ciências sociais: a pesquisa qualitativa em educação. São Paulo: Atlas; 1998.

[15] Fontanella BJB, Magdaleno Júnior R. Saturação teórica em pesquisas qualitativas: contribuições psicanalíticas. Psicol Estud 2012; 17(1): 63-71.

[16] Gomes R. Análise e interpretação de dados de pesquisa qualitativa. In: Minayo MCS, organizadores. Pesquisa Social. Teoria, método e criatividade. Petrópolis: Vozes; 2010.

[17] Pelicioni MCF, Mialhe FL. Educação e promoção da saúde: teoria e prática. São Paulo: Santos; 2012.

[18] World Health Organization. Ottawa Charter for Health Promotion. First International Conference on Health Promotion, Ottawa, 21 November 1986]. Disponível em: http://www.who.int/healthpromotion/conferences/previous/ottawa/en/.(acesso em 10 de setembro 2015).

[19] Leavell S, Clark EG. Medicina preventiva. São Paulo: McGraw-Hill; 1976.

[20] Buss PM. Uma introdução ao conceito de promoção da saúde. In: Czeresnia D, Freitas CM, organizadores. Promoção da saúde: conceitos, reflexões, tendências. 2. ed. Rio de Janeiro: FIOCRUZ; 2009.

[21] Lalonde, M. A new perspective on the health of Canadians: a working document. Minister of supply and services, 1981.

[22] Mendonça TC. Mutilação dentária: concepções de trabalhadores sobre a responsabilidade pela perda dentária. Cadernos de Saúde Pública. 2001; 17(6): 1545-47.

[23] Domingues SM, Carvalho ACD, Narvai PC. Saúde bucal e cuidado odontológico: representa- ções sociais de mães usuárias de um serviço público de saúde. Rev Bras Crescimento Desenvol Hum. 2008; 18(1): 66-78.

[24] Bandura A, Azzi, RG, Polydoro, S. Teoria Social Cognitiva: conceitos básicos. Porto Alegre: ArtMed. 2008: 176.

[25] Pereira JC, Neto CA, Gonçalves SA. Dentística: uma abordagem multidisciplinar. São Paulo, Artes médicas; 2014.

[26] Raphaelli COC, Azevedo MR, Hallal PC. Associação entre comportamentos de risco à saúde de pais e adolescentes em escolares de zona rural de um município do Sul do Brasil. Cad.Saúde Pública. 2011; 27(12): 2429-2440.

[27] Instituto Brasileiro de Geografia e Estatística. Pesquisa Nacional de Saúde do Escolar. Rio de Janeiro; 2009.

[28] Peres MA, Peres KGA. A saúde bucal no ciclo vital: Acúmulo de riscos ao longo da vida. In: José Leopoldo Ferreira Antunes e Marco Aurélio Peres. (Org.). Fundamentos de Odontologia: epidemiologia da 
saúde bucal. 1 ed. Rio de Janeiro: Guanabara Koogan; 2006; 1: 249-259.

[29] Levin, K. A., Kirby, J., \& Currie, C. Adolescent risk behaviours and mealtime routines: does family meal frequency alter the association between family structure and risk behaviour? Health Education Research. 2012; 27(1): 2-35.

[30] Aberastury A, Knobel M. Adolescência normal. Buenos Aires, Paidós, 1971.

[31] Dessen, MA, Polonia, AC. A família e a escola como contextos de desenvolvimento humano. Paidéia. 2007; 7(36): 21-32.

[32] Albert D, Steinberg L. Judgment and decision making in adolescence. Journal of Research on Adolescence. 2011; 21(1), 211-224.

[33] Brasil. Ministério da Saúde. Cadernos de Atenção Básica; n. 24. Saúde na escola Brasília, 2009: 96.

[34] Fosco GM, Stormshak EA, Dishion TJ, Winter CE. Family relationships and parental monitoring during middle school as predictors of early adolescent problem behavior. J Clin Child Adolesc Psychol. 2012;41(2):202-13.

[35] Sheiham A, Moysés SJ, Watt RG, Bönecker M. Promoting the Oral Health of Children. 2014, p 288309.

[36] Yunes MAM, Szymansky H. Resiliência: noção, conceitos afins e considerações críticas. In: TAVARES, J. (Ed.). Resiliência e educação. São Paulo: Cortez, 2001: 13-42.

[37] Pellegrini Filho A, Buss PM, Esperidião MA. Promoção da saúde e seus fundamentos: determinantes sociais de saúde, ação intersetorial e políticas públicas saudáveis. In: Paim JS, AlmeidaFilho NA. Saúde coletiva: teoria e prática. Rio de Janeiro: Medbook; 2014.

[38] Haleem A, Siddiqui MI, Khan AA. School-based strategies for oral health education of adolescents-a cluster randomized controlled trial. BMC Oral Health. 2012 Dec 18;12:54.

[39] Schall VT, Struchiner M. Health education: new perspectives. Cad Saude Publica. 1999 Nov;15 Suppl 2:4-5.

[40] Silveira Filho AD, Medeiros IY, Justo CMP, Junqueira SR, Pereira OMTB, Pelicioni MCF. O beijo como mobilizador para educação em saúde: ênfase na saúde bucal de adolescentes: relato de uma experiência. Rev. Bras Desenv Hum. 2005; 15(3): 57-68

[41] Trentini M, Gonçalves HT. Pequenos grupos de convergência: um método no desenvolvimento de tecnologias na enfermagem. Texto Contexto Enferm. 2000; 9 (1): 63-78.

[42] Hoga LAK, Abe CT. Relato de experiência sobre o processo educativo para promoção de saúde de adolescentes. Rev. Esc Enf USP 2000; 34(4): 407-412.

[43] Ferreira MA. A educação em saúde na adolescência: grupos de discussão como estratégia de pesquisa e cuidado-educação. Texto-Contexto Enferm. 2006; 15(2): 205-211.

[44] Botazzo C. A bucalidade no contexto da Estratégia Saúde da Família: ajudando a promover saúde para indivíduos, grupos e famílias in Moysés ST; Kriger L; Moysés SJ. Saúde Bucal das FamíliasTrabalhando com Evidências. São Paulo: Artes Médicas, 2008; 5: 65-70.

[45] Botazzo C. Sobre a bucalidade: notas para a pesquisa e contribuição ao debate. Cienc. Saúde Coletiva. 2006; 11(1): 7-17.

[46] Oliveira VZ, Gomes WB. Comunicação médico-paciente e adesão ao tratamento em adolescentes portadores de doenças orgânicas crônicas. Estudos de Psicologia. 2004; 9(3): 459-469.

[47] Nolan T, Desmond K, Herlich R, Hardy S. Knowledge of cystic fibrosis in patients and their parents. Pediatrics. 1986; 77: 229-235.

[48] Williams J, DeMaso DR. Pediatric team meetings: the mental health consultant's role. Clinical Child Psychology and Psychiatry. 2000; 5(1): 105-113.

[49] Fleming M. Adolescent autonomy: desire, achievement and disobeying pares between early and late adolescence. Australian Journal of Education and Developmental Psychology, Australia. 2005; (5): 116.

[50] Reichert CB, Wagner AI. Considerações sobre a autonomia na contemporaneidade. Estudos e 
pesquisas em psicologia, UERJ. 2007; 7 (3): 405-418.

[51] Rios Gonzáles JA. Los ciclos vitales de la família y la pareja?crisis u oportunidades?. Madrid: Editorial CCS, 2005.

[52] World Health Organization. Health education and promotion unit. The Health-promoting workplace: making it happen. Geneva: WHO; 1998.

[53] Brasil. Ministério da Saúde. Secretaria-Executiva. Secretaria de Vigilância em Saúde. Glossário temático: promoção da saúde. Brasília: Ministério da Saúde; 2012.

[54] Laverack G. Health promotion practice: power and empowerment. London: Sage; 2004.

[55] Mialhe FL. Educação e promoção da saúde e saúde bucal. Nova Odessa: Napoleão; 2016.

[56] Mialhe FL, Guerra LM. Avaliação das práticas de educação em saúde entre acadêmicos de odontologia e profissionais de serviços públicos. In: Pinto T, Groisman S, Moysés SJ, organizadores. PROODONTO prevenção: programa de atualização em odontologia preventiva e saúde coletiva: ciclo 8. Porto Alegre: Artmed/Panamericana; 2015: 55-126.

[57] Gazzinelli MF, Penna C. Educação em saúde: conhecimentos, representações sociais e experiências da doença. In: Gazzinelli MF, Reis DC, Marques RC, organizadores. Educação em saúde: teoria, método e imaginação. Belo Horizonte: UFMG; 2006: 25-33. 


\section{Capítulo 3}

Papel de enfermería en el sistema de cuidados familiares cuidadora extranjera-persona mayor dependiente

María José Morales-Gázquez.

Epifanía Natalia Medina-Artiles

María Milagros Torres-Garcia

María del Carmen Navarro Rodrígues

Carmen Trigueros-Cervantes

Resumen: Objetivo: caracterizar el papel de la enfermera en la situación de cuidados a personas mayores dependientes ofrecidos por cuidadoras inmigrantes. Metodología: estudio fenomenológico de corte interpretativo, basado en entrevista grupal y grupo focal con enfermeras, cuyo análisis de datos se basó en la teoría fundamentada apoyado en el CQDAS Nudist NVivo 10.0. Informe resultados: las enfermeras participantes han mostrado conocimiento acerca de los cuidados desarrollados por estas mujeres, así como de sus condiciones laborales y su realidad. Además, asumen la responsabilidad de la cuidadora. Conclusiones: El papel de la enfermera en este fenómeno de cuidados es necesario y beneficioso. La enfermera pretende delegar en la cuidadora parte de los cuidados de la persona mayor dependiente y para ello la forma, instruye y trabaja con ella. El modo de llevarlo a cabo está relacionado con tareas como la comunicación, la valoración, observación, anamnesis, consejo, adiestramiento, supervisión o formación, entre otras.

Palabras clave: Ancianos; Cuidadores Inmigrantes; Cuidados Familiares; Enfermería Transcultural; Cuidados de Enfermería en el Hogar. 


\section{INTRODUCCIÓN}

El sistema sanitario español goza de gran prestigio tanto a nivel nacional como internacional. Con él los profesionales de enfermería están igualmente bien valorados.

En el ámbito domiciliario uno de los grandes retos de la enfermería actual es la atención a la persona mayor dependiente (PMD) y su entorno de cuidados. Fenómeno complejo en sí mismo que, cuando forma parte del mismo una cuidadora remunerada extranjera, su complejidad aumenta, pues las realidades que lo forman son muy diferentes entre sí. En estas circunstancias, proporcionar unos cuidados adecuados requiere de una atención enfermera de calidad que consiga como fin último el bienestar de la PMD así como el trabajo adecuado y seguro para ambos (Ballester, 2008; Benavente, 2007; Cachón, 1995; Durán, 2004; Martínez, R., 2006; 2007; Martín \& Cano, 2008).

Por ello, el objetivo de este trabajo es caracterizar el papel de la enfermera en la situación de cuidados a PMD ofrecidos por cuidadoras inmigrantes.

\section{METODOLOGÍA}

Para responder a la cuestión planteada se ha realizado un estudio fenomenológico de corte interpretativo, basado en una entrevista grupal y un grupo focal con enfermeras, cuyo análisis de datos se basó en la teoría fundamentada apoyado en el CQDAS Nudist NVivo 10.0.

\subsection{EL GRUPO FOCAL}

Se trata de un tipo de entrevista grupal donde la interacción entre los participantes produce datos que serían menos accesibles sin esa interacción grupal. Uno de los objetivos de los grupos focales consiste en el enriquecimiento y la exploración de la interpretación de los resultados de la investigación (Bertoldi, Fiorito, \& Álvarez, 2006; Morse, 2005).

En consideración a los objetivos y preguntas de nuestra investigación, el guion temático de partida, fue el siguiente:

Temática general:

- $\quad$ Papel de la enfermería en el sistema de cuidados creado entre cuidadora familiar extranjera y PMD en domicilio

Temáticas específicas:

- $\quad$ Experiencias vividas con cuidadoras extranjeras en el desarrollo de su profesión

- $\quad$ Procedencias más frecuentes de las cuidadoras

- Formas en que enfermería trabaja con las cuidadoras

- La enfermería en la formación de las cuidadoras extranjeras

La selección de los participantes se llevó a cabo teniendo en cuenta criterios de representatividad en función de:

- Enfermeros de cualquier ámbito asistencial pero que hubieran tenido experiencia con estas cuidadoras en algún momento de su desarrollo profesional o a nivel personal

- $\quad$ Enfermeros que hubieran desarrollado su labor con personas mayores de las islas de Lanzarote o Fuerteventura

\subsection{ANÁLISIS DE LOS ASPECTOS FORMALES DEL GRUPO FOCAL}

El grupo focal se desarrolló en un espacio amplio con iluminación natural suficiente, así como correcta disposición de los participantes y la colocación de una videocámara que permitió la grabación del procedimiento, también se utilizó una grabadora de audio para garantizar el registro correcto de la conversación.

La fase de implementación se desarrolló con la generación de un ambiente de confianza y respeto. Se dieron a conocer los objetivos del estudio, así como el propósito y valor del grupo focal dentro del mismo. 
También se les comunicó el uso previsto de los datos y los criterios de selección de los participantes. Además, todos firmaron un consentimiento informado donde se explicaba todo ello, así como el procedimiento de obtención y tratamiento de los datos y la garantía de la confidencialidad.

Durante el desarrollo del mismo tuvo lugar la participación de todos los miembros del grupo, con las condiciones de respeto comentadas al principio, y se generaron algunas conversaciones.

En la entrevista grupal de enfermeras los criterios de inclusión fueron los mismos que para el grupo focal.

Los atributos de los participantes en ambas técnicas se presentan en la Tabla 1.

Tabla 1. Características participantes en Grupo Focal y en Entrevista Grupal

\begin{tabular}{|c|c|c|c|c|}
\hline & participante & sexo & $\begin{array}{c}\text { edad } \\
\text { (en años) }\end{array}$ & $\begin{array}{c}\text { experiencia } \\
\text { laboral }\end{array}$ \\
\hline \multirow{8}{*}{$\begin{array}{l}\text { atributos } \\
\text { participantes } \\
\text { en el grupo } \\
\text { focal }\end{array}$} & GFE1 & hombre & $45-50$ & 8 \\
\hline & GFE2 & mujer & $45-50$ & 25 \\
\hline & GFE3 & mujer & $60-65$ & 10 \\
\hline & GFE4 & mujer & $\begin{array}{c}65-70 \\
\text { (jubilada) }\end{array}$ & 20 \\
\hline & GFE5 & mujer & $45-50$ & 3 \\
\hline & GFE6 & mujer & $35-40$ & 11 \\
\hline & GFE7 & mujer & $30-35$ & 4 \\
\hline & GFE7 & mujer & $45-50$ & 27 \\
\hline \multirow{4}{*}{$\begin{array}{c}\text { atributos } \\
\text { participantes } \\
\text { en entrevista } \\
\text { grupal }\end{array}$} & EG1 & mujer & $40-45$ & 15 \\
\hline & EG2 & mujer & $40-45$ & 10 \\
\hline & EG3 & mujer & $45-50$ & 22 \\
\hline & EG4 & hombre & $35-40$ & 8 \\
\hline
\end{tabular}

\subsection{PROCESO DE CONSTRUCCIÓN DEL ÁRBOL DE CATEGORÍAS PARA EL ANÁliSiS DE LA INFORMACIÓN OBTENIDA}

El punto de partida del análisis consistió en una primera categorización y la creación de los primeros nodos libres, obtenidos a partir de las temáticas propuestas en el desarrollo del grupo (Figura 1). A partir del análisis de estas grandes categorías, se crearon las subcategorías o ramificaciones de dicho árbol.

Fig. 1. Grandes temas grupo focal

\begin{tabular}{|c|}
\hline Nodos \\
\hline 1 Nombre \\
\hline 00. Caracteristicas de un buen cuidado \\
\hline 01. Caracteristicas de un mal cuidado \\
\hline 02. Procedencia cuidadoras contratadas \\
\hline 04. Maltrato empleadores \\
\hline 05. Temas emergentes en el trabajo de cuidar \\
\hline$\oplus$ 06. Temas emergentes enfermeros \\
\hline 由 07. Enfermería y cuidadoras \\
\hline
\end{tabular}

A continuación, exponemos cómo se ha realizado la producción lineal del discurso, así como las temáticas abordadas por cada uno de los participantes. Como se puede observar en la Figura 2, durante el desarrollo de esta técnica, los participantes han mantenido una conversación muy viva. Ello ha contribuido a la facilidad del desarrollo de la técnica y a la calidad de los datos surgidos en la misma. En dicha figura pretendemos ilustrar cómo se ha producido la linealidad de los discursos, así como la cantidad de temas 
que surgieron. Como se aprecia, la moderadora, además de introducir el primer tema, sobre la presentación y experiencia de cada uno de los participantes, no tuvo necesidad de introducir ningún tema más hasta los dos finales, representados con el número 12 y 13 respectivamente en la figura.

Fig. 2. Producción temática y lineal del discurso del grupo focal de enfermeras

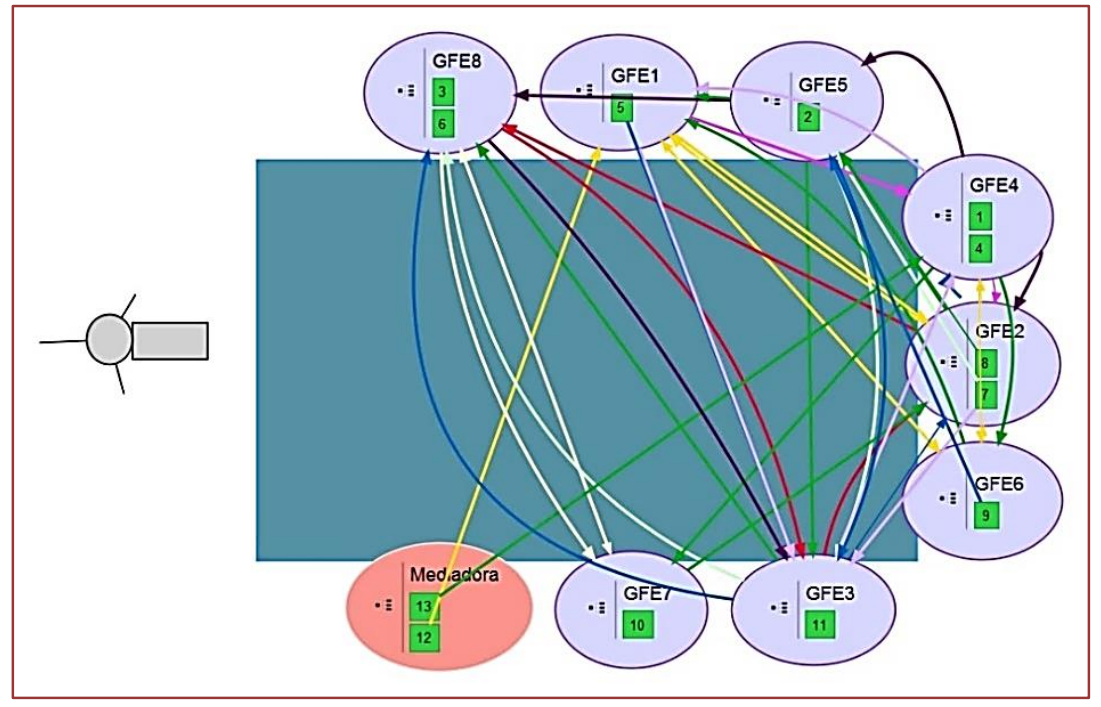

La intensidad de la participación de cada miembro del grupo se muestra en la figura 3.

Fig. 3. Densidad de codificación por participante grupo focal de enfermeras

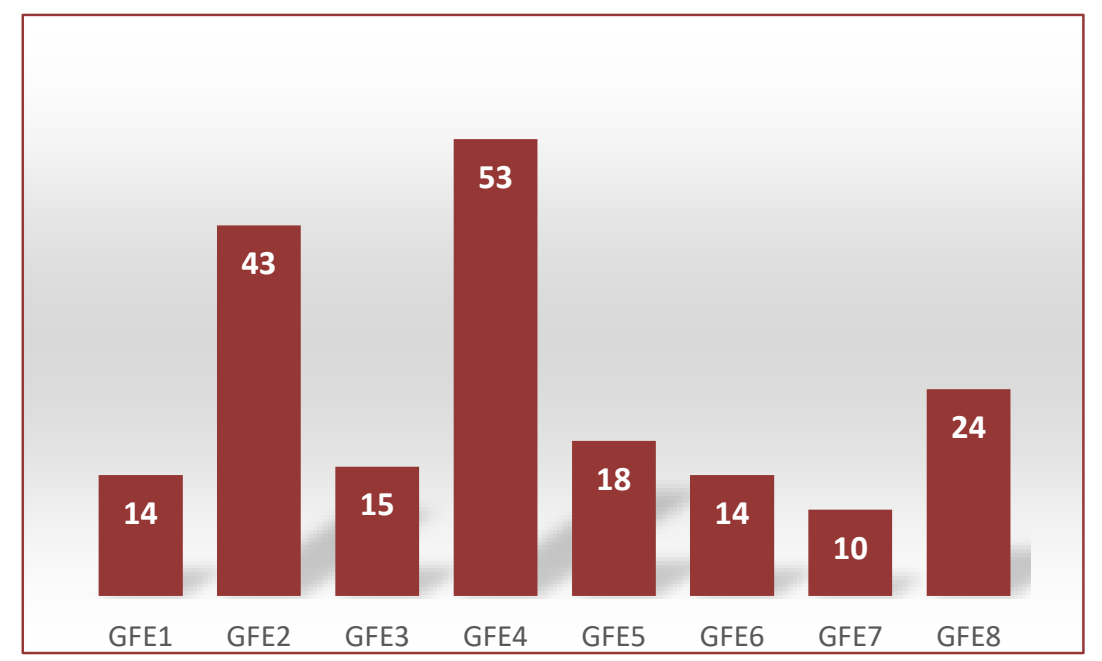

\section{FACTORES CULTURALES QUE INFLUYEN EN EL MODO DE ENTENDER Y REALIZAR EL CUIDADO}

Sobre los aspectos relacionados con su contacto directo con cuidadoras, las enfermeras han puesto de manifiesto que:

La enfermera asume su responsabilidad del cuidado a la persona mayor dependiente y a su entorno. De esta manera, la enfermera también asume la responsabilidad de la cuidadora del anciano. 
El objetivo final de enfermería es poder delegar parte de los cuidados del anciano dependiente en su cuidadora. Si las cuidadoras conocen su trabajo y «se dan cuenta de lo que tienen que hacer (...) la señora está bien limpiada, las úlceras bien y además (...) no fallaba en los cambios» (GFE1) entonces este enfermero relata que, con alguna de estas cuidadoras «no tuve que involucrarme en explicarle cada paso de cada cuidado» (GFE1).

En el caso de que la cuidadora sea inexperta o desconozca el trabajo de cuidados, se comienza, por la observación, como esta enfermera que, «cuando voy a un domicilio (...) tú ya lo ves, con una sola mirada...enseguida sabes... sí, porque cuando tú vas a un domicilio un poco lo valoras todo» (GFE6).

Trabajan conjuntamente con la cuidadora a fin de que el paciente se vea beneficiado, de manera que «siempre que ella no sabe, tienes que pegarte con ella un pedazo de trabajo» (GFE6) y «de formación (...) explicarles lo básico y luego, cuando ya haces el seguimiento, revisas y corriges...» (GFE2).

Por lo general, enfermería encuentra en las cuidadoras un aliado en su trabajo de atención al anciano dependiente, comprueba que «a veces ves tú que se preocupa más la cuidadora que la propia familia» (GFE6).

Aun así, es posible que la cuidadora no demuestre aprender de la enfermera y a veces, «te cansas de ir, de asesorar... y mira, cambios posturales, esto, aquello... y luego otra vez... y siempre lo mismo, ¿sabes? que hay veces...» (GFE6).

Además, enfermería realiza una labor de mediadora entre la cuidadora y la familia del RC, como esta enfermera al detectar un mal cuidado «se comentó con los hijos y los hijos también te comentan a ti, claro porque formas parte también del cuidado del abuelo» (GFE5).

Las enfermeras también coinciden en considerar muy importante el tipo de relaciones establecidas entre las cuidadoras y los ancianos y sus familiares, para que la situación de cuidados se consolide. Por ello, el periodo de adaptación es delicado y muy influenciado por la diferencia cultural, "porque hay que acostumbrarse a las comidas, porque eso es importantísimo, porque el potaje, el gofio, lo que se hace típico de aquí pues la otra no sabe hacerlo» (GFE2).

La cuidadora acaba sustituyendo verdaderamente al familiar, la enfermera trata con la cuidadora aspectos relacionados con la responsabilidad de la salud del RC, este enfermero explica que «nosotros en urgencias (...) muchas veces a la hora de hacer la valoración sacamos al familiar porque no se entera y llamamos al cuidador. Y muchas veces el cuidador, es eso, una persona inmigrante que vive las veinticuatro horas, maneja la situación, se conoce todos los hábitos alimenticios...» (EGE4), incluso, «mejor que los familiares» (EGE2).

Conseguir llegar a esta situación lleva tiempo y esfuerzo, por ello es muy importante «que haya una buena comunicación» (EGE6). Así, para las enfermeras «es muy importante, cuando tú ya conoces al cuidador, te da esa confianza de saber: cualquier cosa, me llama, te da tranquilidad» (GFE4).

Los discursos generados por las enfermeras han puesto de manifiesto la estrecha relación que enfermería establece con la cuidadora de ancianos en su domicilio.

Las enfermeras participantes han mostrado conocimiento no solo de acerca de los cuidados desarrollados por estas mujeres, sino también sobre sus condiciones laborales y su realidad.

Al formar parte del entorno de cuidados de la persona mayor dependiente la enfermera asume la responsabilidad de la cuidadora.

El objetivo final de enfermería es conseguir que la cuidadora realice unos cuidados adecuados, eficaces y seguros tanto para ella como para su receptor de cuidados. Para ello es necesario establecer una relación de confianza donde la comunicación entre ambas sea fluida, clara y eficaz.

La enfermera dedicará tiempo al establecimiento de esa relación de confianza, así como a la instrucción y formación de la cuidadora en todo lo que ésta precise para que consiga cuidar adecuadamente de la persona que tiene a su cargo.

Enfermería ha mostrado su papel de liderazgo en este fenómeno de cuidados desde la realización de diversas funciones. Por un lado, ha actuado como eje vertebrador de todas las partes que intervienen en el entorno de cuidados del anciano, actuando como mediador entre ellas. Por otro lado, enfermería dirige y contribuye a la organización y realización de los cuidados que la persona mayor dependiente necesita. Finalmente, podemos apreciar cómo la enfermera puede y debe liderar la formación específica de estas personas.

No se ha encontrado ninguna experiencia parecida en la literatura consultada. 


\section{CONCLUSIONES}

\section{El papel de la enfermera en este fenómeno de cuidados se perfila como necesario y beneficioso para todos los implicados en el mismo.}

La información ofrecida por las enfermeras acerca de sus percepciones sobre la cuidadora de ancianos dependientes y sus cuidados, su tratamiento y análisis permite apreciar que la enfermera asume la responsabilidad del cuidado a la persona mayor dependiente y también a su entorno de cuidados. De esta manera, si en dicho entorno se encuentra una cuidadora también ella será responsabilidad de enfermería.

La enfermera pretende llegar a delegar en la cuidadora parte de los cuidados de la persona mayor dependiente y para ello la forma, instruye y trabaja con ella. El modo de llevarlo a cabo está relacionado con tareas como la comunicación, la valoración, observación, anamnesis, consejo, adiestramiento, supervisión o formación, entre otras.

Enfermería es testigo de la situación de estas cuidadoras y la imagen que tiene de ellas corresponde con la ofrecida por el resto de los participantes en este estudio.

La enfermera delega en la cuidadora una vez que está segura de su capacidad, si ésta le transmite tranquilidad y confianza a través de su comportamiento, actitud y saber hacer. La comunicación es considerada un eje principal en el entendimiento entre enfermera y cuidadora.

\section{REFERENCIAS}

[1]. Ballester, L. (2008, Junio). La participación de inmigrantes en el cuidado a los mayores. En Salud Cardiovascular y Envejecimiento Activo. 50 Congreso Nacional de la Sociedad Española de Geriatría y Gerontología y 29ํㅡㄹ Congreso de la Sociedad Andaluza de Geriatría y Gerontología. Granada.

[2]. Benavente, J. (2007). Inmigración y atención a la dependencia. CEDE. En http://www.alares.es/index.php/content/download/957/5763/file/28\%2009\%2007\%20Inmigracióny\%20Atenció n\%20a\%20la\%20Dependencia\%20-\%20CEDE.pdf.

[3]. Bertoldi, S., Fiorito, M.E., \& Álvarez, M. (2006). Grupo focal y desarrollo local: aportes para una articulación teórico-metodológica. Revista Ciencia, Docencia y Tecnología, XVII (033), 111-131.

[4]. Cachón, L. (1995). El marco institucional de la discriminación y tipos de inmigrantes en el mercado de trabajo en España. Revista Española de Investigaciones Sociológicas, 69, 105-124.

[5]. Durán, M.A. (2004). El trabajo no remunerado y las familias. En Cruz, L., (Ed.). España 2015: Prospectiva Social e Investigación Científica y Tecnológica. Fundación Española para la Ciencia y la Tecnología. Recuperado de www.fecyt.es/es/system/files/publications/attachments/.../espana_2015.pdf

[6]. Martín, A., \& Cano, J.F. (2008). Atención primaria. Conceptos, organización y práctica clínica. (6ª̣d.). Madrid: Elsevier.

[7]. Martínez, R. (2006). El cuidado de ancianos: un nicho laboral para mujeres inmigrantes y un reto de gestión para las entidades del tercer sector. Revista Española del Tercer Sector, 4, 99-127.

[8]. Martínez, R. (2007). Bienestar y Cuidados. El oficio del cariño. Mujeres inmigrantes y mayores nativos (Tesis Doctoral). Recuperado de http://migraciones.ugr.es/cddi/index.php/tesis-doctorales/article/395-martinezbujanraquel 


\section{Capítulo 4}

Adaptación del Modelo del Sol Naciente de Leininger a la cuidadora extranjera con el objetivo de determinar los factores culturales que afectan a su labor de cuidar de una persona mayor dependiente

María José Morales-Gázquez

Epifanía Natalia Medina-Artiles

María del Carmen Navarro Rodrígues

María Milagros Torres-Garcia

Carmen Trigueros-Cervantes

Resumen : Objetivo: analizar la influencia cultural en los cuidados a mayores llevados a cabo por inmigrantes. Metodología: Estudio fenomenológico, interpretativo cuyo análisis se basó en la teoría fundamentada. Se realizaron entrevistas en profundidad, autocumplimentadas y grupales a cuidadoras extranjeras, donde se abordaron las dimensiones culturales del Modelo del Sol Naciente de Leininger. Informe resultados: se han encontrado como poco influyentes los factores tecnológicos, económicos y políticos; como influyentes la visión del mundo; y como muy influyentes la etnohistoria, la espiritualidad, los valores y creencias, la educación, y las relaciones sociales y de parentesco. Conclusiones: en el cuidado a mayores llevado a cabo por inmigrantes influyen aspectos culturales y contextuales. Entienden el cuidado como un acto de amor y vocacional y aspectos como la solidaridad intergeneracional y el cuidado ligado al género femenino. No tienen formación adecuada.

Palabras Clave: Ancianos; Cuidadores inmigrantes; cuidados familiares; enfermería transcultural; Cuidados de Enfermería en el Hogar. 


\section{INTRODUCCIÓN}

En el marco de la envejecida población española, no existen respuestas gubernamentales eficaces a la situación de dependencia de cada vez más personas mayores. El estado de bienestar basado en la familia obliga a esta a encontrar una solución a las necesidades del mayor dependiente y a su cuidado. Esta solución la encuentran en la contratación de mujeres extranjeras que puedan realizar los cuidados intensos de la persona dependiente. En este trabajo, apoyado en los preceptos de la Enfermería Transcultural de Madeleine Leininger, nos planteamos la cuestión de si la diferencia cultural entre cuidadora y receptor/a de cuidados influye en la forma en que realizan estos cuidados.

\section{METODOLOGÍA}

Para conseguir responder a la cuestión planteada se ha realizado un estudio fenomenológico de corte interpretativo. Las técnicas de recogida de información empleadas fueron diecinueve entrevistas en profundidad, once entrevistas autocumplimentadas y una entrevista grupal con cuatro participantes. Los participantes fueron cuidadoras extranjeras de personas mayores en domicilio. La selección de las participantes fue realizada mediante muestreo intencionado y nominal o en bola de nieve.

Se abordaron las dimensiones del cuidado cultural propuestas por Leininger en su Teoría de la Diversidad y Universalidad del Cuidado Cultural (TDUCC) y para lo cual se contó con la guía propuesta por la autora en su Modelo del Sol Naciente (MSN) (Leininger, 1995; 2006; 2004).

Teniendo en cuenta que el objetivo de esta guía es permitir a la enfermera realizar una valoración al paciente con el fin de brindarle unos cuidados culturalmente competentes tuvo que adaptarse a los objetivos y circunstancias particulares de nuestra investigación.

Este proceso de adaptación consistió en tres fases. Primero se realizó la identificación comparativa entre los objetivos de las entrevistas en profundidad dentro del marco de la investigación, y los objetivos para los que el MSN fue diseñado, con la finalidad de que sustentara la base de las posteriores decisiones metodológicas. La segunda fase consistió en revisar aquellas dimensiones conceptuales necesarias para mantener el encuadre teórico y metodológico en la TDUCC y el MSN. Para ello se partió de los conceptos del metaparadigma enfermero según se definen en la teoría y se ampliaron a la figura de la cuidadora y al entorno en el que desarrolla su trabajo (Tabla 1). Esta modificación es una adaptación libre, que en nada pretende inferir sobre los conceptos originales de Leininger.

Tabla 1. Proceso de adaptación metodológica a la investigación. Fase 2: Comparación conceptos del metaparadigma

\begin{tabular}{|c|l|l|}
\multicolumn{2}{|c|}{ TDUCC enfocada al paciente } \\
\hline \multirow{2}{*}{ PERSONA } & $\begin{array}{l}\text { Ser humano. Ser cultural. } \\
\text { Receptor de los cuidados } \\
\text { Características dimensionales: } \\
\text { - Paciente } \\
\text { - Pasivo }\end{array}$ & $\begin{array}{l}\text { Ser humano. Ser cultural. } \\
\text { Dadora de cuidados } \\
\text { Características dimensionales: } \\
\text { Trabajadora/cuidadora }\end{array}$ \\
\hline \multirow{2}{*}{ ENTORNO } & $\begin{array}{l}\text { Todos los aspectos contextuales } \\
\text { donde VIVEN las personas }\end{array}$ & $\begin{array}{l}\text { Todos los aspectos contextuales donde las personas REALIZAN } \\
\text { su trabajo de cuidados }\end{array}$ \\
\hline \multirow{2}{*}{ CUIDADO } & $\begin{array}{l}\text { Acciones DIRIGIDAS a mejorar la } \\
\text { situación de las personas } \\
\text { Esencia de la enfermería }\end{array}$ & $\begin{array}{l}\text { Acciones REALIZADAS por la persona y dirigidas a mejorar la } \\
\text { situación de la persona receptora de cuidados }\end{array}$ \\
\hline \multirow{2}{*}{ SALUD } & $\begin{array}{l}\text { Situación definida culturalmente } \\
\text { por la persona } \\
\text { Connotaciones: } \\
\text { La persona define su salud }\end{array}$ & $\begin{array}{l}\text { Situación definida culturalmente por la persoa } \\
\text { Connotaciones: }\end{array}$ \\
\hline
\end{tabular}


La tercera y última fase del proceso consistió en la identificación final de las dimensiones de la investigación, para ello se compararon los objetivos y modos de abordaje propuestos en la guía del MSN con los objetivos perseguidos en nuestra investigación de modo que dicha adaptación garantizara la coherencia epistemológica y metodológica de este estudio.

Los procedimientos de análisis se han llevado a cabo conforme a las propuestas de fragmentación y articulación de la teoría fundamentada (Valles, 2000; Strauss \& Corbin, 2002; Glaser \& Strauss, 1999). Todas las técnicas de obtención de información aquí empleadas, excepto las entrevistas autocumplimentadas, fueron grabadas con el permiso de los participantes, transcritas e importadas al software de análisis de datos cualitativos Nudist NVivo 10.0 en el que se procedió a la codificación, categorización y análisis de la información. Estas fases se llevaron a cabo mediante el método de comparación constante (Glaser \& Strauss, 1999; Strauss \& Corbin, 2002; Valles, 2000).

Los criterios para organizar en primer lugar los datos obtenidos fueron las áreas temáticas presentes en el Modelo del Sol Naciente de Leininger (2006). Tras este proceso, se realizó un análisis sobre los elementos creados. Este tipo de análisis temático consistió en la identificación de aspectos como la frecuencia de aparición de los temas, la variación según los diferentes informantes y según los contextos, así como la interdependencia entre los elementos de los modelos detectados (Escalante \& Páramo, 2011). Tras esta primera categorización, en el resto del proceso se siguió un criterio inductivo.

Tras la codificación y categorización, se realizó un proceso de análisis y agrupamiento seguido de la transformación de los datos, es decir, la expresión de los datos de una nueva forma (Rodríguez et al., 1999; Ruiz, 2003; Strauss \& Corbin, 2002).

Para finalizar se obtuvieron los resultados y las conclusiones, mediante la contextualización y constatación de los hallazgos alcanzados con otros estudios, plasmando todo ello en un informe narrativo.

En esta primera organización significativa la rama Factores Influyentes en el Cuidado fue organizada en base a la guía del MSN, mientras que la rama Prácticas, Expresiones y Patrones de Cuidado (Figura 1) tuvo una organización libre y emergente a partir del discurso de las cuidadoras, por lo que en esta primera fase descriptiva del análisis, quizá el poder acogernos a las temáticas planificadas en la teoría y abordadas en las entrevistas como punto de partida, pudo ayudar en la organización primera de los datos.

Fig. 1. Primer árbol de nodos partiendo del MSN de Madeleine Leininger.

\begin{tabular}{|ll|}
\hline VALORACIÓN MSN & \\
\hline Nombre & Referencias \\
$\boxplus$ FACTORES INFLUYENTES EN EL CUIDADO & 2930 \\
\hline O PRACTICAS, expresiones y patrones de CUIDADO & 1025 \\
\hline
\end{tabular}

Una vez realizada esta primera codificación emergieron nuevas categorías que fueron añadiéndose a las ramas principales del árbol, de manera que el aspecto del árbol fue variando hasta quedar como se muestra en la figura 2 .

Fig. 2. Grandes ramas del árbol de categorías definitivo

\begin{tabular}{|l|l|} 
Nodos \\
Nombre \\
1 01. PRACTICAS DE CUIDADO \\
$\oplus$ 02. FACTORES INFLUYENTES EN EL CUIDADO \\
$1 \mathrm{O}$ 04. PERCEPCIONES DE LA CUIDADORA \\
\hline
\end{tabular}

\section{FACTORES CULTURALES QUE INFLUYEN EN EL MODO DE ENTENDER Y REALIZAR EL CUIDADO}

Las cuidadoras entrevistadas han reconocido como factores poco influyentes en su modo de realizar y entender el cuidado los tecnológicos, por ejemplo, el uso de una grúa para trasladar a un paciente 
inmovilizado «aquello me costaba más entenderlo que si la tuviera yo en las manos. (...) me parece como si fuera un saco de papas, eso subido ahí, no me gusta» (C16); los factores económicos, pues «la cantidad de trabajo es mucho, yo pienso que nadie lo puede pagar, día y noche...» (C4); y los factores políticos, «¿qué te voy a decir de los políticos? ¡Que son unos embusteros, unos mentirosos! le van a quitar la pensioncita... ahora van a rebajar... mire la salud» (C5).

Entienden como factores influyentes en su modo de cuidar la visión del mundo. En este aspecto se ha visto la comparación entre dos mundos, aquel del que vienen y este al que han llegado y los motivos por los cuales quieren permanecer en este país, pues «yo le digo a mi negro que yo de aquí ya no me quiero ir (...), que esto para mí es un paraíso, que esta paz, esta tranquilidad...» (C7).

Aunque los factores más influyentes en su modo de cuidar, según las personas entrevistadas han sido:

La etnohistoria, pues para quien tuvo una infancia difícil «me sentí muy sola, no tenía padre y mi madre trabajaba todo el día, no me sentí cuidada; cuidar de otra persona me hace útil y feliz, me gusta en medio de sus dificultades» (C10). También en los motivos de emigrar para cuidar ancianos, porque "isabes lo que pasa? que se oía tanta cosa que...: "no, es que allí hay un país que... se consigue casa, carro..." y dices, estoy tres años, me hago millonaria y me vuelvo» (EGC1).

Otro factor muy influyente es el de los valores y creencias, y la forma de entender el cuidado como algo femenino pues «de los viejos cuidan las mujeres, un hombre no se mete» (EGC1), así como el respeto al mayor, ya que «a los viejos de acá (en España) les hace mucha falta el amor de los hijos» (C3). Estos valores arraigados en los atributos femeninos del cuidado y que las mujeres latinas representan tan bien pueden conformarse en los motivos por los cuales estas mujeres han tenido tanto éxito en la consecución de su trabajo de cuidados (Escuredo et al., 2013; Galiana-Gómez de Cádiz et al., 2008; Martínez, R., 2009; Martínez et al., 2011; Nogueira \& Zalakain, 2015; Quiñoz \& Albu, 2012; Rogero, 2010).

El parentesco y relaciones sociales, sobre todo en el caso de una trabajadora interna: «mire, es que tengo mi niña aquí, no la he ubicado, no sé... para internarme y dejarla sola otra vez, como estaba allá, como que no me apetece mucho» (C11)

La religión y espiritualidad se han manifestado como de los más influyentes a la hora del deseo y gusto por cuidar de otro, la cuidadora C5 refirió que «si usted tiene un corazón cochino, hablemos en plata blanca, un corazón sucio que no tiene sentimientos, usted no va a entrar a una casa a cuidar de una persona de estas, a brindarle el cariño, a brindarle amor». Mientras que la bibliografía consultada muestra el marcado carácter religioso que la mayoría de las cuidadoras extranjeras presentan, sobre todo en el caso de las latinas (Benavente, 2007; Marcu, 2009; Martínez-Buján, 2008; Ramos et al., 2010), en nuestro estudio han manifestado, además, sus propias interpretaciones sobre la influencia de este factor cultural en la forma en que entienden y realizan el cuidado.

Por último, el factor educación y concretamente se han referido a la falta de formación específica, «porque el enfrentarte a un mundo que tú no conoces... sí hay que tener formación, (...) aunque sea un curso lo más mínimo de primeros auxilios, pero saber... algo, algo...» (C10), llegando incluso problemas para poder asistir a alguna actividad formativa porque «el problema mío sería escribir, claro porque al no saber escribir ¿yo qué voy a hacer?» (C13)

\section{CONCLUSIONES}

Tras este estudio se puede concluir que los factores que influyen en el modo en que las entrevistadas cuidan del anciano dependiente son tanto de tipo cultural como contextual.

En la manifestación de su modo de entender el cuidado, las cuidadoras han mostrado un sistema de creencias basado en diferentes valores. Entre ellos se encuentra el valor de la solidaridad entre generaciones dentro de la familia, entendiendo que a los mayores se les respeta y se les cuida, valores que si bien coinciden con los de las generaciones de más edad de la sociedad de destino no lo hacen con los de las más jóvenes.

Otro valor influyente consiste en su concepción del cuidado ligado al género, considerando cualidades femeninas como la paciencia, el cariño, o la docilidad como las más idóneas para realizar esta labor. Siendo mujeres, perciben como «propias» las tareas domésticas y del cuidado de la persona mayor dependiente y entienden que es la mujer quien cuida, lo que les confiere naturalidad y facilidad para realizar su trabajo de cuidados. Este aspecto coincide con los valores de la sociedad de destino y está en la base de la creencia de que no es necesaria la formación para llevarlos a cabo. 
Aunque a priori tanto la cuidadora como los empleadores coinciden en que la formación no es necesaria para este trabajo por ser considerado por todos ellos como algo natural e intuitivo, pronto estas percepciones cambian, descubriendo que la formación específica es necesaria para que los cuidados sean seguros, eficaces y adecuados.

Algunas de las cuidadoras de este estudio establecen una relación entre el hecho de haber sufrido malos tratos o separación de los padres, siendo niñas con el deseo de cuidar, de demostrar cariño y de sentirse necesarias de adultas. Así, consideran que la relación de ayuda les hace sentirse útiles y satisfechas.

En el ámbito de lo espiritual, la mayoría de las cuidadoras se han reconocido creyentes, aspecto considerado por muchas de gran importancia en sus vidas. Se encomiendan a Dios en las dificultades y piensan que es necesario llevar una vida recta y tener un corazón limpio para brindar cariño, amor y cuidados a otra persona. Han expresado que sus creencias religiosas les ayudan a afrontar las diferentes situaciones humanas que se encuentran en su trabajo de cuidados.

En referencia a los factores tecnológicos, las participantes no manifiestan que tales aspectos contribuyan de manera significativa en su trabajo de cuidados, mostrando algunas, incluso, un rechazo rotundo ante sistemas como los de movilización pasiva. Otras lo consideran positivo, pero sin mostrar gran interés.

Tampoco expresan que los factores económicos influyan en el modo en que realizan los cuidados. Si bien casi todas se sienten mal pagadas, refiriéndose a este aspecto como un posible determinante para continuar o no en ese trabajo, entienden que el mismo no debe condicionar el modo en que cuidan de la persona que tienen a su cargo.

Los factores políticos que las cuidadoras han considerado que influyen en su trabajo son los relacionados con los recursos sociosanitarios contemplados en la ley de dependencia. El Servicio de Ayuda a Domicilio es el recurso más valorado por las cuidadoras, ya que se encarga de realizar el mismo tipo de tareas que ellas, contribuyendo a descargarlas del mismo, algo que también les ocurre en las pocas ocasiones que los receptores de cuidados acuden regularmente a centros de día.

Sin embargo, para entender cómo realizan los cuidados no solamente se tuvo en cuenta sus percepciones, creencias y valores, sino también las relacionadas con los factores contextuales. Las características de intimidad y privacidad, incluso soledad, en que se desarrolla su trabajo confieren invisibilidad a su labor y vulnerabilidad laboral a la cuidadora.

Estas cuidadoras han manifestado que la situación de dependencia en la que se encuentra el receptor de los cuidados, así como su personalidad y patología influyen de manera determinante en el modo de afrontar su trabajo.

\section{REFERENCIAS}

[1]. Escalante, E., \& Páramo, M.A. (2011). Aproximación al análisis de datos cualitativos. Aplicación en la práctica investigativa. Mendoza: Editorial de la Universidad del Aconcagua.

[2]. Escuredo, B., Torres P., Casanovas I., \& Fernández, L. (2013). ¿Cómo perciben los mayores a sus cuidadoras inmigrantes? Sobre la ayuda que necesitan y reciben en el domicilio. Rev ROL Enferm, 36(11), 766-775.

[3]. Galiana-Gómez de Cádiz, M.J., De la Cuesta-Benjumea, C., \& Donet-Montagut, T. (2008). Cuidadoras inmigrantes: características del cuidado que prestan a la dependencia. Enferm Clin, (18), 269-72. Recuperado de http://www.elsevier.es/es-revista-enfermeria-clinica-35-resumen-cuidadoras-inmigrantes-caracteristicas-delcuidado-13126760

[4]. Glaser, B. \& Strauss, A. (1999). The discovery of grounded theory: strategies for qualitative research. New York: Aldine de Gruyer.

[5]. Leininger, M. (1995). Transcultural Nursing. Concepts, Theories, Research y Practices. USA: McGraw-Hill.

[6]. Leininger, M.M. (2004). Leininger's Sunrise Enabler to Discover Culture Care. Recuperado de http://www.madeleine-leininger.com

[7]. Leininger, M.M. (2006). Culture Care Diversity and Universality Theory and Evolution of the Ethnonursing Method. En Leininger, M.M., \& McFarland, M.R. (2006). Culture Care Diversity and Universality. A Worlwide Nursing Theory. (2nd ed.). Sudbury, MA: Jones and Bartlett.

[8]. Martínez, R. (2009a) Inmigración y envejecimiento desde una perspectiva asistencial. Género y Empleo. Madrid: Documentos de Trabajo de la Fundación Carolina, (32), 87-95. Recuperado de http://www.researchgate.net/publication/40224057_Inmigracin_y_envejecimiento_desde_una_perspectiva_asistenci al 
[9]. Martínez, P., Tendero, P., Martínez, L., \& Guijarro, T. (2011). Cuidados extranjerizados a personas mayores en sus hogares de España. Paraninfo Digital. V(14). Recuperado de http://www.index-f.com/para/n14/098o.php

[10]. Nogueira, J., \& Zalakain, J. (2015). La discriminación múltiple de las mujeres inmigrantes trabajadoras en servicios domésticos y de cuidado en la Comunidad Autónoma de Euskadi. Emakunde. Instituto Vasco de la Mujer.

[11]. Quiñoz, M.D., \& Albu, D. (2012). Experiencias del cuidado en las mujeres inmigrantes: Consecuencias para su salud. Paraninfo Digital. Recuperado de http://www.index-f.com/para/n15/038o.php

[12]. Rodríguez, I., \& Gil, P. (2009). Aspectos sociodemográficos y sociales del envejecimiento. En Pérez Melero, A. (Coord.). Enfermería Geriátrica (pp. 29-33). Madrid: Editorial Síntesis.

[13]. Rogero, J. (2010). El impacto de la dependencia de los mayores en la vida cotidiana de sus cuidadores. Madrid: IMSERSO.

[14]. Ruiz, J.I. (2003). Metodología de la investigación cualitativa. Bilbao: Editorial Universidad de Deusto.

[15]. Strauss, A., \& Corbin, J. (2002). Bases para la investigación cualitativa. Técnicas y procedimientos para desarrollar la teoría fundamentada. Medellín, Colombia: Editorial Universidad de Antioquía.

[16]. Valles, M. (2000). Técnicas cualitativas de investigación social. Reflexión metodológica y práctica profesional. Madrid: Síntesis Sociología. 


\section{Capítulo 5}

\section{Pictogramas no processo de cuidado farmacêutico}

\section{Carine Viana Silva}

\section{Letícia Bittencourt Turra}

Resumo: Os pictogramas é uma forma de comunicação visual que utiliza figuras para transmitir informações de forma clara e concisa. Pictogramas podem auxiliar uma parcela da população com déficit de cognição, baixa acuidade visual, analfabetismo e idade avançada que apresentam dificuldades de compreensão da sua farmacoterapia. Os pictogramas podem ser utilizados nas prescrições, embalagens, rótulos e bulas de medicamentos, bem como nas mais diversas formas de passar informações clínicas aos pacientes. No cuidado farmacêutico, podem se consolidar como instrumento facilitador na orientação farmacêutica ao usuário, de forma a reduzir a ocorrência de problemas relacionados à medicamentos e suas inerentes consequências. Estes símbolos gráficos têm como objetivo aumentar o entendimento dos indivíduos sobre informações relacionadas ao uso de medicamentos, porém aspectos culturais e nível de escolaridade fazem com que estas ferramentas necessitem de adaptações às necessidades da população assistida. A utilização das imagens associadas às instruções orais e verbais, auxiliam na assimilação de maneira correta das orientações médicas, amplia a capacidade de compreensão de informações, influenciando diretamente no sucesso do tratamento medicamentoso. Além de aumentar a segurança da farmacoterapia, os pictogramas concedem autonomia aos pacientes no que diz respeito à sua terapia, auxiliando na adesão do tratamento, melhorando o desfecho clinico e o controle adequado de patologias crônicas. 0 baixo grau de adesão à farmacoterapia pode afetar negativamente a evolução clínica do paciente, pode gerar outros problemas de saúde e impactar no aumento do número de hospitalizações/reinternações e sobrecarregar o sistema de saúde.

Palavras-Chave: Pictogramas; Cuidado farmacêutico; Adesão terapêutica; Educação em saúde. 


\section{INTRODUÇÃO}

A adesão terapêutica, bem como a efetividade e a segurança dos medicamentos dependem de uma boa compreensão do paciente sobre a sua farmacoterapia. Na atualidade, um dos maiores problemas de saúde é o uso incorreto de medicamentos com as inerentes consequências ao usuário. Nos diversos cenários de atuação, como em serviços de dispensação, educação em saúde, seguimento farmacoterapêutico, gestão da condição de saúde e conciliação medicamentosa, o farmacêutico é protagonista na garantia do uso seguro de medicamentos.

A falta de adesão ao tratamento está fortemente relacionada ao não entendimento parcial ou total da maneira adequada do cumprimento da terapia medicamentosa. Diversos fatores corroboram para esta problemática, os quais podemos destacar critérios como analfabetismo, dificuldade de cognição, idade avançada, baixa acuidade visual e ainda transtornos mentais. Além destes fatores, a relação médicopaciente é fundamental para o cumprimento da farmacoterapia. No entanto, o serviço de saúde pouco desenvolvido e a sobrecarga de trabalho dos profissionais de saúde, com consequente redução no tempo nas consultas e na atenção destinada aos pacientes, se destacam entre os fatores que afetam o entendimento e a adesão à terapia medicamentosa.

Transmitir orientações de forma apropriada, propicia ao usuário o desenvolvimento de autonomia e de responsabilidade pelas decisões diárias que envolvem a sua terapia medicamentosa, como o uso correto e a efetiva a adesão à terapia. Além da comunicação verbal e escrita, os profissionais de saúde podem usar ferramentas didáticas, como imagens e símbolos, para promover um entendimento eficaz sobre o uso dos medicamentos. Os pictogramas representam uma forma de comunicação a qual utiliza de figuras no intuito de transmitir informações de forma clara e concisa. Contudo, aspectos culturais e nível de escolaridade fazem com que estas ferramentas necessitem de adaptações para as necessidades da população assistida (GALATO et al., 2006; FIP, 2021).

0 texto escrito ou falado acompanhado de imagens possui melhor assimilação que o texto sem figuras, em decorrência do chamado "efeito pictórico superior". Os pictogramas contribuem para a recordação das informações e se revelam eficientes para o aperfeiçoamento da memória (MEDEIROS et al., 2011). Os pictogramas são mensagens expressas de forma simplificada, de fácil entendimento, que proporcionam melhor resolutividade da comunicação visual, sem perder o significado essencial do que se está representando, se tornando uma simbologia de utilidade pública. Ao transmitirem informações, instruções, advertências e prescrições por meio de figuras de fácil entendimento, se consolidam como linguagem alternativa essencial a uma comunicação efetiva.

Segundo o Sistema Nacional de Informações Tóxico-Farmacológicas (SINITOX), cerca de $27 \%$ das ocorrências de intoxicações são causadas pelo uso indevido de medicamentos (BRASIL, 2017). Estudos indicam que a implantação de pictogramas em prescrições médicas e em rótulos de medicamentos está relacionada a um aumento da adesão à farmacoterapia e da compreensão de receituários, evitando a utilização de forma inadequada (SAUSEN, CASTRO, BAYER 2021).

Diante dos fatos apresentados, apresentamos os pictogramas como ferramenta de comunicação complementar às informações verbais e escritas de forma a facilitar o uso de medicamentos, evitar erros e favorecer a efetividade e segurança dos medicamentos.

\section{ADESÃO E COMPREENSÃO DA TERAPIA MEDICAMENTOSA}

Adesão à farmacoterapia é definida como a utilização de pelo menos $80 \%$ do total dos medicamentos prescritos, observando fatores como horário, dose e duração do tratamento (ARRUDA et al., 2015). A adesão ao tratamento é a uniformidade entre as ações do paciente e as orientações do profissional de saúde responsável pelo tratamento. 0 baixo grau de adesão pode afetar negativamente a evolução clínica do paciente, impactar no aumento do número de hospitalizações/reinternações e sobrecarregar o sistema de saúde (TAVARES et al. 2013). Dentre os fatores que impedem a sequência do tratamento medicamentoso, destacam-se o analfabetismo, problemas visuais ou auditivos, a incompreensão da prescrição e das informações prestadas pela equipe de saúde. 
0 analfabetismo é um problema presente na vida de milhões de brasileiros. A taxa de analfabetismo no Brasil caiu de 7,2\% para 6,6\% da população, entre os anos de 2016 e 2019, porém este número ainda representa aproximadamente 13,9 milhões de pessoas (IBGE, 2021). 0 analfabetismo é um dos exemplos mais graves de exclusão educacional e social. Esta exclusão social baseia-se não somente em relações interpessoais, mas também em tarefas simples do dia a dia como entender um cartaz, um anúncio e inclusive uma prescrição médica (PERES, 2011).

A estimativa é que $15,7 \%$ da população brasileira possua idade igual ou superior a 60 anos, são 33,1 milhões de indivíduos (IBGE, 2021) que representam parcela significativa dentre os usuários de medicamentos. Pessoas em idade avançada com a cognição afetada podem ter dificuldades no processamento de informações, quando demonstradas de forma rápida ou com pouca clareza. Outra questão relacionada à idade é a redução gradual da elasticidade do cristalino, com consequente prejuízo na visão. A relação entre estes fatos destaca a importância do uso de pictogramas apresentados de forma clara e precisa, juntamente com as informações verbais e escritas.

A evolução clínica do paciente e, consequentemente, sua qualidade de vida pode ser prejudicada por uma perda de adesão à terapia medicamentosa causada por falhas de comunicação entre profissionais da saúde e pacientes. A conduta clínica dos profissionais de saúde deve ter como base a escuta e o diálogo, preocupando-se com o bem estar de seus pacientes, sendo imprescindível a comunicação bem definida pois dúvidas remanescentes ou falta de informações acarretam em uma baixa adesão ao tratamento.

Diante dos fatos expostos e às dificuldades encontradas diariamente por pessoas com estas condições, no que diz respeito à compreensão de prescrições, periodicidade e modo de utilização do medicamento, surgem os pictogramas como meio direcionador do atendimento do profissional da saúde. Transmitir informações adequadamente, considerando a condição de cada indivíduo, propicia o desenvolvimento de autonomia e de responsabilidade pelas decisões diárias que envolvem a sua terapia medicamentosa, como o uso correto e a efetiva a adesão à terapia.

\section{USO PICTOGRAMAS NO PROCESSO DE CUIDADO FARMACÊUTICO}

O cuidado farmacêutico se materializa na prestação de serviços farmacêuticos que se caracterizam pela capacidade desse profissional em identificar, prevenir e resolver problemas relacionados à farmacoterapia. A responsabilidade inerente ao farmacêutico é garantir que os medicamentos utilizados sejam efetivos e seguros, além de educar o paciente para que este seja capaz de utilizá-los adequadamente e com adesão à farmacoterapia prescrita. Nesta perspectiva, os pictogramas se consolidam como ferramentas didáticas principalmente na prestação de serviços como educação em saúde, dispensação orientada de medicamentos e acompanhamento farmacoterapêutico (BRASIL, 2016).

Os pictogramas são símbolos gráficos que auxiliam no entendimento dos usuários sobre informações relacionadas ao uso de seus medicamentos. Como podem amplificar o significado da língua falada, funcionam como um sistema adicional de comunicação visual (GALATO et al., 2006; FIP 2021). Estas figuras representadas de forma clara e estruturada são utilizadas em diversas situações, a fim de desenvolver, incrementar e fortalecer a linguagem falada cumprindo assim um importante papel de utilidade pública (MATOS, 2009).

A dispensação farmacêutica tem por finalidade propiciar o uso adequado e seguro do medicamento, uma vez que além de entregar o medicamento, o profissional deve garantir condições para que o paciente o consuma de maneira adequada (BRASIL, 2016). Os pictogramas como estratégia educativa podem contribuir para aumentar conhecimentos, desenvolver habilidades e responsabilidades sobre a sua própria farmacoterapia com aumento do seu grau de comprometimento. A principal ferramenta no processo de cuidado farmacêutico é a informação. A utilização de imagens como meio de comunicação amplia a capacidade de compreensão de informações, influenciando diretamente no sucesso do tratamento medicamentoso. As informações contidas nas embalagens, rótulos, bulas e em prescrições de medicamentos também auxiliam no uso seguro dos medicamentos. 
A Anvisa veda a impressão na embalagem de símbolos, figuras ou representações gráficas que proporcionem interpretação falsa, equívoco ou erro em relação à verdadeira natureza, composição, forma de uso, finalidade e características do medicamento (BRASIL, 2009b). No entanto, alguns pictogramas que são obrigatórios em embalagens de medicamentos. Como exemplo, o Ministério da Saúde determina que medicamentos contendo substâncias retinóicas deverão conter na embalagem em destaque o símbolo de uma mulher grávida dentro de um círculo cortado ao meio. Justaposto a este pictograma, devem contar as expressões "Atenção: Uso sob prescrição médica" e "Atenção: riscos para mulheres grávidas". Este mesmo símbolo deve estar também impresso nas notificações de receitas entregues aos pacientes para aquisição do medicamento (BRASIL, 1998).

A indústria responsável pelo medicamento deve prestar as informações obrigatórias sobre possíveis problemas relacionados ao consumo do produto em uma linguagem acessível para todos os públicos. A Agência Nacional de Vigilância Sanitária (Anvisa) delibera que a bula é um documento legal sanitário que deve possuir informações técnico-científicas que norteiem o uso seguro dos medicamentos (BRASIL, 2009a). As bulas destinadas ao paciente devem orientar sobre os medicamentos, mas em linguagem apropriada e de fácil compreensão. A exemplo, as bulas devem ser disponibilizadas em áudio ou dispostas em Braille para as pessoas portadoras de deficiência visual. Embalagens também devem conter o sistema Braille não afetando na compreensão das informações (BRASIL, 2009b). No Brasil, algumas bulas de medicamentos possuem pictogramas, mas devido a não padronização das instruções visuais as imagens apresentam deficiência quanto à legibilidade (MEDEIROS et al., 2011). As maiores propensões de ocorrerem interpretações incorretas em bulas de medicamentos se dá em pessoas com baixo nível de escolaridade (SOARES, 2013).

Neste contexto, os pictogramas aplicados à área farmacêutica tonam-se pauta de discussão em diversos órgãos nacionais e internacionais com a finalidade de propagar sua padronização e utilização como forma de prevenir problemas relacionados a medicamentos. De acordo com a Farmacopeia Americana (USP, do inglês United States Pharmacopeia), os pictogramas podem ser definidos como universalização da língua e auxiliam na transmissão de instruções, precauções e advertências de medicamentos, os quais, são essenciais para propagar conhecimento à pacientes com baixo nível de letramento (USP, 2021). Na prática do cuidado farmacêutico, os principais são os pictogramas de precauções de uso do medicamento, os pictogramas posológicos, os pictogramas de forma de uso e vias de administração.

A USP disponibilizou 81 pictogramas padronizados e concede licença para uso, desde que não sofram modificações e a propriedade da USP seja indicada (direitos autorais). Pictogramas apresentam potencial para interpretação incorreta, uma vez que cada indivíduo pode apresentar uma reação diferente. Desta forma, a Farmacopeia Americana não indica os pictogramas como única forma de transmissão de informações sobre a farmacoterapia do paciente. A permissão de uso pode ser retirada, se considerado que seus pictogramas estejam sendo usados de forma inadequada (USP, 2021).

No Japão, o Risk-Benefit Assesment of Drugs desenvolveu 51 pictogramas em cinco idiomas diferentes transmitindo informações relativas à administração segura de medicamentos (RAD-AR, 2021). As imagens contêm orientações referentes ao horário de ingestão, a via de administração, contraindicações e advertências relativas a medicamentos. Os pictogramas foram criados para serem compreensíveis por todos, independentemente da idade. Além disso, o objetivo desta organização é transformar os pictogramas em figuras tão comuns quanto os sinais de trânsito (MEDEIROS et al., 2011).

A International Pharmaceutical Federation (FIP) também colocou em pauta a comunicação adequada dos profissionais de saúde com os pacientes sobre a sua terapia medicamentosa. A entidade desenvolveu pictogramas no intuito de proporcionar um meio eficaz de transmitir informações aos usuários, além de instruções dos fatores que influenciam interpretações quando utilizados em lugares com culturas diferentes. Segundo a FIP, pictogramas devem formar uma história e por isso disponibiliza um programa onde é possível construir um documento para impressão com todas as informações que o paciente precisa para sua correta farmacoterapia (FIP, 2021).

No Brasil, o Conselho Regional de Farmácia do Estado do Paraná (CRF-PR), padronizou 54 pictogramas para a área da saúde e disponibilizou à comunidade para uso na orientação ao uso de medicamentos (BRASIL, 2017). O projeto da entidade profissional farmacêutica é de grande relevância, já que considera padrões culturais brasileiros. Todavia, com a dimensão do país é importante que os farmacêuticos estejam atentos as diferentes interpretações regionais. 
A legibilidade dos pictogramas está diretamente relacionada ao nível de escolaridade, idade e frequência de uso de medicamentos. 0 uso de pictogramas já validados mitiga o risco de ocasionar falhas de entendimento, já que foram submetidos a análises e testes prévios de legibilidade de acordo com as normativas referenciadas. Entretanto, para garantir a eficácia dos pictogramas é aconselhável testar a compreensão dos pictogramas pelos pacientes antes de usar na prática clínica, mesmo os símbolos já validados (SOARES, 2013). A normativa ISO 3864:2013 estabelece como pictogramas compreensíveis aqueles que atingirem 67\% de acerto na amostra pesquisada (ABNT, 2013), todavia há uma margem significativa para más interpretações.

A capacidade de assimilação das informações demonstradas em figuras é maior em relação àquelas expressas em texto (NETO et. al, 2018). Corroborando com isto, pode-se citar o estudo de Matos (2009) que verificou a utilização das imagens associadas às instruções orais e verbais, visando ajudar na captação das informações médicas, aumentando assim a compreensão da instrução apresentada e auxiliando a seguir as orientações médicas de maneira correta.

A inserção do farmacêutico no atendimento clínico ao paciente no âmbito do Sistema Único de Saúde (SUS), trabalhando de forma integrada à equipe, pode garantir melhoria no processo de uso de medicamentos. A implantação do cuidado farmacêutico no município de Curitiba (PR) aumentou a adesão ao tratamento em mais de $60 \%$ dos pacientes (BRASIL, 2015). Na esfera pública, os pictogramas na orientação farmacêutica podem se consolidar como ferramentas complementares aos meios de comunicação em saúde já existentes. Haja visto que a inserção de pictogramas em materiais informativos influencia na efetividade do tratamento e no uso seguro dos medicamentos, seu uso pode gerar diminuição dos gastos desnecessários ao sistema público de saúde (NETO et. al, 2018).

$\mathrm{Na}$ prática do cuidado farmacêutico, os principais são os pictogramas de precauções de uso do medicamento, os pictogramas posológicos, os pictogramas de forma de uso e vias de administração. A Figura 1 apresenta exemplos comparativos entre os pictogramas da Farmacopeia Americana (USP, 2021), International Pharmaceutical Federation (FIP, 2021) e do o Conselho Regional de Farmácia do Estado do Paraná (BRASIL, 2021). A Figura 2 apresenta um exemplo de um calendário posológico criado a partir do programa PictoRx® disponibilizado pela International Pharmaceutical Federation (FIP, 2021). 0 recurso eletrônico apresenta uma série de vantagens, pois é gratuito, apresenta facilidade no uso e possui campos editáveis para inserir comentários sobre cada paciente. 0 programa possibilita quatro formatos de material para impressão: etiquetas; guia pictográfico de cada medicamento; folheto de instruções; e o calendário posológico.

\section{CONCLUSÃO}

Os pictogramas auxiliam no uso seguro de medicamentos através da exibição de imagens em prescrições, embalagens rótulos ou bulas de medicamentos. A utilização das imagens associadas às instruções orais e verbais, auxiliam na assimilação de maneira correta das orientações médicas. Há uma parcela da população que carece de orientações detalhadas das recomendações em relação ao uso correto de medicamentos, de forma a reduzir a ocorrência de problemas relacionados à medicamentos e suas consequências. Além de aumentar a segurança da farmacoterapia, os pictogramas concedem autonomia aos pacientes no que diz respeito à sua terapia, auxiliando na adesão do tratamento, melhorando o desfecho clinico e o controle adequado de patologias crônicas. 
Figura 1: Exemplos de pictogramas da Farmacopeia Americana (USP, 2021), International Pharmaceutical Federation (FIP, 2021) e do o Conselho Regional de Farmácia do Estado do Paraná (BRASIL, 2021).

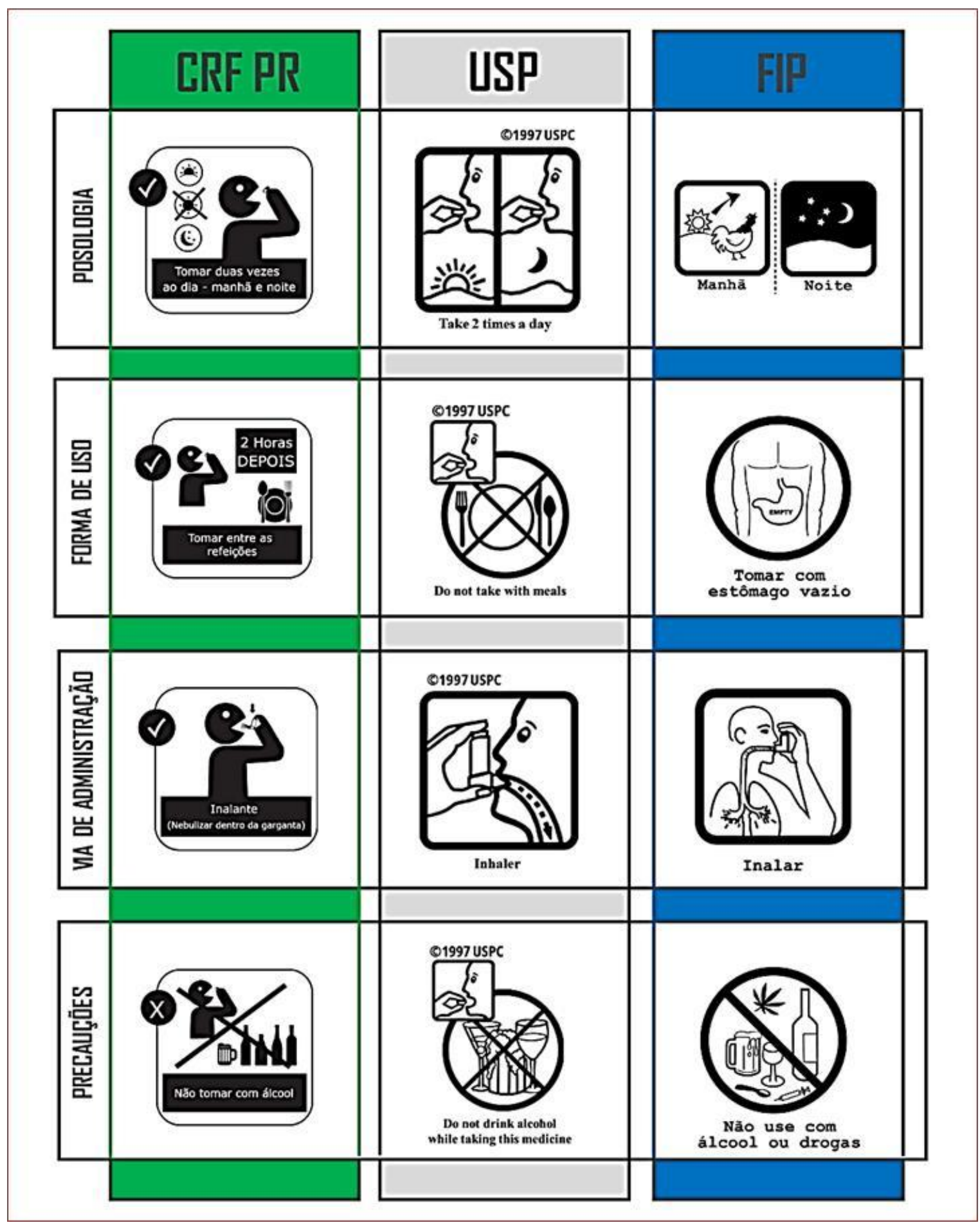

Fonte: Autora, adaptado de USP, 2021; BRASIL, 2021; FIP, 2021. 
Figura 2: Exemplo de calendário posológico criado a partir do programa PictoRx® disponibilizado pela International Pharmaceutical Federation (FIP, 2021).

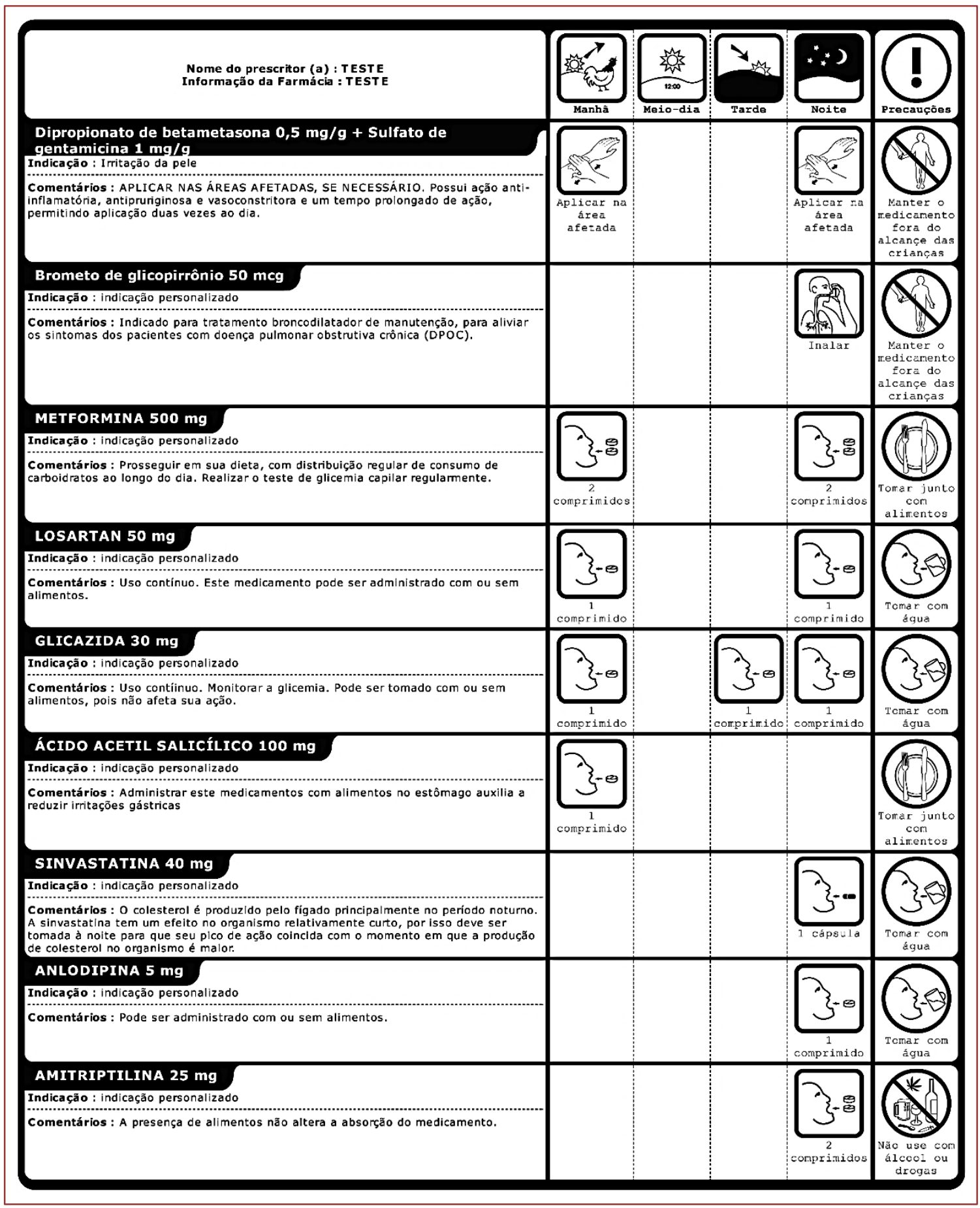

Fonte: Autora, criado a partir do aplicativo PictoRx® (FIP, 2021). 


\section{REFERÊNCIAS}

[1]. ARRUDA DCJ et al. Fatores associados à não adesão medicamentosa entre idosos de um ambulatório filantrópico do Espírito Santo. 18(2):327-337, 2015. Revista Brasileira de Geriatria e Gerontologia. 2015. DOI: 10.1590/1809-9823.2015.14074.

[2]. ASSOCIAÇÃO BRASILEIRA DE NORMAS TÉCNICAS (ABNT). Norma ISO 3864 de 11 de setembro de 2013. Disponível em: < https://www.abntcatalogo.com.br/norma.aspx?ID=304412> Acesso em 01 de setembro de 2021.

[3]. BRASIL. Agência Nacional de Vigilância Sanitária (Anvisa). Resolução RDC no 71, de 22 de dezembro de 2009. Estabelece regras para a rotulagem de medicamentos. 2009b. Disponível em: <https://bvsms.saude.gov.br/bvs/saudelegis/anvisa/2009/res0071_22_12_2009.html>. Acesso em 01 de setembro de 2021.

[4]. BRASIL. Conselho Federal de Farmácia. Serviços farmacêuticos diretamente destinados ao paciente, à família e à comunidade contextualização e arcabouço conceitual. 2016. Disponível em: <https://www.cff.org.br/userfiles/Profar_Arcabouco_TELA_FINAL.pdf> Acesso em 01 de setembro de 2021.

[5]. BRASIL. Conselho Regional de Farmácia do Estado do Paraná. Pictogramas para medicamentos. Disponível em: https://crf-pr.org.br/uploads/pagina/29678/IIDpT_EiTEKEmLFOnKYWHuG-OHTKWROW.pdf Acesso em 01 de setembro de 2021.

[6]. BRASIL. Ministério da Saúde. Fundação Oswaldo Cruz. Sistema Nacional de Informações TóxicoFarmacológicas (SINITOX). Casos, Óbitos e Letalidade de Intoxicação Humana por Agente e por Região. Brasil, 2017. Disponível em: https://sinitox.icict.fiocruz.br/sites/sinitox.icict.fiocruz.br/files//Brasil3_1.pdf Acesso em 01 de setembro de 2021.

[7]. BRASIL. Ministério da Saúde. Secretaria de Ciência, Tecnologia e Insumos Estratégicos. Departamento de Assistência Farmacêutica Insumos Estratégicos. Resultados do projeto de implantação do cuidado farmacêutico no Município de Curitiba. Cuidado farmacêutico na atenção básica, Caderno 4. Brasília, 2015. 100 p. Disponível em: https://bvsms.saude.gov.br/bvs/publicacoes/cuidado_farmaceutico_atencao_basica_saude_4_1ed.pdf Acesso em 01 de setembro de 2021.

[8]. BRASIL. Ministério da Saúde. Secretaria de Vigilância em saúde. Portaria nº 344, de 12 de maio de 1998. Regulamento Técnico sobre substâncias e medicamentos sujeitos a controle especial. Disponível em: https://bvsms.saude.gov.br/bvs/saudelegis/svs/1998/prt0344_12_05_1998_rep.html Acesso em 01 de setembro de 2021.

[9]. GALATO F et al. Desenvolvimento e validação de pictogramas para o uso correto de medicamentos: Descrição de um estudo-piloto. Acta Farmaceutica Bonaerense, 25: 131-138, 2006. Disponível em:

http://www.latamjpharm.org/trabajos/25/1/LAJOP_25_1_4_2_839R009BUN.pdf Acesso em 01 de setembro de 2021.

[10]. INSTITUTO BRASILEIRO DE GEOGRAFIA E ESTATÍSTICA. Painel de indicadores. Analfabetismo. Disponível em: <https://www.ibge.gov.br/indicadores.html>. Acesso em 01 de setembro de 2021.

[11]. INTERNATIONAL PHARMACEUTICAL FEDERATION/FÉDÉRATION INTERNATIONALE PHARMACEUTIQUE (FIP). Projeto de Desenvolvimento de Pictogramas da FIP. Disponível em: https://www.fipfoundation.org/pictograms-download/ Acesso em 01 de setembro de 2021.

[12]. MATOS C. Pictogramas e seu uso nas instruções médicas: estudo comparativo entre repertórios para instruções de uso de medicamentos. Dissertação de Mestrado. São Paulo: Escola de Comunicações e Artes/USP; 2009. $176 \mathrm{p}$.

[13]. MEDEIROS GCR et al. Pictogramas na orientação farmacêutica: um estudo de revisão. Revista Brasileira de Farmácia. 92:96-103, 2011.

[14]. PERES MAC. Velhice e analfabetismo, uma relação paradoxal: a exclusão educacional em contextos rurais da região nordeste. Revista Sociedade e Estado. 26:631-661, 2011. DOI: 10.1590/S0102-69922011000300011

[15]. RAD-AR (Risk-Benefit Assessment of Drugs, Analysis \& Response), 2010. Disponível em: http://www.radar.or.jp/02/08_pict/08_pict_dl.html. Acesso em 01 de setembro de 2021.

[16]. SAUSEN BP, CASTRO AF, BAYER VML. Pictogramas na assistência farmacêutica: uma revisão sistemática. Revista Saúde (Santa Maria). 47: e632542021. D0I: 10.5902/2236583463254

[17]. SOARES MA. Legibility of USP pictograms by clients of community pharmacies in Portugal. Int J Clin Pharm. 35, 22-29 (2013). DOI: 10.1007/s11096-012-9698-z.

[18]. TAVARES NUL et al. Fatores associados à baixa adesão ao tratamento medicamentoso em idosos. Rev Saúde Pública. 47(6):1-9, 2013. DOI: 10.1590/S0034-8910.2013047004834

[19]. USP (United States Pharmacopeia). 2021. Disponível em: <https://www.usp.org/health-quality-safety/usppictograms> Acesso em 01 de setembro de 2021. 


\title{
Capítulo 6
}

\section{Produção de vídeos didático-pedagógicos para o canal Remov Online}

\author{
Gustavo Simão Moraes \\ Fabio Brasil de Oliveira \\ Rosana Marques Silva Figuerôa \\ Alfonso Sánchez-Ayala \\ Nara Hellen Campanha Bombarda \\ Vanessa Migliorini Urban
}

Resumo: As tecnologias de informação e comunicação têm sido cada vez mais incorporadas ao campo educacional. Vídeos instrucionais têm sido utilizados como ferramenta educativa há anos, podendo apresentar maior efetividade no ensino de práticas clínicas do que demonstrações tradicionais. Ainda, os vídeos podem ser revistos conforme as necessidades de quem os assiste, otimizando o tempo nas salas de aula. Recentemente, houve uma reformulação do Projeto Pedagógico do Curso de Odontologia da Universidade Estadual de Ponta Grossa (UEPG), que reduziu a carga horária do Eixo de Reabilitação Oral. Somado a isso, a condição excepcional de pandemia pela COVID-19 tornou imprescindível a inovação e a criatividade na Educação, visando atender os objetivos de aprendizagem e o desenvolvimento das competências e habilidades nos estudantes durante o ensino em modo remoto. Considerando a necessidade de melhor aproveitamento do tempo em sala de aula e a modernização do ensino, o presente Projeto propôs-se a desenvolver um material didático-pedagógico na forma de vídeos, abordando as técnicas utilizadas para a confecção de próteses totais. Estes vídeos foram disponibilizados aos alunos de Odontologia da UEPG e publicados de forma gratuita na Internet. Esse Projeto almejou otimizar o desenvolvimento das atividades das disciplinas do Eixo de Reabilitação Oral, bem como contribuir para o aprendizado de acadêmicos, Técnicos em Prótese Dental e CirurgiõesDentistas, difundindo a filosofia preconizada pelos docentes da Universidade. 0 presente Capítulo tem como objetivo descrever o processo de criação desse material didático-pedagógico.

Palavras-chave: Filmes e vídeos educativos. Recursos audiovisuais. Educação em Odontologia. Prótese dentária. 


\section{INTRODUÇÃO}

A atual grade curricular do curso de Odontologia da Universidade Estadual de Ponta Grossa (UEPG) dispõe de uma carga horária de 68 horas para a disciplina de Prótese Removível pré-clínica, compreendendo aulas teóricas e práticas tanto de Prótese Total como de Prótese Parcial Removível. Devido ao vasto conteúdo da disciplina e às longas demonstrações práticas, muitos alunos não conseguiam concluir seus trabalhos durante as aulas laboratoriais, precisando então terminá-los em horários alternativos. Tendo em vista essas dificuldades e limitações, propôs-se desenvolver um material didático para otimizar as aulas práticas da disciplina. Segundo estudos na área de Prótese Removível e Reabilitação Oral, materiais didáticos, tais como demonstrações gravadas em vídeo e programas interativos, podem ser tão úteis quanto demonstrações realizadas ao vivo, desde que o material seja cuidadosamente produzido (LECHNER et al., 2001; PACKER et al., 2001). Vídeos instrucionais têm sido utilizados como uma ferramenta educativa por apresentarem maior efetividade no ensino de práticas clínicas do que demonstrações tradicionais (SHAH et al., 2016).

Anteriormente à crise humanitária sem precedentes provocada pela pandemia da COVID-19, as tecnologias de informação e comunicação já vinham sendo incorporadas ao campo educacional gradativamente (MARSON \& DOS SANTOS, 2010). Excepcionalmente, no contexto pandêmico, o Ministério da Educação (MEC) e o Conselho Nacional de Educação (CNE) publicaram em março de 2020 um documento Proposta de parecer sobre reorganização dos calendários escolares e realização de atividades pedagógicas não presenciais durante o período de pandemia da COVID-19 (MEC, 2020). Segundo o documento, haveria um desafio significativo, neste caso para o ensino superior, quanto à forma como o calendário escolar (de 2021 e, eventualmente, de 2022) deveria ser reorganizado. Salientando a manifestação do CNE, deveria ser assegurado que durante a reposição de aulas e de atividades fosse preservado o padrão de qualidade previsto no inciso IX do artigo 3 o da LDB (Lei de Diretrizes e Bases da Educação Nacional) e inciso VII do artigo 206 da Constituição Federal. Ainda, em julho de 2020, a Associação Brasileira de Ensino em Odontologia (ABENO) publicou o e-book Consenso ABENO: biossegurança no ensino odontológico pós-pandemia da COVID-19. Neste livro, foi recomendada a realização de demonstrações por meio de sistemas de vídeo e projeção, evitando aglomerações em salas de aula (PIRES \& FONTANELLA, 2020).

Com isso, o presente Projeto foi desenvolvido com o objetivo de produzir vídeos educativos abrangendo o Programa da disciplina para permitir que os alunos aprendessem de forma autônoma. Esperava-se, dessa maneira, que a necessidade de demonstrações durante as aulas práticas fosse reduzida, proporcionando mais tempo em sala de aula para que os alunos realizassem suas tarefas com a supervisão dos docentes. Esse material também poderia auxiliar na fixação dos conteúdos abordados nas aulas teóricas e serviria como revisão para os alunos que foram aprovados e já passaram pela disciplina pré-clínica.

Os vídeos didático-pedagógicos produzidos durante a execução do presente Projeto foram disponibilizados de forma gratuita na Internet, por meio da criação de um canal em mídia social. Dessa forma, estudantes e professores de Odontologia de qualquer Instituição do país e até mesmo profissionais Cirurgiões-Dentistas, Auxiliares em Saúde Bucal, Técnicos em Saúde Bucal e Técnicos em Prótese Dental também puderam ser beneficiados com o conteúdo criado. Pelo fato de se tratar de Produção Técnica com um amplo alcance social, desenvolvida por alunos e professores do Programa de Pós-Graduação em Odontologia, contribuições serão geradas na valorização frente a Coordenação de Aperfeiçoamento de Pessoal de Nível Superior (CAPES), que propõe, dentre os novos indicadores e perspectivas futuras da área de Odontologia para a avaliação quadrienal dos Programas de Pós-Graduação, o planejamento de ações de extensão, solidariedade e inserção social que originem produção científica e técnica qualificada e principalmente impacto loco-regional.

O presente capítulo descreve todo o processo de produção desses vídeos, partindo-se desde a captura de imagens (filmagens e fotografias), até o momento de edição, pós-produção e renderização.

\section{MATERIAL E MÉTODOS}

Todo o material capturado para a produção dos vídeos ou fotografias das demonstrações práticas de Prótese Total foi obtido entre os anos de 2018 e 2019, anteriormente à pandemia da COVID-19, nas dependências do Bloco M da UEPG. Foram utilizadas câmeras do tipo DSLR (Canon Rebel EOS T1i, Canon Rebel EOS T5 e Canon EOS 7D Mark II; Canon Inc., NY, EUA) e suas respectivas lentes (Lente EF 100mm f/2.8 Macro USM, Lente EF $100 \mathrm{~mm}$ f/2.8L Macro IS USM e Lente EF 50mm f/1.8 STM; Canon Inc.). Também se fez necessária a utilização de iluminação apropriada para a captura dos vídeos, a partir do uso 
de um kit de iluminação Softbox (ZCOD; Eletrônicos Ltda., SC, Brasil) e para as fotos, um flash circular para fotografias macro (Macro Ring Lite YN-14EX; YongNuo Photographic Equipment Co., Ltd., HK, CN) e um flash twin (Macro Twin Lite MT-24EX; Canon Inc.) (Figura 1).

Figura 1 - Equipamentos utilizados para a gravação dos vídeos e obtenção das fotografias para o material didático de Prótese Total

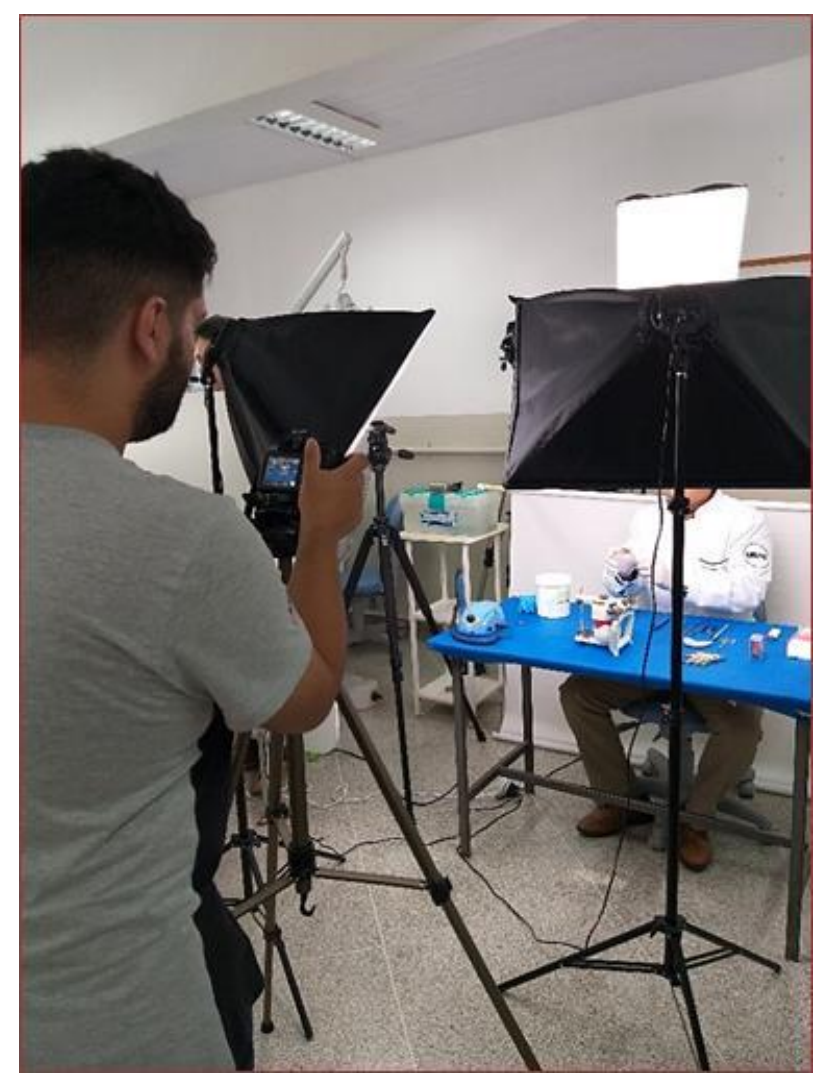

É possível observar duas câmeras montadas em tripés, o kit de iluminação Softbox e o banner utilizado como fundo. Filmagem feita anteriormente à pandemia da COVID-19.

Participaram desse Projeto quatro alunos de Graduação, quatro alunos de Pós-Graduação e quatro professores do eixo de Reabilitação Oral da UEPG (Figura 2). Durante as gravações, a equipe executora utilizou equipamentos de proteção individual (EPIs) e realizou os procedimentos de confecção de Prótese Total simulados em manequim (já que atenderiam à disciplina de prática operatória - laboratorial), conforme preconizado pelos docentes da Universidade (Figura 3). 0 armazenamento dos arquivos obtidos foi feito em dois HDs externos (HD Seagate Expansion Portátil 2tb; Seagate Technology, CA, EUA). 
Figura 2 - Parte da equipe de professores e alunos do Eixo de Reabilitação Oral da UEPG

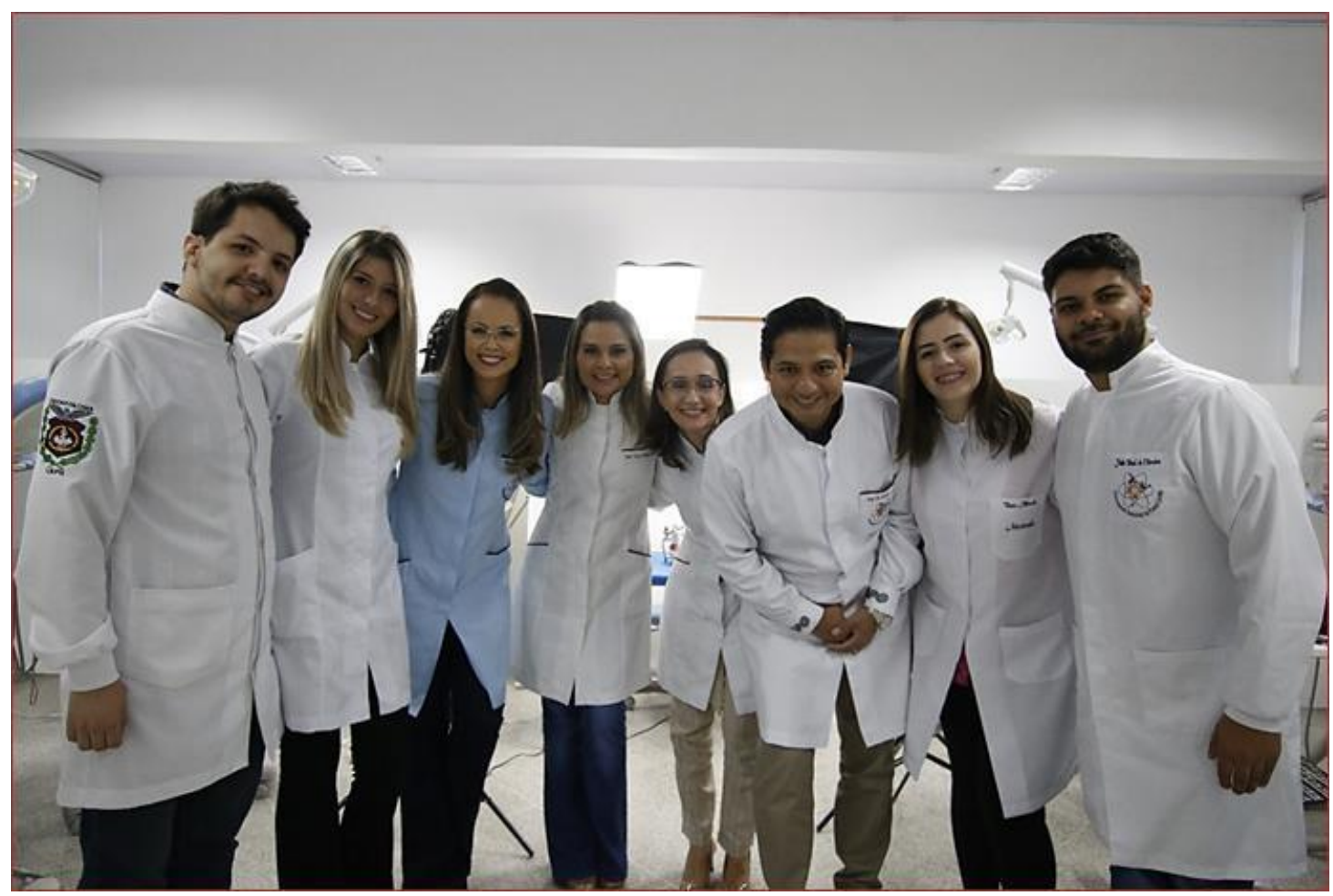

Fotografia feita anteriormente à pandemia da COVID-19.

Figura 3 - Filmagem da montagem de dentes artificiais para a confecção de Prótese Total

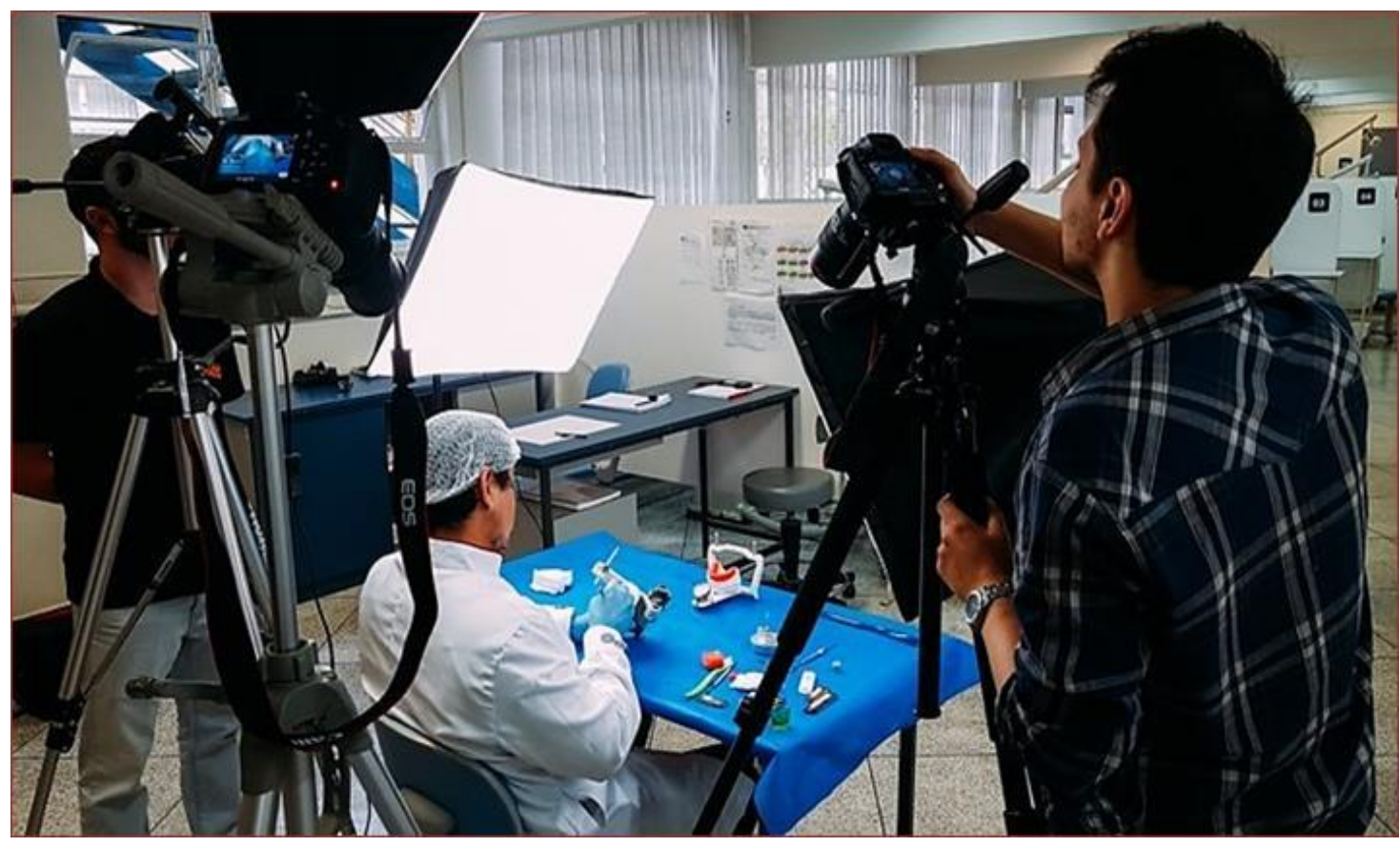

A figura demonstra como foi montado o setup para as filmagens dos procedimentos de confecção de Prótese Total. Filmagem feita anteriormente à pandemia da COVID-19.

Em paralelo às gravações, os participantes elaboraram textos para serem narrados durante a exibição dos vídeos (Figura 4). 0 áudio de alguns desses textos foi captado utilizando a interface de áudio Yamaha (modelo AG03) e um microfone (modelo shure sv200), e a gravação foi feita no software Logic Pro X (Apple Inc., CA, EUA) (Figura 5). 
Figura 4 - Elaboração dos textos descrevendo os procedimentos realizados nos vídeos de Prótese Total para a posterior gravação da narração

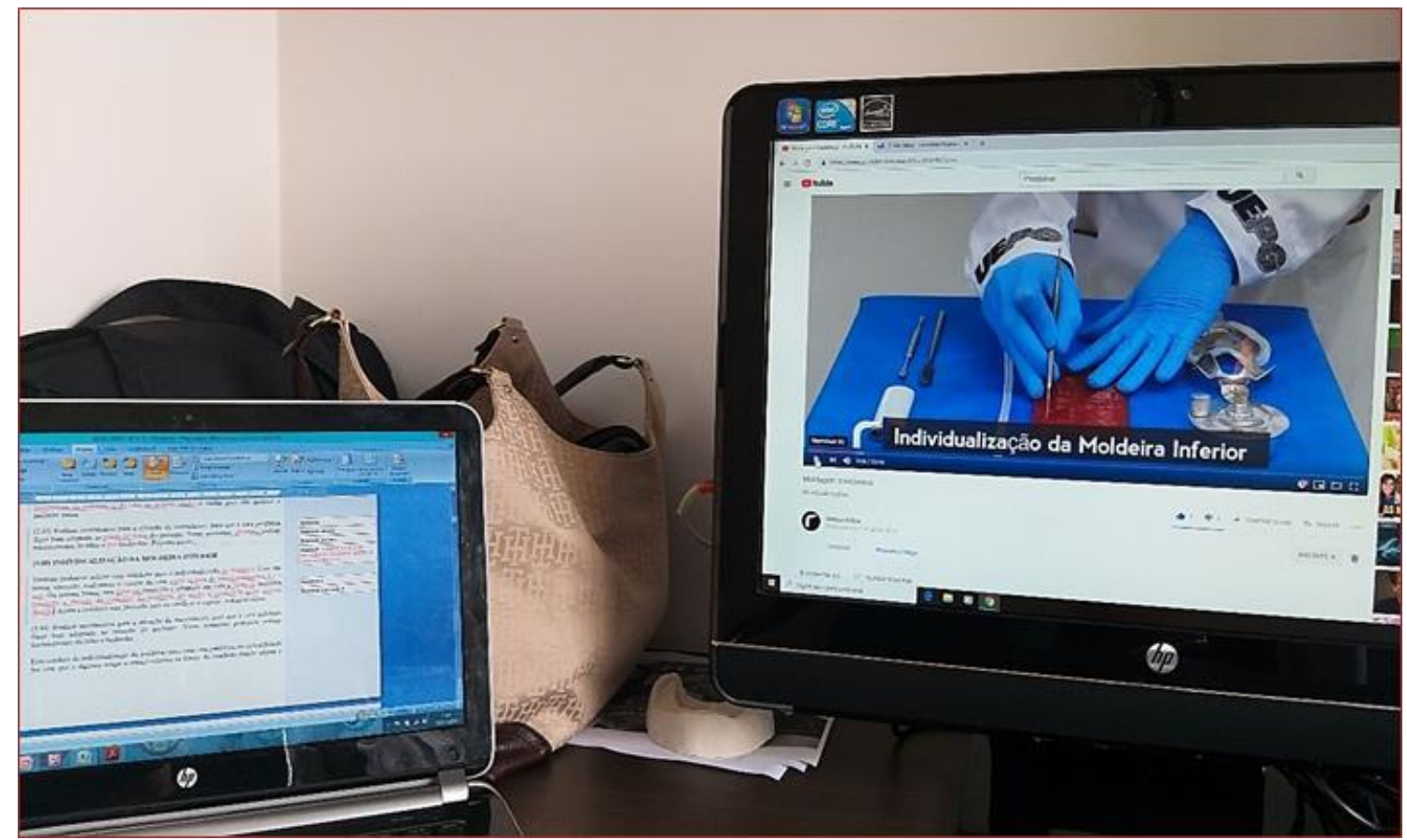

Foi necessário que os participantes reassistissem os vídeos inúmeras vezes após a edição para a redação dos textos.

Figura 5 - Gravação do áudio de alguns dos vídeos, realizada em estúdio com equipamento apropriado

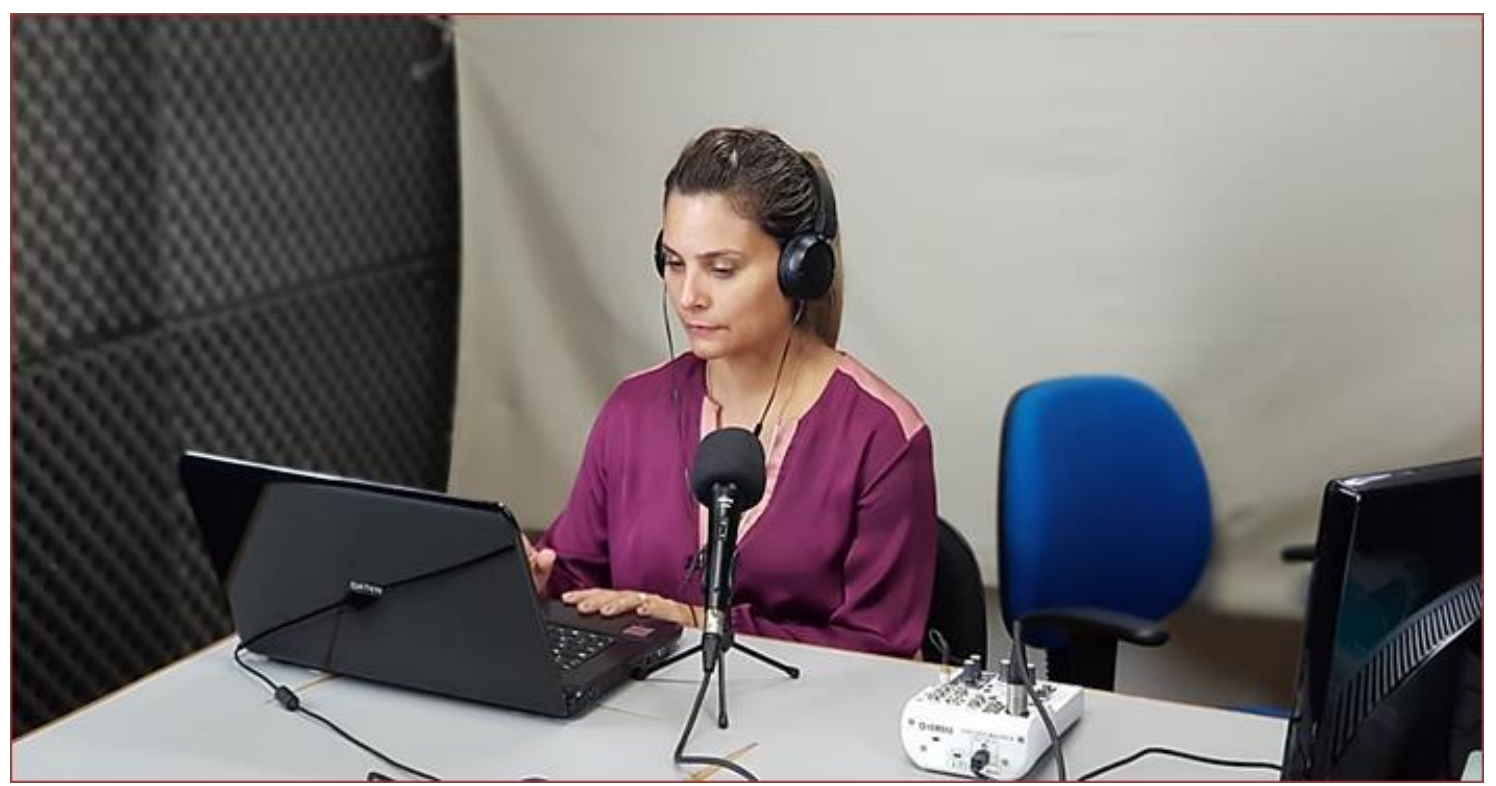

Gravação de áudio feita anteriormente à pandemia da COVID-19.

Após o término das gravações de imagens, os vídeos foram editados utilizando o software Final Cut Pro (Apple Inc.) (Figura 6), renderizados e disponibilizados publicamente no YouTube ${ }^{\circledR}$ no canal Remov Online (disponível em: https://www.youtube.com/channel/UCWZhUsaKjv7t6d87eAVt13A), criado especificamente para tal fim. 0 canal foi construído e recebeu um logotipo próprio, assim como um banner colocado na região superior da visualização do site (Figura 7). 
Figura 6 - Captura de tela do software Final Cut Pro, utilizado para a edição dos vídeos de Prótese Total

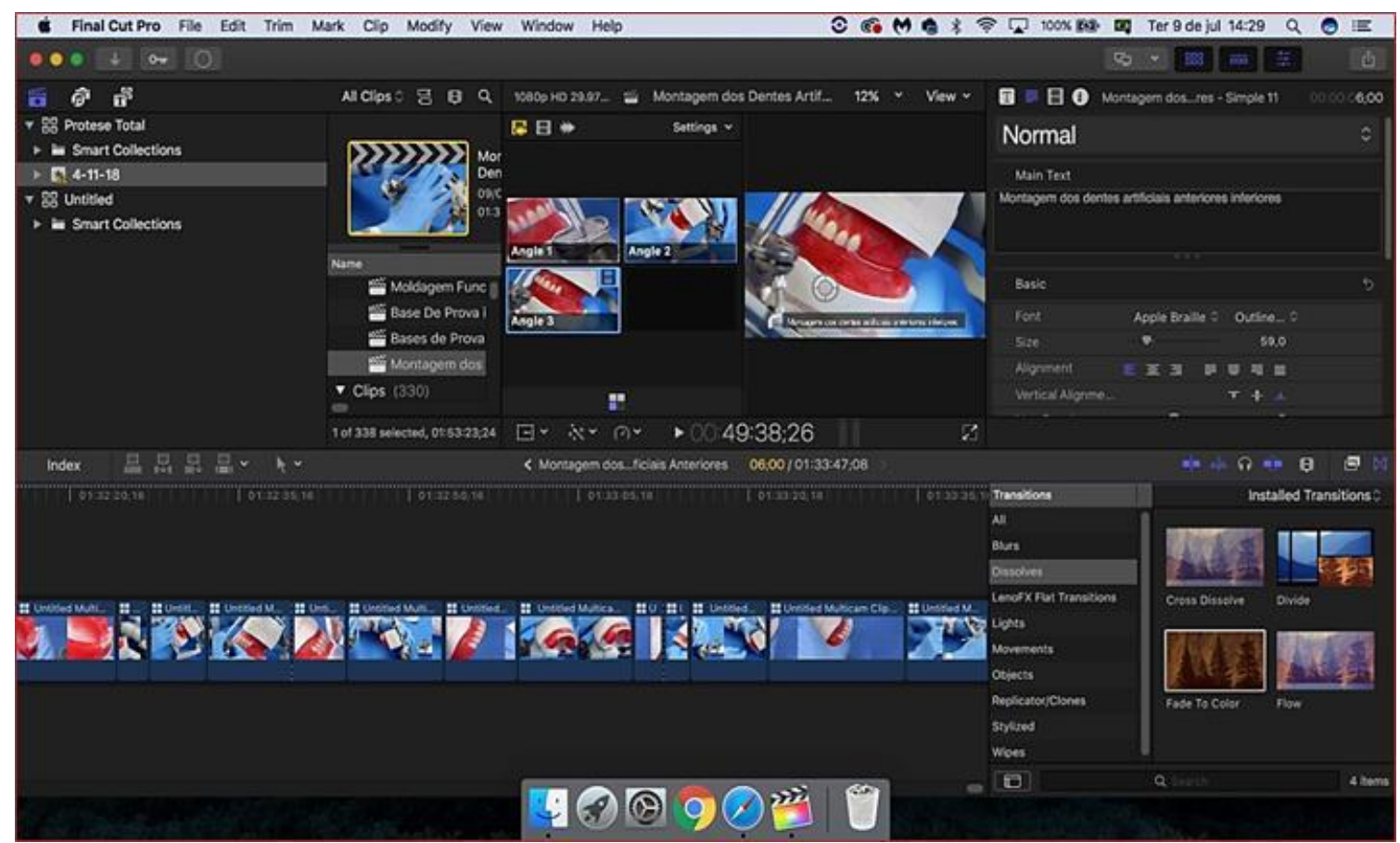

A figura apresenta parte do processo de edição do vídeo Montagem dos dentes artificiais para confecção de Prótese Total

Figura 7 - Página de acesso inicial do canal Remov Online no YouTube ${ }^{\circledR}$

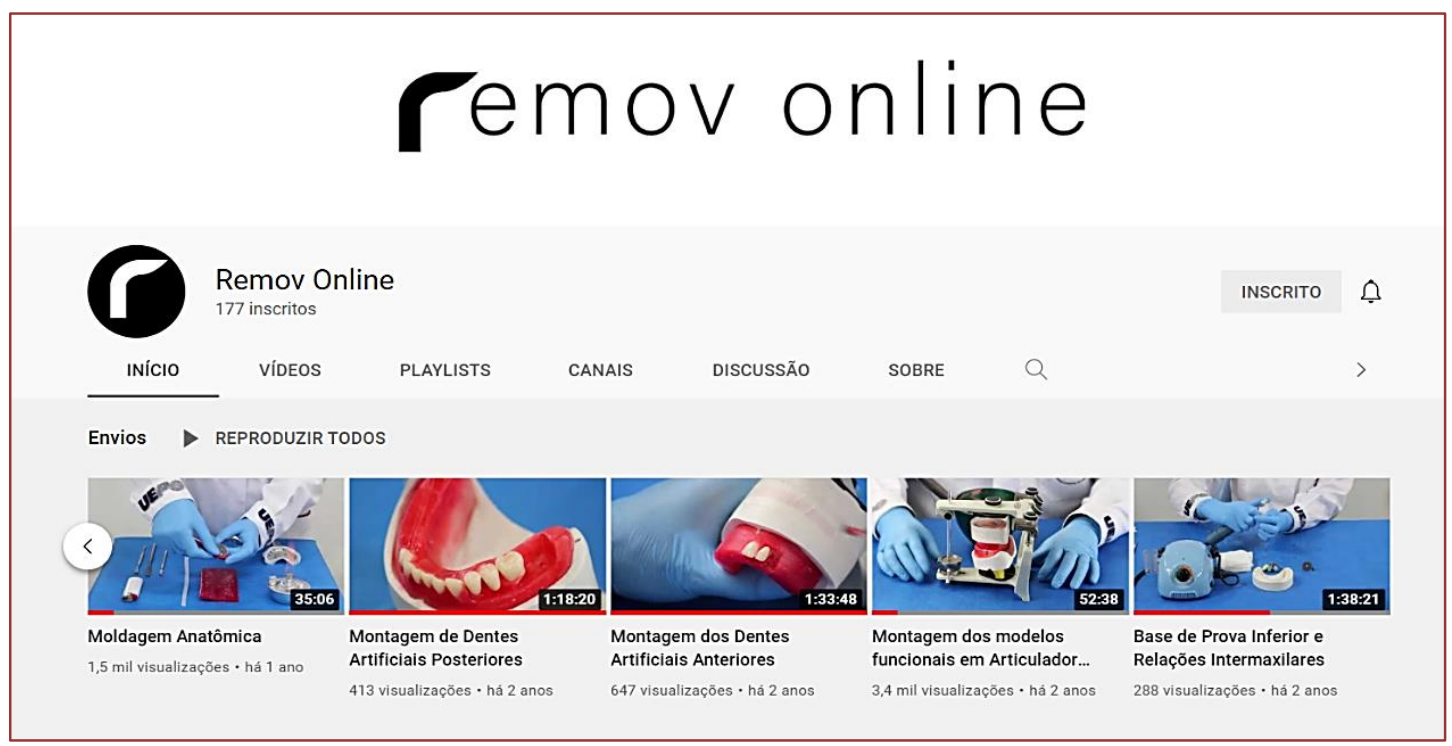

A figura mostra o logotipo e o banner do canal, número atual de inscritos e alguns vídeos de Prótese Total.

Após o upload dos vídeos produzidos, foram inseridos seus dados como título, descrição, contendo um resumo do material, informações adicionais e conteúdos complementares e miniaturas personalizadas que permitem a caracterização da capa do vídeo, destacando seu conteúdo para os inscritos no canal e objetivando aumentar sua visualização (Figura 8). Também foi feita a inserção de "Tags", que funcionam como palavras-chave. Todos os elementos visuais que compõem o canal, como logotipo, banner e miniaturas dos vídeos foram produzidos utilizando o software Adobe Photoshop CC (Adobe Inc., CA, EUA). 
Figura 8 - Captura de tela de um dos vídeos postados

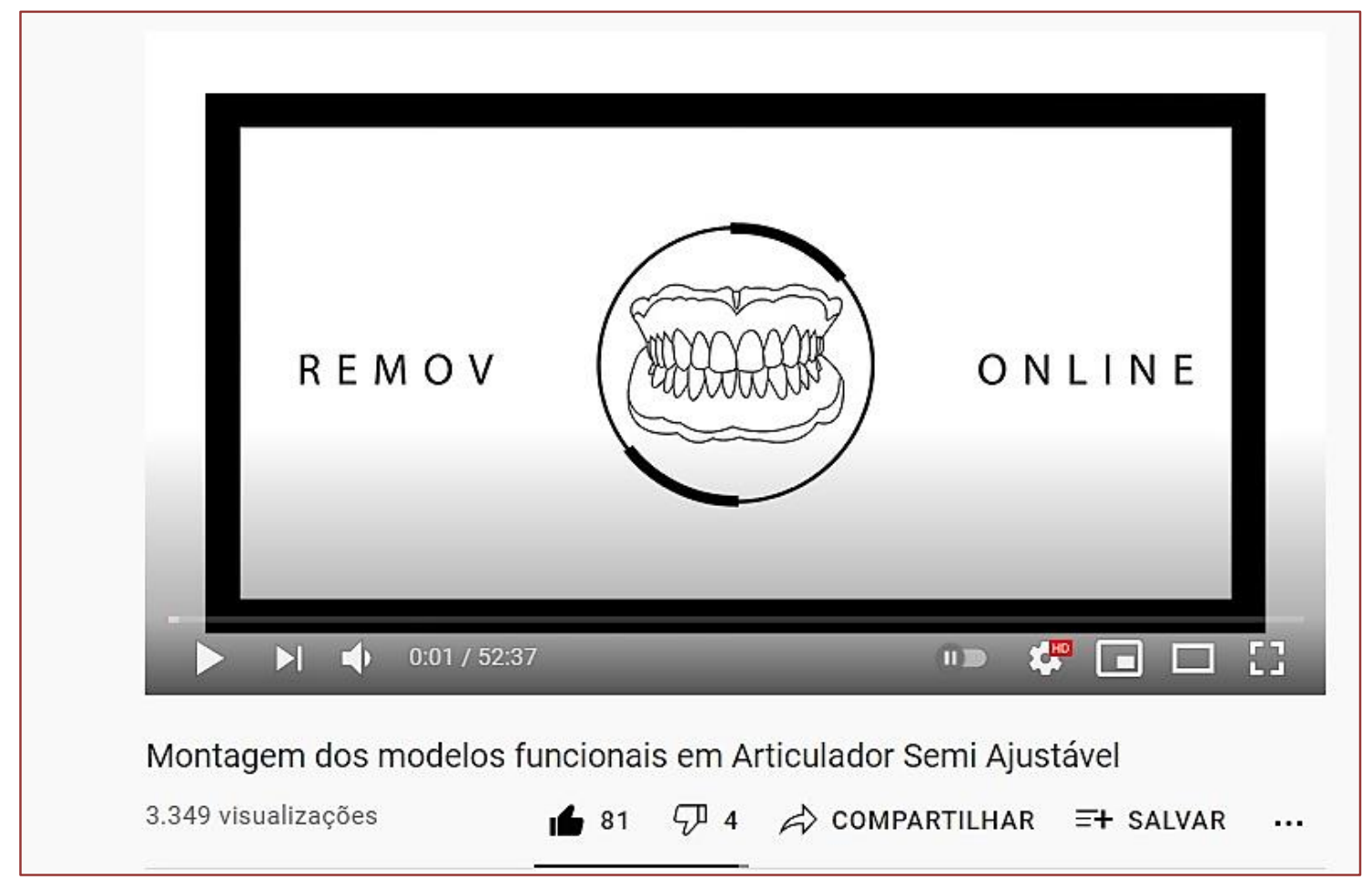

A figura apresenta o título e a duração do vídeo, número de visualizações e curtidas

Devido à dificuldade técnica e à demanda de muito tempo para a produção de todo o material, anteriormente à pandemia, a equipe havia produzido apenas os vídeos de Prótese Total e adicionado o áudio em apenas dois desses vídeos. Durante a pandemia, os vídeos com o conteúdo de Prótese Parcial Removível precisaram ser produzidos com urgência e em tempo reduzido. Todo o material capturado para a produção dos vídeos ou fotografias das demonstrações práticas de Prótese Parcial Removível foi obtido durante o ano de 2021, na residência de uma das professoras da equipe. Foi utilizado apenas um celular (Samsung Eletrônica da Amazônia Ltda., Manaus, AM, Brasil) acoplado em um iluminador led Ring light 10 polegadas e $25 \mathrm{~W}$ de potência com tripé de 1,80 m e suporte para smartphone. 0 iluminador apresentava controle de intensidade e de cor e base articulada, permitindo a iluminação em vários ângulos, além de possuir uma articulação para a movimentação do celular e obtenção de filmagens também em vários ângulos. 0 celular e o iluminador ficavam acoplados ao computador via fonte de alimentação USB (Figura 9). 
Figura 9 - Equipamentos utilizados para a gravação dos vídeos e obtenção das fotografias para o material didático de Prótese Parcial Removível

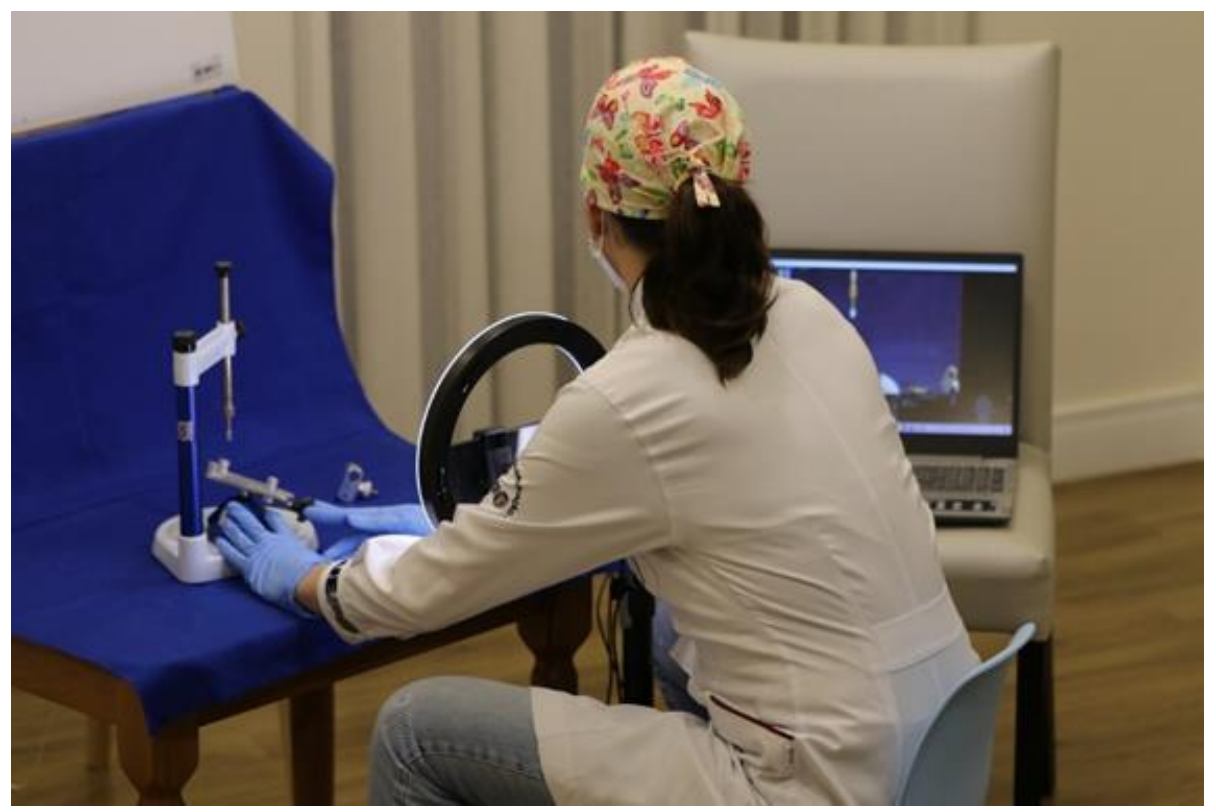

É possível observar um iluminador Ring Light com tripé e suporte para celular e a filmagem sendo executada e observada na tela do computador. Filmagem feita durante a pandemia da COVID-19

Devido à restrição de acesso à Universidade e ao isolamento social, a gravação dos vídeos precisou ser adaptada, e todo o processo foi conduzido e produzido por apenas uma das professoras da equipe. A professora também utilizou EPIs e realizou os procedimentos de confecção de Prótese Parcial Removível, simulados em manequim e em modelos de gesso para a disciplina pré-clínica, de acordo com a filosofia preconizada na Universidade.

As capturas de imagens foram feitas utilizando o aplicativo Iriun Webcam for Windows 2.6.6 (Iriun, Uptodown.com, Malaga, Espanha) e transferidas para o programa de streaming e gravação OBS Studio 27.0.1 (OBS Project, https://obsproject.com/pt-br) (Figura 10).

Figura 10 - Captura de tela do software OBS Studio, utilizado para a gravação dos vídeos de Prótese Parcial Removível

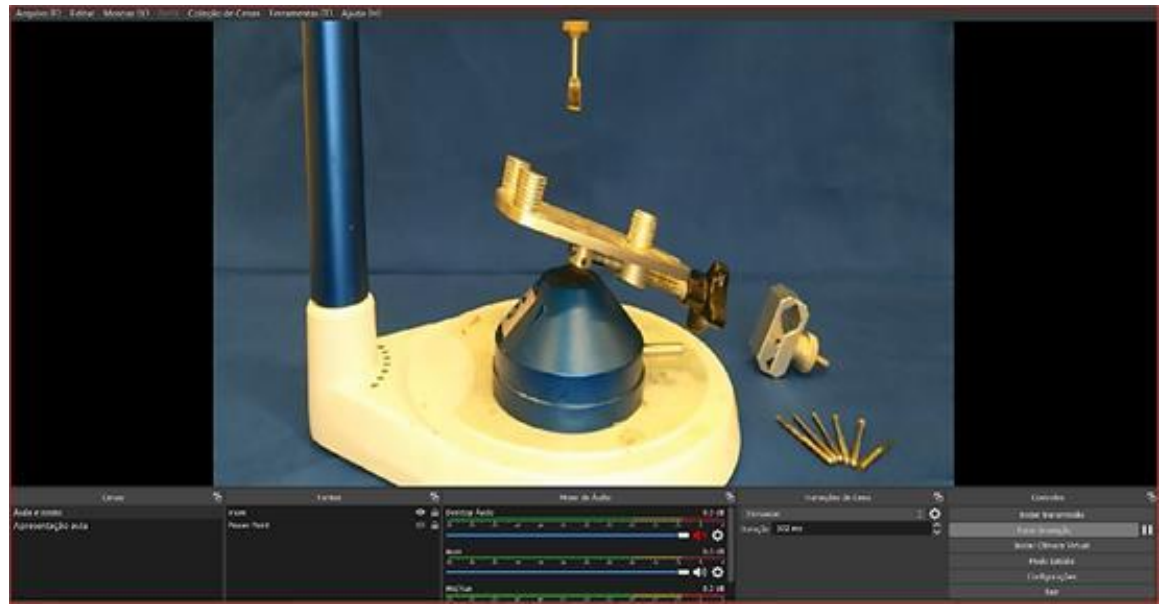

A figura apresenta parte da gravação do vídeo Análise em delineador para confecção de Prótese Parcial Removível 
Após o término das gravações de imagens, os vídeos foram editados utilizando o software Win Movie Maker (Microsoft Corp., Redmond, Washington, EUA) (Figura 11), renderizados e disponibilizados publicamente no YouTube ${ }^{\circledR}$ no canal Remov Online.

Figura 11 - Captura de tela do software Win Movie Maker, utilizado para a edição dos vídeos de Prótese Parcial Removível

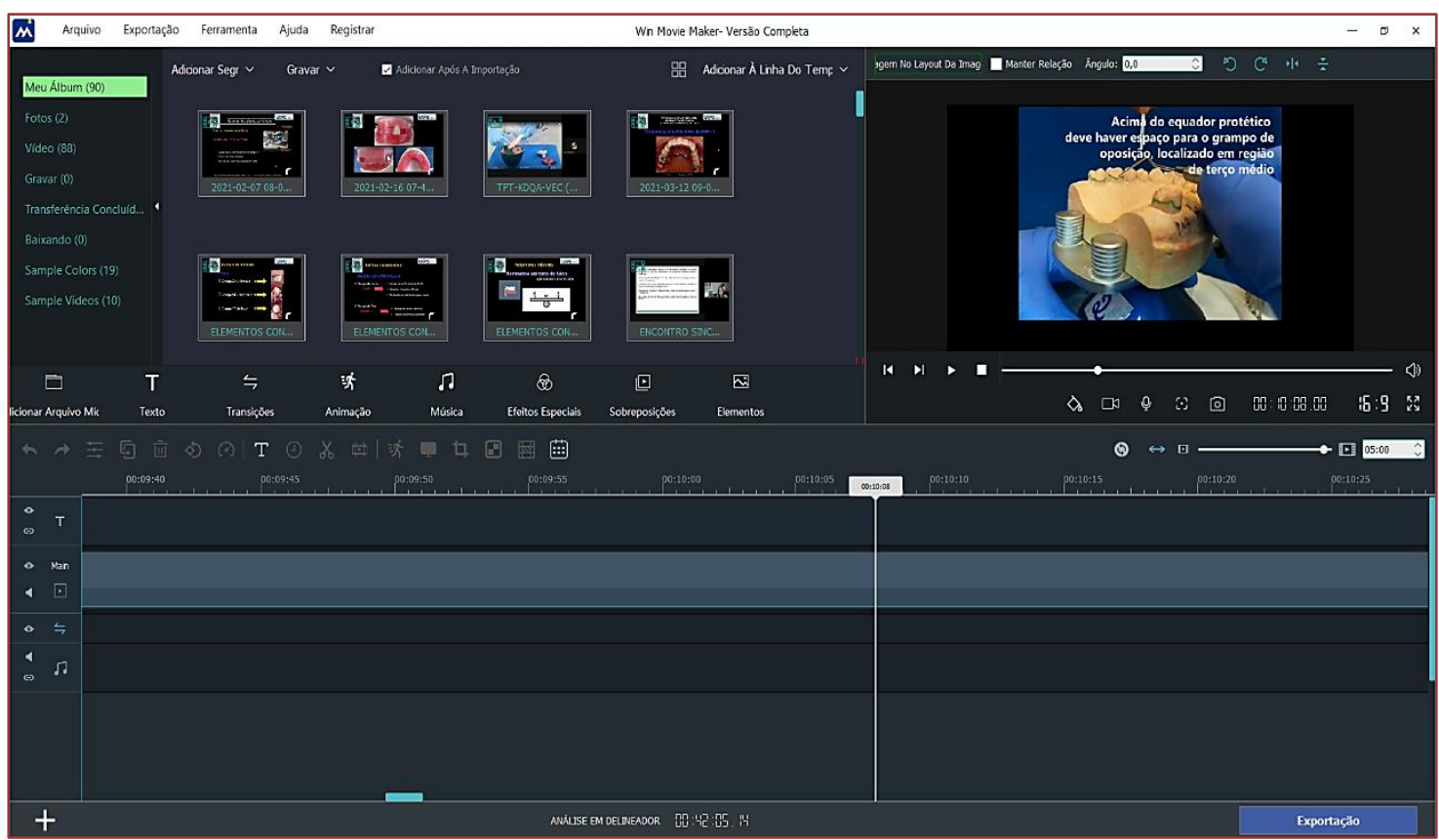

A figura apresenta parte da edição do vídeo Análise em delineador para confecção de Prótese Parcial Removível.

\section{RESULTADOS E DISCUSSÃO}

As gravações resultaram em aproximadamente 1,5 TB (terabytes) de arquivo bruto para ser editado, incluindo fotografias e vídeos.

Foram produzidos os seguintes vídeos didático-pedagógicos, que podem ser encontrados no canal Remov Online do YouTube ${ }^{\circledR}$ :

- Moldagem anatômica (com áudio) (https://youtu.be/qYwPtlETUmc);

- $\quad$ Área chapeável e Moldeira individual (com áudio) (https://youtu.be/NM12IkpUcx0);

- Moldagem funcional superior (https://youtu.be/B2N99-nbm-8);

- Moldagem funcional inferior (https://youtu.be/1tdgtFwXvLw);

- $\quad$ Base de prova superior (https://youtu.be/TiGDKY9_MXs);

- $\quad$ Base de prova inferior e Relações intermaxilares (https://youtu.be/9191BTyGy5o);

- Montagem dos modelos funcionais em Articulador semi-ajustável

(https://youtu.be/vPTdJezqsyc);

- Montagem dos dentes artificiais anteriores (https://youtu.be/7gCJcY--CD0);

- Montagem dos dentes artificiais posteriores (https://youtu.be/lvqT5AswLOQ);

- $\quad$ Preparo do manequim parcialmente desdentado (https://youtu.be/SxBbOkIvcBc);

- Moldagem de estudo em PPR (https://youtu.be/XECljZU50B4);

- Confecção de bases de registro e registros para montagem de modelos de estudo em ASA 
(https://youtu.be/lMiBrcg28BQ);

- Confecção de moldeira individual para PPR (https://youtu.be/0oLb7Uuk0-U);

- $\quad$ Análise em delineador dos modelos de estudo em PPR (https://youtu.be/7QZ9S29t5v0);

- Moldagem e delineamento do modelo mestre (https://youtu.be/LtFnWB3zGEs).

A partir do desenvolvimento do presente Projeto, o aprendizado dos acadêmicos e a execução dos procedimentos necessários para a confecção de próteses totais e próteses parciais removíveis durante as aulas práticas do Curso de Odontologia da UEPG vêm sendo otimizados. 0 material de demonstração prática de Prótese Total foi produzido em alta qualidade, utilizando-se de tomadas em diversas vistas e aproximações, possibilitando, dessa forma, maior compreensão do que está sendo realizado em comparação com as tradicionais demonstrações prévias às aulas práticas pré-clínicas.

Os alunos de graduação e pós-graduação envolvidos na elaboração do material puderam aperfeiçoar seu conhecimento em relação ao conteúdo abordado, que, por sua vez, resultou em enriquecimento de seus currículos e pontuação de produção técnica para o Programa de Pós-Graduação em Odontologia da UEPG.

Apesar de não ter sido a intenção inicial do Projeto, os vídeos acabaram por se tornar indispensáveis para o cumprimento da carga horária da disciplina durante o período em que as atividades universitárias se tornaram exclusivamente remotas devido à pandemia e também durante o retorno das atividades presenciais para evitar aglomerações no laboratório de ensino (PIRES \& FONTANELLA, 2020). Frente às circunstâncias em que estamos vivendo, professores do mundo todo precisaram se adaptar rapidamente e desenvolver novas maneiras de compartilhar seus conhecimentos com seus alunos.

Assim, devido à impossibilidade de os integrantes da equipe se reunirem para as gravações, todo o processo de produção, edição, renderização e postagem dos vídeos de Prótese Parcial Removível foi realizado por apenas uma professora em sua residência. 0 que foi extremamente trabalhoso e desafiador, tanto pelas diversas dificuldades devido à ausência dos demais membros da equipe e de todos os equipamentos necessários, como devido ao curto período de tempo em que eles precisaram ser produzidos e disponibilizados a fim de atender a demanda da disciplina. Ainda assim, tais vídeos permitiram que os alunos pudessem manter seus estudos mesmo nos períodos mais críticos da pandemia.

Embora existam diversas ferramentas tecnológicas que auxiliam no ensino virtual, algumas dificuldades também são enfrentadas (DHAWAN, 2020). De acordo com uma pesquisa realizada com mais de 39 mil estudantes chineses, a combinação de vídeos pré-gravados com aulas interativas ao vivo poderia reduzir o impacto negativo de conexões de internet instáveis e aumentar a participação e o engajamento dos alunos (SUN, TANG \& ZUO, 2020). Como mencionado anteriormente, um dos maiores benefícios de se disponibilizar o conteúdo virtualmente é a possibilidade de o aluno acessá-lo quando lhe for conveniente, contornando assim as eventuais falhas de conexão.

Um estudo realizado na Alemanha avaliou a efetividade do ensino combinado na disciplina de Prótese Dentária (REISSMANN et al., 2015). Além das aulas tradicionais, os alunos também tiveram acesso a módulos virtuais, com vídeos demonstrativos que eram disponibilizados online. Comparado aos anos anteriores, esse método de ensino apresentou uma melhora significativa no desempenho e satisfação dos acadêmicos com relação ao conteúdo ministrado. Ainda é cedo para conseguir mensurar o impacto que os vídeos tiveram e estão tendo no aprendizado dos alunos da disciplina na UEPG, porém, com base em experiências recentes, acredita-se que o conteúdo produzido vem otimizando o desenvolvimento das atividades práticas dos acadêmicos no Curso de Odontologia.

\section{CONCLUSÃO}

A equipe mostrou-se satisfeita com o produto final obtido, visto que se buscou produzir um material com o maior cuidado possível, atentando-se aos mínimos detalhes. Alguns desafios foram encontrados, como a disponibilidade de tempo de toda a equipe para as gravações, a nomeação e a organização do material bruto para facilitar a edição, além do tempo necessário para realizar a renderização e upload dos vídeos para plataforma do YouTube ${ }^{\circledR}$, momento que depende do processamento do computador utilizado e da velocidade da Internet.

O Projeto contribuiu para a formação dos alunos envolvidos, assim como contribuirá para toda a comunidade que tiver acesso ao seu conteúdo. A partir do know-how e da infra-estrutura adquiridos com a 
execução deste Projeto, espera-se produzir e encorajar a produção de outros vídeos didático-pedagógicos relacionados à área de Reabilitação Oral na UEPG.

\section{REFERÊNCIAS}

[1]. BRASIL. Constituição da República Federativa do Brasil. Brasília - DF. Outubro de 1988. Disponível em: http://www.planalto.gov.br/ccivil_03/constituicao/constituicao.htm. Acesso em: 19 set. 2021.

[2]. $\quad$ BRASIL. Lei de Diretrizes e Bases da Educação Nacional, LDB. 9394/1996. Brasília - DF. Dezembro de 1996. Disponível em: http://www.planalto.gov.br/ccivil_03/Leis/L9394.htm. Acesso em: 19 set. 2021.

[3]. BRASIL. Ministério da Educação. Conselho Nacional de Educação. Proposta de parecer sobre reorganização dos calendários escolares e realização de atividades pedagógicas não presenciais durante o período de pandemia da COVID-19. Brasília - DF. Março de 2020. 14p. Disponível em: http://portal.mec.gov.br/docman/marco-2020pdf/144511-texto-referencia-reorganizacao-dos-calendarios-escolares-pandemia-da-covid-19/file. Acesso em: 19 set. 2021.

[4]. DHAWAN, S. Online Learning: A Panacea in the Time of COVID-19 Crisis. J Educ Technol Syst. v. 49, n. 1, p. 522,2020

[5]. LECHNER, S. K. et al. Planning oral rehabilitation: case-based computer assisted learning in clinical dentistry. Br Dent J. v. 191, p. 152-156, 2001.

[6]. MARSON, I. C. V.; DOS SANTOS, A. V. Internet e prática pedagógica: possibilidades para a docência da língua inglesa. Revista e-curriculum. v. 5, n. 2, 2010.

[7]. PACKER, M. E. et al. A comparison between videotaped and live demonstrations for the teaching of removable partial denture procedures. Eur J Dent Educ. v. 5, p. 17-22, 2001.

[8]. PIRES, F. S.; FONTANELLA, V. Consenso Abeno: biossegurança no ensino odontológico pós-pandemia da COVID-19. Porto Alegre: ABENO, 2020. 86p. Disponível em: http://www.abeno.org.br/arquivos/downloads/retomada_de_praticas_seguras_no_ensino_odontologico.pdf. Acesso em: 03 jul. 2020.

[9]. REISSMANN, D. R. et al. A model of blended learning in a preclinical course in prosthetic dentistry. J Dent Educ. v. 79, n. 2, p. 157-165, 2015.

[10]. SHAH, N. et al. Effectiveness of an educational video in improving oral health knowledge in a hospital setting. Indian J Dent. v. 7, n. 2, p. 70-75, 2016.

[11]. SUN, L.; TANG, Y.; ZUO, W. Coronavirus pushes education online. Nat Mater. v. 19, p. 687, 2020. 


\section{Capítulo 7}

\section{Competências pedagógicas e saúde dos docentes em Educação à Distância}

\section{Veridiana de Vasconcelos Duarte}

Regiane da Silva Macuch

Arthur Gualberto Bacelar da Cruz Urpia

Resumo: 0 presente trabalho destina-se ao estudo das abordagens conceituais e seus fundamentos de ensino a distância e o desafio de relacionar a tecnologia com a metodologia, na perspectiva de transformar a informação recebida em conhecimento adquirido, apoiando-se nos pressupostos da qualidade de ensino em relação a prática pedagógica e saúde dos docentes. A análise do trabalho recai, em um primeiro momento, sobre conceitos relacionados ao surgimento e continuidade do ensino à distância. Em seguida, aborda os conhecimentos a respeito de ensino e aprendizagem de práticas pedagógicas e saúde, além de indicadores de aperfeiçoamento como referência para a melhoria na qualidade. Como resultado, tem-se uma análise sobre os processos de ensino em educação à distância e os requisitos necessários para a efetiva aprendizagem, suas viabilidades e recursos que proporcionam a melhoria ao ensino e o exercício dos docentes.

Palavras-Chave: Competências; Educação à Distância; Qualidade de Ensino e saúde. 


\section{INTRODUÇ̃̃O}

A crescente evolução tecnológica está determinando uma nova ordem econômica e social nos mais variados campos da ação humana. Na área da educação, o desenvolvimento científico e tecnológico vem criando nos educadores a necessidade de adotar modelos de ensino que atendam às profundas modificações que a sociedade do novo século passa a exigir, na qual a perspectiva de diversificar os espaços educacionais revela um aprendizado sem fronteiras.

0 ambiente educacional convencional vem encontrando dificuldades para responder adequadamente, tornando difícil para o setor educacional capacitar e atender à crescente demanda de pessoal qualificado solicitado pelo mercado.

Assim, a Educação a Distância (EAD) aparece como forte opção para solucionar este problema, empregando recursos com alto poder de difusão e possibilitando às pessoas estarem distribuídas geograficamente e temporalmente somando informações e transformando-as em conhecimento, segunda afirma CUNHA, (2019, p. 183).

[..] aprender, ensinar, criar, apreciar, produzir instrumentos, desenvolver hábitos, conviver, entre outros processos requerem sempre produção de sentidos. 0 campo da educação enquanto conjunto de práticas sociais mediante as quais um grupo assegura que seus membros adquiram a experiência e o conhecimento acumulado e culturalmente organizado [...].

A própria globalização da economia e da cultura fez com que o homem se tornasse um ser globalizado, principalmente com a evolução das tecnologias, justificando a intensificação da busca pela EAD. Segundo Kotler (2017), criar valor e satisfação para o cliente é o ponto central do pensamento. Contudo, faz-se necessário que atributos de qualidade e outros requisitos estejam presentes na perspectiva de ensino e do exercício pelos docentes e que estejam aptos em conhecimentos, bem como condições de saúde para que o ensino realmente possa ser viabilizado. Segundo Lévy (1999), a próxima transformação virá com a internet semântica, que está sendo desenvolvida e será uma linguagem comum capaz de representar os vários aspectos da vida. A proposta da internet semântica ajudará a selecionar conteúdos e melhorará a linguagem entre as pessoas que utilizam a tecnologia.

Tendo isso em vista, este trabalho faz um estudo referente às competências dos docentes a utilizarem os diversos recursos do ensino em educação à distância, bem como terem condições de saúde para exercerem. 0 ensino à distância embora seja um tema abordado em estudos e pesquisas, sua maior problemática encontra-se exatamente no excesso de pesquisas e relatórios com esse enfoque, com resultados que, a rigor, dificultam a compreensão de diferenças significativas da qualidade na educação não presencial e presencial.

A estrutura do presente trabalho encontra-se fundada em dois temas: no primeiro tem-se um breve histórico de EAD sua conceituação e suas concepções por meio de modelos pedagógicos e práticas; em num segundo tem-se a metodologias de ensino; já, em um terceiro momento, discute-se sobre a qualidade e saúde. E, por fim, são apresentadas as considerações finais deste estudo.

\section{MATERIAIS E MÉTODOS}

Para cada objetivo indicado foi definido uma estrutura metodológica, sendo que todos serão desenvolvidos a partir de um delineamento transversal descritivo. Foi desenvolvido um estudo sobre a EAD, a qual tem sua origem em remotos tempos, onde o homem precisava obter informações sem poder estar em locais pré-definidos. Transportando para a atualidade, a EAD se comporta como principal agente de transformação.

No sentido fundamental da expressão, segundo Chaves (1999), a EAD é algo muito antigo, nesse sentido fundamental, como vimos, EAD é o ensino que ocorre quando o ensinante e o aprendente estão separados, ou seja, no tempo ou no espaço. Obviamente, para que possa haver EAD, mesmo nesse sentido fundamental, é necessário que ocorra a intervenção de alguma tecnologia.

Graças aos suportes tecnológicos de hardware e software atuais, tornou-se possível a realização de aulas virtuais bem mais dinâmicas. 0 acesso à Internet e a disseminação da informação está possibilitando mudar a forma de produzir, conteúdo e consequentemente aprendizado. As fontes de pesquisa abertas aos alunos pela Internet, as bibliotecas virtuais em substituição às publicações impressas e os cursos à 
distância vêm crescendo.

O ensino e a aprendizagem são processos subjetivos, que acontecem diferentemente para cada pessoa. Tanto o ensino como a aprendizagem acontecem onde quer que esteja o indivíduo, que está se educando ou aprendendo. Nesse sentido, o pensamento parece convergir, quando explica (Luckesi apud Bolzan, 1989, p.23).

[..] a educação, nas suas mais diversas modalidades, não tem condições de sanear nossos múltiplos problemas nem satisfazer nossas mais variadas necessidades. Ela não salva a sociedade, porém ao lado de outras instâncias sociais, ela tem um papel fundamental no processo de distanciamento da incultura, da a criticidade e na construção de um processo civilizatório mais digno do que esse que vivemos [...].

Segundo alguns fundamentos, uma característica básica da educação a distância é o estabelecimento de uma dupla via, na medida em que o professor e o aluno não se encontram juntos fisicamente. A esse respeito Bolzan (1998), considera:

[..] A educação a distância é uma forma sistematicamente organizada de autoestudo onde o aluno se instrui a partir do material de estudo que lhe é apresentado, e onde o acompanhamento e a supervisão do sucesso são levados a cabo por um grupo de professores [...] (DOHMEM apud BOLZAN, 1998, p. 123).

Segundo Chaves (1999), ensinar a distância, porém é perfeitamente possível e, hoje ocorre o tempo todo, por exemplo, quando aprendemos por meio de um livro que foi escrito para nos ensinar alguma coisa ou assistimos a um filme, programas de televisão, um vídeo.

A expressão ensino a distância faz perfeito sentido neste contexto, porque quem está ensinando: o ensinante está espacialmente distante, e também distante no tempo de quem está aprendendo, no caso o aprendente.

Keegan apud Bolzan (1998), enumera os elementos fundamentais nesses conceitos abordados sobre ensino a distância.

[..] separação física entre professor e aluno, que o distingue do presencial; Influência da organização educacional (planejamento, sistematização, plano, projeto, organização dirigida, etc.) que a diferencia da educação individual; utilização de meios técnicos de comunicação, usualmente impressos, para unir o professor ao aluno e transmitir os conteúdos educativos; previsão de uma comunicação- diálogo, e da possibilidade de iniciativas de dupla via; possibilidade de encontros ocasionais com propósitos didáticos e de socialização; e participação de uma forma industrializada de educação [...] (KEEGAN apud BOLZAN, 1998, p. 52).

Essas variáveis, que distinguem o ensino a distância do ensino presencial, têm fortalecido principalmente a questão de uma comunicação-diálogo, onde no ensino presencial parece existir com muita ênfase.

No ensino a distância, as pessoas manifestam-se mais, sem medo de errar e sem medo de estarem se expondo aos demais colegas, e isto determina concretamente a possibilidade de atuação do ensino a distância. Também se deve salientar que a informação na educação a distância pode ser organizada de maneira crítica e construtiva, na medida em que a informação seja transformada em conhecimento, construindo e fortalecendo uma mentalidade crítica e criativa no público-alvo, como também possibilitar aos profissionais os conhecimentos sobre os avanços nas suas áreas específicas. Os profissionais docentes devem procurar construir competências atrelando as tecnologias, no entanto, nem sempre é fácil, e pode corresponder a exaustão e comprometer a saúde.

A educação a distância proporciona não só a capacitação e atualização de professores e funcionários de empresas, como também de grupos não governamentais, desde que bem dinamizada em relação ao período de exercício e atuação. 
Em relação ao serviço público, percebe-se que a incorporação do sistema tecnológico é cada vez maior, para atender a grande demanda, por melhores e mais rápidos serviços de qualidade, a EAD se insere nesse novo cenário tecnológico, pois o uso apropriado da tecnologia pode diminuir custos.

Driscool (1998) mostrou que alguns estudos sobre alunos utilizando computadores, em relação a tecnologia educacional aumentaram sua produção, melhorando a atitude e a autoimagem dos alunos e propiciando relacionamentos estudante-professor de melhor qualidade.

A tecnologia encoraja o pensamento criativo, promove a capacidade de empreendimento e desperta a curiosidade. Modelos pedagógicos e práticas sustentadas em EAD serão apresentados na sequência, possibilitando investigar a concepção de educação que se quer, a fim de que o ensino a distância possa desempenhar papel fundamental na sociedade.

\subsection{IDENTIFICAÇÃO E CARACTERÍSTICAS DO PROBLEMA}

Com a propagação da tecnologia é perceptível à necessidade de estudos com o intuito de compreender como a EAD pode de alguma forma não comprometer a saúde dos docentes e assessorar na promoção da saúde. Com esse intuito este trabalho foi desenvolvido a fim de responder a alguns questionamentos.

0 ensino a distância pressupõe um sistema de transmissão e estratégias pedagógicas adequadas às diferentes tecnologias utilizadas. A estratégia didática do ensino a distância, de acordo com Khan (1997), significa a escolha dos métodos e meios instrucionais estruturados para produzir um aprendizado efetivo. Isto inclui não apenas o conteúdo do curso, mas também decisões sobre o suporte ao aluno, acesso e escolha dos meios, bem como o docente esteja em condições de atuar. 0 modo como o professor/tutor e o aluno se comunica e interage depende do esquema de aprendizado que é usado.

0 processo de aprendizado no ensino a distância depende de pelo menos três fatores: o modelo de aprendizagem, a infraestrutura tecnológica e a infraestrutura da sala de aula. Dentre os modelos de aprendizagem na educação, o mais tradicional é o chamado de compartamentalista ou objetivista. Nesta forma de ensino, baseada em uma aprendizagem reprodutiva, o aluno é entendido como um sujeito passivo, que recebe uma série de informações prontas, trabalhando muito pouco sobre elas.

O ensino, segundo essa concepção, é encarado apenas como transmissão de conhecimentos. Quanto à educação, que sempre pretendeu atender a todos; o ensino a distância parece ser uma excelente alternativa, pois tem a capacidade de atender um grande número de pessoas que estão geograficamente dispersas e atende aos anseios do sistema educacional convencional, pois é possível desenvolver no ensino a distância um nível de consciência capaz de dar possibilidades de refletir e transformar a sociedade.

A educação a distância proporciona não só a capacitação e atualização de professores, alunos, funcionários de empresas, como também de grupos não governamentais com cursos abordados sob a ótica da saúde, ecologia, entre outros, para organização social. Já no modelo cooperativo ou colaboracionista, o aprendizado acontece na interação do indivíduo com os objetos.

É pela contribuição de diferentes entendimentos de uma mesma matéria que se chega a um conhecimento compartilhado. $\mathrm{O}$ professor age como um facilitador do compartilhamento em vez de controlar a entrega do conhecimento ao grupo e isto também pode ser estimulante para saúde do trabalhador docente.

A partir da década de 90, um novo modelo pedagógico é apresentado através do empoderamento, onde a experiência do conhecimento passa ser interativa e também o empoderamento na saúde, em que se procura ter mais cuidados com a saúde. A avaliação é sinônimo de capacitação e o avaliador agora passa a ser o colaborador, o facilitador. Trata-se do fortalecimento das pessoas, por meio de suas habilidades e contribuições significativas ao processo, sendo capazes de inovar sempre para a mudança, por meio do novo ou da novidade.

A forte contribuição do EAD para a mudança de paradigma educacional baseia-se na constatação de que a internet exige uma maior assertividade por parte do aluno, que deve conduzir o seu aprendizado. No sistema presencial é notória a passividade do aluno em relação à condução do processo ensinoaprendizagem. 


\subsection{PRÁTICAS PEDAGÓGICAS E SAÚDE}

As mudanças visíveis que estão ocorrendo na educação afetam diretamente o posicionamento do docente, mas também dos alunos que precisam aprender a aprender novamente. Muitos ainda esperam que o docente transmita o conteúdo mastigado, sem ter participação na construção do conhecimento.

Segundo Mccann (1995) antecipou sobre os professores fazerem aulas de comunicação, o ideal seria antecipar aulas de motivação pessoal para alunos também. 0 extraordinário é que o mestre Mccann da comunicação tenha tido uma previsão tão lúcida do fenômeno da escolarização do futuro, sem que seja, propriamente, um educador. Acontece, porém, que só agora os educadores estão tomando consciência de que a educação é um processo de comunicação e as melhores possibilidades da didática prospectiva estão na teoria da informação.

As faculdades de comunicação podem vir a ser, no futuro, as verdadeiras escolas de formação do docente, se é que a função de docente irá sobreviver às mutações pedagógicas que estão em vias de ocorrer, pelo menos nos países de civilização pós-industrial.

Segundo Chaves (1999), há uma conexão conceitual entre educação e aprendizagem: não há educação sem que ocorra aprendizagem ou, invertendo, se não houver aprendizagem, não haverá educação. A aprendizagem, por seu lado pode resultar de um processo de fora para dentro, como o ensino ou de um processo gerado de dentro para fora, autoaprendizagem. Tanto o ensino como a aprendizagem, são conceitos moralmente neutros. Pode-se ensinar e aprender tanto coisas valiosas como coisas sem valor ou mesmo nocivas.

A educação, porém, não é um conceito moralmente neutro. Educar alguém ou a si próprio é, por definição, fazer algo que é considerado moralmente correto e valioso. Outros conceitos podem ser usados em processos de certo modo parecidos com a educação, mas que não são moralmente aprovados, por exemplo, doutrinação.

A aprendizagem é um processo que ocorre dentro do indivíduo. Mesmo quando a aprendizagem é decorrente de um processo bem-sucedido de ensino, ela ocorre internamente, e o mesmo ensino que pode resultar em aprendizagem em algumas pessoas pode ser totalmente ineficaz em relação a outras, principalmente quando se encontra com a saúde abalada, o que pode ocorrer com o docente, se encontrar em situação fisicamente e mentalmente comprometida ao exercício da docência, Pimenta (2005).

\section{RESULTADOS E DISCUSSÕES NA QUALIDADE EM EAD E DOCENTES}

A Educação a Distância vem crescendo rapidamente incentivados pelas possibilidades decorrentes das novas Tecnologias da Informação e das Comunicações (TIC), cada vez mais cidadãos e instituições veem nessa forma de educação um meio de democratizar o acesso ao conhecimento e de expandir oportunidades de aprendizagem ao longo da vida GATTI (2005).

Assim, para efeito há indicadores, a qual considera-se que a diferença básica entre educação presencial e a distância está no fato de que, nesta, o aluno tem acesso ao conhecimento e desenvolve hábitos, habilidades e atitudes relativos ao estudo, à profissão e à sua própria vida, no tempo e local que lhe são adequados, não com a ajuda em tempo integral da aula de um professor, mas com a mediação de professores (orientadores, tutores e mediadores), atuando ora a distância, ora em presença e com o apoio de materiais didáticos sistematicamente organizados, apresentados em diferentes suportes de informação, utilizados isoladamente ou combinados, e veiculados através dos diversos meios de comunicação (conforme o Decreto no 2.494, de 10 de fevereiro de 1998, que regulamenta o artigo 80 da Lei de Diretrizes e Bases da Educação Nacional).

O desafio de educar e educar-se a distância é grande, por isso o Ministério da Educação estabelece indicadores de qualidade para a autorização de cursos de graduação à distância. Seu objetivo é orientar alunos, professores, técnicos e gestores de instituições de ensino superior que podem usufruir dessa forma de educação e empenhar-se por maior qualidade em seus processos e produtos.

A base principal das práticas de qualidade nos projetos e processos de educação superior é garantir continuamente melhorias na criação, aperfeiçoamento, divulgação de conhecimentos culturais, científicos, tecnológicos e profissionais que contribuam para superar os problemas regionais, nacionais e internacionais e para o desenvolvimento sustentável dos seres humanos, sem exclusões, nas comunidades e ambientes em que vivem. 
Espera-se que essa base de qualidade se apresente também em cursos a distância para o que, os indicadores sugeridos a seguir - dentre outros - possam colaborar. Os indicadores aqui sugeridos não têm força de lei, mas servirão de apoio e orientação.

O princípio-mestre é o de que não se trata apenas de tecnologia ou de informação: o fundamento da educação da pessoa para a vida e o mundo do trabalho. São dez os itens básicos que devem merecer a atenção das instituições que preparam seus programas a distância:

1. Integração com políticas, diretrizes e padrões de qualidade definidos para o ensino superior como um todo e para o curso específico;

2. Desenho do projeto: a identidade da educação à distância;

3. Equipe profissional multidisciplinar;

4. Comunicação/interatividade entre professor e aluno;

5. Qualidade dos recursos educacionais;

6. Infraestrutura de apoio;

7. Avaliação de qualidade contínua e abrangente;

8. Convênios e parcerias;

9. Edital e informações sobre o curso a distância;

10. Custos de implementação e manutenção à distância.

Além desses aspectos, a instituição proponente poderá acrescentar outros elementos mais específicos e que atendam a particularidades de sua organização e necessidades socioculturais de sua clientela, cidade e região. E um outro fator de fundamental importância abrange a questão da metodologia, tornando-se índice importante em termos de qualidade em ensino a EAD. Certamente não se tem uma metodologia única para EAD, mas todas deverão dar conta dos amplos aspectos envolvidos nesta modalidade de trabalho educativo: produção de texto, produção e utilização de imagens, desenho do ambiente virtual, comunicação e interação com alunos, entre alunos e professores.

No desenvolvimento de metodologias, então, temos que considerar todos os aspectos e ao mesmo tempo, não se pode pensar no ambiente sem pensar no tipo de texto, na dinâmica, no estudo de caso que será veiculado, e não podemos pensar no tipo de texto ou outros recursos metodológicos sem definir a maneira como utilizar algo que depende da estruturação de conhecimentos sobre quais maneiras mostram-se mais fecundas quando se ensina e estuda online - do ponto de vista do professor/mediador e do aluno.

Tudo isso deverá estar, ainda, mostrando-se coerente cada ponto com a concepção de educação assumida pela pessoa que propõe um curso sob a pena de integrarmos soluções e estratégias tecnológicas e pedagógicas cujos princípios norteadores sejam contraditórios.

Isso leva-nos a pensar sobre a validade das propostas de desenvolvimento de ferramentas e estratégias para trabalhar em ambiente virtual desenvolvidas por áreas especializadas e pensar na metodologia como algo que só pode ser estruturado considerando o todo, tem-se que cobrar e utilizar de cada nova ferramenta e estratégia uma coerência como um todo.

\section{CONSIDERAÇõES FINAIS}

A sociedade da informatização é uma realidade que nos leva a uma reflexão do papel do homem dentro do contexto repleto de máquinas, tecnologia e rapidez no processamento das informações. A inserção da informática na escola quer como instrumento de auxilio as tarefas pedagógicas "informática na educação", quer no ensino das linguagens de programação e uso de aplicativos "educação de informática", vem se fundamentando no meio educacional, tornando-se um processo irreversível. Isto exige da escola e principalmente o docente, que se tenha uma concepção clara quanto ao uso dessa ferramenta com o objetivo de auxiliar e não prejudicar a saúde e o ensino.

0 docente de qualquer disciplina deve continuar sendo um mediador na sua área e possuir uma cultura geral, que lhe permita ser usuário e planejar suas atividades ativas, como colher materiais e trocar experiências, proporcionando aos seus alunos uma nova dimensão da relação com o mundo e sempre 
cuidando e preservando sua saúde para que ao promovê-la obtenha melhores resultados em relação a qualidade de vida profissional.

No decorrer de desenvolvimento deste estudo buscou-se dar ênfase que o uso dessa ferramenta de apoio não pode ser visto como um simples objeto de trabalho e sim como oportunidade de contribuir dentro da proposta de inovar.

Tecnologia, essa, que deve ser utilizada como meio para alcançar fins, ou seja, o docente deve preparar-se para as transformações sociais e culturais que advirão do seu uso. E a EAD é um método que proporciona acessibilidade a milhares de estudantes e proporciona a propagação do ensino.

É preciso orientar, acompanhar, estimular a pesquisa e debater os resultados, dentro do desafio que essa forma de ensino é uma poderosa ferramenta de aproximação entre docentes e alunos e não o contrário. Aproxima o ensino de quem está geograficamente distante. Na informática e na educação, nada é estático e definitivo, a tecnologia com fins educacionais é quase tão infinito quanto suas ramificações e só encontra seu limite na imaginação de docentes e alunos.

Vale salientar que a EAD não decreta a ruína da educação presencial. Ela apenas representa mais um meio pelo qual se dispõe para promover a educação. A tecnologia deve-se admitir que é um meio que vem mudando lógicas de pensamento e formas de vida, proporcionado aproximação de fronteiras virtuais.

Para finalizar este estudo, trata-se de temas relacionados a EAD e a qualidade de ensino e o exercício docente em relação a saúde, através destas ferramentas tecnológicas. Posteriormente, no decorrer poderá ocorrer uma continuação para estudos futuros, a partir da realidade ocupacional de docentes na atuação que engloba a EAD.

\section{REFERÊNCIAS}

[1]. BOLZAN, R. F. F. A. O conhecimento tecnológico e o paradigma educacional.

[2]. Santa Catarina: UFSC, 1998. (Dissertação, Mestrado). Disponível em: http://www.eps.ufsc.br/disserta98/regina/index.htm. Acesso em: fev. 2019.

[3]. CUNHA, Renata Cristina O. Educação e Promoção da Saúde. Editora Santos. 2019. p. 183.

[4]. CHAVES, Eduardo. Conceitos de Educação à Distância. 1999. Disponível em: http://www.edumed.org.br. Acesso em: maio. 2019.

[5]. DRISCOOL, Margaret. Web based training: using technology to design adult learning experiences. Jossey: Bass Pfeiffer, 1998.

[6]. GATTI, Bernadete. Critérios de qualidade. In: ALMEIDA, Maria Elizabeth Bianconcini de; MORAN, José Manuel (Org.). Integração das tecnologias na educação: salto para o futuro. Brasília: Seed, 2005. p. 142-145. Disponível em: http://portal.mec.gov.br/seed/arquivos/pdf/4sf.pdf. Acesso em: 01 jun. 2019.

[7]. KHAN, Badrel H. Web Based Instruction. Educacional Technology Publications, 1997.

[8]. KOTLER, Philip. Hermawan Kartajaya, Iwan Setiawan. Markteng 4.0 do Tradicional ao Digital. Sextante. 2017. p. 98.

[9]. LÉVY, Pierre. As tecnologias da inteligência - o futuro do pensamento na era do conhecimento. Trad. Carlos Irineu da Costa; revisão Ivana Bentes. Rio de Janeiro p. 34. 1999.

[10]. MCCANN, John. Education on Demand. Fuqua School of Business, 1995. Disponível em: http://people.duke.edu/ mccann/resume.htm. Acesso em: mar. 2019.

[11]. PIMENTA, S. G. Docência no ensino superior. 2. ed. São Paulo: Cortez, 2005. 


\section{Capítulo 8}

Promover saúde educando hábitos em Escola de Ensino Fundamental no Sul da Bahia

\section{Cecilia Rodrigues da Silva Neta}

Sandro Menezes de Oliveira

Patrycia Batista Nery Silva

João Luis Almeida da Silva

Aretusa de Oliveira Martins Bitencourt

Resumo: Trata-se de um relato de experiência com o objetivo de descrever o desenvolvimento de ações educativas em promoção à saúde no território vivo compartilhado por uma Escola Municipal de Ensino Fundamental e uma Unidade Básica de Saúde em um município do sul da Bahia. Os resultados foram materializados pelos alunos em cordéis e histórias em quadrinhos, consequência do envolvimento dos mesmos com processo de ensino-aprendizagem por meio de rodas de conversa e confecção de uma horta no espaço escolar. Como modelo estratégico, utilizou-se a pesquisa-intervenção que fomenta à uma construção de espaços para a problematização coletiva; com o intuito de superar o cenário da baixa qualidade alimentar das crianças e adolescentes nos espaços escolares.

Palavras-chave: Programa Saúde na Escola, saúde escolar, alimentação saudável, promoção da saúde 


\section{INTRODUÇÃO}

Historicamente, o ponto inicial da política em saúde escolar foi na Alemanha. Nos primórdios do século XIX, o Programa Frank atuava nos espaços escolares baseados em paradigmas intervencionistas centrados na polícia médica. Esta abordagem higienista trabalhava com conteúdos que versavam de vestimentas à demografia, ou ainda sobre saneamento ou doenças infectocontagiosas. Foi do território germânico que à abordagem aos infantes no período escolar se espalhou para toda a Europa. (FIGUEREDO et al., 2010; CARVALHO, 2015)

Já em 1870 a atenção aos espaços escolares chega na América pelas portas Estadunidenses. Ainda de modo fiscalizador e higienista, era direcionada à crianças e jovens afro-americanos e, incluía atividades físicas e ações vivenciadas ao longo do dia. Atualmente, a estratégia americana está voltada ao enfrentamento da obesidade e na promoção de saúde. (FIGUEREDO et al., 2010; ROBINSON et al., 2014)

No Brasil, a questão higienista ganha proporção no início do século XX. Isso porque, as lavouras de café em expansão eram alimentadas por grandes levas de imigrantes e junto esse contexto, o país vivia uma pesada crítica a saúde pública vigente. Sanitariamente assolavam à varíola, hanseníase, tuberculose, sífilis e à febre amarela, os infantes e jovens no espaço escolar enfrentavam a desnutrição, diarréia, sarampo, coqueluche e difteria. Para combater tal quadro nosológico utilizou-se da abordagem de higiene escolar que se sustentava em intervenções e inspetorias das condições sanitárias e de saúde. (FIGUEREDO et al., 2010)

Atualmente, o Programa Saúde na Escola (PSE) foi materializado pelo decreto presidencial no 6.286 , de 5 de dezembro de 2007. Alinhado coma Carta de Otawa busca superar a lógica mecanicista, assistencialista e higienizadora para alcançar a prevenção, promoção e atenção à saúde do estudante, ampliando ao território escolar. Essas práticas, por sua vez, deixam de ser pontuais e passam a serem elaboradas pelo compartilhamento da comunidade escolar junto com às equipes de saúde da Atenção Primária. (BRASIL, 2007)

\section{0 "CAUSO" LOCAL}

Afinados com o exposto, enquanto profissionais de saúde e educação, temos vivenciado diversas angústias relacionadas à inabilidade dos educandos em realizar boas escolhas alimentares. Isso, evidenciados tanto pelos lanches trazidos de casa que apresentam baixa qualidade nutricional, quanto pela resistência dos estudantes na aceitabilidade de alimentos saudáveis quando ofertados no cardápio escolar.

Dessa forma, encontramos muitos infantes e adolescentes com prejuízos escolares, muito provável, acredita-se, pelo resultado do baixo consumo nutricional. Assim, surge uma preocupação de nós educadores e profissionais da saúde quanto ao crescente índice de obesidade infantil e maus hábitos alimentares, o que corrobora com maiores casos de doenças crônicas em escolares. (BOOG, 1997; ABESO, 2016; PEGOLO et al., 2010)

Por outro lado, o surgimento de baixo crescimento, peso reduzido ou distúrbios de maturidade podem resultar do consumo exagerado de alimentos pobres em nutrientes. Somado a isso, vemos o exagero do consumo de hipercalóricos, a ausência de práticas de atividades físicas, o que tem acarretado em crianças e jovens obesos (LUCERO et al., 2010).

Por conseguinte, foi uma queixa de uma professora quanto a qualidade do lanche trazido da casa do próprio estudante que culminou na elaboração do projeto "Promover Saúde educando Hábitos". Buscamos promover a reeducação alimentar como mecanismo de prevenção e promoção à saúde de uma escola municipal de crianças entre 09 e 12 anos (o estabelecimento contava com uma diretora, uma vice diretora e seis professores), de forma a integrar os componentes da estratégia de Saúde daFamília aos educadores da escola para uma integral abordagem de cuidado à comunidade escolar e seus familiares.

\section{PASSOS METODOLÓGICOS}

Discorre-se sobre um relato de experiência da implantação do projeto de intervenção "Promover Saúde educando Hábitos" em uma escola municipal de ensino fundamental I Itabunense. Esse trabalho foi realizado por profissionais da saúde e educação que compartilhavam do mesmo território vivo nas atuações e cuidados para com os adolescentes. Junto à isso, outro fator promotor foi a necessidade de implantar atividades vivenciais intervencionista à partir da proposta pedagógica do curso de 
Especialização em Saúde Escolar, estratégia do Núcleo Jovem Bom de Vida, da Universidade Estadual de Santa Cruz.

Nessa linha, desenvolveu-se uma pesquisa-intervenção que possibilitou a construção de espaços de problematização coletiva. Entendendo-a como uma investigação qualitativa e alicerçadas em perspectivas territoriais, transcende-se os enfoques tradicionais de pesquisa já que à mesma promove uma atuação transformadora da realidade vivida por quem compartilha do mesmo espaço. Dessa maneira, sendo um modo de Pesquisa participante que toma como princípio transformar-se para conhecer (ROCHA, 2013).

Nesse contexto, não existe uma ação imposta diante de grupos ou comunidades especificadas por pesquisadores neste modelo de perquirição. Na pesquisa participante tem-se uma relação entre os pesquisadores e o seu objeto investigado. Assim sendo, o que corroborou para a escolha do método de intervenção foi à possibilidade de se promover o envolvimento de toda à comunidade escolar, respeitando, aprendendo e se envolvendo na dimensão do pesquisado. Portanto, os resultados estariam diretamente vinculados à uma amplitude do convívio no processo de ensino-aprendizagem, valorizando a diversidade de saberes dos profissionais e da comunidade investigada. (SILVA E GRIGOLO, 2002)

O desenvolvimento da pesquisa-intervenção foi através do projeto: "Promover Saúde, Educando Hábitos", foi vivenciado em uma das sete escolas presentes no território adscrito à Unidade de Saúde (sendo uma gerida pelo Estado, quatro pelo município e duas pelo setor privado). Foi desenvolvido no período de março de 2018 até fevereiro do ano 2019. Desenvolvemos atividades voltadas à promoção da alimentação saudável buscando estratégias de mudanças fundamentadas no contexto social e escolar.

Dessa forma, este trabalho compreende o território escolar como um ambiente de aprendizagem, em que os discentes são considerados sujeitos ativos em seu progresso materializando-se em "Escola Ativa". Dentro desta perspectiva, os estudantes são tidos como sujeitos centrais e o processo de ensinoaprendizagem que imbrica teoria e prática em uma construção sócio-histórico compartilhada. (PNUB, 2017)

0 primeiro contato foi realizado com os pais. Utilizamos uma reunião de pais e mestres para apresentar o projeto aos mesmos e, para realizar uma avaliação diagnóstica, o que nos forneceu subsídios para o planejamento de ações, como as rodas de conversa. Foi aí que destacamos pontos de relevância para a comunidade escolar, sendo os mesmos trabalhados como temas nas rodas de conversa. 0 segundo momento foi aproveitar a Semana de Saúde na Escola como instrumento para ouvir os estudantes e também levantar assuntos pertinentes aos mesmos. E por fim,à confecção da Horta, cordéis e HQ foi à materialização de todo o percurso ediscussões sobre o tema de alimentação saudável.

\section{A EXPERIENCIAÇÃO DA EXPERIÊNCIA}

Em 2017, tinha-se 27 estados com adesões pactuadas ao Programa Saúde Escolar no Brasil, destes 4.787 municípios que mantinham 78.934 escolas com atuações do PSE já instituídas. Na cidade de Itabuna, tem-se 5.147 alunos, com total de escolas pactuadas 87 escolas, destas 3.839 sendo educando do ensino fundamental. (Brasil, 2017b; Brasil, 2017c)

0 projeto promover saúde educando hábitos acontece na forma de encontros durante o período do ano letivo de 2018, as datas foram pré determinadas no cronograma escolar tendo 4 horas de duração em cada turno nas salas de 4o e 5o ano do ensino fundamental I visando prevenção, promoção e os cuidados em saúde alimentar. Sabe-se que uma alimentação nutricional e saudável é um requisito fundamental para promoção à saúde, proporcionando uma afirmação plena do potencial de crescimento e desenvolvimento da criança e do adolescente para uma qualidade de vida eficaz. 0 aumento da prevalência e da severidade da obesidade neste público tem se destacado nas últimas décadas, principalmente pela manifestação precoce de doenças até então mais comumente observadas em indivíduos adultos, com dislipidemias e diabetes mellitus tipo II (Pegolo etal., 2010)

0 primeiro encontro aconteceu no dia 12 de maio de 2018, a princípio foi apresentado aos pais e professores o projeto, o qual foi aceito com entusiasmo pela comunidade escolar, no mesmo dia foi realizado um pequeno questionário com perguntas fechadas e abertas apenas para os pais, nesse questionário verificamos número de pessoas na residência, renda familiar, situação de saúde gerais e quais os alimentos eram oferecidos aos alunos.

Tivemos a semana de Saúde na Escola que foi pautada na concepção de acesso à saúde e nutrição e assim estimulando os educandoa hábitos saudáveis; tendo o apoio de uma equipe multidisciplinar composta 
por enfermeiros e estudantes, dentista, técnicos de enfermagem, auxiliar de consultório dentário e agentes comunitários. Nesse dia foi realizado avaliação do cartão vacinal, orientação e prática de escovação, buscamos identificar os valores antropométricos, desenvolvemos rodas de conversa sobre promoção de hábitos saudáveis. Durante essas atividades constatamos a necessidade de vacinação de alguns estudantes (o que foi realizado na própria escola pela equipe da UBS) orientação sobre o possível risco de obesidade e a possibilidade de enviá-los para outros procedimentos na Unidade. Em um outro momento ainda na semana de Saúde na Escola aproveitamos para aplicação de um outro questionário dessa vez para os estudantes, nessa abordagem podemos perceber a presença do consumo de alimentos industrializados, a falta da alimentação nos horários adequados e o quanto de muitos dos nossos educandos não realizam a primeira refeição.

Infelizmente a rede municipal de ensino de Itabuna entrou em greve, e devido esse imprevisto tivemos que parar nossos encontros durante alguns meses retornando no dia 17 de janeiro de 2019, segundo semestre do ano letivo 2019. 0 que acarretou em uma interrupção dos momentos de rodas de conversa, sendo necessário uma realocação dos encontros com os estudantes.

De volta à escola para as ações do Projeto, continuamos a utilizar da estratégia de rodas de conversa sobre a reeducação alimentar, somadas a uma aula expositiva dialogada ministrada pela equipe sobre o tema: Alimentação Saudável e Mudanças de Hábitos Alimentares. Durante essa construção coletiva utilizamos música, vídeos educativos e atividades lúdicas; os alunos participaram com perguntas, relatando conhecimentos prévios, observando-se o interesse dos educando ao assunto abordado e a importância de se discutir sobre a reeducação alimentar para uma possível transformação no estilo de vida.

No dia 09 de fevereiro de 2019, para construção de uma horta escolar escolhemos um lugar arejado com luz do sol na maior parte do dia, nesse espaço já havia uma horta que precisava ser revitalizada. Com o apoio dos professores, discente do 5ano e porteiro da Escola foi construída a horta de plantas medicinais e alimentares. Através dessa intervenção observamos a euforia dos educandos no contato com a terra, na limpeza ena reutilização de vasilhas "PET" para vasos.

No mês de março buscando a interdisciplinaridade tivemos momentos vivenciais em sala de aula junto aos professores de História, Ciências e Português, cujo a finalidade foi trabalhar à produção textual e, aproximá-los da realidade vivida pelos mesmos. Realizaram um mini concurso entre os alunos do 4o e 5o ano proporcionando aos alunos contato com o gênero textual cordel e história em quadrinho (HQ) produzido de maneira lúdica e criativa momentos de construções pessoais baseados em textos fundamentados em nossas atividades de intervenção: promover saúde educando hábitos.

\section{DIALOGANDO COM A EXPERIÊNCIA}

A alimentação saudável é um assunto que deve ser discutido nos diversos territórios escolares, visto que crianças e adolescentes podem fortalecer hábitos e tomadas de decisões mais harmoniosas afinadas com a disponibilidade de alimentos e recursos econômicos. (ZANCUL, 2008)

O número de crianças e adolescentes (de 5 a 19 anos) obesos em todo o mundo aumentou dez vezes nas últimas quatro décadas. Se as tendências atuais continuarem, haverá mais crianças e adolescentes com obesidade do que com desnutrição moderada e grave até 2022, de acordo com o novo estudo do Imperial College London e pela Organização Mundial da Saúde - OMS (10/10/2017). 0 estudo foi publicado na revista The Lancet um dia antes do Dia Mundial da Obesidade, celebrado em 11 de outubro.

Sendo um processo lento e contínuo os resultados obtidos foram satisfatório tanto na produção, quanto na finalidade do projeto. 0 Brasil aos poucos vêm se dando conta da importância da reeducação alimentar nos espaços escolares, no combate a doenças crônicas não transmissíveis e na obesidade infantil, estudos têm mostrado que projetos de intervenções com prazos menores são pouco eficazes para desenvolver hábitos saudáveis na vida dos escolares, no entanto, se houver atividades a longo prazo envolvendo pais e a comunidade pode surtir efeitos benéficos à saúde dos estudantes, promovendo o aumento de atividades físicas, a um consumo de alimentos mais nutritivos e a diminuição de tempos gastos em atividades sedentárias como: games, redes sociais e televisão. (SHIRLEY et al., 2015).

Diante das respostas do questionário foi possível identificar um alto índice do consumo de alimentos com baixo valor nutricional, o que corrobora, junto com à ausência ou reduzida realização de atividades físicas, a um agravamento da saúde dos escolares. Situação essa, evidenciada através de lanches trazidos de casa com baixa qualidade nutricional e pela grande resistência dos discentes na aceitabilidade de lanches e refeições mais saudáveis quando ofertados no cardápio escolar. 
A concepção do Programa de Saúde na Escola visa a redução das vulnerabilidades vividas por estudantes e enriquece o binômio ensino-aprendizagem. Contribuindo, desse modo, para uma integral formação na educação básica além de operacionalizar a prevenção, promoção e os cuidados em saúde. (BRASIL, 2007; BRASIL, 2017a)

No decorrer das ações da semana da saúde na escola houve práticas coletivas sobre promoção de hábitos saudáveis. Como resultado tivemos práticas da escovação na própria escola, vacinação de 85 alunos e checagem de cartão vacinal, com a possibilidade de realizar a vacinação na escola pôde-se, também, ampliar o direito à saúde do professor e apoiadores levando-se em consideração os determinantes de saúde vividos no local de trabalho. Tal experiência impactou diretamente na vigilância a saúde do trabalhador, podendo contribuir para um cuidado que amplia sua atuação não somente curativista, mas principalmente, preventiva. (VASCONCELOS et al, 2017)

Nas rodas de conversa sobre reeducação alimentar tal experienciação aconteceu para motivar à imersão dos sujeitos de direito a se engajarem no ato de transformar a realidade à partir de seus territórios, vencendo condicionantes sociais e de saúde em encontros dialógicos. E assim, os mesmos participaram com perguntas, relatando conhecimentos prévios e demonstrando interesse ao assunto abordado. Durante este evento os discentes tiveram oportunidade de conhecer tipos e qualidades de alimentos e sua repercussão na saúde, como resultado, obtivemos alunos mais informados e incentivados a diminuir o consumo de alimentos pobre em nutrientes. (SAMPAIO et al, 2014)

A elaboração de uma horta suspensa surge de uma parceria junto aos alunos do curso bacharelado interdisciplinar em Saúde (BIS) de uma Universidade local. Os professores e discentes do 5o ano se envolveram e se engajaram na limpeza das garrafas pet's recicladas para confecção do jardim suspenso; Além disso cada sala ficou responsável por cooperar com o projeto trazendo mudas de plantas comestíveis e medicinais utilizadas pelos seus familiares. No fim obtivemos mudas de Alecrim (Rosmarinus officinalis), Tomates de variados tipos (Solanum lycopersicum), Quiabo (Abelmoschus esculentus), Berinjela (Solanum melongena), Coentro (Coriandrum sativum), Salsa (Petroselinum crispum), Variados tipos de Alface (Lactuca sativa), cebolinha (Allium schoenoprasum) e muitas outras.

A interação do grupo de professores foi motivada pela responsabilidade em adquirir à terra vegetal para o cultivo das plantas. Para Morgado (2006), A horta inserida no ambiente escolar pode ser um laboratório vivo que possibilita o desenvolvimento de diversas atividades pedagógicas em educação ambiental e alimentar unindo teoria e prática de forma contextualizada, auxiliando no processo de ensino aprendizagem e estreitando relações através da promoção do trabalho coletivo e cooperado entre os agentes sociais envolvidos.

A construção da horta escolar teve como resultado à sensibilização em plantar o produto que vai à própria mesa, empoderando sujeitos e promovendo mudanças de hábitos que com certeza mudarão o meio, atividade que pode ser inserida no convívio de cada um dos educando, educadores e demais participantes.

Em nosso último encontro os professores foram convidados à participar do concurso, a equipe do projeto apresentou o mesmo traçando paralelo com às próprias vivências dos docentes. Ao observar à qualidade do lanche trazido de casa, como salgados, salgadinhos e refrigerantes, ou ainda, na negativa de alunos ao lanche oferecido pela escola, este resultado da intervenção de uma nutricionista e merendeiras que elaboravam um cardápio próprio para o adolescente.

Optamos por realizar este concurso, por considerarmos a arte um elemento através do qual os alunos pudessem expressar de forma leve e lúdica o conhecimento produzido durante o projeto, além de durante estas produções reelaborarem o que aprenderam e se apropriarem deste saber de forma mais significativa.

Freitas ( 2006) apontou que:

"A educação através da arte como expressão instiga a interação com o conhecimento, como também uma capacidade de reaprender através da sensibilidade e da percepção de mundo, dando vazão no ato de criar com uma liberdade inovadora, indo além de conhecimento pessoal." (Sousa, 2008 apud Freitas, 2006)

Os produtos foram coletados, professores e equipe votaram nos três melhores trabalhos, inicialmente adotarmos à estratégia de premiar à todos, mas os próprios professores optaram por restringir à premiação para valorizar os que mais se dedicaram. No fim, os melhores textos foram premiados o que 
motivou ainda mais os alunos a participarem, se envolverem e declamar suas obras.

Assim experienciamos a aproximação da Escola à Unidade de Saúde. Obtivemos mais interação e cooperação dos profissionais da unidade na instituição escolar em busca de promover hábitos saudáveis, transcendendo inclusive para outras abordagens do cuidado. À Escola tornou-se, também, uma porta de entrada para à Atenção Primária, visto que materializa à acessibilidade ao estudante e demais componentes da população escolar. Como exemplo, otimizou-se consultas com profissionais da unidade ou à especialistas, ou ainda à realização de exames e direcionamentos para outras instâncias da rede.

\section{UMA PINCELADA EM TRÊS PONTOS: PESQUISA, ENSINO E EXTENSÃO}

Os movimentos e intercâmbios efetivados por momentos de dispersão no decorrer da pós-graduação contribui para a atuação das universidades nas dimensões do ensino, pesquisa e extensão. Junto à isto, imerge o estudante em experienciações de grande heterogeneidade cultural, o que permite um processo ensino-aprendizagem "dual" e ativo.

Entendendo o espaço da pós-graduação como um local em que se acentua à pesquisa, esta, não deve está dissociada do território circunvizinho. Dito isto, a extensão é o instrumento promotor da descolonização do saber, visto que, integra o ensino à pesquisa de modo compartilhado. Além disso, fomenta uma renovação da Universidade, já que o conhecimento científico dialoga com as questões sociais vigentes. (MOITA et al, 2009)

Neste processo, pode-se perceber que o ensinar transcende a transmissão de conhecimento na sala de aula, concomitantemente, o processo de ensino-aprendizagem engloba à pesquisa que quando vinculada à responsabilidade social, objetiva à extensão. Portanto, as três dimensões de atuação da Universidade são indissociáveis. (SLEUTJES,1999)

E assim, uma Universidade somente se torna viva quando à construção do conhecimento transcende à educação tradicional e bancária. Isto porque à aprendizagem parte do aluno, quando o mesmo se envolve e resgata saberes presentes no seu espaço cultural. De modo sincrônico, também o preceptor aprende durante o processo de ensino-aprendizagem, sendo um aprendizado construído coletivamente, por isso dual. Junto à isto, sendo ativa quando o aprendizado parte de problemas e situações vividas pelos alunos. E assim, com uma única pincelada as experiências de dispersão conseguiram unir os três pontos vitais para as Instituições de ensino na atualidade, são eles: Ensino, Pesquisa e Extensão.

\section{CONSIDERAÇÕES FINAIS}

Com tudo que foi exposto, a ação conjunta para co-construir o Projeto Promover Saúde Alimentar no espaço Escolar, institucionaliza, localmente, a portaria no 1010/06. Da parceria entre Escola e UBS potencializa-se a promoção a alimentação saudável de modo transversal, catalisando assim o processo de ensino-aprendizagem de maneira mais significativa pois toma-se como ponto de partida experiências dos próprios estudantes.

E assim, promove-se uma autonomia do sujeito, tanto para os estudantes quanto para os professores. E com isso, intervém-se integralmente na co-responsabilização do processo cuidado-saúde-doença, visto que os sujeitos deixam de ser "pacientes" para se tornarem "ativos" quanto à intervenção no cuidado alimentar.

Por fim, a vivência da dimensão extensão no Programa de Saúde Escolar descoloniza saberes na medida que nos expôs a pesquisa-intervenção dirimindo distâncias entre saberes e viabilizando o ensino na dimensão escolar. De um modo mais transformador, já que à Escola Ativa empodera não só os pesquisados, mas os pesquisadores.

\section{REFERÊNCIAS}

[1]. ABESO. Associação Brasileira para o Estudo da Obesidade e da Síndrome Metabólica Diretrizes Brasileiras de Obesidade 2016. 4.ed. São Paulo. In: <http://www.abeso.org.br/uploads/downloads/92/57fccc403e5da.pdf> Acesso em: 12 fev. 2018.

[2]. BOOG, M.C.F. Educação nutricional: passado, presente, futuro. Revista Nutrição. v.10,n.1, 1997. p.5-19. In: <https://www.unifg.edu.br/wp-content/uploads/2015/06/Educa\%C3\%A7\%C3\%A3o-Nutricional-passado-presentee-futuro.pdf> Acesso em: 12 fev. 2018. 
[3]. BRASIL.Portaria Interministerial № 1.010, DE 08/05/2006 - Institui as diretrizes para a Promoção da Alimentação Saudável nas Escolas de educação infantil, fundamental e nível médio das redes públicas e privadas, em âmbito nacional. 2006. In: <http://bvsms.saude.gov.br/bvs/saudelegis/gm/2006/pri1010_08_05_2006.html> Acesso em 15 mar 2018.

[4]. BRASIL. Lei no 11947, de 16 de junho de 2009 - Dispõe sobre o atendimento da alimentação escolar e do Programa Dinheiro Direto na Escola aos alunos da educação básica; altera as Leis nos 10.880, de 9 de junho de 2004, 11.273, de 6 de fevereiro de 2006, 11.507, de 20 de julho de 2007; revoga dispositivos da Medida Provisória no 2.17836, de 24 de agosto de 2001, e a Lei no 8.913, de 12 de julho de 1994; e dá outras providências. 2009. In: <http://www.planalto.gov.br/ccivil_03/_ato2007-2010/2009/lei/l11947.htm> Acesso em 15 mar 2018.

[5]. BRASIL. Dispõe sobre o atendimento da alimentação escolar e do ProgramaDinheiro Direto na Escola aos alunos da educação básica; altera as Leis nos 10.880, de 9 de junho de 2004, 11.273, de 6 de fevereiro de 2006, 11.507, de 20 de julho de 2007; revoga dispositivos da Medida Provisória no 2.178-36, de 24 de agosto de 2001, e a Lei no 8.913, de 12 de julho de1994; e dá outras providências. 2009. In: <http://www.planalto.gov.br/ccivil_03/_ato2007-2010/2009/lei/l11947.htm> Acesso em 15 mar 2018.

[6]. BRASIL. Nota Técnica nº9/2017 - Coordenação-Geral de Alimentação e Nutrição/Departamento de Atenção Básica/Secretaria de Atenção Básica/Ministério da Saúde. Brasília, DF, 02 mai. 2017.

[7]. BRASIL. Ministério Da Saúde. Secretaria De Atenção À Saúde. Departamento De Atenção Básica. Coordenação-Geral de Alimentação e Nutrição; NT número 69/2017, Grupos de Trabalho Intersetorial do Programa Saúde na Escola; 1-4; 2017b.

[8]. BRASIL. Ministério Da Saúde. Secretaria De Atenção À Saúde. Departamento De Atenção Básica. Programa Saúde Na Escola. Termo De Compromisso Municipal Do Programa Saúde Na Escola (PSE) - № 02914801472; 1-3; 2017c.

[9]. BRASIL. Decreto ${ }^{\circ} 6286,05$ de dezembro de 2007. Institui a Programa Saúde na Escola, e dá outras providências. Brasília,DF, dez. 2007. In:<http://www.planalto.gov.br/ccivil_03/_Ato20072010/2007/Decreto/D6286.htm>. Acesso em 20 jan 2018.

[10]. BRASIL. Ministério da Saúde. Secretaria de Atenção à Saúde. Departamento de Atenção Básica. Guia alimentar para a população brasileira / Ministério da Saúde, Secretaria de Atenção à Saúde, Departamento de Atenção Básica. - 2. ed., 1. reimpr. - Brasília : Ministério da Saúde, 2014.

In:<http://bvsms.saude.gov.br/bvs/publicacoes/guia_alimentar_populacao_brasileira_2ed.pdf> Acesso em 12 fev. 2018.

[11]. CARVALHO, Fabio Fortunato Brasil de. A saúde vai à escola: a promoção da saúde em práticas pedagógicas. Physis: Revista de Saúde Coletiva. v. 25, n. 4, 2015. p.1207-1227.

[12]. FIGUEIREDO, Túlio Alberto Martins de; MACHADO, Vera Lúcia Taqueti; ABREU Margaret Mirian Scherrer de; A saúde na escola: um breve resgate histórico; Ciência e Saúde Coletiva, v.15, n. 2. 2010. p. 397-402.

[13]. MOITA, Filomena Maria Gonçalves da Silva Cordeiro; ANDRADE, Fernando Cézar Bezerra de. Ensinopesquisa-extensão: um exercício de indissociabilidade na pós-graduação. Revista Brasileira de Educação. v. 14, n. 41, Rio de Janeiro, 2009. p. 269-280.

[14]. ORGANIZAÇÃO MUNDIAL DE SAÚDE - OMS. Obesidade entre criançase adolescentes aumentou dez vezes em quatro décadas, revela novo estudo do Imperial College London e da OMS. Revista The Lancet. In: http://www.paho.orgo Acesso em 10 out 2017.

\section{[15]. ROBINSON, L.E.; WEBSTERE .K.; WHITT-GLOVER, M.C.; CEASERT G.;}

[16]. ALHASSAN S. Effectivenees of pre-school- and school-based interventions to impact weight-related behaviours in African Americanchildren and youth: a literature review. Obesity reviews. no15, 2014. p.5-25.

[17]. ROCHA, Marisa Lopes da; Pesquisa-Intervenção e a Produção de Novas Análises; Psicologia, Ciência e Profissão.no 23, 2003. p.64-73.

[18]. SHIRLEY Kaleena, RUTFIELD Rachel; HALL Nathanae; FEDOR, Nicholas; MCCAUGHEY Virginia; KRISTYN, Zajac; Combinations of Obesity Prevention Strategies in US Elementary Schools: A Critical Review. Primary Preventive. V. 36: 2015 . p 1-20; 2015. In: <http://link.springer.com/article/10.1007/s10935-014-0370-3> Acesso em 12 mar 2018.

[19]. SILVA, Dayanne Caroline de Assis et al. Percepção de adolescentes sobre a prática de alimentação saudável. Ciência e Saúde Coletiva. v. 20, n. 11, 2015. p.3299-3308

<http://dx.doi.org/10.1590/1413-812320152011.00972015.>

[20]. SLEUTJES, Maria Helena Silva Costa. Refletindo sobre os três pilares de sustentação das universidades: ensino-pesquisa-extensão. Revista de Administração Pública. v. 33, n. 3, Rio de Janeiro, 1999. p. 99 a 101 
[21]. ZANCUL, Mariana De Senzi. Orientação nutricional e alimentar dentro daescola: Formação de conceitos e mudanças de comportamento. Tese (Doutorado em Ciências Nutricionais) UNIVERSIDADE ESTADUAL PAULISTA - FACULDADE DE CIÊNCIAS FARMACÊUTICAS. Araraquara, 2008. In:

<http://www2.fcfar.unesp.br/Home/Pos-graduacao/AlimentoseNutricao/mariana_zancul-completo.pdf> Acesso 13 mar 2019 


\section{Capítulo 9}

\section{Uso do Lian Gong na promoção da saúde em uma escola pública de um município do Sul da Bahia}

\section{Caroline Dias Brandão}

Marleide Mateus de Jesus

Samanta Santana da Silva

Valdeir Almeida Santos

Nayara Alves Severo

João Luis Almeida da Silva

Resumo: 0 objetivo do presente estudo é de relatar a experiência sobre o processo de ensino-aprendizagem da prática de Lian Gong como promotor da saúde entre educadores de uma escola. Trata-se de um relato de experiência a partir das observações do processo desenvolvido na implementação da prática durante o período de janeiro a setembro de 2020 com 9 participantes de uma Escola Municipal de Ensino Fundamental em um município do sul da Bahia. A implementação se deu por profissionais de saúde e da educação, articulando as duas dimensões com as Práticas Integrativas e Complementares através do Lian Gong. Os resultados foram coletados pelos pesquisadores através de encontros presenciais e por aplicativo remoto, em que foi observado o processo de ensino-aprendizagem por meio de rodas de conversa no espaço escolar, ensino da prática do Lian Gong compartilhados presencialmente na escola e em formato remoto (online) em suas residências. Em função da pandemia, o processo de implementação e consequentemente o ensino-aprendizagem ficou prejudicado, porém, mesmo com a evasão pelos motivos de sobrecarga com ensino remoto, entre outras atividades, os participantes manifestaram melhoria em sua saúde física e mental. Para os pesquisadores, o processo foi permeado por frustrações, mas promoveu reflexões e o desafio de reestruturar-se e reinventar-se na adversidade, repensando inclusive o papel da educação e da saúde no cenário que se apresentou.

Palavras-Chave: Lian Gong, Saúde Escolar, Práticas Integrativas e Complementares, Promoção da Saúde 


\section{INTRODUÇÃO}

Nas últimas décadas a sociedade mudou muito, reflexo do processo de intensificação da integração econômica e política internacional, ou seja, a globalização tem gerado impacto muito grande na vida das pessoas. A vida acelerada e a constante busca de realizações pessoais de forma individualista e competitiva, em alguns casos, tem trazido impacto negativo nas relações sociais, desestrutura financeira familiar e, como consequência, o corpo e a mente das pessoas têm sido severamente abalados. Segundo Burgos (2012), quanto ao que se refere ao educador, a relação com os alunos, são evidenciados choques entre realidades muito distintas, por vezes implicam no distanciamento social e psicológico. Esta distância produz a ideia de uma distinção entre nós, educadores e um eles educandos, que vem a interferir negativamente na mediação cultural e social da escola, reduzindo espaço para uma relação mais empática entre os dois grupos.

Com os desgastes também provocados por intensa jornada de trabalho, no caso dos profissionais de educação em lidar com diferentes tipos de alunos e de educação familiar, sem contar outros fatores como a violência que tem chegado severamente nas escolas, o risco de morte tem causado medo e temor a esses profissionais envolvidos.

"A concorrência do tempo dos professores destinado às inúmeras tarefas escolares com o tempo para as atividades da vida extratrabalho talvez esteja restringindo os períodos para o autocuidado, o lazer, as atividades culturais, as relações com os amigos e a família. Desequilíbrios dessa natureza perturbam o necessário repouso e recuperação após as jornadas nas escolas e quando finalizadas as tarefas extraclasse, com prováveis efeitos negativos sobre a saúde. Num ciclo vicioso, cansados ou doentes, os professores terão menos recursos para responder às demandas da sala de aula." (ASSUNÇÃO e ABREU, 2019).

Segundo Zanelli e Kanan (2018), são observados como fatores de risco mais comuns: o assédio moral, sexual e a violência no trabalho; a adição ao trabalho; o consumo abusivo de substâncias; a corrupção; o estresse. Ensinar na conjuntura atual da sociedade se constitui numa tarefa estressante e desafiadora, pois este panorama atual tem adoecido os profissionais de educação, levando -os muitas vezes ao encerramento precoce da carreira ou afastamento por longo período por agravamento de suas condições de saúde física e mentais. Patologias como síndrome de Burnout; os transtornos do humor e de ansiedade e o suicídio, tem se tornado mais comuns de acordo com a severidade dos danos ou agravos definidos pela intensidade e tempo de exposição aos fatores de risco.

"No cenário contemporâneo, não basta a escola se preocupar apenas com as relações de ensino e de aprendizagem, com foco na permanência em sala de aula de alunos e professores. As unidades escolares precisam se preparar para enfrentar contextos adversos, pois são inúmeras as dificuldades para implementar práticas e posturas adequadas ao enfrentamento das situações de indisciplina juvenil e de conflitos, o que pode comprometer as chances de aprendizagem de milhares de crianças e jovens." (MARTINS, 2016)

A docência é, sem dúvida, um dos mais importantes e necessários ofícios do mundo na preparação de indivíduos reflexivos e educados. Sabe-se que para educar bem e ser um bom artífice na construção de valores humanos positivos, é imprescindível que o professor esteja bem; porém se ele é intensamente exposto a estressores laborais e não consegue enfrentá-los eficazmente, vai se desgastando psiquicamente e perdendo o entusiasmo com o trabalho (BURGOS, 2012).

Gasparini et al (2005), salienta que as circunstâncias que envolvem as condições de trabalho, sob as quais os docentes mobilizam as suas capacidades físicas, cognitivas e afetivas para atingir os objetivos da produção escolar, podem gerar sobre-esforço ou hipersolicitação de suas funções psicofisiológicas quando não existe tempo suficiente para a recuperação, são desencadeados ou precipitados os sintomas clínicos que explicariam os índices de afastamento do trabalho.

A partir dessa problemática é importante buscar estratégias que possam intervir nos conflitos do ambiente escolar e perceber as condições de estresse do trabalhador em uma perspectiva de promoção da 
saúde. Sendo assim, um dos fatores que merecem atenção, para qualidade de vida no trabalho e nas relações, é a prática de atividades corporais que possam promover bem estar ao corpo e a mente.

Segundo Freire (1996), se a educação não pode tudo, alguma coisa fundamental a educação pode. Se a educação não é a chave das transformações sociais, não é também simplesmente reprodutora da ideologia dominante, considerando a tônica da violência e do sobre esforço dos educadores em seu processo de trabalho se faz necessário, educá-los para lidar com o estresse advindo do processo de trabalho, considerando o reforço no autocuidado e oferecendo instrumentos que proporcionem alívio de tensões físicas e mentais.

A Medicina Tradicional Chinesa (MTC) e outras práticas integrativas em saúde, construídas a partir de uma concepção holística, vêm nesse sentido contribuir para repensar a lógica da organização dos serviços de saúde, promover a integralidade, ampliar o alcance das condutas terapêuticas e o espectro das medidas preventivas e de promoção da saúde. (BOBBO et al, 2018) Pensando nessa proposta, percebemos a importância de atuar no uso das Práticas Corporais, na qual se destaca o Lian Gong , que é uma prática da Medicina Tradicional chinesa composta por exercícios que podem ser praticados ao ar livre, como também em casa, e que ajudam a aliviar dores, estresse, melhorar o humor e a disposição, dentre outros benefícios.

Segundo Livramento et al (2010), o Lian Gong é uma ginástica terapêutica chinesa que se caracteriza por um conjunto de três séries de 18 exercícios terapêuticos e preventivos que alia os conhecimentos da medicina Tradicional Chinesa.

Os mesmos autores complementam que o Lian Gong traz uma proposta de exercícios adaptada ao nosso tempo. São exercícios considerados de fácil aprendizagem, através de movimentos que permitem abrir, fechar, expandir e recolher o corpo que induzem uma simultaneidade da respiração, de forma espontânea.

No Brasil, a repercussão da introdução do Lian Gong mostrou que esta técnica tem enriquecido as práticas integrativas desenvolvidas no sistema público de saúde, contribuindo para a qualidade de vida (BOBBO et al, 2018). Nesse contexto, sabemos que a escola é o ambiente que permite interação, socialização e práticas voltadas à coletividade; portanto, propício para desenvolver algo novo e motivador que permita a promoção da saúde dos educadores.

Dessa forma, acredita-se que promover ações de saúde na escola, utilizando-se da prática do Lian Gong possibilite reduzir desgastes emocionais e promover um melhor gerenciamento de conflitos entre profissionais da educação e alunos.

Acredita-se que a busca do equilíbrio da saúde no âmbito escolar se faz necessária, uma vez que, compreende o bem estar físico e emocional dos envolvidos, o qual se torna imprescindível para o desenvolvimento das atividades e enfrentamento das dificuldades no cotidiano de aprendizado. Contudo, evocar uma experiência com uma prática integrativa corporal na escola requer muito esforço e disposição, porém é possível se instaurar processos muito interessantes no cotidiano escolar.

Na articulação entre a Unidade Básica de Saúde e a escola, que compartilham o mesmo território vivo, perceberam-se relatos de desgastes emocionais, variações de humor e impaciência no relacionamento entre profissional da educação e alunos. 0 que motivou ainda mais a implementação de uma proposta de promoção da saúde através de uma das práticas corporais integrativas chinesa, previstas também no arcabouço das políticas de saúde do Sistema Único de Saúde.

Sendo assim, o objetivo deste estudo é de relatar a experiência sobre o processo de ensino-aprendizagem da prática de Lian Gong como promotor da saúde entre educadores de uma escola pública.

\section{METODOLOGIA}

Trata-se de um relato de experiência, elaborado a partir das observações e do replanejamento das ações dos pesquisadores sobre a implementação e o processo de ensino-aprendizagem da prática de Lian Gong entre os profissionais de educação de uma Escola de Ensino Fundamental de um município do sul da Bahia, no período de 10 de janeiro a 21 de setembro de 2020.

A proposta inicial era desenvolver a atividade com 13 profissionais da educação, porém com a falta de renovação do contrato de alguns profissionais da escola durante o mês de março de 2020, o número reduziu perfazendo um total de 9 pessoas.

A implementação da proposta seria por encontros presenciais; contudo, os pesquisadores foram desafiados pelo isolamento social em virtude da pandemia do novo coronavírus. Sendo assim, houve a 
necessidade de utilização de recursos digitais online e adequar as estratégias de execução do projeto, contando com a corresponsabilidade assumida pelos participantes que se comprometeram a tentar seguir o cronograma de atividades.

A capacitação foi desenvolvida em 9 semanas da seguinte forma: o Lian Gong possui 3 partes e cada uma delas foi subdivida em 6 exercícios. Cada grupo de exercícios foi aprendido e executado em 3 oficinas de 1 hora, 1 vez por semana. A execução dos exercícios corretamente foi avaliada através de observações ao longo do desenvolvimento das oficinas com as readequações pertinentes, sempre de forma cumulativa até completar a sequência de 18 exercícios. 0 registro das oficinas foi em diário de campo. Nas oficinas foi estimulada a prática pelo menos 3 vezes na semana, durante o período de 15 dias após capacitação. Após esse período, foi avaliado o processo e os efeitos da prática.

Antes da prática dos exercícios, estavam no planejamento a realização de dois questionários: um pré teste e o outro seria pós teste. 0 pré teste foi realizado presencialmente no mês de fevereiro e contou com a participação de todos os participantes do estudo, no qual foi-se percebido em uma boa parte dos mesmos, a presença de dores corporais. Mas nem todas as perguntas foram respondidas. Alguns participantes não quiseram responder, até porque não era obrigado a tomar as questões em sua totalidade. No entanto, houveram dificuldades para avaliar as necessidades da equipe escolar de um modo em geral.

O questionário serviria de embasamento para estimular a participação na aplicação das metodologias; o questionário aplicado requeria informações a respeito do conhecimento prévio da prática do Lian Gong, se o profissional era portador de processos dolorosos ou tensionais de origem osteomuscular, cuidados que tomam ao sentir essas dores e se os mesmos atribuem esses processos dolorosos a causas emocionais ou somente físicas. Além disso, o questionário servia para avaliar o contexto inicial antes do aprendizado da prática de Lian Gong e seria aplicado ao final, para avaliar seus efeitos no cotidiano escolar e na saúde dos profissionais.

É importante contextualizar que a proposta inicial era de um projeto de pesquisa intervencionista de caráter qualitativo e descritivo, com intuito de analisar os efeitos relacionados à saúde antes e após o aprendizado do Lian Gong, a partir da ótica dos profissionais da educação. Contudo, foi importante revisar a cronologia das ações propostas e a história da chegada do novo coronavírus que causou a pandemia da COVID-19, que inviabilizou a formatação metodológica inicial e consequentemente a avaliação final pósteste.

\section{RESULTADOS E DISCUSSÃO}

Cronologicamente as atividades presenciais relacionadas à pesquisa deram início em Janeiro de 2020 onde ocorreu uma reunião com os profissionais da escola, na qual foi apresentado o Projeto sobre Lian Gong e os benefícios que a prática poderia proporcionar a saúde. Ao final, todos os profissionais presentes, aceitaram participar da prática. Agendamos um segundo encontro.

0 segundo encontro aconteceu em dezoito de fevereiro de 2020, no espaço da Escola Municipal, onde realizamos um momento socializante, com práticas de sensibilização para percepção da respiração, utilizando técnicas de yoga e auto massagem, para estimular a auto percepção corporal seguida de um estado de relaxamento, com o uso de incenso, óleos essenciais de menta e eucalipto, músicas instrumentais, menor incidência de luz direta para criar um ambiente mais acolhedor e tranquilo em uma das salas da escola, ao término da prática foi realizada uma meditação silenciosa ao som do orin por cinco minutos. Após este momento, com todos mais descontraídos e sintonizados, foi aplicado o questionário pré-teste.

Considera-se que a promoção de saúde é um processo em que a comunidade pode ser capacitada para agir proativamente na conquista das melhorias necessárias para sua saúde, assim como, para ampliar sua qualidade de vida tanto individual quanto coletivamente. Nesse encontro também foram reafirmados os benefícios da prática física do Lian Gong e sua continuidade como rotina diária, reforçando o convite para a prática em grupo, o que inicialmente deixou todas as participantes animadas.

A seguir, ficou pré acordado entre os profissionais e os pesquisadores que no dia dez de março pela manhã, teríamos um terceiro encontro no mesmo local. Nesta oportunidade, foi realizada mais uma vez uma dinâmica de respiração meditativa e relaxamento, seguida da realização da primeira série do Lian Gong, com seis exercícios, com a participação de todos os profissionais do núcleo escolar.

Pode-se perceber inicialmente que os encontros presenciais foram significativos, o qual possibilitou a curiosidade e vontade de realizar a prática por parte da maioria dos trabalhadores envolvidos. Mas depois 
da necessidade de haver encontros remotos face à epidemia do novo coronavírus, percebeu-se uma evasão, levando a uma desmotivação dos participantes em dar continuidade à prática.

Segundo Marques et al (2017), as práticas educativas bem-sucedidas resultam da mediação do social e do afetivo na constituição dos sujeitos que desenvolvem essas práticas. Portanto o processo de aprendizado quanto às práticas corporais necessita ser construído constantemente, diante disso, observou-se a importância dos encontros presenciais como uma ferramenta de motivação frente ao interesse em realizar a ginástica terapêutica. 0 autor afirma ainda que, do desenvolvimento humano, contribuem para a expansão de afetos alegres que potencializam mentes e corpos humanos a agirem com compromisso social.

Ressalta-se que a oportunidade de realizar exercício físico, como de provocador de autoconhecimento, percepção das limitações do corpo físico que está submetido e impactado pelo estresse da vida profissional e rotina diária trouxe nesta oportunidade de encontro comentários sobre aumento da autoestima estimulando iniciativas de maior autocuidado. Foram de fato percebidas limitações de movimento e queixas referentes ao enrijecimento articular e muscular; dores na região do pescoço, ombros e região da coluna, fomos questionadas se os exercícios poderiam aliviar essas dores assim como também foi percebida por algumas das participantes a dificuldade relativa a coordenação motora na realização dos movimentos orientados devido ao sedentarismo e falta de costume com aquele tipo de exercício.

A experiência de realização de uma ginástica terapêutica até então desconhecida pelos participantes, trouxe curiosidade e interesse pela prática, principalmente quando se demonstrou os efeitos positivos do Lian Gong. A proposta inicial de realizar os encontros para prática no espaço da escola, trouxe a possibilidade de esvaziar as tensões da rotina antes dos profissionais retornarem aos seus domicílios, ideia amplamente aceita por todos.

Livramento et al (2010,p. 84) refere que "a prática regular do Lian Gong permite a movimentação adequada para liberar músculos, fáscias, ligamentos, tendões, melhorando e expandindo a amplitude de movimentação das articulações".

Foi percebido que ao reforçar estas características da oficina proposta pelo grupo, as orientações e a troca de ideias foi muito bem aceita pelas participantes que se mostraram ansiosas pelas próximas oficinas.

Nesta oportunidade, foram realizados com as participantes os movimentos da primeira série do Lian Gong voltados para cabeça e pescoço, os quais despertaram sensações de alívio na musculatura do pescoço, expansão da musculatura peitoral, induzindo o praticante a olhar para longe na lateral, estimulando sua percepção do ambiente, provocando a mobilidade dos ombros e costas, podendo irradiar dos ombros para os braços e cintura ao estender os braços para cima.

A partir do dia 20 de março de 2020 , não conseguimos dar continuidade às atividades presenciais, devido ao isolamento social e fechamento das escolas, por conta do Decreto Estadual № 19529 de 16/03/2020 o qual restringia as atividades laborais e aglomerações como forma de reduzir a propagação do novo coronavírus, logo, por conta dessa situação, foi necessário reorganizar a metodologia de aplicação das práticas do Lian Gong as atividades projeto precisaram ser suspensas temporariamente, sem determinação de prazo para retorno, houve então, um intervalo de aproximadamente seis meses para que fosse possível retomar os planejamentos referentes a continuidade e encerramento do projeto, enquanto os docentes da Escola estavam em fase planejamento e execução de home office. Esta pausa necessária, trouxe novos desafios dentre os quais estavam: como realizar as práticas remotamente? os docentes enxergariam o projeto como sobrecarga de atividades?, como garantir a adesão destes profissionais às atividades propostas? haveria desmotivação na adesão dos docentes devido ao tempo passado entre a proposta da atividade e sua execução?

Contudo, a expectativa sobre os rumos da pandemia deixaram o projeto com um espaço de tempo ocioso. Após 3 meses, foi retomado, mas requeria uma nova organização e planejamento. Nesse sentido, a proposta deu continuidade à repactuação com os professores, onde foram oferecidas alternativas através de encontros síncronos utilizando a plataforma Google Meet, foram questionados quanto aos dias e horários que fossem compatíveis com sua participação . Em acordo com esta proposta foi acertado que as práticas aconteceriam uma vez por semana nas segundas feiras às 17:00 hs iniciando em 27 de julho, encerrando em 14 de setembro.

A primeira aula remota foi realizada dia 27 de julho de 2020 então, a partir desse momento, foram percebidas dificuldades quanto à presença de todas as profissionais durante os encontros remotos. As ausências foram justificadas por razões como compromissos de trabalho concomitante ao horário das 
aulas, reuniões na mesma data dos encontros, atrasos de até trinta minutos, bem como dificuldade de acesso pela internet.

Desta forma, visando melhor adesão à proposta remota, os professores foram consultados sobre a possibilidade de novo horário e/ou dia, atentando para as dificuldades do trabalho em home office que estava sendo realizado no âmbito da escola, ajustando os calendários retomando o cronograma com os participantes, mas não houve muito sucesso e a evasão persistiu.

Seguindo o cronograma pactuado anteriormente, no dia 03 de agosto realizou-se a segunda oficina online oficina procedendo os movimentos da primeira série do Lian Gong, onde foi realizado um momento de respiração e relaxamento, seguido das orientações dos seis exercícios da primeira parte do Lian Gong.

A prática realizada neste encontro visou resgatar alguns conhecimentos remanescentes possivelmente adquiridos na prática presencial realizada em 10 de março. Os movimentos executados desta série foram: Movimento do pescoço, Arquear as mãos, Estender as palmas para cima, Expandir o peito, Despregar as asas e Levantar o braço de ferro.

Na semana seguinte, dia 10 de agosto, realizou-se a segunda oficina reforçando a aprendizagem da primeira série de movimentos, com a prática da respiração e dando sequência à primeira série do Lian Gong com os seis exercícios, e repetição dos mesmos perante a apresentação das dúvidas. Houve participação dos profissionais da escola em maioria e todos gostaram da atividade.

No dia 17 de agosto, deu-se sequência repetindo a primeira série com os seis exercícios. Neste encontro houve relatos dos participantes, referindo muita dificuldade em acompanhar os movimentos devido a adaptação ao método online. Decidiu-se então, a realização de uma filmagem, a qual foi disponibilizada no Youtube, contendo a série completa do Lian Gong, a fim de que pudessem acessar o conteúdo livremente para praticar. A experiência aconteceu no dia 15 de agosto.

No encontro seguinte, dia 31 de agosto, trabalhou-se com os participantes a segunda série dos exercícios de Lian Gong e prática de respiração. Os movimentos realizados nessa série foram: Empurrar o céu e inclinar para o lado, Girar a cintura e projetar as palmas das mãos, Rodar a cintura com as mãos nos rins, Abrir os braços e flexionar o tronco e Espetar com a palma para o lado. Estes movimentos são direcionados para dores nas costas e região lombar, nestes, as sensações de conforto são mais percebidas no pescoço e cintura, irradiando para os ombros, braços e dedos, as sensações vão irradiando para os ombros e costas, quando giramos o tronco impulsionando as palmas das mãos, expansão na região lombo sacra, alívio na coluna lombar e musculatura posterior das pernas com alívio no pescoço, ombros e cintura ao erguer os braços e ao curvar o tronco para pressionar o dorso dos pés com as mãos.

A cada movimento são percebidos novos grupos musculares sendo trabalhados e as percepções de relaxamento ao término da série se tornam mais evidentes, assim como as limitações físicas na execução das movimentações, o que pode ser compreendido como efeito da auto percepção corporal.

Em 10 de Setembro, no mesmo horário, foi conduzida a terceira série com seis exercícios do Lian Gong .Nesta terceira série encontra-se movimentos voltados para dores nos glúteos e pernas, dentre estes estão: Rodar os joelhos à direita e à esquerda, traz alívio na articulação dos joelhos e tornozelos; Flexionar as pernas e girar o tronco trabalha a região média da coxa da perna esticada, e no músculo quadríceps femoral da perna arqueada; Flexionar e esticar as pernas, ao entrar na posição de cócoras causa impressão de alívio nos músculos anteriores das coxas e nas articulações dos joelhos. Ao esticar as pernas alivia os músculos posteriores das coxas e panturrilhas; Tocar os joelhos e levantar as palmas este movimento gera percepção de bem-estar nos músculos gêmeos de ambas as pernas e também na cintura, ombros e pescoço; e por último, Passos marciais, que traz maior percepção sobre a incidência da distribuição do peso corporal nas pernas e tornozelos, trabalhando coordenação motora e equilíbrio.

No dia 14 de setembro foi realizado o último encontro online onde foi realizada a condução das três séries completas totalizando os 18 exercícios em Lian Gong.

Nota-se que durante os encontros os participantes estiveram a princípio muito animados e querendo aprender essa nova maneira de promover a saúde. Logo ao apresentar essa proposta de intervenção ao grupo, percebeu-se a alegria dos profissionais. Eles disseram que na escola todas as intervenções que aconteciam até então, sempre eram voltadas aos alunos ou a sua aprendizagem, mas que pela primeira vez apresentou-se um projeto onde os profissionais eram os protagonistas. Isso deixou a equipe criadora do projeto muito alegre.

No decorrer dos encontros observou-se que os docentes relataram estar sentindo melhora de desconfortos físicos como alívio de dores na coluna devido a prática dos exercícios de Lian Gong. 
Revelaram estar gostando tanto dos exercícios que pretendiam levar para sua prática diária. Percebe-se então, que mesmo com um quantitativo pequeno de participantes a prática desses exercícios trouxe satisfação.

Por outro lado, apesar do empenho em manter o planejamento do projeto, a equipe de pesquisadores percebeu que a avaliação dos efeitos do Lian Gong como previsto, não seria mais possível, pois a evasão nos encontros e a segmentação do aprendizado motivados pela questão do ensino remoto, dificuldades de acesso à internet, incompatibilidade de horários e compromissos, motivação e sobrecarga dos educadores formaram barreiras para uma análise processual avaliativa. Testar o aprendizado antes e depois e os efeitos do Lian Gong na saúde havia se esvaziado nessa enxurrada de fatores limitantes.

Mas, apesar de gerar frustração e incômodo para os pesquisadores, esse contexto serviu para compreender o impacto que a pandemia trouxe na reorganização da vida das pessoas e o quão isso foi gerador de outros processos de adoecimento, estresse e ansiedade. Ao mesmo tempo, produziu desacomodação, reinvenção e reestruturação frente às adversidades, portanto, o processo educacional vivenciado continuou com seu objetivo de transformar realidades - positivamente ou negativamente - isso depende das conjunturas que são consideradas e do olhar de cada um.

Lembrando que, possivelmente os outros componentes do núcleo familiar também deveriam neste período estar em adaptação para home office, a fim de garantir a privacidade necessária para que todos possam executar suas atividades profissionais e estudantis sem causar prejuízos à rotina dos familiares.

“O home office apresenta vantagens, pois permite melhor acomodação entre os horários dedicados ao trabalho e às responsabilidades domésticas e familiares, trazendo maior produtividade e melhor equilíbrio entre essas esferas. Ademais, sua adoção reduz os custos com o transporte casa-trabalho. Como desvantagem menciona-se a tendência à superindividualização do trabalho, o que pode gerar isolamento social, profissional e político. 0 aumento das horas dedicadas ao trabalho também é reportado como consequência negativa do home office." (LEMOS, BARBOSA e MONZATO,2021).

Desta forma, acredita-se que os profissionais da escola perceberam na sua rotina que as mudanças abruptas no processo trabalho doméstico versus rotina familiar versus home office que aconteceram sem o planejamento devido e acarretando sobrecarga de horários, compromissos e rotinas pouco compatíveis com qualidade de vida. Ao final de tudo, somando-se as atividades domésticas, pessoais e profissionais é adicionando a esta cena o receio de perder o vínculo empregatício por baixa produtividade aumentando então o número de fatores geradores de estresse.

Mesmo com a proposta de ser uma atividade que geraria bem estar e relaxamento para o corpo, as oficinas terminaram sendo mais uma atividade online a reduzir o tempo de descanso, expondo a intimidade de seu lar, demandando estar com a câmera aberta e uma boa apresentação pessoal perante colegas de trabalho e instrutores das oficinas.

Natural que ainda consideremos parte do contexto da evasão das atividades na modalidade online e ao vivo, as alterações da percepção da autoimagem, a autoestima e o autoconceito das participantes compreendendo que estes são fatores que podem impactar significativamente na capacidade de socialização dentro proposta oferecida pelo "novo normal".

A preocupação com ruídos característicos de cada lar, como interferências dos filhos e da vizinhança além da organização do espaço físico para realizar a atividade sem interrupções e preocupações com aparência física e questionamentos a respeito da habilidade e coordenação motora necessárias para realizar com perfeição os movimentos do Lian Gong, a vergonha da exposição das correções dos movimentos durante as práticas frente aos outros colegas, sentimento natural e compreensível do comportamento humano podem ter também contribuído para aumentar a evasão dos encontros.

A todo instante, houve a procura da contrapartida do compromisso compartilhado entre equipe de pesquisadores e profissionais da unidade escolar na execução das ações da pesquisa, visando proporcionar um bom processo de ensino e aprendizagem das práticas do Lian Gong, compreendendo que o alcance das metas propostas para o projeto dependia da adesão dos educadores. 
Tivemos dificuldades em realizar o pós teste devido à baixa adesão dos membros na participação, pois o processo avaliativo não seria suficiente com apenas três participantes assíduos, por vezes ainda com dificuldades de seguir mantendo a câmera ligada, para avaliar o desempenho no desenrolar da atividade e proceder com as correções dos movimento quando necessário, desta maneira, seguir o processo avaliativo com questionário se mostrou insuficiente e incoerente considerando a impossibilidade de sistematização da pesquisa.

Assim restou o desafio de repensar a atuação dos trabalhadores no âmbito das práticas integrativas e complementares, de maneira remota, consolidando a atuação destes profissionais na promoção e no cuidado em saúde.

Importante considerar que tudo isso gerou um reflexo na equipe de pesquisadores, causando frustração, pois mesmo quando houveram tentativas de reinventar as práticas tentando uma aproximação com a equipe, ainda percebendo neles a vontade de aprender, e mesmo assim, com anseio de compartilhar o conhecimento numa linguagem simplificada, trabalhando repetições dos movimentos, reforçando a importância do feed back para melhorar a comunicação, não foi obtido o resultado de alcançar maior frequência e melhor qualidade de participação dos envolvidos. A transformação dos condutores do processo educativo a partir da empatia na compreensão das dificuldades dos participantes no contexto da pandemia e observar, que mesmo com poucos relatos, o que ainda se dispuseram a continuar, conseguiram obter êxito na promoção de sua saúde.

\section{CONSIDERAÇõES FINAIS}

As expectativas em relação ao engajamento dos educadores nas práticas propostas com consequente aprendizado dos movimentos foram frustradas pela baixa adesão à proposta de atividade online, apesar da simplicidade da técnica, das repetições das séries e da disponibilidade das pesquisadoras em tirar dúvidas e fazer correções dos movimentos. Foi possível compreender que inúmeros outros fatores influenciaram no resultado da pesquisa proposta inicialmente.

Deve-se reconhecer que a limitação no domínio e no acesso a tecnologias de informação e comunicação, além da sobrecarga dos trabalhos sobrepostos no espaço do lar, podem ser os principais responsáveis por ter tornado a proposta das aulas online, para seguimento das oficinas, pouco atrativas, e até mesmo inviáveis para pessoas que já não tinham o hábito de realizar atividades físicas mesmo na modalidade presencial.

Foi compreendido que a educação em saúde é um processo político pedagógico o qual requer um trajeto de um pensar crítico reflexivo; ela nos permite diligenciar uma realidade e propor ações que a transformam, elevam o indivíduo à independência enquanto sujeito histórico-social que seja capaz de criar e opinar nas decisões de saúde para cuidar de si, de sua família e de sua coletividade. A formação do vínculo através da presença no espaço da escola pelos pesquisadores talvez resultasse de maneira mais positiva, devido a melhor organização do horário para atividade, reduzindo interferências externa, adaptando coletivamente a grade curricular para usufruir de um tempo para si, promovendo melhor interação para todos, valorizando o cuidado à saúde, fortalecendo vínculos da equipe.

A experiência foi transformadora para todos quando foi percebido que seriam necessárias adaptações para conclusão do processo iniciado e que mesmo com as adaptações o resultado não foi plenamente alcançado. No entanto, se houvesse possibilidade de seguimento deste estudo viabilizando encontros presenciais, poderia- se obter respostas mais efetivas em relação ao estudo sobre ensino e aprendizado do Lian Gong entre os professores da Escola Municipal Juca Leão. 


\section{REFERÊNCIAS}

[1]. ASSUNÇÃO, A.A; ABREU M.N.S. Pressão laboral, saúde e condições de trabalho dos professores da Educação Básica no Brasil. Cadernos de Saúde Pública. V.35, Sup.1:e001695172019.

[2]. BOBBO.V.C.D.et al. Saúde, dor e atividades de vida diária entre idosos praticantes de Lian Gong e sedentários. Ciência e Saúde Coletiva. V.23, n.4, 2018.

[3]. BURGOS, M. Escola pública e segmentos populares em um contexto de construção institucional da democracia. Dados. V. 55, n. 4, p. 1015-1054, 2012.

[4]. FREIRE, Paulo. Pedagogia da autonomia. Saberes necessários à prática educativa. Editora Paz e terra, 1996

[5]. GASPARINI. S.M.et al.o professor, as condições de trabalho e os efeitos sobre sua saúde. Educação e Pesquisa. V. 31, n. 2, p. 189-199, maio/ago 2005.

[6]. LEMOS, ANA HELOÍSA DA COSTA; BARBOSA, ALANE DE OLIVEIRA; MONZATO, PRISCILA PINHEIRO.

Mulheres em home office durante a pandemia da covid-19 e as configurações do conflito trabalho-família. Revista Administração de Empresas.V. 60, n. 6, p. 388-399, 2020.

[7]. LIVRAMENTO.G.et al. A ginástica terapêutica e preventiva chinesa Lian Gong /Qi Gong como um dos instrumentos na prevenção e reabilitação da LER/DORT. Revista Brasileira de Saúde Ocupacional. V. 35, n. 121, jun. 2010.

[8]. MARQUES.E.S.A.et al. Prática educativa bem-sucedida na escola: reflexões com base em L. S. Vigotski e Baruch de Espinosa. Revista Brasileira de Educação v. 22 n. 71, 2017 e227169

[9]. MARTINS. A.M. Mediação de conflitos em escolas: entre normas e percepções docentes. Cadernos de Pesquisa. V.46, n.161, p.566-592, jul./set. 2016.

[10]. ZANELLI, J. C.; KANAN, L. A. Fatores de risco, proteção psicossocial e trabalho: Organizações que emancipam ou que matam. Florianópolis: Uniplac. 2018. 


\section{Capítulo 10}

A voz profissional em tempo de Covid -19: Uma experiência fonoaudiológica para professores da Rede Municipal de Campos dos Goytacazes

Ilma Alessandra Lima Cabral Rodrigues

Isabela Dutra Coelho Brandt

Elizabeth Matilda Oliveira Williams

Tânia Machado de Carvalho

Resumo: A rotina do professor exige um grande esforço vocal e comumente percebemos profissionais que manifestam diversos problemas na voz. Isso ocorre, pois poucos docentes possuem preparo vocal para o uso profissional além de possuírem conhecimento superficial sobre cuidados vocais. Este trabalho teve como objetivo desenvolver uma proposta de informação vocal que pudesse atingir a um número elevado de professores da rede pública municipal da cidade de Campos dos Goytacazes, no formato de teleoficinas e aproximar a formação profissional dos acadêmicos de fonoaudiologia ao desenvolvimento de pesquisas. Foi desenvolvida uma pesquisa qualitativa baseada em um relato de caso, sendo a teleoficina a ferramenta utilizada pelas fonoaudiólogas do PSE (Programa Saúde na Escola) para alcançar o público-alvo de professores. Os resultados obtidos através das teleoficinas demonstraram que os participantes reconheceram a importância dos assuntos abordados e consideraram extremamente relevantes para a sua prática profissional. Desta forma, através do trabalho desenvolvido, foi possível identificar a importância da introdução de ações voltadas à saúde do professor com o intuito de amenizar os efeitos do trabalho sobre sua saúde assim como destacar a importância da inserção do fonoaudiólogo na atenção primária à saúde, a fim de facilitar estas ações na prática cotidiana.

Palavras-chave: Relato de caso, Saúde Vocal, Professor, Educação em Saúde; COVID-19. 


\section{INTRODUÇ̃̃OO}

Segundo o Ministério da Saúde (Brasil) (2009), a Atenção Primária à Saúde (APS) configura o primeiro contato na rede assistencial dentro do sistema de saúde, caracterizando-se, principalmente, pela continuidade e integralidade da atenção, além da coordenação da assistência dentro do próprio sistema, da atenção centrada na família, da orientação e participação comunitária e da competência cultural dos profissionais. Os atributos essenciais que devem ser estipulados são: o acesso de primeiro contato do indivíduo com o sistema de saúde, a continuidade e a integralidade da atenção, e a coordenação da atenção dentro do sistema (XAVIER, SANTOS E SILVA, 2013).

A Revista Saúde Pública (2002) afirma que um importante equipamento social em que a equipe de saúde atua são as escolas. Xavier, Santos e Silva (2013) destacam que as políticas de saúde reconhecem o espaço escolar como privilegiado para práticas promotoras da saúde preventivas e de educação para saúde, cujos processos educativos têm como eixos a construção de vidas mais saudáveis e a criação de ambientes favoráveis à saúde. Entretanto, há poucas ações dirigidas à saúde e vida do professor, que tem sido visto principalmente como um mediador, ou parceiro, nas ações desenvolvidas para promover a saúde destes mesmos (VALADÃO, 2004).

Para Behlau, Dragone e Nagano (2004), a docência exige grande demanda da voz e diversos problemas vocais são percebidos entre os professores. Poucos docentes possuem preparo vocal para o uso profissional e existe somente um conhecimento superficial a respeito dos cuidados com a voz assim como, falta atenção para as queixas, sinais e sintomas do processo saúde/doença vocal, como também às dificuldades em perceber, interpretar e enfrentar os determinantes de tal processo. 0 uso da voz se dá em condições laborais ambientais e organizacionais adversas e percebe-se a demora e a resistência na busca pelo atendimento especializado, o que faz do professor um profissional de risco para desenvolver um problema relacionado à voz (ALMEIDA, 2014).

De acordo com a Carta de Ottawa (1986), a saúde é resultante da ação de fatores políticos, econômicos, ambientais, comportamentais e biológicos. Com isso, torna-se de extrema importância a intervenção junto a esses profissionais, buscando promover a prevenção e a promoção da saúde vocal do professor, através de ações educativas que considerem o professor em suas reais condições de trabalho, estruturadas de modo a transformar os hábitos e aprimorar os mecanismos de produção vocal, enfatizando mudanças nas condições de vida e trabalho.

Bicudo-Pereira et al. (2003), a voz do professor é apontada por ele mesmo como um de seus principais recursos de trabalho, porém a responsabilidade de transmitir conhecimento, de formar culturalmente alunos e de cumprir os currículos escolares, entretanto leva muitas vezes o professor a relegar seus problemas vocais a segundo plano, buscando ajuda somente quando se torna impossível produzir uma voz audível. Além disso, como destacado por Alves, Oliveira e Behlau (2010) os professores vivem ainda dificuldades relacionadas à estressante jornada que precisam enfrentar, cerca de $90 \%$ dos docentes, cumprem, pelo menos, duas jornadas de trabalho, o que gera consequências diretas à sua qualidade vocal.

Almeida (2014), destaca a importância da voz na comunicação humana, na medida em que identificamos nela um meio eficiente para expressarmos nossos sentimentos, opiniões, vontades e idéias, denunciando nosso estado físico e emocional, assim como quando compreendemos e, até mesmo, idealizamos o outro através de sua voz. Assim, a voz nos traz o valor que cada palavra nem sempre carrega por si só, enriquecendo e "dando vida" à mensagem verbal (CRONEMBERGER, 2005).

Este fato toma outra dimensão quando nos referimos àquelas pessoas que utilizam a voz como principal instrumento de trabalho - os profissionais da voz - onde encontramos advogados, juízes, locutores, cantores, atores, ambulantes, políticos, líderes religiosos e professores, sendo esse último grupo o objeto desse relato (ALMEIDA, 2014).

Os professores possuem uma demanda e dinâmica fonoarticulatórias peculiares, pois lidam comumente com ambientes acusticamente inadequados, além de uma carga de trabalho exaustiva, com recursos pedagógicos deficientes, somados a um alto grau de estresse o que representa riscos para a saúde vocal dessa parcela significativa dos profissionais da voz. Assim, observa-se um grande índice de surgimento de distúrbios vocais relacionados ao trabalho (BRASIL, 2018).

É importante salientar que é preciso ir além das ações curativas individuais localizando os problemas de saúde na esfera coletiva, desenvolvendo ações preventivas, promoção e vigilância em saúde do trabalhador (LEFREVE E LEFREVE, 2004). Ortiz, Lima e Costa (2004), apontam que o fato do professor estar exposto a fatores de risco ocupacionais é da competência de todos profissionais que se dedicam a zelar pela saúde dos trabalhadores. Acredita-se que a saúde vocal dos professores não consiste apenas na 
ausência de alterações vocais, mas sim e principalmente, no bem-estar geral destes indivíduos, na qualidade de vida e de condições favoráveis para o desempenho de suas funções (XAVIER, SANTOS E SILVA, 2013).

Dragone et al. (2010) cita que uma das abordagens iniciais importantes para a intervenção fonoaudiológica refere-se à sensibilização para o verdadeiro significado da voz no ensino, proporcionando ao professor uma reflexão sobre o seu papel e os impactos deste instrumento de trabalho sobre a aprendizagem do aluno e, além disso, o aumento da percepção das queixas e sintomas vocais.

Diante de todo este contexto justificou-se a importância de ações preventivas junto aos professores buscando a promoção da saúde vocal, além de conscientização sobre a importância do auto cuidado, evitando assim que situações de trabalho alterem sua saúde e propiciem o melhor exercício de suas competências, alcançando os objetivos educacionais e qualidade de vida.

O objetivo geral deste trabalho foi relatar a experiência obtida através das orientações vocais e como objetivos específicos tivemos: considerar a necessidade de desenvolver uma proposta de informação vocal que pudesse atingir a um número elevado de professores devido a impossibilidade da realização de atividades presenciais pela pandemia do COVID-19, no formato de teleoficinas e aproximar a formação profissional dos acadêmicos de fonoaudiologia ao desenvolvimento de pesquisas.

\section{MATERIAIS E MÉTODOS}

Tivemos como metodologia um relato de caso, respeitando as determinações da legislação vigente, no que se refere aos protocolos sanitários de enfrentamento da pandemia da covid-19. A teleoficina foi a ferramenta utilizada pelas fonoaudiólogas do PSE (Programa Saúde na Escola) para alcançar o públicoalvo de professores. Assim, foram utilizadas as redes sociais para a divulgação do evento, assim como a inscrição que foi disponibilizada, através de formulário Google Forms, onde constaram as seguintes questões: Endereço de e-mail, nome completo, idade, área de atuação (Educação Infantil, Ensino Fundamental, E.J.A., outros), carga horária de trabalho, outra atividade envolvendo o uso profissional da voz, uso de algum recurso para cuidar da voz, presença de algum sintoma vocal, motivo de sua participação, opção do horário para a teleoficina. 0 objetivo do formulário, além da formalização da inscrição, foi obter informações sobre o conhecimento de aspectos relacionados à saúde vocal que pudessem nortear a construção da teleoficina.

No decorrer das inscrições, a participação foi ampliada aos profissionais da rede particular de ensino do município. No total, trezentos profissionais inscreveram-se nos eventos. Foram disponibilizadas nove opções de horário, durante três semanas consecutivas, ao longo do mês de março. Cada participante pôde participar de um encontro com uma hora de duração, onde recebeu informações sobre a fisiologia vocal e orientações sobre autocuidado, desmistificando algumas questões relacionadas à saúde vocal. Pelo chat do aplicativo de reunião e pelo e-mail, os professores manifestaram a impressão que tiveram do encontro, solicitando inclusive, novos encontros e material impresso sobre o assunto.

A ação contou com a participação dos acadêmicos do 8o período do curso de Fonoaudiologia do UNIFLU que, sob a supervisão das fonoaudiólogas do PSE e da professora da disciplina de Saúde Coletiva, elaboraram o material expositivo em PowerPoint e realizaram a dinâmica de apresentação para os participantes.

O Centro Universitário Fluminense abraçou a proposta por entender que entre outras contribuições ela poderia influenciar a criação de políticas de saúde no campo da saúde do professor, e em especial ao uso da voz, e fazer formação de estudantes da graduação para o desenvolvimento de programas de saúde tendo como base da ação intersetorial a noção de território. A opção pela temática ocorreu através da proposta desafiadora de atividade da disciplina Estágio Supervisionado em Saúde Coletiva, no qual os acadêmicos possuem acesso a uma área do conhecimento vinculada à prática profissional e política, comprometida com o coletivo.

É notória a importância em sensibilizar o professor quanto às questões vocais. 0 desconhecimento sobre noções básicas do próprio aparelho fonador ou de estratégias que possam melhorar a qualidade vocal sem causar danos ou prejuízos contribuem para o surgimento de queixas relacionadas ao distúrbio de voz, por parte dos docentes. Por isso, se faz necessário ações de saúde junto a este público, buscando a promoção da saúde através de práticas educativas e os fonoaudiólogos têm desenvolvido inúmeros trabalhos nesse sentido. 
As teleoficinas tiveram como referencial a iniciativa de Escolas Promotoras de Saúde, proposta em 1995 pela Organização Pan-Americana da Saúde (OPAS) com o objetivo de contribuir para ações que visem ao desenvolvimento humano saudável e à promoção de atitudes positivas para a saúde. Neste sentido, o foco principal foi a busca pela mudança no estilo de vida envolvendo os professores no processo de transformação através da conscientização sobre os cuidados e medidas importantes.

A Carta de Ottawa (1986), considera promoção da saúde como "o processo de capacitação da comunidade para atuar na melhoria da sua qualidade de vida e saúde, incluindo uma maior participação no controle deste processo". Recomenda cinco campos de ação: a elaboração e implementação de políticas públicas saudáveis; a criação de ambientes favoráveis à saúde; o reforço da ação comunitária; o desenvolvimento de habilidades pessoais; e a reorientação do sistema de saúde. Com base nesses princípios, as teleoficinas foram ministradas, ampliando sua abrangência por meio do Ensino à Distância, que no caso, foi realizada na Plataforma Google Meet.

O conteúdo abordado durante as teleoficinas foi dividido, de forma didática, em quatro seções: noções sobre a fisiologia da voz falada; contexto das demandas específicas para o uso profissional da voz do professor (ambiente físico e online); orientações práticas sobre o auto cuidado com a voz; quizz sobre mitos e verdades relacionadas à saúde vocal. Os professores tiveram oportunidade de expor suas dúvidas e crenças sobre o tema e, de forma geral, mostraram-se surpresos sobre as informações transmitidas.

\section{REFERENCIAL TEÓRICO}

A voz do professor é objeto de estudo entre inúmeros pesquisadores fonoaudiólogos devido à alta prevalência de distúrbio de voz nessa categoria profissional. Todos os estudos têm chegado à conclusão de que os riscos para tais trabalhadores desenvolverem alterações no trato vocal de ordem ocupacional é significativamente alto. Smith et al. (1998), relata que devido a uma demanda vocal intensa, o professor é considerado um profissional em frequente risco para desenvolver distúrbio de voz. Além disso, muitas vezes estes profissionais estão expostos a ambientes e condições de trabalho desfavoráveis.

Outros agravantes e fatores de risco comuns no processo laboral do professor favorecem o aparecimento de distúrbios vocais tais como mudanças bruscas no tom de voz, ausência de descanso vocal, competição com o ruído do ambiente, alimentação e posturas inadequadas, tensão da musculatura cervical, jornadas de trabalho extensa, além do enfrentamento de situações de angústia, ansiedade e estresse relacionado a cargos e funções. Segundo Jardim, Barreto e Assunção (2007), os distúrbios vocais podem ser determinados ou agravados por fatores que favorecem a sua ocorrência e podem ser externos, organizacionais, ambientais ou comportamentais do indivíduo, e a sobrecarga pode ser um desses fatores.

Leite e Siqueira (2017) consideram pertinentes e relevantes o desenvolvimento de atividades preventivas e de aprimoramento vocal com professores a fim de prevenir problemas futuros e aperfeiçoar sua comunicação permitindo a melhora de sua atuação. Percebe-se que a preservação da voz não é uma necessidade reconhecida pela maioria dos professores e muitos desses profissionais demonstram dificuldades em notar os sinais e os sintomas característicos de alterações vocais que apresentam. Para Simões e Latorre (2006), a falta de percepção dos problemas vocais entre professores, é um fator muito constante, além da aceitação passiva da alteração vocal, pois muitos acreditam ser esta uma consequência natural de sua profissão.

\section{RESULTADOS}

Todos os participantes ao finalizarem as Teleoficinas tiveram a oportunidade de expressar a sua avaliação através do Chat da Plataforma utilizada. De uma forma geral, os participantes disseram que o curso abordou assuntos de seu interesse e acharam que esse aprendizado foi importante para sua prática profissional. Confirmaram a possibilidade de refletir sobre o que aprenderam, mostrando um resultado positivo referente ao conteúdo exposto, pois o objetivo principal da ação era sensibilizar os professores quanto a importância do auto cuidado sob os aspectos vocais. Tais comentários evidenciaram que houve um retorno positivo nesse sentido.

Ao final dessa prática, o grupo de trabalho reconheceu a boa receptividade da proposta. Entretanto, o número atendido foi pouco expressivo se comparado a quantidade de educadores atuante na rede de ensino no município, bem como o número expressivo de afastamentos devido as alterações vocais. Nesse sentido, para os próximos encontros pretende-se oferecer outros horários e datas visando atingir o público que possivelmente esteve impossibilitado em participar. Contudo, a experiência mostrou-se 
positiva tanto no que se refere ao público-alvo (professores) como na formação dos profissionais (estudantes de graduação na área da Fonoaudiologia) que participaram da proposta.

\section{DISCUSSÃO}

Jardim, Barreto, Assunção (2007), cita que a população pesquisada é considerada como população de risco para alterações vocais, apresentando várias queixas relacionadas ao mau uso da voz, o que serve de alerta para que busquem maiores cuidados com a voz, que pode dar sinais auditivos de estar sofrendo alguma alteração merecedora de atenção sendo, portanto, é importante estar atento a estes sinais.

A voz do professor é um assunto bastante discutido. Sabe-se que os distúrbios vocais em professores têm alta prevalência se comparado com a população de forma geral, sendo a voz o principal meio de comunicação e uma importante ferramenta pedagógica e, portanto, necessita estar saudável e produzida sem esforço.

É importante destacar que as Teleoficinas têm como foco a conscientização do professor quanto às condições em que sua voz é produzida, a auto avaliação, além de cuidados básicos quanto ao uso da voz como ferramenta de trabalho e, em nenhum momento, foi apresentada a possibilidade de se realizar nenhum tipo de tratamento à distância.

Apesar da avaliação positiva das oficinas, algumas professoras pensaram em desistir da participação por falta de tempo e por vergonha de realizar as atividades em grupo, uma delas referiu ainda, dificuldade em realizar alguns exercícios orientados.

Ceballos et al. (2001), diz que o tempo do professor é escasso, a maioria trabalha em mais de uma escola e ainda tem família e filhos, entretanto, a maioria das participantes deste estudo relatou que estava realizando os exercícios sugeridos nas oficinas. 0 relato de uma das professoras sugere até mesmo a necessidade de trabalho do fonoaudiólogo na escola.

Tendo em vista que as questões de saúde do professor ultrapassam os problemas com a voz, ressalta-se a inclusão de equipes multiprofissionais nas escolas e recomenda-se que o PSE seja voltado não apenas para o escolar, mas para a escola, contribuindo com ações voltadas para a comunidade escolar, incluindo pais, professores e demais profissionais, além dos alunos; bem como para que o ambiente de trabalho seja mais saudável.

\section{CONCLUSÃO}

A proposta das Teleoficinas sobre Saúde Vocal do Professor mostrou-se desafiadora por ser uma intervenção na perspectiva da promoção da saúde realizada durante um momento tão conturbado onde toda população mundial se vê diante da pandemia do novo coronavírus e todas as atenções estão voltadas para um cenário de incertezas e inseguranças.

Como uma das principais medidas para conter o avanço do novo coronavírus foi a suspensão de aulas presenciais em escolas e universidades, os professores e alunos tiveram que se adaptar a rotina da utilização do meio virtual e ainda nos dias atuais enfrentam diversos desafios. Embora afastados das salas de aulas presenciais, as atividades remotas expõem os professores a condições ainda mais desafiadoras e o desempenho vocal acaba sofrendo consequências negativas. Muitos relatos de cansaço extremo em aulas remotas confirmam a necessidade de orientações a respeito da saúde vocal do professor, sobretudo em situações adversas onde a voz se torna um instrumento único, considerando o fato de que as aulas presenciais possibilitam uma comunicação através de outras estratégias.

Destacou-se que a falta de conhecimento sobre os cuidados com a saúde vocal durante o desempenho das funções laborais, bem como sobre a importância da realização de exercícios de aquecimento e desaquecimento, ainda se faz presente no meio dos educadores.

Concluiu-se então que, a experiência se mostrou positiva tanto no que se refere ao público-alvo (professores) como na formação dos profissionais (estudantes de graduação na área da Fonoaudiologia) que participaram da proposta. 


\section{REFERÊNCIAS}

[1] ALMEIDA, Raíssa Praes. 0 professor e sua voz: aspectos relacionados à saúde vocal e ao aparecimento de disfonias. Monografia apresentada à Universidade Federal de Minas Gerais. Corinto, 2014.

[2] ALVES, Liliana Amorim; OLIVEIRA, Gisele.; BEHLAU, Mara. A Voz das Professoras Durante a Atividade Letiva. Revista Baiana de Saúde Pública, v.34, n.4, p.865-878 out./dez. 2010.

[3] BEHLAU, Mara; DRAGONE, Maria Lúcia Suzigan; NAGANO, Lúcia. A voz que ensina: o professor e a comunicação oral em sala de aula. Rio de Janeiro: Revinter; 2004.

[4] BICUDO-PEREIRA, Isabel Maria Teixeira; PENTEADO, Regina Zanella; BYDLOWSKI, Cynthia Rachid; ELMOR, Maísa Rose Domênico; GRAZIELLI, Maria Elisabete. Escolas Promotoras de Saúde: onde está o trabalhador professor? Saúde em revista, 2003.

[5] BRASIL. Fundação Nacional de Saúde. Diretrizes de educação em saúde visando à promoção da saúde: documento base - documento I/Fundação Nacional de Saúde - Brasília: Funasa, 2007.

[6] BRASIL. Ministério da Saúde. Secretaria de Políticas de Saúde. Projeto Promoção da Saúde. As cartas de promoção da saúde. Brasília: Ministério da Saúde; 2002.

[7] BRASIL. Ministério da Saúde. Secretaria de Atenção à Saúde, Departamento de Atenção Básica, Informe de Atenção Básica, n. 55. 0 Programa de Saúde na Escola. Brasília: Ministério da Saúde; 2009.

[8] BRASIL. Ministério da Saúde. Secretaria de Vigilância em Saúde. Departamento de Vigilância em Saúde Ambiental e Saúde do Trabalhador. Distúrbios de Voz relacionados ao trabalho - DVRT. Brasília, Ministério da Saúde, 2018.

[9] CONFERÊNCIA INTERNACIONAL SOBRE PROMOÇÃO DA SAÚDE, 1986, Ottawa. Carta de Otawa. In: BRASIL. Ministério da Saúde.

[10] CEBALLOS, Albanita Gomes da Costa; CARVALHO, Fernando Martins; ARAÚJO, Tânia Maria; REIS, Eduardo José Farias Borges. Avaliação percepto-auditiva e fatores associados à alteração vocal em professores. Rev. Bras Epidemiologia; 14(2): 285-95, 2001.

[11] CRONEMBERGER, Flávia Fialho. A voz do professor nas práticas discursivas em sala de aula. Dissertação apresentada ao Programa de Pós Graduação em Educação e Contemporaneidade da Universidade do Estado da Bahia. Salvador, 2005.

[12] DRAGONE, Maria Lúcia Suzigan; FERREIRA, Leslie Piccolotto; GIANNINI, Susana Pimentel Pinto; SIMÕESZENARI, Márcia; VIEIRA, Vanessa Pedrosa; BEHLAU, Mara. Voz do professor: uma revisão de 15 anos de contribuição fonoaudiológica. Revista da Sociedade Brasileira de Fonoaudiologia. [Internet]. 2010

[13] HEIDMANN, Ivonete T.S; ALMEIDA, Maria Cecília Puntel; BOEHS, Astrid Eggert; WOSNY, Antônio Miranda; MONTICELLI, Marisa. Promoção à saúde: trajetória histórica de suas concepções. Enfermagem. 15(2):352-8; 2006.

[14] JARDIM, Renata; BARRETO, Sandhi Maria; ASSUNÇÃO, Ada Ávila. Condições de trabalho, qualidade de vida e disfonia entre docentes. Cadernos de Saúde Pública; 23(10): 2439-61, 2007.

[15] JARDIM, Renata; BARRETO, Sandhi Maria; ASSUNÇÃO, Ada Ávila. Disfonia: definição de caso e prevalência em professores. Revista Brasileira de Epidemiologia. [Internet]. 2007

[16] LEFEVRE, Fernando; LEFEVRE, Ana Maria Cavalcanti. Promoção de Saúde: a negação da negação. Editora Vieira e Lent. Rio de Janeiro, 2004.

[17] LEITE, A.P.D.; SIQUEIRA, L.T.D. Aprimoramento da Voz e da comunicação do professor universitário - a importância da saúde da voz, da postura e comunicação em sala de aula. 35은 SEURS. 2017.

[18] PROJETO PROMOÇÃo DA SAÚDE. Secretaria de Políticas de Saúde/MS. A promoção da saúde no contexto escolar. Revista de Saúde Pública; 36 (2):533-5. 2002.

[19] ORTIZ, Erica; LIMA, Elieuza Aparecida; COSTA, Everardo. Saúde vocal de professores da rede municipal de ensino de cidade do interior de São Paulo. Revista Brasileira de Medicina do Trabalho; 2 (4):263-6. 2004.

[20] SIMÕES, Márcia; LATORRE, Maria do Rosário Dias de Oliveira. Prevalência de alteração vocal em educadoras e sua relação com a auto percepção. Revista de Saúde Pública. 2006

[21] SMITH, Elaine; LEMKE, Jon; TAYLOR, Margaretta; KIRCHNER, Lester; HOFFMAN, Henry. Frequency of voice problems among teachers and other occupations. Journal of Voice. Dec; 12(4):480-8; 1998.

[22] VALADÃO, Marina Marcos. Saúde na escola: um campo em busca de espaço na agenda intersetorial. Tese apresentada ao Departamento de Prática de Saúde Pública da Universidade de São Paulo. São Paulo, 2004.

[23] XAVIER, Ivana Arrais de Lavor; SANTOS, Ana Célia de Oliveira; SILVA, Danielle Maria. Saúde vocal do professor: intervenção fonoaudiológica na atenção primária à saúde. Revista CEFAC, jul-ago; 15(4):976-985, 2013. 


\title{
Capítulo 11
}

\section{Síndrome inflamatória multissistêmica após infecção por COVID-19 em crianças: Uma revisão integrativa da literatura}

\author{
Marina Gontijo Tuyama \\ Amanda Schmitberger Pelisson \\ Ana Clara Camargo Rocha \\ Isabelle Faria Safadi \\ Laura Andrade Almeida \\ Luisa Andrade de Almeida \\ Rafaela Valadares Zucconi \\ Silvia Andrade Lopes \\ Taina Wendling Gama
}

Resumo: Objetivo: Elucidar, por meio de uma uma revisão integrativa de artigos atuais, conhecimentos a respeito da síndrome inflamatória multissistêmica após infecção por covid-19 em pacientes pediátricos (SIM-P). Métodos: Foi realizada revisão bibliográfica nos idiomas inglês e português por meio dos descritores: Infecções por coronavírus, criança, síndrome inflamatória multissistêmica. Foram selecionados estudos publicados de 2020 a 2021, nas bases de dados Lilacs, Scielo, Scopus, MEDLINE, Acervo +, Pubmed, Ministério da Saúde e DOAJ. Revisão Bibliográfica: A Síndrome inflamatória multissistêmica (SIM-P) é uma patologia caracterizada pelo acometimento de vários sistemas corporais, como circulatório, nervoso, muscular, tegumentar, imunológico, respiratório, entre outros, após duas a três semanas da infecção pelo SARS-CoV-2. Até Abril de 2020 as crianças acometidas com a COVID-19 não apresentavam muitas complicações ou reações durante a infecção pelo vírus. Entretanto, nesse período o Reino Unido relatou 8 casos de crianças que algumas semanas após a infecção pelo SARCOV-2 ou após contato com algum indivíduo com a doença, passaram a apresentar sintomas que se relacionavam com a Doença de Kawassaki, o que passou a preocupar vários médicos. Desde então, essa condição adversa veem sendo estudada e aprofundada com o intuito de orientar os médicos em relação ao tratamento e manejo desses pacientes. Conclusão: Embora ainda pouco se saiba sobre a fisiopatologia da SIM-P, as informações disponíveis são suficientes para alertar o médico sobre a potencial gravidade da doença e a necessidade de estar alerta para identificar e investigar precocemente os casos suspeitos e monitorar as complicações através de vigilância contínua. Observa-se, também, que as consequências da infecção causada pelo vírus SARCOV-2 ainda é não é muito conhecida pelos médicos e estudiosos, e a cada dia descobrimos um pouco mais sobre essa nova infecção. Por isso torna-se extremamente importante a busca por informações, casos clínicos e revisões bibliográficas que nos ajudem a aprimorar o manejo desses pacientes.

Palavras-chave: Infecções por coronavírus, criança, síndrome inflamatória multissistêmica. 


\section{INTRODUÇÃO}

Até o momento, as crianças respondem por uma porção mínima dos casos na pandemia global da COVID19 e dados epidemiológicos de vários países mostram que elas usualmente evoluem de forma oligossintomática, com baixa taxa de complicações. Entretanto, uma doença grave, embora pouco frequente, foi temporalmente relacionada à infecção por COVID-19 em pacientes pediátricos, denominada como Síndrome inflamatória multissistêmica (SIM-P). Essa patologia é caracterizada pelo acometimento de vários sistemas corporais, como circulatório, nervoso, muscular, tegumentar, imunológico, respiratório, entre outros, após duas a três semanas da infecção pelo SARS-CoV-2. Estudos recentes afirmam que, em até $20 \%$ dos casos da SIM-P, ocorrem manifestações gastrointestinais, tais como vômitos, dor abdominal e diarreia; no entanto, acredita-se que esse valor esteja subestimado. (CASTRO.P, et al.,2009;). Uma das principais complicações associadas à síndrome é o choque, detectado através de hipotensão arterial, taquicardia e má perfusão, resultante tanto da disfunção miocárdica quanto da diminuição da resistência vascular periférica. Os sintomas respiratórios graves costumam ser menos frequentes e relevantes, geralmente secundários à descompensação hemodinâmica. Por ser uma patologia na qual é encontrada uma ampla variedade de sinais e sintomas sistêmicos, é facilmente confundida com outras condições inflamatórias pediátricas, tais como a doença de Kawasaki (DK), choques tóxico estafilocócico e estreptocócico e a síndrome de ativação macrofágica.

Os primeiros casos registrados de SIM-P no mundo foram em abril de 2020, no Reino Unido, Foram registrados 8 casos de crianças saudáveis que apresentaram choque cardiovascular, febre e hiperinflamação, após pesquisas surgiram os alertas iniciais sobre a identificação de uma resposta inflamatória sistêmica grave temporalmente associada aos casos de Covid-19 FELDSTEIN, L.R. et al. 2020). Desde então, multiplicaram-se relatos de quadros semelhantes na Europa, Ásia, Estados Unidos e em vários países da América Latina (LINHARES M, et al., 2020). A faixa etária dos pacientes afetados pela SIMP é, usualmente, mais elevada do que a encontrada nos pacientes com DK.(PACÍFICO, et al., 2020). A abordagem inicial para a detecção da doença envolve, além do nexo epidemiológico de infecção prévia por Covid-19, a realização das provas de atividade inflamatórias, hemograma, função renal e função hepática. Quando estes exames mostram-se sugestivos da suspeita inicial, deve-se completar a avaliação com a investigação de distúrbios de coagulação e exames para avaliar a possibilidade de comprometimento cardiovascular. Alguns sinais de alerta devem ser monitorados em crianças com SIM-P, como dor ou sensação persistente de pressão no peito, dispnéia, confusão mental, dificuldade de se manter acordado, palidez ou cianose e dor abdominal intensa. Nos casos que se apresentam similarmente com critérios diagnósticos de DK clássica, indica-se a terapia usual com imunoglobulina endovenosa (IVIG) e ácido acetilsalicílico (AAS). Atualmente há critérios mais objetivos para uso de imunoglobulina na SIM-P, mesmo sem suspeita de DK.

É de extrema importância ressaltar que a SIM-P apresenta complicações que podem evoluir com gravidade, sendo necessária, em alguns casos, a internação em UTI pediátrica e terapêutica que compreende administração de drogas vasoativas e anticoagulantes. Após a alta hospitalar, crianças e adolescentes com SIM-P deverão ser continuamente assistidas e acompanhadas pela atenção básica e, caso necessário, por especialistas, principalmente aquelas que apresentarem cardiopatias (aneurismas coronarianos e disfunções miocárdicas), pneumopatias, comprometimento renal, trombose e neuropatias.

\section{DESCRIÇÃO DOS MÉTODOS APLICADOS}

Revisão de literatura com levantamento de artigos nas bases indexadas Lilacs, Scielo, Scopus, MEDLINE, Acervo +, Pubmed, Ministério da Saúde e DOAJ. Valendo-se dos descritores "Síndrome inflamatória multissistêmica", "COVID-19" e " criança". Foram selecionados artigos de revisão e revisão sistemática, nas línguas inglesa e portuguesa, publicados em 2020 e 2021. Além disso, foram utilizados para a discussão textos técnicos de instituições cientificamente reconhecidas.

\section{DISCUSSÃO}

Durante o auge da pandemia do Covid-19, em abril de 2020, o Sistema Nacional de Saúde Inglês (NHS) alertou a respeito de uma nova síndrome em crianças, possivelmente relacionada ao Sars-CoV-2, a Síndrome Inflamatória Multissistêmica Pediátrica (SIM-P). Com o aumento significativo de casos mundialmente, o Ministério da Saúde brasileiro passou a exigir obrigatoriedade na notificação dessa doença (Notificação obrigatória no Ministério da Saúde dos casos de síndrome inflamatória multissistêmica pediátrica (SIM-P), et al. 2020). 


\section{- $\quad$ Epidemiologia}

Do dia $1^{\text {o }}$ de abril de 2020 a 13 de março de 2021, segundo o BOLETIM EPIDEMIOLÓGICO N 12 - 03/2021 do Ministério da Saúde, o Brasil registrou 813 casos confirmados da SIM-P temporalmente associada à covid-19. Os casos foram em crianças e adolescentes de 0 a 19 anos, sendo que destes, 51 evoluíram para óbito (letalidade de 6,3\%). Dos 51 óbitos ocorridos, 47,1\% $(\mathrm{n}=24)$ foram em crianças de 0 a 4 anos. Dos casos notificados, 623 (76,7\%) foram encerrados pelo critério laboratorial e 190 (23,3\%) pelo critério clínico-epidemiológico.

As faixas etárias predominantes em relação ao número de casos foram de 0 a 4 anos (41,9\%) e de 5 a 9 anos (34,3\%). Também notou-se uma predominancia de casos no sexo masculino, sendo 461 (56,7\%) dos casos pertencente a esse grupo.

Um estudo realizado em Goiás, no ano de 2020, com 14 pacientes com critérios para SIM-P, constatou as complicações clínicas mais frequentes: hipotensão (50,0\%), insuficiência renal aguda (35,7\%), e 21,4\% apresentaram septicemias, pneumonia e edema agudo de pulmão. Apenas 21,4\% dos pacientes acometidos pela síndrome não apresentaram complicações. A ventilação não invasiva foi necessária em $28,6 \%$ dos casos. Além disso, o estudo ressalta a importância da realização rotineira de ecocardiograma nos pacientes com SIM-P, uma vez que 38,8\% dos casos apresentaram sinais de valvulite e disfunção miocárdica e 23,1\% tiveram sinais de pericardite (BOLETIM EPIDEMIOLÓGICO Nº 01 - 22/12/2020).

Estudo realizado pela USP em parceria com hospital pediátrico de referência mostrou, em análise inicial, dados de 93 pacientes menores de 10 anos, admitidos entre março e setembro de 2020 com síndrome gripal. Destes, 35\% apresentavam ao menos uma comorbidade, entre doença falciforme, asma, encefalopatia, nefropatia, alergia ao leite de vaca e prematuridade.

Apesar do estudo ainda não ter dados com significância estatística, Loggetto destacou que não foi observada uma relação entre as alterações no hemograma e os sinais de gravidade nas crianças acometidas pelo coronavírus. Outro ponto interessante é que, além de apresentar linfopenia, plaquetopenia, neutrofilia e eosinopenia como os adultos contaminados pela Covid-19, as crianças exibiram quadros de atipia linfocitária e monocitose, quadros que futuramente podem indicar complicações para a SIM-P. (SABARÁ HOSPITAL INFANTIL, 2020).

\section{- $\quad$ Fatores de risco}

Dentre os principais fatores de risco para o desenvolvimento da Síndrome inflamatória multissistêmica são destacados idade, carga viral e comorbidades associadas. A faixa etária na qual há maior incidência da SIM-P corresponde a indivíduos maiores de cinco anos de idade; entretanto, estudos recentes demonstram que crianças menores de um ano apresentam maior suscetibilidade à desenvolver a forma grave da doença. Outro dado que parece compor bases etiológicas dessa complicação é a predisposição genética. Alguns pesquisadores sugerem que um locus genético específico tem associação com a SIM-P, assim como alguns grupos étnicos, sendo destacada a população afrodescendente (TOUBIANA J. et al., 2020). Em relação à carga viral, além da lesão indireta por meio do estado hiper inflamatório conferido pela síndrome, também há lesão tecidual direta mediada pelo coronavírus. Dessa forma, quanto maior a carga viral maior será a lesão nos tecidos-alvo (LORIA MFB, 2020; DOLHNIKOFF M, et al., 2020). Um estudo americano que avaliou pacientes com SIM-P internados em UTIs nos Estados Unidos e no Canadá em 2020 demonstrou que $83 \%$ das crianças apresentavam comorbidades como doença cardíaca, atraso no desenvolvimento, diabetes, comprometimento imunológico, malignidade, obesidade, pós-transplante e traqueostomia. Desse modo, concluiu-se que a existência de condições médicas preexistentes foram determinantes para a manifestação de formas graves e sintomáticas da doença. ( SHEKERDEMIAN LS, et al., 2020). 


\section{- $\quad$ Fisiopatologia}

Mesmo com a vasta gama de estudos realizados acerca das complicações da Covid-19, a fisiopatologia da SIM-P permanece inconclusiva. O SARS-CoV-2, quando em contato com o novo hospedeiro, penetra nas células do coração, pulmão, alvéolos, vasos sanguíneos e nas células fagocíticas, acoplado aos receptores da enzima conversora de angiotensina 2, expressos por estes tecidos. Quando esse fenômeno ocorre, alguns indivíduos apresentam função imune prejudicada, com depressão na produção de complexos antivirais. Concomitantemente, há indução de resposta imune exacerbada com uma tempestade de citocinas, seguida por múltiplas lesões endoteliais e quadro inflamatório exacerbado. A hiperinflamação desencadeia lesões em órgãos-alvo, sendo responsável pelas manifestações da SIM-P (SARA) (VARGA Z, et al., 2020).

\section{- Diagnóstico}

De acordo com o Ministério da Saúde, a Organização Pan-Americana da Saúde (OPAS) e a Sociedade Brasileira de Pediatria (SBP), para realizar o diagnóstico de SIM-P o paciente deve apresentar pelo menos dois dos seguintes sintomas:

1. Conjuntivite não purulenta ou erupção cutânea bilateral ou sinais de inflamação mucocutânea (oral, mãos ou pés);

2. Hipotensão arterial ou choque;

3. Manifestações de disfunção miocárdica, pericardite, valvulite ou anormalidades coronárias (incluindo achados do ecocardiograma);

4. Evidência de coagulopatia (por alterações em coagulograma ou D-dímero elevado).

5. Manifestações gastrointestinais agudas (diarréia, vômito ou dor abdominal);

Além do quadro clínico sugestivo, o paciente deve apresentar também marcadores de inflamação elevados, como Velocidade de Hemossedimentação (VHS) e Proteína C Reativa (PCR) e a evidência de infecção prévia por Covid-19, confirmada laboratorialmente ou por vínculo epidemiológico (LORIA MFB, 2020)

Caso os exames apontem para a maior probabilidade da síndrome inflamatória multissistêmica, é necessário completar a avaliação propedêutica com dosagem de desidrogenase lática (LDH), triglicerídeos, ferritina, creatinoquinase (CK), e marcadores da função miocárdica, além de investigar possíveis distúrbios de coagulação. Exames como o eletrocardiograma, ecocardiograma, radiografia de tórax e abdome, e ultrassonografia, contribuem para que seja determinada a extensão dos efeitos gerados por essa patologia (MOURA SK. et al., 2020).

Essa rara síndrome que acomete crianças compartilha características comuns com outras condições inflamatórias pediátricas, incluindo a doença de Kawasaki, podendo gerar erro ao diagnóstico (Tabela 1.1). 
Tabela 1.1 - Comparação dos principais sintomas entre a Síndrome Inflamatória Multissistêmica (MIS-C) e a Doença de Kawasaki.

\begin{tabular}{|l|l|l|}
\multicolumn{2}{|c}{ Sintomas } & $\begin{array}{c}\text { Síndrome Inflamatória } \\
\text { Multissistêmica }\end{array}$ \\
\hline Febre & Febre alta persistente & Febre persistente - tempo médio de cinco dias \\
\hline Exantemas & Exantemas polimórfico & Exantema polimorfo \\
\hline Sintomas gastrointestinais & $\begin{array}{l}50-60 \% \text { dos casos apresenta } \\
\text { manifestações GI }\end{array}$ & $\begin{array}{l}\text { Estão presentes na DK como sintomas } \\
\text { inespecíficos associados. }\end{array}$ \\
\hline Linfadenopatia & Linfadenopatía generalizada & $\begin{array}{l}\text { Linfadenopatia cervical (pelo menos 1 nódulo } \geq \\
1,5 \text { cm de diâmetro) }\end{array}$ \\
\hline Conjuntivite & Conjuntivite não purulenta & Conjuntivite bilateral não exsudativa \\
\hline Alteração em cavidade oral & Mucosite oral & Alteração nos lábios; língua em framboesa. \\
\hline Alteração das extremidades & Edema nas extremidades & Eritema, edema. \\
\hline Cefaleia & Presença de Cefaleia & $\begin{array}{l}\text { Presença de cefaleia como um sintoma } \\
\text { inespecífico associado. }\end{array}$ \\
\hline Alterações cardíacas & $\begin{array}{l}\text { Disfunção miocárdica; aneurisma } \\
\text { de artérias coronárias; valvulite; } \\
\text { pericardite; taquicardia. }\end{array}$ & $\begin{array}{l}\text { Miocardite; pericardite; insuficiência mitral } \\
\text { aguda; dilatação/aneurisma de artéria } \\
\text { coronária. }\end{array}$ \\
\hline
\end{tabular}

Tabela 1.2 - Comparação do diagnóstico laboratorial entre a Síndrome Inflamatória Multissistêmica (MISC) e a Doença de Kawasaki.

\begin{tabular}{|l|l|l|} 
& \multicolumn{1}{c}{$\begin{array}{c}\text { Síndrome Inflamatória } \\
\text { Multissistêmica }\end{array}$} & \multicolumn{1}{c}{ Doença de Kawasaki } \\
\hline Diagnóstico Laboratorial & $\begin{array}{l}\text { Exame de RT-PCR, sorologia } \\
\text { IgG/IgM ou investigação da } \\
\text { presença do antígeno do Covid-19. } \\
\text { Os achados laboratoriais mais } \\
\text { característicos dessa patologia são } \\
\text { a hiperferritinemia, queda do } \\
\text { fibrinogênio, aumento de } \\
\text { transaminases, } \\
\text { hipertrigliceridemia, queda da } \\
\text { VHS e aumento da PCR. }\end{array}$ & $\begin{array}{l}\text { latretanto, existem achados laboratoriais } \\
\text { característicos, na fase aguda do quadro, o } \\
\text { hemograma pode mostrar anemia, leucocitose } \\
\text { com neutrofilia e com desvio para a esquerda e } \\
\text { trombocitose. Pode haver aumento do VHS e } \\
\text { PCR. A piúria estéril, discreta elevação das } \\
\text { transaminases hepáticas, hiperbilirrubinemia e } \\
\text { pleocitose do líquido cefalorraquidiano também } \\
\text { podem estar presentes. }\end{array}$ \\
\hline
\end{tabular}

\section{- Tratamento}

Apesar de ainda não existir um protocolo oficial para o tratamento da síndrome inflamatória multissistêmica, temos similaridades na conduta dos profissionais da saúde de diferentes instituições. A propedêutica para tratamento engloba a gravidade do quadro e o acometimento de órgãos-alvos, que levam a manifestações clínicas específicas (LORIA MFB, 2020). Nos casos leves de SIM-P, ou seja, situações em que o paciente esteja hemodinamicamente estável e com condições clínicas que não necessitam de intervenção imediata, é orientado o tratamento sintomático. Além disso, deve-se começar investigação laboratorial, através dos exames já citados anteriormente, para investigar a possibilidade de complicações ainda sem manifestações clínicas exuberantes possibilitando a detecção precoce de condições de maior risco para evolução desfavorável. Em pacientes com qualquer sinal vital alterado é indicado o suporte inicial com internação hospitalar, para investigação minuciosa principalmente do estado hemodinâmico. A internação é indicada para aqueles pacientes que, além de apresentarem pelo menos dois dos sintomas 
citados anteriormente também apresentem febre elevada (no mínimo de $38^{\circ} \mathrm{C}$ ) e persistente ( $\geq 3$ dias) na faixa etária entre 0 e 19 anos de idade. (LORIA MFB, 2020). Em relação ao uso de medicamentos, um estudo feito por MOURA, Adriana Ávila, et al., descreveu a indicação das principais classes utilizadas:

- Antimicrobianos: iniciado apenas nos casos que apresentam choque ou sepse, é suspenso após afastar infecção bacteriana mediante resultado do exame de cultura. Nesses casos a droga de escolha é o Ceftriaxone $(100 \mathrm{mg} / \mathrm{kg} / \mathrm{dia})$.

- Imunoglobulina endovenosa (IVIG) utilizada em pacientes com gravidade, choque, disfunção miocárdica moderada a grave e aneurisma de coronárias. Nesses casos deve ser feita a infusão endovenosa contínua, podendo ser repetida nos casos refratários 48 horas após a primeira dose.

- Anticoagulantes: essas drogas devem ser consideradas em pacientes que preenchem os critérios da síndrome de Kawasaki e nos casos moderados e graves de SIM-P (lesão de um ou mais órgãos, somado à necessidade de respirador). a.

- Corticosteroides: devem ser prescritos concomitantes à IVIG nos casos graves ou refratários à infusão da imunoglobulina. Alguns estudiosos afirmam que a utilização de baixas doses de dexametasona podem ser benéficas em reduzir a resposta imune e a inflamação dos pacientes acometidos com a síndrome (JIANG L, et al., 2020).

- Suporte inotrópico: medicamentos vasopressores como Dobutamina ou Milrinona são indicados no tratamento de pacientes com manifestações cardíacas, com sinais de baixo débito ou insuficiência cardíaca com pressão arterial sistêmica normal. Em indivíduos em quadro de hipotensão arterial sistêmica é preconizada a administração de Epinefrina.

- Imunomoduladores: avaliar em casos refratários ao tratamento preconizado com IVIG/ corticoides.

- Pulsoterapia: consiste na administração de altas doses de medicamento em um curto intervalo de tempo. É indicada apenas para os casos mais graves, e nesses casos a droga indicada é a metilprednisolona (30mg/kg/dia por 3 dias) deve-se prescrever uma dose de manutenção de $2 \mathrm{mg} / \mathrm{kg} /$ dia após o período de pulsoterapia. A utilização desse tratamento ainda é controversa, sendo necessária uma avaliação individualizada para cada paciente. (CAMPOS LR, et al., 2020).

- Reposição volêmica: administrar expansão volêmica vigorosa com cristalóides, preferencialmente Ringer Lactato. Em pacientes que apresentarem forma refratária à reposição volêmica, deve-se adicionar drogas vasoativas como adrenalina ou noradrenalina.

Além do tratamento medicamentoso também é indicado o tratamento comportamental. Podemos citar o isolamento social como uma medida importante no tratamento da SIM-P levando em consideração as manifestações clínicas e os resultados da pesquisa viral para SARS-CoV-2 (RT-PCR) É importante ressaltar que, como a fisiopatologia da SIM-P ainda não foi bem estabelecida, o tratamento ainda pode sofrer várias mudanças. 
Figura 1.0 - Conduta realizada no tratamento de MIS-C.

\section{Tratamento para MIIS-C} saúde em todo o mundo possuem condutas semelhantes, baseados no quadro clínico do paciente e gravidade do mesmo.

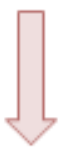

DK clássica -gamaglobulina endovenosa (IVIG) e ácido acetilsalicilico (AAS).

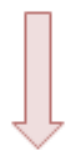

AAS na dose de 80 $100 \mathrm{mg} / \mathrm{kg} / \mathrm{dia}$, mudando para a dose de $3-5 \mathrm{mg} / \mathrm{kg} / \mathrm{dia}$ após o fim da febre.
DK incompleta -gamaglobulina endovenosa mesmo para os casos de MIS-C que não preenchem critérios para DK 
Figura 1.1 - Variação do tratamento para MIS-C em decorrência do grau (leve, moderado ou grave) que o paciente se encontra.

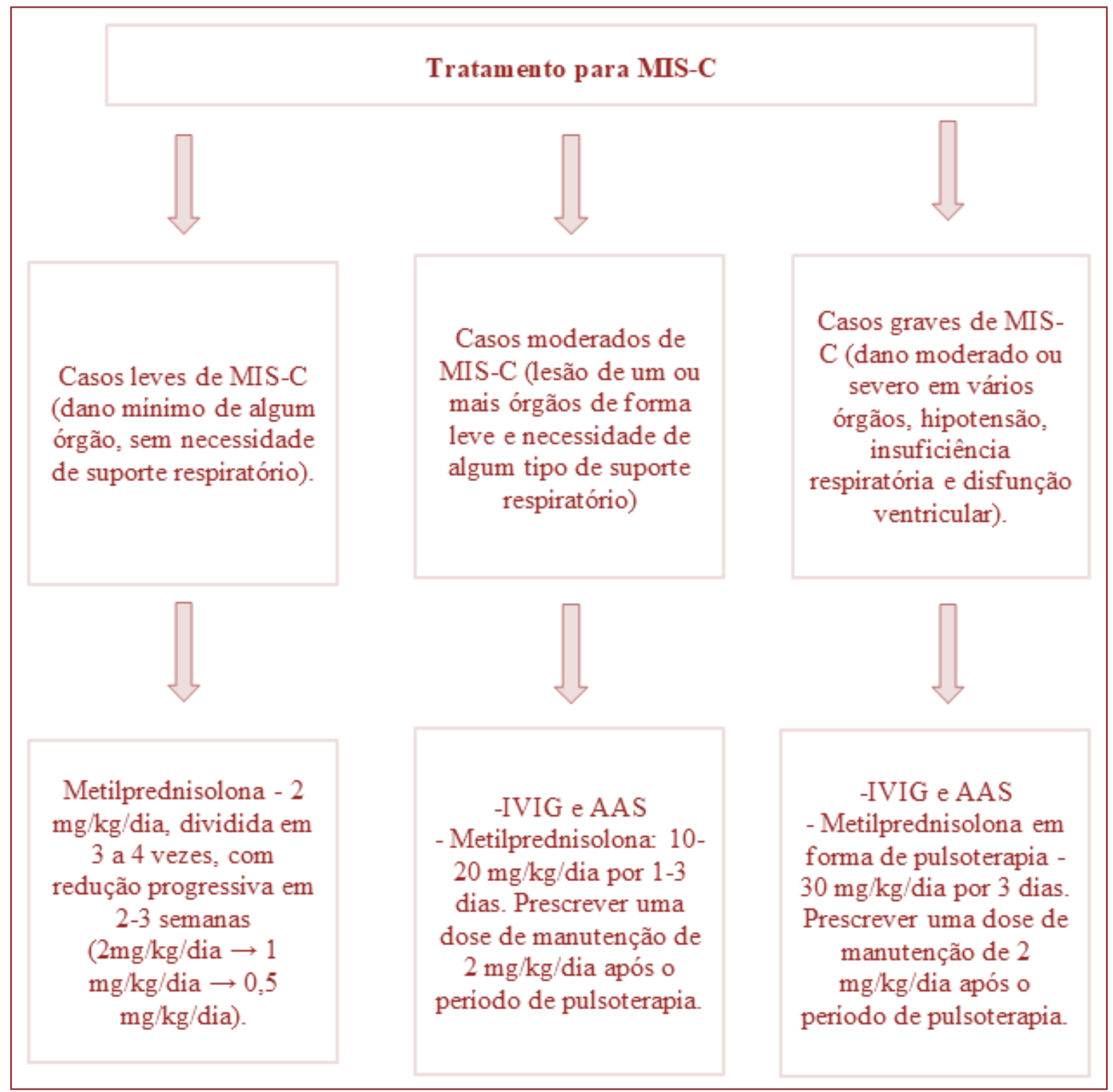

\section{RESULTADOS}

Inicialmente selecionamos 28 artigos. Em um primeiro momento, 3 deles foram descartados por não abordar a população pediátrica, restando então 25 artigos. Em seguida foram retirados outros 4 artigos devido ao fato de apenas citarem a patologia e não abordarem como um todo, ou seja, tratavam o assunto de maneira muito superficial. Sendo assim, finalizamos a revisão de literatura com 21 artigos que abordavam especificamente a Síndrome Inflamatória Multissistêmica Pediátrica e serviram de base para a escrita do capítulo. No final, dois boletins epidemiológicos foram utilizados para auxiliar na escrita e compreensão da epidemiologia. 


\section{CONCLUSÃO}

Embora ainda pouco se saiba sobre a fisiopatologia da SIM-P, as informações disponíveis são suficientes para alertar o médico sobre a potencial gravidade da doença e a necessidade de estar alerta para identificar e investigar precocemente os casos suspeitos e monitorar as complicações através de vigilância contínua. A compreensão da necessidade de acompanhamento por equipe especializada e da constante atualização sobre a doença podem significar a diferença entre a vida e a morte do paciente.

\section{REFERÊNCIAS}

[1]. BOLETIM EPIDEMIOLÓGICO Nº 01 - 22/12/2020. BRASIL. Manual do Ministérios de Saúde. 2020. Disponível em: https://www.saude.go.gov.br/files//boletins/epidemiologicos/SIM-

P/Boletim\%20Epidemiol\%C3\%B3gico\%20S\%C3\%ADndrome\%20Inflamat\%C3\%B3ria\%20\%20Multissist\%C3\%AA mica\%20Pedi\%C3\%A1trica\%20(SIM-P)\%20n\%C2\%BA\%2001.pdf. Acesso em: 3 abr. 2021.

[2]. CAMPOS LR, et al. Síndrome Inflamatória Multissistêmica Pediátrica (MIS-C) temporariamente associada ao SARS-COV-2. Revista Residência Pediátrica, 2020; 10: 2.

https://residenciapediatrica.com.br/detalhes/514/sindrome $\% 20$ inflamatoria $\% 20$ multissistemica $\% 20$ pediatrica $\% 2$ 0-mis-c-\%20temporariamente\%20associada\%20ao\%20sars-cov-2. Acesso em: 2 abr.2021.

[3]. CASTRO P, Doença de Kawasaki. Anais Brasileiros de Dermatologia, 2009. Disponível em: https://www.scielo.br/scielo.php?script=sci_arttext\&pid=S0365-05962009000400002. Acesso em: 05 mar.2021.

[4]. Centers for Disease Control and Prevention. Multisystem Inflammatory Syndrome in Children (MISC) Associated with Coronavirus Disease 2019 (COVID-19) [Internet]. Atlanta: CDC; 2020 [citado em Mar 2021]. Disponível em: HAN Archive - 00432 | Health Alert Network (HAN).Acesso em: 15 mar. 2021.

[5]. CHEUNG EW, et al. Multisystem Inflammatory Syndrome Related to COVID-19 in Previously Healthy Children and Adolescents in New York City. JAMA 2020;234(3):294-6. https://jamanetwork.com/journals/jama/fullarticle/2767207 Acesso em:

[6]. DOLHNIKOFF M, et al. SARS-CoV-2 in cardiac tissue of a child with COVID-19-related multisystem inflammatory syndrome, The Lancet. Published online August 20, 2020 https://doi.org/10.1016/S23524642(20)30257-1. Acesso em: 03 mar.2021.

[7]. epidemiológicas. Research, Society and Development, v.10, n.3, e5710313020, 2021. Disponível em: https://rsdjournal.org/index.php/rsd/article/view/13020/11729. Acesso em: 05 mar.2021.

[8]. FELDSTEIN LR, et al. Multisystem inflammatory Syndrome in U.S. Children and adolescents. N Engl J Med, n. 383, p. 334-346, 2020. Disponível em: < https://www.nejm.org/doi/full/10.1056/NEJMoa2021680>. Acesso em: 06 abr.2021.

[9]. FERREIRA BWRC, et al. Síndrome Inflamatória Multissistêmica Pediátrica (SIM-P) temporariamente associada à COVID-19: um levantamento das características clínicas e

https://www.sbp.com.br/fileadmin/user_upload/22682b-NA_-_NotificacaoObrigatoria_no_MS_dos_SIM-Covid19.pdf.

[10]. JIANG L, et al. COVID-19 and multisystem inflammatory syndrome in children and adolescents. The Lancet Infectious Diseases, 2020. Disponível em: https://www.thelancet.com/journals/laninf/article/PIIS14733099(20)30651-4/fulltext. Acesso em: 11 mar.2021.

[11]. LINHARES M, et al. Reflexões baseadas na Psicologia sobre efeitos da pandemia COVID-19 no desenvolvimento infantil. Estudos de Psicologia (Campinas) vol.37, 2020. Disponível em: https://www.scielo.br/scielo.php?script=sci_arttext\&pid=S0103-166X2020000100510. Acesso em: 28 fev.2020.

[12]. LORIA MFB. Síndrome inflamatória multissistêmica associada à covid-19 em crianças e adolescentes. 2020. Disponível em:.https://repositorio.uniceub.br/jspui/bitstream/prefix/14537/1/21502838\%20-

\%20MARIA\%20FERNANDA\%20BUENO\%20LORIA.pdf. Acesso em: 12 mar.2021.

[13]. MANEJO, DIRETRIZES SOBRE O. DIAGNÓSTICO E. et al. GOVERNO DO DISTRITO FEDERAL. Nota Técnica № 10/2020 - SES/SAIS/CAT-COVID19. Brasília-DF, 10 de nov. 2020. Disponível em: http://www.saude.df.gov.br/wpconteudo/uploads/2020/02/Nota_Tecnica_DIRETRIZES-SOBRE-O-DIAGNOSTICO-E-MANEJO-CLINICO-\%E2\%80\%93FARMACOLOGICO-DA-COVID-19-NA-FAIXA-ETARIA-PEDIATRICA.pdf. Acesso em: 15 mar. 2021.

[14]. MOURA AÁ, et al. PROTOCOLO DE MANEJO CLÍNICO DE PACIENTES PEDIÁTRICOS COM COVID-19 - VERSÃO POCKET. Sociedade Alagoana de Pediatria, 2020. Disponível em:

https://www.sbp.com.br/fileadmin/user_upload/fluxo_covid19_pediatria_AL_pocket__2_pdf. Acesso em: 12 mar.2021.

[15]. MOURA SK, et al. Síndrome Inflamatória Multissistêmica Pediátrica (SIM-P), associada à COVID-19. TelessaúdeRS-UFRGS, 2020. Disponível 
em:https://www.ufrgs.br/telessauders/documentos/notas/Nota_Sindrome_Inflamatoria_Multissistemica_Pediatrica. pdf. Acesso em: 15 mar. 2021.

[16]. Notificação obrigatória no Ministério da Saúde dos casos de síndrome inflamatória multissistêmica pediátrica (SIM-P), et al. Departamento Científico de Infectologia (2019-2021), et al. Sociedade Brasileira de Pediatria, 07 Agosto de 2020.Disponível em: https://www.sbp.com.br/fileadmin/user_upload/22682b-NA__NotificacaoObrigatoria_no_MS_dos_SIM-Covid19.pdf. Acesso em: 15 mar. 2021.

[17]. PACÍFICO D, et al. Doença de Kawasaki e COVID-19: uma revisão de literatura. Revista Eletrônica Acervo Saúde, 2020. Disponível em: https://acervomais.com.br/index.php/saude/article/view/5085/3428. Acesso em: 19 mar. 2021.

[18]. RAMCHARAN T, et al. Paediatric inflammatory multisystem syndrome: temporally associated with SARSCoV-2 (PIMS-TS): cardiac features, management and short-term outcomes at a UK tertiary paediatric hospital. Pediatr Cardiol. 2020; (published online June 12.) https://doi.org/10.1007/s00246-020-02391-2. Acesso em 10 abr. 2021.

[19]. RIPHAGEN S, et al. Hyperinflammatory shock in children during COVID-19 pandemic. Lancet 2020;395:16078. https://www.thelancet.com/journals/lancet/article/PIIS0140-6736(20)31094-1/fulltext. Acesso em: 15 mar.2021.

[20]. SABARÁ Hospital Infantil, Quais lições já aprendemos no enfrentamento do COVID-19? 2020, Fundação José Luiz Egydio Setúbal. Disponível em: https://www.hospitalinfantilsabara.org.br/as-licoes-de-uma-pandemia-quemudou-tambem-o-mundo-hospitalar-2/. Acesso em: 16.abr.2021.

[21]. SCHUELER P. 511 casos de SIM-P no país. in: Fundação Oswaldo Cruz, 2021. Disponível em: https://www.bio.fiocruz.br/index.php/br/noticias/2099-511-casos-de-sim-p-no-pais. Acesso em: 3 abr. 2021.

[22]. SHEKERDEMIAN LS, et al. Characteristics and outcomes of children with coronavirus disease 2019 (COVID19) infection admitted to US and Canadian pediatric intensive care units. JAMA pediatrics, v. 174, n. 9, p. 868-873, 2020. Disponível em: https://jamanetwork.com/journals/jamapediatrics/fullarticle/2766037. Acesso em: 12 de abr.2021.

[23]. TOUBIANA J, et al. Kawasaki-like multisystem inflammatory syndrome in children during the COVID-19 pandemic in Paris, France: prospective observational study. BMJ. 2020; 369m2094. Disponível em: https://pubmed.ncbi.nlm.nih.gov/32493739/. Acesso em: 12 mar.2021.

[24]. VARGA Z, et al. Endothelial cell infection and endotheliitis in COVID-19. Lancet 2020; 395: 1417-18. Disponível em: https://www.thelancet.com/journals/lancet/article/PIIS0140-6736(20)30937-5/fulltext. Acesso em: 08 mar.2021.

[25]. VERDONI L, et al. An outbreak of severe Kawasaki-like disease at the Italian epicentre of the SARS-CoV-2 epidemic: an observational cohort study. Lancet 2020;395:1771-8. Disponível em: https://www.thelancet.com/journals/lancet/article/PIIS0140-6736(20)31103-X/fulltext. Acesso em: 12 mar.2021.

[26]. WHITTAKER E, et al. Clinical characteristics of 58 children with a pediatric inflammatory multisystem syndrome temporally associated with SARS-CoV-2. Jama, v. 324, n. 3, p. 259-269, 2020. Disponível em: https://jamanetwork.com/journals/jama/fullarticle/2767209. Acesso em 13 mar.2021. 


\section{Capítulo 12}

Estratégias para prevenção do câncer de testículo e a importância do enfermeiro: Revisão de literatura

Silvia Roberta de Lima Cardoso

Raquel Mendes Rubenick

Alexandre Lazzarini Machado

Mirela Tonato Vieira

Kelin Rodrigues Aguiar

Simone dos Santos Nunes

Resumo: Esta pesquisa documental tem o objetivo identificar na literatura estratégias para prevenção do câncer testicular, fatores de risco, distúrbios das complicações tardias e importância do enfermeiro na educação em saúde, com inclusão do assunto nas escolas, mídias, lugares de concentração do público masculino. Os impactos estatísticos, quanto ao cuidado e a estruturação dos serviços, mostram este como pouco resolutivo, sendo necessário o enfermeiro agente importante no desenvolvimento de estratégias que facilitem o vínculo, aproximação, ruptura da cultura de masculinidade e estimule o autocuidado masculino (FERREIRA et al, 2017).

Palavras-chave: Câncer de testículo. Enfermagem. Educação em saúde. 


\section{INTRODUÇÃO}

Câncer testicular (CT) é o mais comum entre homens jovens de 15 a 45 anos. A incidência está aumentando e pouca atenção é dada na recomendação do autoexame uma vez por mês durante o banho quente, para prevenção e diagnóstico precoce em países em desenvolvimento. As células normais sofrem mutação, crescem apressadamente e constituem um tumor. Se desenvolve em células germinativas responsáveis pela produção do espermatozoide, tipo mais encontrado em $95 \%$ dos casos. Geralmente tem aparência externa de nódulo, dor e sensação de peso no escroto (GUTEMA et al,2018).

Altamente curável quando diagnosticado e tratado precoce e com terapia apropriada mesmo disseminado. Taxa de $99,2 \%$ se não for para linfonodos fora do testículo. Causa impacto psicológico no homem, na família e na comunidade (GUTEMA et al,2018). Causa distúrbios clínicos e fisiológicos em homens que apresentam malignidade. Destaco a importância do enfermeiro na educação em saúde nas estratégias de detecção precoce (LIBBY et al, 2018).

A bolsa testicular é constituída de sete camadas (pele, dartos, fáscia espermática externa, fáscia cremastérica, fáscia espermática interna e túnica vaginal visceral e parietal). Apresenta septo mediano que divide a bolsa testicular em dois compartimentos, contendo cada um, o testículo e epidídimo, além dos seus respectivos apêndices. Esses órgãos são acometidos por afecções agudas que, conforme a etiologia, podem ser classificadas em processos vasculares, infecciosos ou inflamatórios, traumáticos ou tumorais (PETERLINI et al, 2014).

Níveis de concentrações hormonais de androstenediona neonatais foram associados com aumento de causa ao desenvolvimento na adolescência de tumor testicular (LIBBY et al, 2018). Estudos mostram evidências relacionadas entre uso de Cannabis com risco 2,5 vezes mais alto e tumor testicular (CALLAGHAN et al, 2017).

O tratamento do câncer causa distúrbios no sistema endócrino acompanhado de sintomas somáticos, perturbando o sistema pituitário-gonadal, levando o sistema microcelular a apresentar sintomas visíveis. O sistema andrógeno que estimula e controla as características masculinas sofrem distúrbios com a malignidade do câncer de testículo levando ao aparecimento de outras patologias (WIECHNO et al, 2017).

A importância da atuação do enfermeiro na saúde do homem nas Unidades de Saúde para fornecer esclarecimentos, informações, consulta de enfermagem e estímulo à realização de prevenção ao auto cuidado. Os enfermeiros precisam tornar as práticas públicas atrativas, porque o público masculino cuidam menos da própria saúde. Geralmente as políticas de atenção foram voltadas para as mulheres, idosos e crianças, fato que comprova a mortalidade dos homens ser maior e precoce (FERREIRA et al, 2017).

Dados do ministério da Saúde (MS) mostram que gastos com internações masculinas superam diferenças de gastos anuais exorbitantes. A taxa de mortalidade é 3 vezes maior entre homens. Muitas morbidades poderiam ser evitadas com elaboração de políticas públicas voltadas para o homem serem abordadas. Em 2009 o MS lançou Portaria 1.944 em 27 de agosto Atenção Integral à Saúde do Homem com a Política Nacional de Atenção para este acolhimento (FERREIRA et al, 2017).

Os impactos estatísticos social no cuidado quanto estruturação dos serviços, mostram este como pouco resolutivo, sendo necessário o enfermeiro agente importante no desenvolvimento de estratégias que facilitem o vínculo, aproximação, ruptura da cultura de masculinidade e estimule o autocuidado masculino (FERREIRA et al, 2017).

As células testiculares de Leydig, tem potencial maligno, doença rara, massa indolor. Necessário exame histológico para determinar a diferenciação das células germinativas (ZHU, YUN, LI, 2018).

Esta pesquisa, portanto, tem o objetivo de identificar na literatura estratégias para prevenção do câncer testicular, fatores de risco, distúrbios das complicações tardias, importância do enfermeiro na educação em saúde, com inclusão do assunto nas escolas, mídias, lugares de concentração do público masculino, como academias, sala de espera e jornais de grande circulação. 


\section{REVISÃO TEÓRICA}

Estudos realizados em diferentes regiões identificam baixo conhecimento em relação a câncer testicular, fatores de risco e autoexame no escroto. Participantes universitários de estudo transversal na cidade de Bahir Dar, perto da capital da Etiópia com questionário autoadministrado identificou baixa prática de autoexame testicular e falta de conhecimento entre estudantes sobre o assunto. A técnica de amostragem selecionou 884 alunos do sexo masculino. 11,8\% realizaram autoexame um ano antes da pesquisa. Como resultado foi apontado a comunicação sendo necessária para mudança de comportamento e conhecimento do autocuidado dos alunos a respeito do câncer de testículo (GUTEMA et al, 2018).

0 tumor de células germinativas testiculares é o mais comum entre adolescentes e jovens. Com dois tipos de histologia: Seminomas (25 a 45 anos) e não seminomas (adolescentes, 30 anos) e desenvolvem em jovens e bebês até 4 anos. 0 câncer de testículo em jovens com fatores genéticos é grande (LIBBY et al, 2018).

Testículos são desenvolvidos por fatores hormonais de estrógenos e androgênio. A neoplasia in situ, mais comum entre os jovens é parecido com aos gonócitos fetais, levando a presunção deste ser manifestação tardia de carência fetal. Outra suposição, é o surto hormonal que o bebê sofre ao nascer. Estudos também focalizam os hormônios durante a gravidez e tumores 20 a 40 anos depois, no sexo masculino com o desiquilíbrio andrógenos e estrógenos. Este é o primeiro marco sobre o aumento de câncer de testículo e a associação de andrógenos (LIBBY et al, 2018).

No globo, 180 milhões de pessoas consumiram Cannabis no ano de 2017 em todo o globo. A população de usuários tem a confiança que esta não confere riscos. União Europeia, Austrália e Américas fizeram reformas no controle da Cannabis. É importante por este motivo estudos para avaliar o impacto do seu uso na saúde de usuários. Foram realizados 3 estudos nos Estados Unidos com 49.393 homens jovens suecos durante o processo de recrutamento do serviço miliar com objetivo de avaliar ao longo de 42 anos de acompanhamento no aditamento de câncer testicular.

A coleta de dados baseou-se em questionário na hora do recrutamento, com perguntas estruturadas no estilo de vida e rotina dos participantes (CALLAGHAN et al, 2017).

A vinculação dos registros foi observado o uso de cannabis mais de 50 vezes na vida, com risco 2,5 vezes maior de câncer testicular. 0 fator que a cannabis usa para afetar as células germinativas testiculares não está completamente claro. Os compostos tetrahidrocanabinol e canabidiol ligam-se a receptores canabinóides (CB1 e CB2) em órgãos humanos. Assim nos testículos hormônios importantes são afetados. Níveis de testosterona, hormônio folículo estimulante e luteinizante e as células de sertoli são atingidos. Resultados devem ser cuidadosamente analisados. Há necessidade de mais pesquisas nesta área (CALLAGHAN et al, 2017).

\section{MÉTODO}

O estudo consiste em uma revisão de natureza bibliográfica e documental descritiva, que aborda a educação em saúde desenvolvida pelo enfermeiro para mostrar ao homem a importância da sua autonomia na prevenção de câncer de testículo.

Constitui-se como uma revisão de literatura do tipo narrativa com abordagem qualitativa, por meio da qual se buscou conhecer as evidências científicas de risco, prevenção e detecção do câncer de testículos e a importância do enfermeiro nas estratégias de educação em saúde em doenças preveníveis como câncer de testículos.

Como corpus de pesquisa de dados, utilizou-se a Biblioteca Virtual em Saúde (BVS) com descritores: "neoplasias testiculares" "enfermagem" AND "regional" abriram 100 trabalhos. 99 não serviram a pesquisa, 2 eram repetidos e 1 respondeu a pesquisa, mas o ano de publicação 2011. Este usamos para direcionar o conhecimento devida a importância do conteúdo. Com os descritores: "câncer testicular" AND "regional" e os filtros, AND "MEDLINE" AND "Neoplasias Testiculares" OR "Orquiectomia" AND "humans" AND "neoplasias" OR "enfermagem" AND year "2014" OR "2017"AND type:"article" abriram 118 trabalhos. Cinco responderam à pesquisa. Cento e treze não responderam a questão norteadora.

Na Biblioteca PubMed com os descritores: "neoplasias testiculares" abriram 31380 trabalhos. Utilizando os filtros: texto completo, publicado nos últimos 5 anos, Humanos. Ficaram 975 trabalhos. Após ler os trabalhos na íntegra, cinco corresponderam objetivo da pesquisa. Foram escolhidos para o trabalho os que melhor respondiam a pergunta norteadora. Em um primeiro momento não realizamos marco temporal. 
Em seguida aplicamos filtros. Os fatores de inclusão foram artigos completos disponíveis on-line e obras literárias. Como fatores de exclusão teses, dissertações e cartilhas. Não aplicamos restrições a respeito de idioma. A busca dos dados ocorreu e agosto de 2019.

Foi utilizada a análise de conteúdo proposta por Minayo (2014), que aborda as etapas: (a) pré-análise com leitura compreensiva dos textos transcritos, identificando especificidades retomando as hipóteses e objetivos iniciais da pesquisa; (b) exploração do material visando alcançar o núcleo de compreensão do texto por meio da elaboração de categorias de análise e agrupando trechos de depoimentos significativos; (c) tratamento e interpretação dos dados, que culminou com a definição de unidades de significado, orientadas da discussão dos dados (MINAYO, 2014).

\section{ANÁLISE E DISCUSSÃO DOS RESULTADOS}

A testosterona é um hormônio. Estes são mensageiros químicos que controlam atividades em outros órgãos. Transportados pelo sangue.Com a idade é normal cair um pouco os níveis de testosterona, mas o tratamento oncológico afeta significativamente as concentrações, perturbando o funcionamento e homeostase do metabolismo. Levam as complicações tardias como a síndrome metabólica. Hormônios sexuais são importantes para o bem estar. Agem em estruturas do cérebro sendo as mais importantes o hipocampo, corpo da amígdala e córtex pré-frontal WIECHNO et al, 2017).

A terapia oncológica, geralmente usa um composto chamado cisplatina (composto da química inorgânica, um metal). Por ser tóxica para célula causa danos nas células de Leydig, causando diminuição da testosterona. Este hormônio a baixo de $15 \mathrm{nmol}$ mostra risco de síndrome metabólica. Pacientes que necessitam da orquiectomia ou que tem níveis de testosterona diminuídos, apresentam excesso de peso, aumento de colesterol, complicações cardiovasculares e risco de Infarto Agudo do Miocárdio(IAM). Aumenta risco de fraturas, osteoporose sobe risco para 49,2\% após 2 anos. Necessário suplementação de vitaminas (ZHU, YUN, LI, 2018).

Foi confirmado na literatura efeitos negativos na falta de testosterona no humor, funções sexuais e ansiedade. Faltam estudos dos efeitos da suplementação da testosterona após tratamento de quimioterapia, radioterapia ou orquiectomia. Sabe-se neste momento que uso da suplementação aumenta a força muscular, diminui circunferência da cintura e resistência à insulina. Alivia depressão e retorno da libido (WIECHNO et al, 2017).

Com a quimioterapia com componentes de cisplatina, os mais usados em tumores de testículos, cerca de $30 \%$ não surtirão efeitos na remissão e cura da doença. Com tratamento de resgate $50 \%$ terão sobrevivência. $15 \%$ a $20 \%$ dos pacientes serão vencidos pela doença. Mecanismos de resistência celular a cisplatina ainda precisam ser elucidados. Há necessidade de novas opções de tratamentos e biomarcadores. Situação rara a resistência a este fármaco utilizado em dosagem padrão, pode ter origem multifatorial. Em resumo, novos estudos com o 5-azacitidina com efeitos próapoptóticos supera a cisplatina em células tumorais germinativas. 0 5-aza é uma droga usada nas síndromes mielodisplásicas e leucemia mielóide. Terapêuticas combinadas em câncer de ovário insensível a platina teve boas respostas (OING et al, 2018).

Atualmente há um estudo acontecendo em Indiana University Hospital, EUA que investiga o uso de combinação de cisplatina+ guadecitabina em pacientes com neoplasia testicular refratária (OING et al, 2018).

Tumores testiculares de células de Leydig dos túbulos seminíferos é uma massa única, maligna com ou sem anormalidades hormonais. Quando têm anormalidades hormonais causam perda da libido e também podem causar ginecomastia. Os picos de idade são aos 3 a 9 anos e aos 30 e 60 anos. Os distúrbios hormonais se dão pela produção desordenada com aumento de testosterona e estrógenos. Autores relatam ser possível diferenciar este tumor observando alguns aspectos: pacientes com mais de 40 anos, tumor maior de $5 \mathrm{~cm}$, margens infiltrativas, hemorragia e necrose além do parênquima testicular. Cirurgia é o melhor tratamento. Quando há metástases, o tratamento não é bem correspondido (ZHU, YUN, LI, 2018). 
Figura 1- Tumor de testículo associado à microlitíase (microcalcificações no interior dos túbulos seminíferos).

(1) Testículo exposto; (2) tumor; (3 e 4) macroscopia tumor;(5) testículo reconstruído.

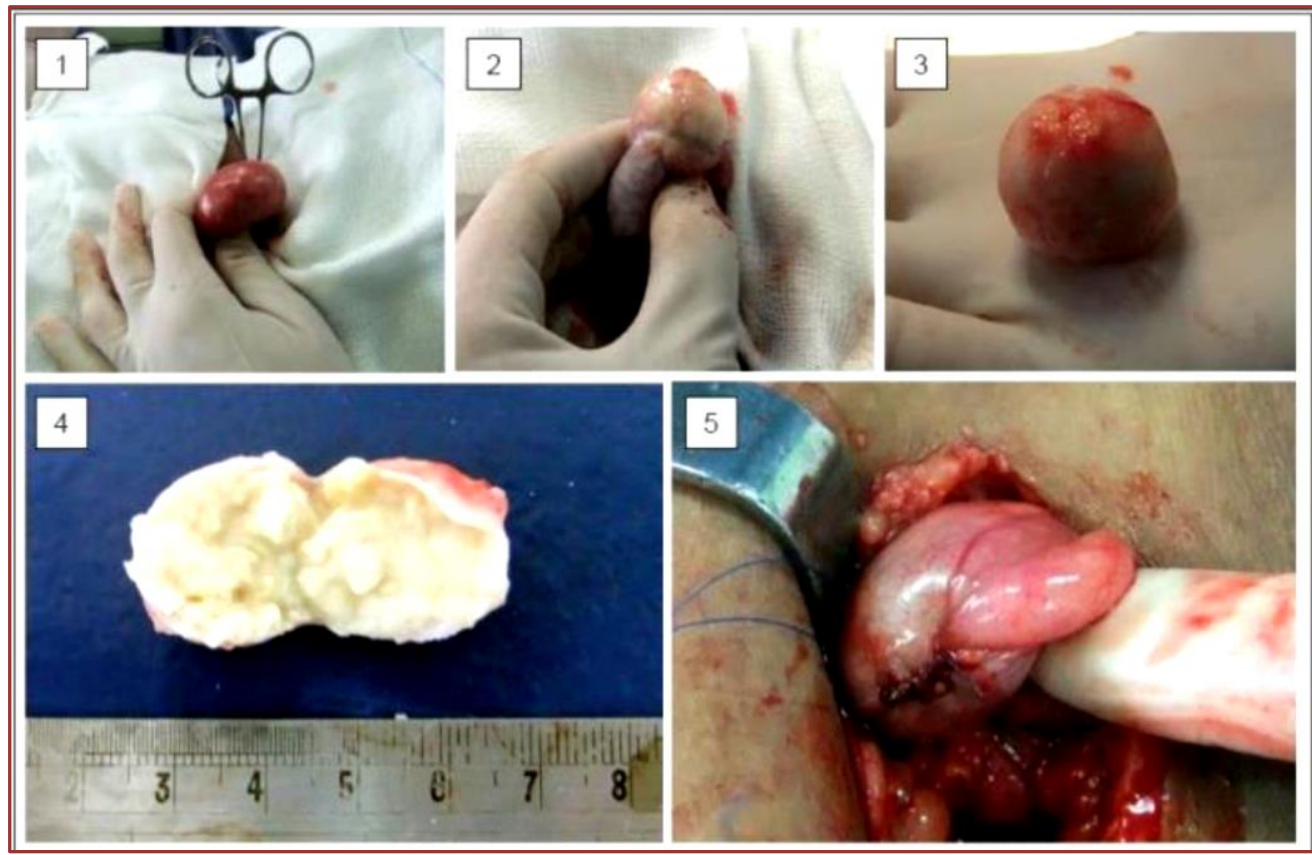

Fonte: (JESUS et al, 2013)

\section{CONCLUSÕES}

O Câncer testicular afeta homens jovens, em idade fértil e laboral. Pode acometer crianças e homens mais velhos a partir de 50 anos. Sendo nestes casos mais raro. Curável quando diagnosticado precoce, e com problemas tardios importantes nos homens que necessitam de orquiectomia radical (castração) pela deficiência do hormônio testosterona.

Estudos evidenciam que homens tem pouco ou nenhum conhecimento sobre câncer de testículo e impactos que carência ou falta de hormônios essenciais à saúde masculina pode causar.

Políticas relacionadas a legalização da cannabis não apresentam conhecimento sobre abalos nos tecidos, órgãos, inclusive testículos. A análise de coleta de dados realizada com questionários em recrutamento militar de homens Suecos, em seguimento de 42 anos, descobriram que o uso de cannabis está associado ao risco de desenvolvimento de câncer de testículo. Importante abordar o tema no território, comunidade e locais de concentração masculina, como academias, quarteis e clubes de sauna.

A enfermagem ocupa papel de destaque em estratégias de promoção e educação para atrair a população masculina para unidades de saúde e sensibiliza-los quanto a importância do autocuidado. A sobrevida está relacionada a detecção precoce.

Precisamos juntar esforços com a equipe de enfermagem para divulgação de informações. A importância do auto exame no banho, inclusão do assunto nas escolas, cartazes informativos em banheiros masculinos, em banheiros femininos para levar conhecimento as mulheres que cuidam de filhos, maridos e companheiros. Orientar como deve ser apalpado os testículos, sem aplicar força, segurando um por vez entre o polegar e os outros dedos. Testículos normais, não têm nódulo, são firmes.

O enfermeiro deve abordar o assunto nas consultas de enfermagem, estimular informação de sexo seguro e outros agravos. As informações da saúde do homem podem ocorrer durante as visitas domiciliares, orientar quanto a importância de higiene, pois esta é relacionada diretamente com o câncer de pênis.

A saúde do homem é um desafio. Sociedade culturalmente machista e com valores distorcidos em que o homem precisa parecer "forte", fazendo muros entre o homem e seu cuidado com a saúde. 
O enfermeiro precisa estabelecer vínculos para acompanhamento rotineiro preventivo. Buscar junto a equipe métodos de organização no atendimento para aqueles homens que não podem comparecer a unidade em horário de trabalho.

\section{REFERÊNCIAS}

[1] BANDAK, M. et al. Um estudo randomizado duplo-cego da terapia de reposição de testosterona ou placebo em sobreviventes de câncer testicular com insuficiência de células de Leydig leve (Einstein-intervenção). Bandak et al. BMC Cancer (2017) 17:461.

[2] CALlaghan, R. C. et al. Uso de Cannabis e Incidência de Câncer Testicular: Um Seguimento de 42 Anos de Homens Suecos entre 1970 e 2011. Cancer Epidemiol Biomarkers Anterior 1 de novembro de 2017 (26) (11)1644-1652.

[3] FERREIRA, S. R. S. PÉRICO, L. A. D. DIAS, V. R. F. G. Atuação do enfermeiro na Atenção Primária à Saúde. -1. Ed. Rio de Janeiro: Atheneu, 2017.690p.

[4] GUTEMA, H. et al. Auto-exame testicular entre estudantes da Universidade Bahir Dar: aplicação de modelo comportamental integrado. BMC Cancer (2018) 18:21.

[5] JESUS, L. E. et al. Tumor de Testículo associado a microlitíase. Ver. Paul. Pediatr., São Paulo, V. 31, no. 4. P. 554-558, Dec.2013.

[6] KERNS, S. L. et al. Carga Cumulativa de Morbidade Entre Sobreviventes de Câncer Testicular Após Quimioterapia Baseada em Cisplatina: Um Estudo Multi-Institucional. Journal of oncology clínico: jornal oficial da American Society of Clinical Oncology vol. 36,15 (2018): 1505-1512.

[7] LIBBY M. M. et al. Concentrações hormonais neonatais e risco de tumores de células germinativas testiculares (TGCT). Cancer Epidemiol Biomarkers Anterior 1 de Abril de 2018 (27) (4) 488-495.

[8] MINAYO, M. C. S. O desafio do conhecimento: pesquisa qualitativa em saúde. 8.ed. São Paulo: HucitecAbrasco, 2014.

[9] OING, C. et al. A 5-azacitidina exerce efeitos pró-apoptóticos prolongados e supera a resistência à cisplatina em células tumorais de células germinativas não seminomatosas. International journal of molecular sciencesvol. 20,1 2121 dez. 2018.

[10] PETERLINI, F. L. et al. Emergências clínicas- São Paulo (SP): Martinari, 2014.

[11] PILTOFT, J. S. et al. Fatores de risco iniciais para câncer testicular: um estudo de caso-coorte baseado no Registro de Registros de Saúde da Escola de Copenhague. Volume 56, 2017 - Edição 2 : Simpósio Europeu de Reabilitação e Sobrevivência do Cancro (ECRS 2016), Copenhaga, setembro de 2016. 11

[12] SOUZA, K. W. de et al . Estratégias de prevenção para câncer de testículo e pênis: revisão integrativa. Rev. esc. enferm. USP, São Paulo , v. 45, n. 1, p. 277-282, Mar. 2011.

[13] WIECHNO, P. J. et al. Dinâmica de distúrbios hormonais após orquiectomia unilateral para tumor testicular. Rev.Med Oncol (2017) 34:84.

[14] WIECHNO, P. J. et al. Significado clínico dos distúrbios da secreção androgênica em homens com malignidade. Med Oncol (2017) 34: 123.

[15] ZHU, J. YUN, L. LI, H. Manejo do tumor de células testiculares de Leydig. Medicina: junho de 2018 - Volume 97 - Edição 25 - p e11158. 


\section{Capítulo 13}

Rastreamento de câncer de mama em Alagoas: Uma análise a partir dos dados do sistema de informações do Sistema Único de Saúde

\section{Martta Laiany Martins Machado \\ Jucélia Rodrigues Oliveira \\ Zenaira da Silva Santos \\ Josefina da Silva Santos}

Resumo: Objetivo:Analisar a distribuição de equipamentos mamográficos e a oferta dos exames de mamografia realizadas pela população feminina, no âmbito do Sistema Único de Saúde (SUS) do estado de Alagoas e seus municípios, no período de 2015 a 2019. Métodos: estudo descritivo de caráter exploratório, baseado na análise quantitativa de dados secundários obtidos através do Sistema de Informação do Câncer (SISCAN) e do Cadastro Nacional de Estabelecimentos de Saúde (CNES). Resultados: apesar da capacidade total de aparelhos instalada no estado ser superior à considerada necessária pelo Ministério da Saúde (MS), somente 15,69\% dos municípios alagoanos possuíam mamógrafos em uso no ano de 2019. Apenas 17,18\% do total da população feminina, entre 50 e 69 anos de idade, realizou o exame de mamografia para rastreio do câncer de mama. Observou-se ainda, elevada porcentagem de mulheres (38,69\%) que realizaram mamografias com indicação de rastreio fora da faixa etária preconizada pelo MS. Conclusão: o número suficiente de equipamentos não indica a garantia de acesso aos serviços mamográficos. Alagoas necessita da redistribuição dos equipamentos e aprimoramento do rastreio de câncer de mama para população-alvo, assegurando o acesso ao procedimento diagnóstico e acompanhamento adequado para efetiva diminuição na mortalidade por essa neoplasia maligna.

Palavras-chave: Mamografia; Programas de Rastreamento; Alocação de Recursos para Atenção à Saúde; Detecção Precoce de Câncer; Acesso aos Serviços de Saúde. 


\section{INTRODUÇÃO}

O câncer é uma das neoplasias malignas de maior impacto na comunidade mundial, tanto em número de novos casos, como de mortalidade. Em 2018, o câncer de mama foi o segundo tipo de maior incidência no mundo, representando 2,09 milhões de casos, e o quinto em número de óbitos ${ }^{1}$. No Brasil, excluindo-se os tumores de pele não melanoma, o câncer mamário foi o que mais acometeu a população do sexo feminino no ano de 2019, com estimativa de 66.280 novos casos para cada ano do triênio de 2020 a $2022^{2}$. Foi o tipo de câncer com a maior taxa de mortalidade entre as mulheres brasileiras em 2018, com 17.572 óbitos, o equivalente a um risco de 16,40 por $100 \mathrm{mil}^{2}$.

A mamografia é um método efetivo na detecção do câncer de mama, possibilita início precoce do tratamento e, em decorrência, melhoras no prognóstico com redução nas taxas de mortalidade. 0 rastreamento mamográfico, através da implementação de programas estruturados contínuos, é responsável pela diminuição de 20 a 30\% na mortalidade por esta neoplasia3,4,5.

Ocorrem divergências quanto à faixa etária e a periodicidade da feitura do exame na literatura de diferentes instituições nacionais e internacionais. A Sociedade Brasileira de Mastologia (SBM), o Colégio Brasileiro de Radiologia e Diagnóstico por Imagem (CBR) e a Federação Brasileira das Associações de Ginecologia e Obstetrícia (FEBRASGO) recomendam a mamografia anual para mulheres a partir dos 40 anos de idade ${ }^{6}$. O Ministério da Saúde, em consonância com a Organização Mundial da Saúde (OMS), reconhece a realização de mamografias bienais para mulheres entre 50 e 69 anos de idade7. Apesar da recomendação, o Brasil apresenta um baixo alcance do rastreamento mamográfico.

Os resultados da última Pesquisa Nacional de Saúde (PNS) divulgada indicam que 40\% das mulheres, na faixa etária de 50 a 69 anos de idade, não realizam o exame de rastreio ${ }^{8}$. Quando inserimos o recorte de raça/etnia à análise, percebemos que as mulheres autodeclaradas negras e pardas representam, respectivamente, $45,8 \%$ e $47,1 \%$ da população feminina que não realizou a mamografia de forma preventiva ${ }^{8}$. Outro fator que demonstra a desigualdade no acesso aos mamógrafos é a concentração dos serviços de saúde em grandes centros urbanos, em detrimento de áreas rurais e/ou periféricas.

Entre as ações nacionais de controle do câncer de mama, o Ministério da Saúde, em parceria com o Instituto Nacional do Câncer, implementou em 2009 o sistema de informação de controle do câncer de mama (SISMAMA), atualizado em 2013 pelo sistema de informação do câncer (SISCAN), essencial na disseminação de informações em saúde para gestão e controle social do SUS e apoio a pesquisas na área de saúde.

As regiões Norte e Nordeste apresentam maior carência em serviços de saúde, incluindo espacialização desigual dos equipamentos de mamografia ${ }^{9}$. Desta forma, torna-se relevante a análise dos serviços de rastreamento no estado de Alagoas para identificar especificidades pertinentes que contribuam com a gestão, planejamento e implantação de possíveis programas de rastreamento de mamografias mais adequados à realidade desse estado, visando a atender a população de forma mais equânime.

Este artigo teve por objetivo, analisar a distribuição de equipamentos mamográficos e a oferta dos exames de mamografia realizados pela população feminina, no âmbito do Sistema Único de Saúde (SUS) do estado de Alagoas e seus municípios.

\section{MÉTODOS}

O estudo ora apresentado possui caráter exploratório, de natureza descritiva, baseado na análise quantitativa de dados secundários, referentes ao estado de Alagoas e seus municípios, no período de 2015 a 2019. Alagoas localiza-se na região do nordeste brasileiro e apresenta $27.843,295 \mathrm{~km}^{2}$. Sua configuração territorial é constituída por 102 municípios, distribuídos em 10 regiões de saúde (RS) e organizados em duas macrorregiões que obedecem a critérios de densidade demográfica e de tecnologia de atenção especializada e hospitalar ${ }^{10}$. A população total estimada em 2019 era de 3.336 .911 habitantes, sendo $52,02 \%$ do sexo feminino, caracterizada pela maior desigualdade de renda do país entre os trabalhadores em idade produtiva ${ }^{11}$.

Os dados utilizados são secundários e foram obtidos na plataforma de Informações de Saúde (TABNET) do Departamento de Informação e Informática do SUS (DATASUS), sendo a consulta realizada no: 
a) Sistema de Informação do Câncer (SISCAN) - onde estão registrados os exames de rastreamento e investigação diagnóstica dos cânceres do colo do útero e de mama, assim como outras informações importantes para o planejamento e a avaliação das ações de controle dos cânceres do colo do útero e mama no Brasil.

b) Cadastro Nacional de Estabelecimentos de Saúde (CNES) - onde estão cadastrados todos os estabelecimentos de saúde, sejam públicos, conveniados e/ou privados, que realizam qualquer tipo de serviço de atenção à saúde em território nacional.

c) População Residente - onde é possível encontrar a projeção da população das unidades da federação por sexo e grupos de idade obtidas do sítio do IBGE.

Os dados coletados foram organizados em planilha Excel Microsoft 365, para viabilizar o processo de análise de dados, que nos facilitou o cruzamento das informações referentes ao número de exames realizados por local de residência e faixas etárias preconizadas, a saber: de 40 a 49 anos e de 50 a 69 anos.

Para os cálculos do número de exames mamográficos considerados necessários para a população-alvo, do número de mamógrafos necessário para atender o estado alagoano (Quadro 1) e análise dos resultados, utilizou-se as orientações do Departamento de Regulação, Avaliação e Controle de Sistemas do Ministério da Saúde e do INCA ${ }^{12,13}$.

Quadro 01 Formulas usadas para cálculo das variáveis. Número necessário de mamografias estimadas por ano (NM)

\begin{tabular}{|c|c|}
\hline \multicolumn{2}{|c|}{ Número necessário de mamografias estimadas por ano (NM) } \\
\hline $\begin{array}{c}\text { D1 + D2 + R1 + Ou } \\
10 \% \text { das mulheres entre } 40 \text { a } 49 \text { anos }\end{array}$ & $\begin{array}{c}\text { D2 (indicação de mamografia diagnóstica) }=8,9 \text { das mulheres entre } \\
50 \text { a } 69 \text { anos }\end{array}$ \\
\hline $\begin{array}{c}\text { Ou (outras indicações) }=10 \% \text { das mulheres } \\
\text { entre } 40 \text { a } 49 \text { anos }\end{array}$ & R1 (indicação rastreamento) = 50\% das mulheres entre 50 a 69 \\
\hline \multicolumn{2}{|c|}{ Número necessário de mamógrafos (Nm) } \\
\hline \multicolumn{2}{|c|}{ NM/6.758 } \\
\hline \multicolumn{2}{|c|}{5096 x Mamógrafos disponíveis no SUS } \\
\hline
\end{tabular}

Fonte: INCA, MS.

Vale ressaltar que, inicialmente, o interesse do presente artigo era avaliar a distribuição dos mamógrafos e exames mamográficos no período de 2015 a 2020 (último ano de competência completo disponibilizado pelo DATASUS até a presente data). Porém, durante a elaboração deste estudo, a pandemia provocada pela Covid-19 acometeu diversos países, inclusive o Brasil. Como consequência ocorreram atrasos de diagnóstico e aumento significativo na interrupção das terapias, enquanto ensaios clínicos e produção de pesquisas específicas, diminuíram bruscamente ${ }^{14}$. Desta forma, demonstramos a necessidade de outras investigações, que engendrem a hipótese dos afetamentos da Covid-19 na dinâmica dos serviços mamográficos oferecidos pelo serviço público brasileiro de saúde.

\section{RESULTADOS}

Alagoas apresentou aumento de 124,31\% nos exames de mamografias realizados pelo Sistema Único de Saúde no período de 2015 a 2019 (Tabela 1). Observou-se um número médio de 36 equipamentos mamográficos, com o desvio padrão de 1,87, correspondentes ao período analisado. 
Tabela 01 Número de mamografias realizadas e necessárias por local de residência, números de mamógrafos disponíveis e necessários e capacidade instalada.

\begin{tabular}{|c|c|c|c|c|c|}
\hline Ano & $\begin{array}{c}\text { Quantidade de } \\
\text { Mamografias } \\
\text { Realizadas por ano }\end{array}$ & $\begin{array}{c}\text { Número necessário de } \\
\text { mamografias estimadas } \\
\text { por ano }\end{array}$ & $\begin{array}{c}\text { Mamógrafos } \\
\text { disponíveis no } \\
\text { SUS }\end{array}$ & $\begin{array}{c}\text { Número } \\
\text { necessário de } \\
\text { mamógrafos }\end{array}$ & $\begin{array}{c}\text { Capacidade } \\
\text { instalada por } \\
\text { ano }\end{array}$ \\
\hline 2019 & 81.708 & $216.197,22$ & 39 & 31,99 & 263.562 \\
\hline 2018 & 78.138 & $180.851,38$ & 36 & 26,76 & 243.288 \\
\hline 2017 & 71.254 & $209.724,27$ & 36 & 31,03 & 243.288 \\
\hline 2016 & 37.813 & $203.696,88$ & 35 & 30,14 & 236.530 \\
\hline 2015 & 36.764 & $197.899,26$ & 34 & 29,28 & 229.772 \\
\hline
\end{tabular}

Em 2019, o estado apresentava 39 mamógrafos disponíveis no SUS distribuídos por seus 102 municípios, dos quais somente 15,69\% possuíam o aparelho. Para a alocação adequada dos equipamentos é necessário considerar o acesso do público-alvo ao exame. O MS propõe, como parâmetro para o planejamento de ações e serviços de saúde no âmbito do SUS, observar duas variáveis correlacionadas ao deslocamento: tempo e espaço. 0 tempo de deslocamento da população-alvo até o mamógrafo não deve ultrapassar 60 minutos, enquanto a distância percorrida não deve ser superior à 60 quilômetros ${ }^{13}$. Os vazios na provisão do equipamento (Figura 01), com áreas superiores a $60 \mathrm{~km}$, evidenciam uma provável inadequação de oferta e demanda.

Figura 01 - Distribuição espacial dos mamógrafos no estado de Alagoas por município no ano de 2019.

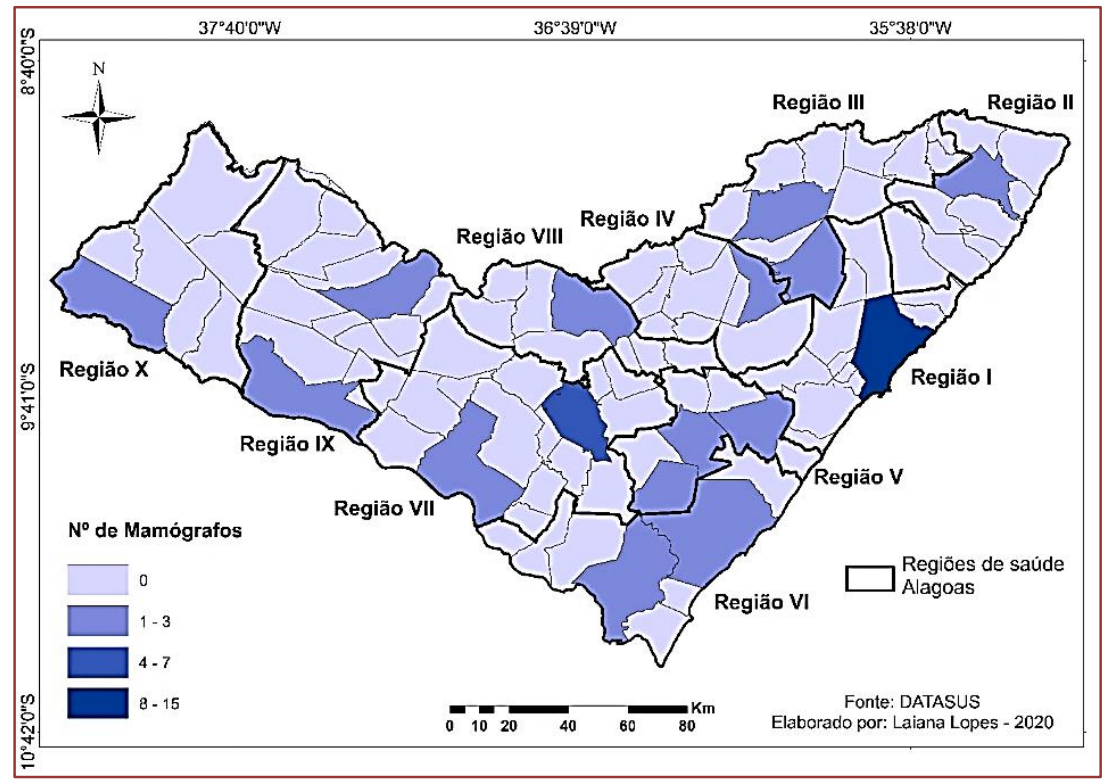

No ano de 2019 foram realizadas um total de 81.708 mamografias por local de residência, no estado de Alagoas, das quais 111 foram desconsideradas para fins desta construção, haja vista terem sido realizadas na população do sexo masculino. Assim, com relação as mamografias realizadas na população feminina, 99,35\% tiveram como indicação clínica o rastreio efetivo para detecção do câncer de mama (Tabela 02).

Com relação a distribuição de exames realizados por grupo etário no ano de 2019, observa-se que do total de mulheres na faixa etária de 50 a 69 anos (289.344), apenas 17,18\% realizou o exame; do total de mulheres que realizaram mamografias nas diferentes faixas etárias (1.736.031), 61,31\%, encontra-se 
entre 50 e 69 anos de idade e 29,12\% entre 40 e 49 anos; 9,57\% situam-se nas demais faixas etárias, ou seja, fora da faixa etária alvo, com idades inferiores a 40 e/ou superior a 70 anos de idade (Tabela 2).

Tabela 02 - Distribuição do número de mamografias realizadas, por local de residência, faixa etária e indicação clínica, para o sexo feminino em 2019.

\begin{tabular}{|c|c|c|c|}
\hline \multirow{2}{*}{ População alvo } & População estimada & \multicolumn{2}{c|}{ Indicação Clínica } \\
\hline $50-69$ & 289.383 & 88 & 49.704 \\
\hline $040-49$ & 228.898 & 275 & 23.603 \\
\hline Demais idades & 1.217 .750 & 166 & 7.761 \\
\hline Total & 1.736 .031 & 529 & 81.068 \\
\hline Realização em até 30 dias & ----------- & 517 & 72.785 \\
\hline Resultado em até 30 dias & ------------ & 475 & 73.851 \\
\hline Resultados em até 10 dias & ------------ & 191 & 52.435 \\
\hline
\end{tabular}

Fonte: Elaboração própria com base no DATASUS.

Considerando que apenas $1 \%$ da população feminina apresenta risco elevado para câncer de mama12, neste estudo observamos um percentual elevado de mulheres que realizaram mamografias com indicação de rastreio fora da faixa etária descrita. Tal procedimento resulta em exposição de maior número de mulheres à radiação ionizante e possíveis resultados falso-positivos associados ao rastreamento, sem que se alcancem os benefícios desejados na redução da mortalidade ${ }^{15}$. Outra consequência relacionada a este possível sobrediagnóstico é o aumento dos custos com sobretratamentos para o Sistema Único de Saúde.

No ano de 2019, o percentual das mamografias de rastreamento, com resultado liberado em até 30 dias após a realização do exame, foi superior às de mamografias por diagnóstico (91,10\% e 89,79\%, respectivamente). Embora existam parâmetros assistenciais estabelecidos na comparação entre o tempo para realização do exame de acordo com indicação clínica da mamografia (diagnóstico ou rastreio), espera-se um maior percentual de mamografias diagnósticas com resultados entregues em menos de 30 dias. Seria um reflexo da priorização de mulheres sintomáticas no agendamento/realização dos exames e, em consequência, na liberação dos laudos ${ }^{12}$. Porém, a proporção de mamografias de rastreio cujos resultados são liberados em até dez dias é de 64,68\% para 36,11\% das mamografias de diagnóstico (Tabela 3).

Tabela 03 - Distribuição da proporção de mamografias de rastreamento realizadas em 2019 segundo o tempo (em anos) de realização de mamografia anterior.

\begin{tabular}{|c|c|c|c|c|c|c|} 
Faixa etária & \multicolumn{6}{c|}{ Tempo } \\
& Mesmo ano & 1 ano & 2 anos & 3 anos & 4 ou mais & ignorado \\
\hline $40-49$ & $1,8 \%$ & $22,9 \%$ & $22,2 \%$ & $6,4 \%$ & $8,6 \%$ & $38,1 \%$ \\
\hline $50-69$ & $2,7 \%$ & $31,3 \%$ & $23,2 \%$ & $6,8 \%$ & $9,6 \%$ & $26,4 \%$ \\
\hline
\end{tabular}

Fonte: Elaboração própria com base no Sistema de Informações Ambulatoriais do SUS (SISCAN).

Com relação a periodicidade observa-se, na tabela 3, que cerca de 23\% (na faixa etária entre 40 e 49) e cerca de $31 \%$ (na faixa etária entre 50 e 69) dos exames mamográficos foram realizados com intervalo de um ano para a mamografia anterior, conforme recomenda a Federação Brasileira das Associações de Ginecologia e Obstetrícia (FEBRASGO). Enquanto 22\% (na faixa etária entre 40 e 49) e 23\% (na faixa etária entre 50 e 69) realizam o exame de forma bienal.

Com base nos dados do SIA/SUS, a Secretaria do estado estabeleceu que, em 2019, cada um de seus municípios deveria alcançar a meta de $76 \%$ de exames realizados, considerando a razão de mamografias 
de rastreio em mulheres de 50 a 69 anos pelo o total da população nesse mesmo grupo etário ${ }^{16}$. Entretanto somente quatro municípios alagoanos (Penedo, Pindoba, Marechal Deodoro e Maragogi) apresentaram valores superiores a meta estabelecida para ampliação dos diagnósticos precoces (Figura 2).

Figura 02 - Distribuição espacial das mamografias e razão de exames de rastreamento realizados em mulheres de 50 a 69 anos por município de residência em 2019.

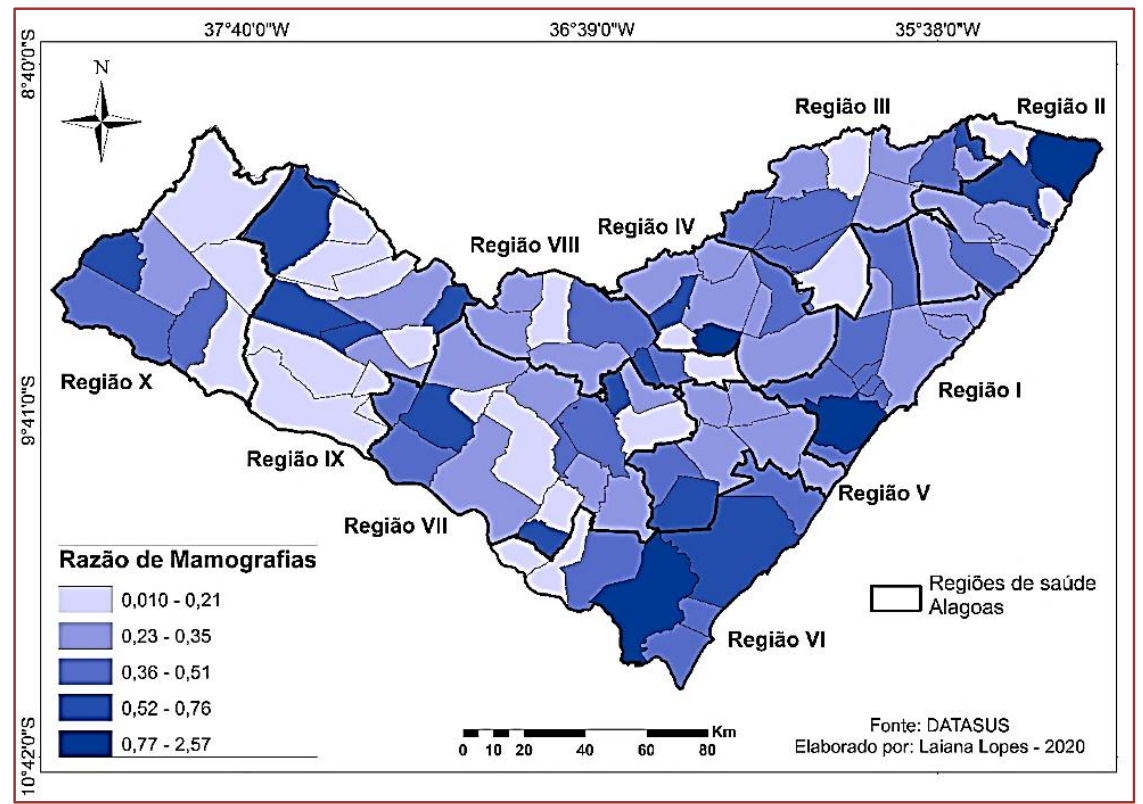

\section{DISCUSSÃo}

Neste estudo, os parâmetros assistenciais propostos pelo Ministério da Saúde foram correlacionados à distribuição dos mamógrafos em uso e à oferta do serviço de mamografia disponível no Sistema Único de Saúde (SUS) do estado de Alagoas. Apesar do sucessivo aumento no número de mamografias realizadas, a utilização da capacidade instalada de produção dos equipamentos mamógrafos não ultrapassou 35\% de seu potencial, em nenhum dos anos analisados, valor inferior ao encontrado em outros estados nordestinos, como Pernambuco, cuja utilização da capacidade instalada de produção dos mamógrafos se aproximou de $50 \%$ no ano de $2016^{17}$.

O número de mamografias estimadas como necessárias pelo MS tem como base as indicações clínicas dos exames de mulheres em duas faixas etárias ( 40 a 49 anos e 50 a 60 anos). No ano de 2019, o somatório das mamografias realizadas, por esses dois grupos etários, de todos os municípios alagoanos, totalizou 73.3670, que corresponde a somente 34\% do total de mamografias estimadas como necessárias.

Em contrapartida, o número de mamógrafos em funcionamento no mesmo ano ultrapassou em $22 \%$, o total estimado como necessário para atender a população alagoana. Assim, é evidente que a quantidade suficiente de mamógrafos disponíveis pelo serviço público de saúde não é garantia de que a meta de mamografias realizadas será alcançada. A mesma característica se estende a outras regiões brasileiras ${ }^{18}$.

As disparidades relacionadas ao acesso dos serviços públicos de mamografias dispostas nesse trabalho também foram identificadas em outros estudos nacionais, sejam: quanto ao grupo etário e indicação clínica; distribuição espacial irregular dos aparelhos, privilegiando municípios com melhores condições socioeconômicas; má qualidade da imagem impossibilitando a detecção das lesões em seu início; infraestrutura e profissionais qualificados, tanto para a realização do exame quanto para a interpretação e direcionamento das mulheres após o resultado; o formato oportunístico do rastreamento no Brasil (procura espontânea pelo serviço) em detrimento do rastreamento populacional (recrutamento ativo do público-alvo ${ }^{3,9,19}$. 0 rastreamento oportunístico surge como uma disparidade por ser menos efetivo quanto aos benefícios de redução da mortalidade e implicar mais custos ao sistema público de saúde. 
Segundo o Colégio Brasileiro de Radiologia (CBR) a mamografia com finalidade de rastreio, para detecção precoce do câncer de mama deve ser realizada anualmente em mulheres a partir dos 40 anos de idade 6 . Contudo para o Ministério da Saúde, a mamografia de rastreio deve ser realizada bianualmente em mulheres de 50 a 69 anos $^{19}$. A diferença entre o percentual de mulheres da primeira faixa etária (40 a 49 anos) e da segunda faixa etária (50 a 69 anos) que realizam o exame de mamografia para rastreio é de cerca de $1 \%$.

Quanto à distribuição espacial, rememoramos as contribuições do geógrafo Milton Santos ${ }^{20}$ ao afirmar que a regionalização dos serviços se trata de um processo de democratização. A regionalização adequada, considerando as variáveis de espaço e tempo propostas pelo Ministério da Saúde, evita a centralização dos mamógrafos e serviços oferecidos pelo sistema público de saúde, e facilita o acesso, acompanhamento e rastreamento dos diagnósticos pelo público-alvo, ainda que de forma oportunística. É importante ressaltar a necessidade da regionalização eficaz destes serviços juntamente com o fortalecimento do Programa Estratégia de Saúde da Família de forma a contribuir com programas de educação em saúde, e desta forma favorecer a conscientização da importância da realização da mamografia.

Em dezembro de 2019, dos 39 mamógrafos no estado de Alagoas, aproximadamente 41\% se encontravam em uso na capital de Maceió e 18\% em Arapiraca. A não regionalização também tende a sobrecarregar as regiões de saúde receptoras ${ }^{21}$. Assim, aponta-se que a maior e/ou menor distância entre o mamógrafo e a área de domicílio está diretamente relacionada à realização ou não do procedimento, consequentemente na detecção precoce e ao aumento ou redução dos índices de mortalidade por câncer de mama.

Destaca-se a necessidade de aprimorar o rastreamento do câncer de mama para população feminina, em Alagoas assegurando o acesso ao procedimento diagnóstico e acompanhamento adequado de forma equânime. As campanhas de divulgação/conscientização devem ser contínuas e atingir a população como um todo, seja urbana ou rural. Através do Programa Estratégia de Saúde da Família pode-se realizar fortalecimento/adequações no rastreamento realizado em Alagoas, ou até mesmo realizar a implantação de um rastreamento organizado.

Por fim, as limitações do presente estudo estão relacionadas principalmente à precisão dos dados fonte disponibilizados pelos sistemas e subsistemas do DATASUS. As limitações se configuram em desafios e, apesar de serem passíveis de gerar subnotificações, os dados oficiais são essenciais para subsidiar ações, planejamentos e programas voltados para diferentes neoplasias malignas em escala nacional e/ou regional.

\section{REFERÊNCIAS}

[1]. Organização Pan-Americana de Saúde [Internet]. Brasília: OPAS Brasil; 2018 [citado 2021 Fev 06]. Disponível em: https://www.paho.org/bra/index.php?option=com_content\&view=article\&id=5588:folha-informativacancer\&Itemid=1094\#: :text=As\%20causas\%20mais\%20 comuns\%20de,est $\%$ C3\%B4mago\%20(783\%20mil\%20mo rtes).

[2]. Instituto Nacional do Câncer. Estatísticas de câncer no Brasil [Internet]. Rio de Janeiro: INCA; 2020 [citado 2020 Fev 6]. Disponível em: https://www.inca.gov.br/numeros-de-cancer.

[3]. Oliveira EXG, Pinheiro RS, Melo ECP, Carvalho MS. Condicionantes socioeconômicos e geográficos do acesso à mamografia no Brasil, 2003-2008. Ciênc. saúde coletiva [Internet]. 2011 [citado 2020 jul 27]; 16(9): 3649-3664. Disponível em: http://www.scielo.br/scielo.php?script=sci_arttext\&pid=S1413-81232011001000002\&lng=en. https://doi.org/10.1590/S1413-81232011001000002.

[4]. Bezerra HS, Melo TFV, Barbosa JV, Feitosa EELC, Sousa LCM. Avaliação do acesso em mamografias no Brasil e indicadores socioeconômicos: um estudo espacial. Rev. Gaúcha Enferm. [Internet]. 2018 [citado 2021 ago 04]; 39 : e20180014. Disponível em: http://www.scielo.br/scielo.php?script=sci_arttext\&pid=S1983$14472018000100457 \& \operatorname{lng}=\mathrm{en}$.

[5]. Moura LVM, Sousa SS, Ferreira DMS, Oliveira RCS, Nascimento ABBL, Marques CPC. Avaliação da Cobertura do Exame Mamográfico de Rastreio do SUS e Mortalidade por Câncer de Mama no Nordeste brasileiro. Braz. J. Hea. Rev. [Internet] 2020 [citado $2020 \mathrm{dez} 02$ ]; 3(4):9533-9546. Disponível em: https://www.brazilianjournals.com/index.php/BJHR/article/view/14081.

[6]. Urban LABD, Chala LF, Bauab SP, Schaefer MB, Santos RP, Maranhão NMA et al. Recomendações do Colégio Brasileiro de Radiologia e Diagnóstico por Imagem, da Sociedade Brasileira de Mastologia e da Federação Brasileira das Associações de Ginecologia e Obstetrícia para o rastreamento do câncer de mama. Radiol Bras [Internet]. 2017 [citado 2020 ago 28]; 50(4): 244-249. Disponível em: http://www.scielo.br/scielo.php?script=sci_arttext\&pid=S010039842017000400244\&lng=en. http://dx.doi.org/10.1590/0100-3984.2017-0069. 
[7]. Instituto Nacional de Câncer. Confira as recomendações do Ministério da Saúde para o rastreamento do câncer de mama. [Internet]. Rio de Janeiro: INCA; 2019 [citado 2020 ago 6]. Disponível em: https://www.inca.gov.br/noticias/confira-recomendacoes-do-ministerio-da-saude-para-o-rastreamento-do-cancerde-

mama\#: :text=A\%20mamografia\%20de\%20rastreamento\%20\%E2\%80\%93\%20exame,existe\%20maior\%20incerte za\%20sobre\%20benef\%C3\%ADcios.

[8]. Instituto Brasileiro de Geografia e Estatística. Pesquisa Nacional de Saúde. Microdados [Internet]. 2013. Rio de Janeiro: IBGE; 2013 [citado 2020 nov 28]. Disponível em: http://www.ibge.gov.br/home/estatistica/populacao/pns/2013_vol3/default_microdados.shtm.

[9]. Amaral P, Luz L, Cardoso F, Freitas R. Distribuição espacial de equipamentos de mamografia no Brasil. Rev. Bras. Estud. Urbanos Reg. [Internet]. 2017 [citado 2020 ago 04]; 19(2): 326-341. Disponível em: http://www.redalyc.org/articulo.oa?id=513954272007.

[10]. Estado de Alagoas. Plano Diretor de Regionalização da Saúde de Alagoas [Internet]. Alagoas: Secretaria de Estado da Saúde. Superintendência de Planejamento e Participação Social; 2011 [citado 2020 nov 23]. Disponível em: http://docplayer.com.br/18913006-Plano-diretor-de-regionalizacao-da-saude-do-estado-de-alagoas-pdr-al-revisaono-ano-2011.html.

[11]. NERI, M. C. Qual foi o impacto da crise sobre a pobreza e a distribuição de renda? FGV Social, set. 2018.

[12]. Instituto Nacional de Câncer. Ficha técnica de indicadores relativos às ações de controle do câncer de mama [Internet]. Rio de Janeiro: INCA; 2014 [citado 2020 ago 6]. Disponível em https://www.inca.gov.br/sites/ufu.sti.inca.local/files//media/document//ficha-tecnica-indicadores-mama-2014.pdf.

[13]. Brasil. Ministério da Saúde. Secretaria de Atenção à Saúde. Departamento de Regulação, Avaliação e Controle de Sistemas Critérios e Parâmetros Assistenciais para o Planejamento e Programação de Ações e Serviços de Saúde no âmbito do Sistema Único de Saúde. Brasília: MS, 2017 [citado 2020 ago 6].

[14]. World Health Organization. Breast cancer now most common form of câncer: WHO taking action [Internet]. WHO; 2021 [citado 2021 fev 06]. Disponível em: https://www.who.int/news/item/03-02-2021-breast-cancer-nowmost-common-form-of-cancer-who-taking-action.

[15]. Instituto Nacional de Câncer. Diretrizes para a detecção precoce do câncer de mama no Brasil [Internet]. Rio de Janeiro: INCA; 2015 [citado 2020 ago 6]. Disponível em

https://www.inca.gov.br/sites/ufu.sti.inca.local/files//media/document//diretrizes_deteccao_precoce_cancer_mama _brasil.pdf.

[16]. Estado de Alagoas. Programa anual de saúde [Internet]. Alagoas: Secretaria de Estado da Saúde; 2019 [citado $2021 \mathrm{fev}$ 06]. Disponível em http://cidadao.saude.al.gov.br/transparencia/observatorios/observatorio-das-despesaspublicas-da-saude/monitoramento-da-saude/programacao-anual-de-saude-pas/.

[17]. Silva MTA, Silva Júnior VB, Mangueira JO, Gurgel Junior GD, Leal EMM. Distribuição dos mamógrafos e da oferta de mamografia em relação ao parâmetro assistencial do Sistema Único de Saúde em Pernambuco. Rev. Bras. Saúde Mater. Infant. [Internet]. 2018 [citado 2020 set 01]; 18(3):609-618. Disponível em: http://www.scielo.br/scielo.php?script=sci_arttext\&pid=S1519-38292018000300609\&lng=en https://doi.org/10.1590/1806-93042018000300009.

[18]. Silva RP, Gigante DP, Amorim MHC, Leite FMC. Fatores associados à realização de mamografia em usuárias da atenção primária à saúde em Vitória, Espírito Santo. Epidemiol. Serv. Saúde [Internet]. 2019 [citado 2020 jul 30]; 28(1): e2018048. Disponível em: http://www.scielo.br/scielo.php?script=sci_arttext\&pid=S223796222019000100307\&lng=en. https://doi.org/10.5123/s1679-49742019000100010.

[19]. Freitas JA, Oliveira BGPO, Santos RH, Ferreira HH, Santos RE. Análise do índice de cobertura da mamografia em mulheres entre 50 e 69 anos, por nível de ensino, segundo unidade de federação. Rev Med UFC. [Internet]. 2016 [citado 2020 ago 04]; 56(1): 14-17. Disponível em: http://www.revistademedicina.ufc.br/ojs/index.php/revistademedicinaufc/article/view/67.

[20]. SANTOS, Milton. Sociedade e Espaço: Formação Espacial como Teoriae como Método. In: SANTOS, Milton. Espaço e sociedade: Ensaios. 2ª ed. Petrópolis: Vozes, 1982.

[21]. Silva JGF, Santos GV, Nascimento IC, Souza JS, Santos JS. Distribuição dos equipamentos de TC e RM no estado de Alagoas. Braz. J. Hea. Rev. [Internet] 2020 [citado 2020 dez 02]; 3(5):13686-13695. Disponível em: https://www.brazilianjournals.com/index.php/BJHR/article/download/17529/14230. 


\section{Capítulo 14}

Reabilitação fisioterapêutica com o uso do kinect para tratamento de sequelas em pacientes com Acidente Vascular Encefálico - Revisão de literatura

\section{Carlos Eduardo de Almeida}

Dalvana Cristina de Carvalho Elesbão

Keila Carmen de Oliveira Silva Bassanelli

Marcela dos Santos Teixeira

Pedro Luiz Maruco dos Anjos

Ronaldo Paulo Merenda

Ana Carolina Ricardo Fernandes

Daniel Tineu Leite Maia

Resumo: 0 Acidente Vascular Encefálico (AVE) resulta na interrupção da irrigação sanguínea ao encéfalo, gerando lesão celular e déficit as funções neurológicas (O'SULLIVAN e SCHMITZ, 1993). Atualmente essa patologia é considerada uma das maiores causas de incapacidade e levando a uma diminuição na qualidade de vida. (RYERSON, 2004, PATEL et al. 2006). O AVE apresenta acometimentos como hemiparesia que é caracterizado pela perda parcial de força no hemicorpo contralateral ao da lesão cerebral, fraqueza muscular que diminui a função das unidades motoras e atrofia muscular pelo desuso.(ANDRREWS; BOHANNON,2000; OLNEY e RICHARDS,1996).0 presente artigo propõe uma revisão de literatura sobre o recurso tecnológico do Kinect na reabilitação em pacientes com sequelas de um AVE. 0 Kinect capta os movimentos dos pacientes por meio de câmeras dentro de um espaço específico transformando esses movimentos em comandos que proporcionam interação entre o jogo e o paciente. (SBC-Proceedings of SBGames 2012).

Palavras-chave: Acidente Vascular Encefálico, REABILITAÇÃO, FISIOTERAPIA, KINECT 


\section{INTRODUÇÃO}

O Acidente Vascular Encefálico (AVE) pode ser definido como uma restrição neurológica focal súbita em virtude de uma lesão vascular. Essa lesão inclui distúrbios de coagulação e hemodinâmicos, mesmo que não haja alterações em veias ou artérias. (André C. 2006). Sua incidência teve um aumento gradativo nos últimos 16 anos, sendo uma das maiores causas de morte em nosso país. (Lessa, I. 1999). As principais causas do AVE é descrita como hipertensão arterial sistólica ou diastólica, aumento do colesterol, diabetes, alcoolismo, sedentarismo, estresse, uso de anticoncepcionais orais.(McManus JA,Craig AMC, Langhrone P, Ellis G. Does, 2009).

As sequelas motoras predominantes são hemiplegia (ausência do movimento) e hemiparesia (diminuição do movimento) causada por lesão no neurônio superior, onde esses distúrbios levam a instabilidade postural ocasionando o desequilíbrio, afasia ou disartria, disfunção sensorial, visual, e o comprometimento mental e intelectual. (Resende FB, Viana CAP, Faria JLC. 2006/ Ottoboni C, Fontes SV, Fukujima MM. 2002).

A atuação da fisioterapia visa minimizar os efeitos deletérios do AVE por meio da utilização do game Kinect que apresenta jogos interativos para reabilitação da força muscular coordenação motora e equilíbrio como consequência a melhora funcional.

O objetivo desse artigo de revisão de literatura será demonstrar a importância da atuação fisioterapêutica juntamente com o uso do kinect evidenciando seus benefícios.

\section{METODOLOGIA}

Este estudo foi elaborado por meios de revisões sistemáticas dos últimos 16 anos, nas bases de dados Lilacs, Medline, Bireme e Pubmed. As palavras chave/descritores em saúde (DECs) utilizados foram: acidente vascular encefálico (AVE), fisioterapia, kinect, reabilitação. Foram encontrados 22 artigos e utilizados para o estudo um total de 10. Os excluídos se deram devido à ausência de dados e parâmetros nos experimentos.

\section{RESULTADOS}

Os resultados desse estudo foram baseados em indivíduos de ambos os sexos, portadores de sequelas de AVE. A amostra evidência, a reabilitação, os benefícios e os desafios propostos pelo kinect, como mostra a tabela abaixo:

\begin{tabular}{|l|l|l|}
\hline \multicolumn{1}{|c|}{ Reabilitação Virtual } & Dificuldades encontradas no inicio do tratamento & \multicolumn{1}{c|}{ Benefícios } \\
\hline Força Muscular & $\begin{array}{l}\text { Alguns jogos exigem movimentos multiarticulares } \\
\text { e grandes amplitudes }\end{array}$ & $\begin{array}{l}\text { Ganho de força muscular, } \\
\text { flexibilidade, amplitude de } \\
\text { movimento, resistência. }\end{array}$ \\
\hline Equilíbrio & $\begin{array}{l}\text { Consciência corporal, autoconfiança, melhoria na } \\
\text { marcha, prevenção de quedas. }\end{array}$ & $\begin{array}{l}\text { Hemiplegia, tonturas, alterações } \\
\text { visuais, riscos de quedas. }\end{array}$ \\
\hline Coordenação & $\begin{array}{l}\text { Cincinesia, presença de movimentos } \\
\text { involuntários, configuração anormal dos } \\
\text { membros, alteração cognitiva. }\end{array}$ & $\begin{array}{l}\text { Melhora da capacidade funcional, } \\
\text { qualidade nos movimentos finos e } \\
\text { amplos, agilidade. }\end{array}$ \\
\hline
\end{tabular}




\section{DISCUSSÃO}

As disfunções do Acidente Vascular Encefálico podem ser permanentes ou recuperáveis, como a hemiplegia, disfunções na marcha, alterações do equilíbrio, força muscular, aumento do risco de quedas. (Chen SD, Yang DI, Lin TK, Shaw FZ, Liou CW, Chuang, 2011/ Rose DZ, Kasner SE, 2011).

0 uso do kinect incentiva as funções motoras grosseiras e finas, através de uma interação do individuo com o ambiente virtual. Essa interação traz benefícios por meio de sua capacidade de manter o controle entre a realidade e o abstrato, que proporciona ao usuário a aprender coisas fora dos métodos tradicionais. (Lambercy O, Dovat L, Yun H, Wee SK, Kuah CW, Chua KS, 2011).

Para Bompa [2002], o tratamento utilizando Kinect interfere nas capacidades biomotoras as quais estão associadas com força, velocidade, resistência, coordenação, flexibilidade e equilíbrio.

A terapia por meio de uma realidade virtual (Kinect) proporciona movimentos induzidos resultando no mecanismo de neuroplasticidade que favorece a reorganização cortical, demonstrando fisiologicamente a melhora do desempenho do equilíbrio corporal, tendo como resultado de um feedback extrínseco. (Jang et al, 2005).

Segundo pesquisadores foi constatado que o uso do game Kinect através dos movimentos dos usuários, permite o rastreamento e identificação de suas articulações por meio de um sensor onde a imagem é processada, motivando os indivíduos na realização dos movimentos proporcionando ganhos significativos no controle do equilíbrio corporal, melhora no desempenho motor, mudanças positivas relacionadas à marcha.

\section{CONCLUSÃO}

Pode-se afirmar que a intervenção fisioterapêutica com o uso do Kinect auxilia e traz benefícios motivacionais, lúdicos e interativos, possibilitando liberdade de movimento, aliviando o estresse e mudando a rotina do tratamento fisioterapêutico tradicional. Conclui-se que mesmo com os resultados positivos com o uso do kinect é indispensável o acompanhamento e avaliação constante de um fisioterapeuta onde irá traçar estratégias de reabilitação pertinentes a cada individuo.

\section{REFERÊNCIAS}

[1] ANDREWS, A.; Bohannon, R. Distribution of muscle strength impairments following stroke. Clin Rehabil. v.14, p.79-87, 2000.

[2] ANDRÉ C. Manual de AVC. 2ª̣ed. Rio de Janeiro Revinter; 2006.

[3] BOMPA, T. O., 2002. PERIODIZAÇÃO: TEORIA E METODOLOGIA DO TREINAMENTO. 4. ED. SÃO PAULO: PHORTE

[4] CHEN SD, Yang DI, Lin TK, Shaw FZ, Liou CW, Chuang YC. Roles of Oxidative Stress, Apoptosis, PGC-1 $\alpha$ and Mitochondrial Biogenesis in Cerebral Ischemia. Int J Mol Sci. 2011; 12(10): 7199-215.

[5] JANG SH, et al. Cortical reorganization and associated functional motor recovery after virtual reality in patients with chronic stroke: an experimenter-blind preliminary study. Arch Phys Med Rehabil. 2005.

[6] LAMBERCY O, Dovat L, Yun H, Wee SK, Kuah CW, Chua KS, et al. Effects of a robot-assisted training of grasp and pronation/supination in chronic stroke: a pilot study. J Neuroeng Rehabil. 2011; 8:63.

[7] LESSA, I. Epidemiologia das doenças cerebrovasculares no Brasil. Rev. Soc. Cardiol. Estado de São Paulo. v. 4, p. $509-18,1999$.

[8] MCMANUS JA, Craig AMC, Langhorne P, Ellis G. Does behaviour modification affect post-stroke risk factor control? Three-year follow-up of a randomized controlled trial. Clinical Rehabil. 2009; 23(2): 99-105.

[9] OTTOBONI C, Fontes SV, Fukujima MM. Estudo comparativo entre marcha normal e a de pacientes hemiparéticos por acidente vascular encefálico: aspectos biomecânicos. Rev Neurociências. 2002; 10(1): 10-6.

[10] O'SULLIVAN, S.B.; SCHMITZ T.J. Avaliação e tratamento. 2ª̣ed. São Paulo: Manole; 1993, p.385.

[11] OLNEY, S.; RICHARDS, C. Hemiparetic gait following stroke. Part I: Characteristics. Gait and Posture, Amsterdam, v. 4, p.136-148, 1996.

[12] PATEL, M.D.; TILLING, K.; LAWRENCE, E.; RUDD, A.G.; WOLFE, C.D .A.; MCKEVITT, C.D. Relationships between long-term stroke disability, handicap and health-related quality of life. Age and Ageing. v. 35, p.273-9, 2006. 
[13] RYERSON, S.D. Hemiplegia. In: Umphred DA (editor). Reabilitação Neurológica. 4⿳ạ. ed. Barueri: Manole 2004, p.782-830.

[14] RESENDE FB, Viana CAP, Faria JLC. Análise da hiper--extensão de joelho em pacientes hemiparéticos usando órtese para neutralização da flexão plantar.Rev Neurociências. 2006; 14(3): 140-3. 


\section{Capítulo 15}

Síntese e caracterização de policátions bioresponsivos com potencial de aplicações no carregamento de genes

\section{Paulo Cesar Rodrigues}

Resumo: Quitosana é um dos principais polímeros usados para terapia genica devido a sua boa biocompatibilidade, baixa toxicidade e por ser facilmente modificável (LAYEK; SINGH, 2012, 2013). Os polímeros adquiridos foram purificados, substituídos com DIPEA e então peguilados e então caracterizados por RMN H1, GPC, grau de ionização, capacidade de tamponamento além de sorção de água. Os poliplexos feitos por coacervação foram testados por eletroforese e conduziu-se estudo de citotoxicidade. A substituição por DIPEA resultou em polímero de $54 \%$ de substituição e ocasionou uma ligeira modificação em sua massa molecular, além disso demostrou-se maior capacidade de tamponamento dentro da faixa de $\mathrm{pH}$ fisiológico. A sorção de água demostrou que os polímeros com PEG retiveram mais água, isso se devo ao fato de o PEG reter estéricamente moléculas de águas próximas. Os estudos de eletroforese mostraram que o polímero peguilado foi menos capaz de reter o siRNA em baixas razões de carga devido ao prolongamento lateral das cadeias. Estudo de citotoxicidade demonstrou que mesmo os polímeros modificados não provocou alterações significativas de toxicidade quando comparados ao controle. Conclui-se que modificações sobre a quitosana com DIPEA e PEG são capazes de modificar sua capacidade de complexar siRNA, sem que sua toxicidade seja alterada. 


\section{INTRODUÇÃO}

A quitosana destaca-se dentre os carreadores não virais para entrega gênica, pois apresenta baixa citotoxicidade e excelente biocompatibilidade e biodegradabilidade e permite alterações químicas com facilidade, além de representar uma escolha mais segura diante dos vetores virais, pois, embora estes apresentem alta eficiência de trasfecção e um amplo espectro de alvos celulares, eles podem gerar respostas imunológicas indesejadas e/ou apresentarem efeitos carcinogênicos que restringem seu uso (LAYEK; SINGH, 2013; LAYEK; SINGH, 2012).

As aminas primarias presentes na quitosana quando em $\mathrm{pH}$ baixo, inferior a 6,5, tornam-se positivamente carregadas e interagem, por meio de interação eletroestática, com os grupos fosfatos dos ácidos nucleicos formando poliplexos capazes de protege-los da degradação lisossomo e durante a biodistrubuilção (LAYEK; SINGH, 2012; CHANG et al., 2010; HUANG et al., 2005; KÖPING-HÖGGÅRD et al., 2004 ---- ).

Os polímeros catiônicos por serem de fácil manipulação e produção, permite variar sua estrutura química e massa molecular oferecendo uma alta versatilidade aos poliplexos formados, então sua grande utilização para entrega gênica, além de interagir fortemente com o DNA/siRNA, de forma não covalente.

Pequeno RNA de interferência (siRNA) são pequenos fragmentos de RNA capazes de silenciar genes pelo processo de interferência de RNA (RNAi). O siRNA é capaz de se associar ao RNA mensageiro (RNAm) e induzirem sua degradação, esta capacidade abre uma nova modalidade para o tratamento de doenças (BALLARÍN-GONZÁLEZ; HOWARD, 2012).

A trasfecção é mais eficiente em meio ácido, pois possui um alto grau de ionização neste $\mathrm{pH}$, o que é um empecilho, uma vez que o $\mathrm{pH}$ do sangue está na faixa de 7,2 a 7,4, porém a inserção de aminas terceirariaspermite variar o grau de ionização e aumentar a capacidade tamponante . 0 uso de cadeias de polietileno glicol (PEG) permite aumentar a solubilidade em água e são capazes de prevenir a sorção de proteínas (TIERA et al., 2006).

Um estudo que vem sendo desenvolvido pelo grupo do Laboratório de Biomateriais e Nanotecnologia (IBILCE-UNESP) indica que ocorre a formação de nanopartículas coloidalmente estáveis (até 24 horas) com diâmetro em torno de $200 \mathrm{~nm}$, quando um derivado de quitosana de $90 \mathrm{kDa}$, contendo aproximadamente $50 \%$ de substituição com N, N-Diisopropiletilamina (DIPEA), interage com siRNA. Porém, a peguilação deste derivado reduziu sua capacidade de complexar o ácido nucleico, originando partículas de mesmo diâmetro em maiores razões de carga, conhecida na literatura como razão N/P (amina/fosfato). Em trabalho recente, o mesmo grupo também mostrou que, sob a mesma composição de amina terciária, derivados de quitosana com massa molecular maior possuem uma maior capacidade de complexar o siRNA (SOUZA et al., 2018).

Assim, nesse estudo, será sintetizado um derivado de quitosana com elevada massa molecular e composição de DIPEA próxima a 50\%, que posteriormente será substituído com crescentes proporções de PEG (1-10\%) de 2 kDa via ligação dissulfeto, para avaliação de seus efeitos no polímero e nos poliplexos.

\section{OBJETIVOS}

O objetivo principal é a síntese de policátions biorresponsivos para formação de poliplexos com o RNA de interferência, visando ampliar a capacidade de complexação do siRNA e a estabilidade dos poliplexos formados sob baixa razão de cargas (razão N/P). Para realização deste objetivo, compreende-se as seguintes etapas:

I) Síntese e caracterização do derivado com DIPEA (Ch-DIPEA), com avaliação do efeito do substituinte nas propriedades físico-químicas do derivado em relação a quitosana (CH).

II) Peguilação do derivado Ch-DIPEA, com avaliação da influência do grau de peguilação (1 a $10 \%)$ nas propriedades físico-químicas dos policátions.

III) Preparação e caracterização de poliplexos com RNA de interferência (siRNA)

IV) Estudo de citotoxicidade dos polímeros e poliplexos 


\section{MATERIAL E MÉTODOS}

\subsection{MATERIAIS E INSTRUMENTOS}

\subsubsection{MATERIAIS}

A quitosana, a Agarose, o brometo de etídio, o complexo antibiótico, meio de cultura celular de Eagle modificado com Dulbecco, o soro fetal bovino, o 0-(2-mercaptoetil) -O'-metil-polietilenoglicol (PEG-SH), o $\mathrm{N}$, N-Diisopropiletilamina (DIPEA) e a membrana de dialise de 14kDa foram adquiridos da Sigma-Aldrich. Os ácidos acético e clorídrico, os fosfatos de sódio e potássio, os hidróxidos de sódio e amônio foram adquiridos da Dinâmica. Os cloretos de sódio e potássio foram adquiridos da Synth. O cloreto de deutério e água deuterada foram adquiridos da Aldrich Chemical Co. Os ensaios de citotoxicidade foram realizados utilizando o kit CellTiter96® AQueous One Solution (Promega Corporation).

\subsubsection{INSTRUMENTOS}

A Cromatografia de Permeação em Gel (GPC) foi realizada em HPLC Shimadzu LC-20A com detector de índice de refração Shimadzu RDI-10a․ A Ressonância Magnética Nuclear (RMN) de hidrogênio $\left(\mathrm{H}^{1}\right)$ foram realizadas em foram realizadas em um Espectrômetro de Ressonância Magnética Nuclear de $400 \mathrm{MHz}$ da Bruker. As medidas de pH foram realizadas em medidor de pH Hanna HI 2211. As eletroforeses foram realizadas em cuba Horizon ${ }^{\circledR}$. As amostras foram liofilizadas em no Liofilizador L101 da LIOTOP. Toda água deionizada utilizada foi purificada em sistema Gehaka.

\subsection{PURIFICAÇÃO E SÍNTESE DOS POLÍMEROS}

\subsubsection{PURIFICAÇÃO DA QUITOSANA}

A purificação foi realizada conforme descrito por Wu et al., 2016. Desta forma, $15 \mathrm{~g}$ de quitosana de alta massa molecular foi dissolvida em 2,250 l de solução de ácido acético $1 \%(\mathrm{v} / \mathrm{v})$ e 0,750 l de água deionizada, filtrado em papel de filtro quantitativo $(11 \mu \mathrm{m})$, então precipitada com uma solução de hidróxido de amônia $2 \%$ (v/v) e filtrados novamente. 0 precipitado foi lavado com água de deionizada e posto em diálise contra água deionizada até que o $\mathrm{pH}$ da solução fique próximo de 7 . A amostra foi então liofilizada.

\subsubsection{SUBSTITUIÇÃO COM DIPEA}

Uma massa de 1,5 g de quitosana foi dissolvida em quantidade estequiométrica de ácido clorídrico 0,065 mol l-11, após o acréscimo de $20 \mathrm{ml}$ de água, a solução foi mantida em agitação até a completa solubilização. Então a solução foi então aquecida a $70{ }^{\circ} \mathrm{C}$ em sistema de refluxo e o pH foi ajustado para 12 usando solução de hidróxido de sódio $5 \mathrm{~mol} \mathrm{l}^{-1}$. Uma massa de 1,7 g de DIPEA foi transferido para o sistema e o $\mathrm{pH}$ novamente ajustado para 12 , a reação foi mantida por 90 minutos com ajustes de $\mathrm{pH}$ a cada 10 minutos. A amostra foi então transferida para membranas de diálise de $14 \mathrm{kDa}$ e mantido contra solução de $\mathrm{NaOH}$ $0,05 \mathrm{~mol} \mathrm{l}^{-1}$ nas primeiras 20 horas e então contra água até que o $\mathrm{pH}$ estivesse neutro, com trocas diárias de solvente. 0 derivado foi recuperado por liofilização.

\subsubsection{MODIFICAÇÃO COM PEG}

Uma massa de 0,34 g de quitosana substituída por DIPEA foi solubilizado em $20 \mathrm{ml}$ solução de ácido acético $0,03 \mathrm{~mol} \mathrm{l}^{-1} \mathrm{e}$ mantido sob agitação por 4 dias. Adicionou-se $14 \mathrm{ml}$ de tampão fosfato-salino (PBS) ao sistema e o pH deste foi ajustado com solução de hidróxido de sódio $5 \mathrm{~mol} \mathrm{l}^{-1}$ para 7,4. Sequencialmente 5,1 mg de éster N-hidroxissuccinimida do ácido 3-(2-piridilditio) propiônico (SPDP) solubilizado em $1 \mathrm{ml}$ de dimetilsulfóxido (DMSO) e mantido sob agitação por 3 horas em sistema de aquecimento $40^{\circ} \mathrm{C}$. Então 28,8 mg de 0-(2-mercaptoetil)-O'-metil-polietilenoglicol (PEG-SH) solubilizado em 1 ml de tampão PBS pH 7,4 foi adicionado ao sistema e este foi mantido sob agitação a $40{ }^{\circ} \mathrm{C}$ por 16 horas. A solução foi então mantida em dialise contra PBS por 4 dias e então contra $\mathrm{NaOH}$ até que o pH estivesse entre 8-9. Recuperou-se a amostra por liofilização. 
Figura 1 - Estrutura geral dos polímeros propostos com indicação dos substituintes, DIPEA (verde) e polietileno glicol (azul) incorporado via ligação dissulfeto (vermelho)

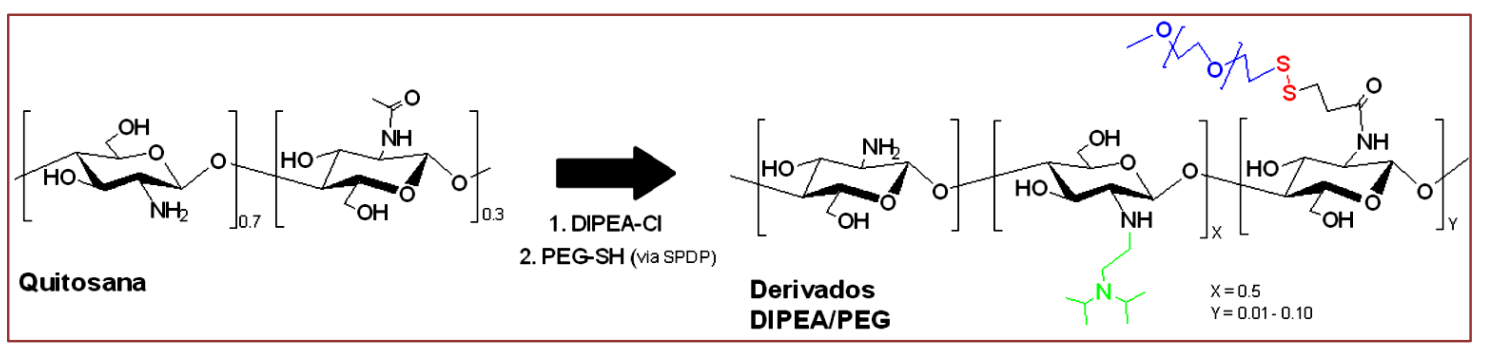

\subsection{CARACTERIZAÇÃO DOS POLÍMEROS}

\subsubsection{RESSONÂNCIA MAGNÉTICA NUCLEAR (RMN) DE HIDROGÊNIO (H1)}

Amostras de aproximadamente $5 \mathrm{mg}$ de quitosana e seus derivados foram dissolvidas em $700 \mu \mathrm{l}$ de água deuterada e $20 \mu \mathrm{l}$ de cloreto de deutério. Os espectros de RMN ${ }^{1} \mathrm{H}$ foram realizados no Instituto de Química de São Carlos (IQSC-USP), num espectrômetro Agilent Tecnologies de $400 \mathrm{MHz}$ à temperatura de $70^{\circ} \mathrm{C}$ e sem supressão de água.

0 grau de acetilação (GA) foi calculado comparando-se a área integrada dos três hidrogênios metílicos do grupo acetamida $\left(I_{\mathrm{CH}_{3}}\right)$, com a área dos hidrogênios ligados ao carbono anomérico $\left(I_{H^{*}}\right)$, utilizando a equação 1:

$$
G A=\left[\frac{I_{C H 3}}{3 I_{H^{*}}}\right] * 100 \quad \text { Equação } 1
$$

O grau de substituição pelos grupos DIPEA foi determinado pela razão da área dos seus doze hidrogênios metílicos $\left(I_{\text {metílicos }}\right)$ do substituinte com a área dos hidrogênios anomérico.

$$
\text { G.S. } \text { DIPEA }=\left[\frac{I_{\text {metilicos }}}{12 I_{H^{*}}}\right] * 100 \quad \text { Equação } 2
$$

O grau de peguilação foi determinado pela área dos cento e setenta e dois hidrogênios metílenicos de repetição presentes na cadeia do PEG ( $\left.A_{\text {metílenicos }}\right)$ e pela área dos hidrogênios anomérico.

$$
\text { G.S.PEG }=\left[\frac{A_{\text {metienicos }}}{172 I_{H^{*}}}\right] * 100 \quad \text { Equação } 3
$$

\subsubsection{CROMATOGRAFIA DE PERMEAÇÃO EM GEL (GPC)}

As medidas foram tomadas em cromatógrafo Shimadzu (LC-20), com detecção por índice de refração modelo RID-10 a do Laboratório de Fotoquímica do Departamento de Físico-Química do Instituto de Química de São Carlos. Na análise empregou-se como eluente a solução tamponante ácido acético/acetato de sódio de $\mathrm{pH} 4,5$, o fluxo foi de $0,8 \mathrm{ml} /$ minuto com temperatura de $35^{\circ} \mathrm{C}$. A concentração das amostras injetadas no cromatógrafo foi $5 \mathrm{~g} \mathrm{l}^{-1}$ solubilizadas também em solução tamponante de $\mathrm{pH} 4,5$. A curva de calibração das colunas foi construída a partir da injeção com soluções padrão monodispersas Pullulan de Mw 805.000 a 6.200 Da.

\subsubsection{CAPACIDADE DE TAMPONAMENTO (CT) E GRAU DE IONIZAÇÃO (GI)}

Ambos os parâmetros foram determinados a partir do mesmo procedimento. Uma massa de polímeros contendo 2,37·10-4 mols de amina foi solubilizada em $40 \mathrm{ml}$ de solução de ácido clorídrico $0,01 \mathrm{~mol} \mathrm{l}^{-1} \mathrm{com}$ força iônica ajustada com a adição de 0,33 g de cloreto de sódio, tal sistema permaneceu em agitação para 


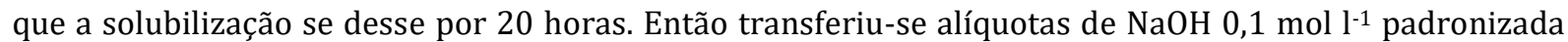
sobre o sistema e o pH após a adição determinado. Com os dados uma curva de pH pelo volume de $\mathrm{NaOH}$ usado foi criada, desta se determinou a curva sua primeira derivada a fim de evidenciar os pontos inicial e final da titulação.

O grau de ionização (GI) foi determinado entre o ponto final e inicial determinados pela curva de titulação determinado pela equação 2 :

$$
G I=\left[1-\frac{V_{x}-V_{i}}{V_{f}-V_{i}}\right] \times 100 \quad \text { Equação } 4
$$

Sendo $V_{\mathrm{x}}$ o volume ao qual se pretende determinar, $\mathrm{V}_{\mathrm{i}}$ o volume inicial determinado pela primeira inflexão e $V_{\mathrm{f}} \mathrm{o}$ volume final determinado pela última inflexão. A capacidade de tamponamento é representada pela própria curva de titulação.

\subsubsection{SORÇÃO DE ÁGUA}

Para este estudo uma massa aproximada de $20 \mathrm{mg}$ dos polímeros previamente secos em estufa foram mantidos em dessecador com humidade relativa de $100 \%$ em água por 48 horas a temperatura constante de $21{ }^{\circ} \mathrm{C}$, em seguida as massas foram novamente mensuradas. A sorção de água $\left(\mathrm{S}_{\mathrm{H} 20}\right)$ foi determinada pela equação 3:

$$
S_{H 2 O}=\left[\frac{m_{f}-m_{i}}{m_{i}}\right] \times 100 \quad \text { Equação } 5
$$

Onde $m_{\mathrm{f}}$ indica a massa final do experimento e $\mathrm{m}_{\mathrm{i}}$ a massa inicial de cada polímero.

\subsection{PREPARAÇÃO E CARACTERIZAÇÃO DOS POLIPLEXOS}

\subsubsection{FORMAÇÃO DOS POLIPLEXOS}

Os poliplexos foram formados pelo método de complexação simples. Amostras de 2 a $4 \mathrm{mg}$ foram solubilizadas em $200 \mu \mathrm{l}$ de $\mathrm{HCl} \mathrm{0,1} \mathrm{mol} \mathrm{l-1} \mathrm{e} \mathrm{após} \mathrm{período} \mathrm{de} 20$ horas em agitação uma alíquota de 1,8 ml de tampão fosfato de pH ajustado em 7,4 foi adicionado ao sistema. Variações da razão amina/fosfato (N/P) foram criadas mantendo o valor molar de nitrogênio presente nos grupos aminas da quitosana e variando a quantidade de fósforo presente nos grupos fosfatos do siRNA, após a mistura esta foi mantida em baixa rotação orbital por cerca de 30 minutos.

\subsubsection{ELETROFORESE}

Uma quantidade de siRNA fixa de 1,25 $\mu$ g foram empregadas neste estudo, o volume da solução estoque dos poliplexos em $21 \mu \mathrm{l}$, sendo que $4 \mu \mathrm{l}$ de azul de bromofenol foram adicionados imediatamente após a estabilização dos poliplexos. Em seguida, $10 \mu \mathrm{l}$ da solução de poliplexos foram aplicados em gel de agarose $0,8 \%(\mathrm{~m} / \mathrm{v})$ feito por meio da dissolução de agarose em tampão TAE 1X. Na constituição do gel de agarose foi empregado brometo de etídeo, de modo que sua concentração no gel fosse $0,004 \%(\mathrm{~m} / \mathrm{m})$ em relação à agarose. As razões N/P estudadas foram 0, 1, 2, 3, 5, 7 e 10. Na corrida aplicou-se uma diferença de potencial de 80 volts por 1 hora e 20 minutos. Como condutor elétrico foi usado o tampão TAE 1X. Por fim, o gel foi revelado em transiluminador UV, no Laboratório de Hemoglobinas e Genética das Doenças Hematológicas (LHGDH), do IBILCE/UNESP. 


\subsection{CITOTOXICIDADE}

A viabilidade celular na presença dos polímeros foi determinada com o kit comercial de proliferação celular CellTiter96 ${ }^{\circledR}$ AQueous One Solution (Promega Corporation), composto de 3-(4,5-dimetiltiazol-2-il)-5(3-carboximetóxifenil)-2-(4-sulfofenil)-2H-tetrazólio (MTS) e etossulfato de fenazina (PES). As células utilizadas no ensaio foram macrófagos da linhagem RAW 264.7. Aproximadamente $5 \mathrm{mg}$ de polímero foram solubilizados em $0,2 \mathrm{ml}$ de $\mathrm{HCl} 0,1 \mathrm{~mol} \mathrm{l}^{-1}$ seguido da adição de $1,8 \mathrm{ml}$ de meio completo, então aplicados sobre as células em diferentes concentrações $\left(0,02 ; 0,05 ; 0,1 ; 0,2\right.$ e $\left.0,5 \mathrm{~g} \mathrm{l}^{-1}\right)$. Também foi determinada a viabilidade celular na presença dos poliplexos nas diferentes razões N/P $(1 ; 5 ; 10 ; 20$ e 50). Como controle negativo para viabilidade, foi utilizado uma solução de dodecil sulfato de sódio (SDS) 3\%, e células não tratadas como controle positivo.

\section{RESULTADOS E DISCUSSÔES}

\subsection{CARACTERIZAÇÃO DOS POLÍMEROS}

\subsubsection{RMN H ${ }^{1}$}

Os hidrogênios dos carbonos anomérico apresentaram sinal de deslocamento químico entre 5,12 e 5,44 ppm. Os hidrogênios do grupo acetamida apresentam o sinal na região entre 2,2 e $2,4 \mathrm{ppm}$. A partir da equação 1 é possível determinar o grau de acetilação sobre a quitosana determinou-se o G.A. como sendo $25 \%$, como ilustrado pela figura 2 .

A adição do grupo DIPEA modifica o espectro de emissão do polímero dando origem a um novo sinal na região entre 1,5 a $1,9 \mathrm{ppm}$ em especial um intenso pico em 1,7 ppm que corresponde aos hidrogênios metílicos dos grupos isopropil pela equação 2, obtive-se que o valor de substituição foi de 53,7\%.

Após a peguilação um novo sinal foi originado em 3,9 ppm que corresponde aos hidrogênios das repetições da cadeia de PEG, calculando a porcentagem de substituição por PEG pela equação 3 tem-se que esta foi de $1,1 \%$.

\subsubsection{GPC}

A massa molecular $\left(\mathrm{M}_{\mathrm{w}}\right)$ é de extrema importância para a construção de vetores na terapia genica não viral, pois esta está diretamente relacionada ao tamanho da cadeia do polímero e o tamanho da nanopartícula formada por ele. A técnica de GPC é muito empregada na determinação de massas de polímeros naturais e sintéticos, pois consiste na separação destas moléculas por seu raio hidrodinâmico. A Tabela 1 exprime os dados obtidos pela analises dos polímeros sintetizados.

Tabela 1 - Propriedades da quitosana e seu derivado.

\begin{tabular}{|c|c|c|c|}
\hline Amostra & Grau de substituição (\%) & \multicolumn{1}{c|}{$\begin{array}{c}\mathrm{M}_{\mathrm{w}} \\
(\mathrm{g} / \mathrm{mol})\end{array}$} & $\frac{M_{w}}{M_{n}}$ \\
\hline Quitosana & - & 294,472 & 1,20354 \\
\hline Ch-DIPEA & 54 & 283,408 & 2,12851 \\
\hline
\end{tabular}

\subsubsection{CAPACIDADE DE TAMPONAMENTO (CT)}

Após a internalização celular, já em meio endossomal os polímeros se protonam gerando um fluxo de prótons para o interior do endossomo, numa tentativa de restaurar o $\mathrm{pH}$, comitantemente o influxo dos contraíons desestabiliza o controle osmótico ocasionando o rompimento da membrana endossomática (CAO et al., 2019). A capacidade do vetor como aceptor de prótons dentro da faixa de $\mathrm{pH}$ endossomal é de grande importância para a eficiente liberação do siRNA. A figura 3 compreende as curvas de titulação para os polímeros de quitosana e para o polímero de quitosana substituído por DIPEA. 
Figura 2 - Espectro de RMN H ${ }^{1}$ de quitosana e dos derivados.

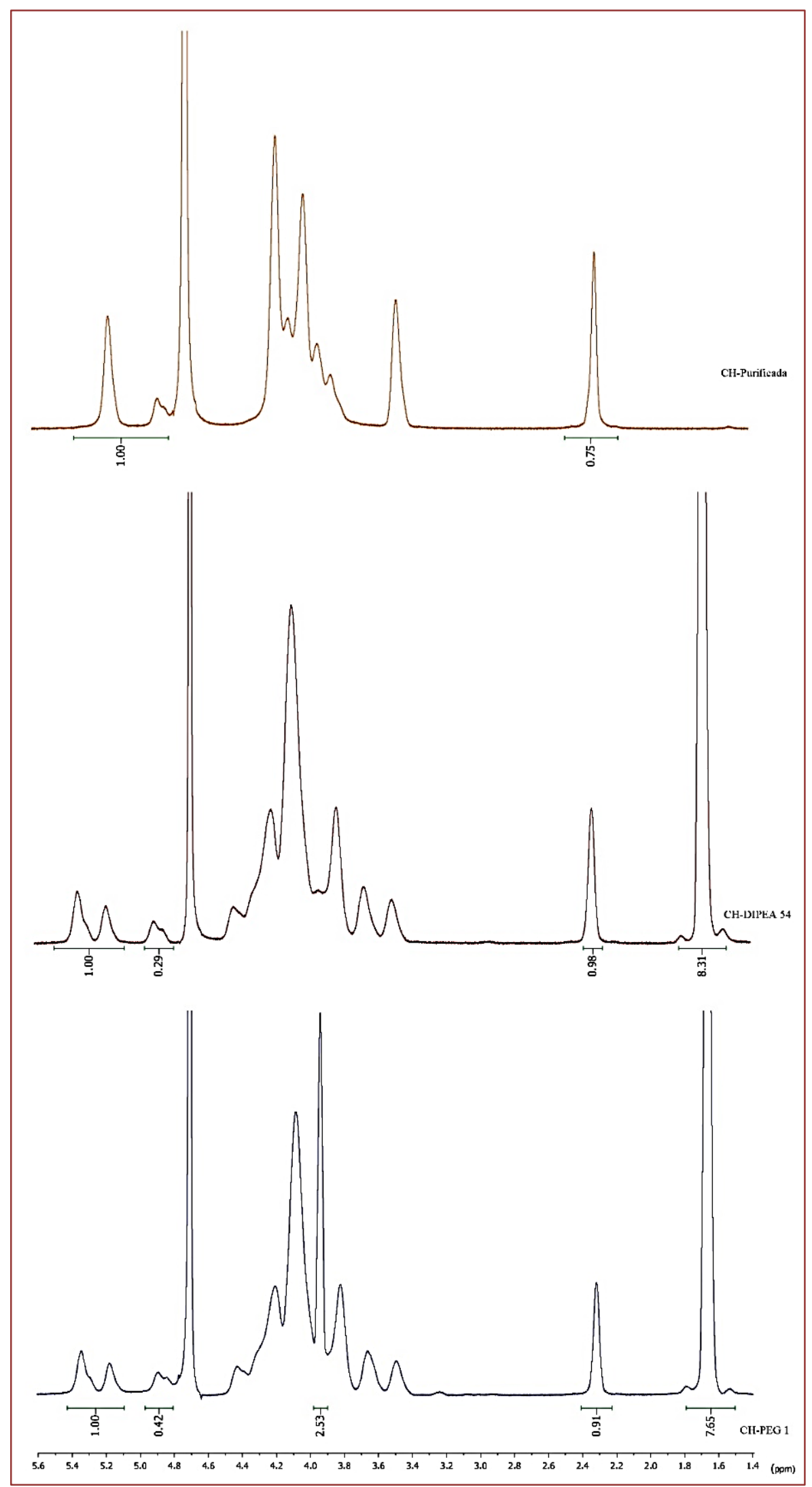


Figura 3 - Curva de titulação do polímero de quitosana (direita) e substituído por DIPEA (esquerda).

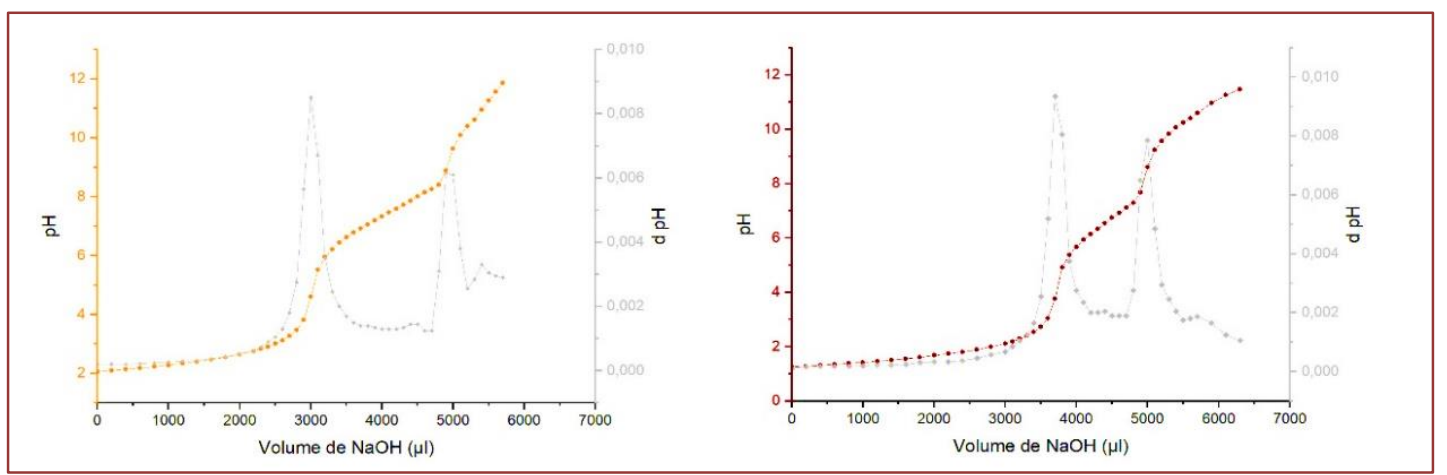

O polímero substituído por DIPEA demostra maior capacidade de tamponamento dentro da faixa desejada, essa melhor capacidade está associada a presença dos grupos aminas cujos pKa encontra-se próxima o pH fisiológico e o endossomal melhorando sua solubilidade no primeiro e funcionando como base de Brønsted-Lowry no segundo.

\subsubsection{GRAU DE IONIZAÇÃO (GI)}

O grau de ionização dos polímeros é influenciado pela quantidade de aminas secundarias e terceirais presentes em sua estrutura. A adição do agrupamento DIPEA modifica o perfil de ionização deste, faixa de pKa destas aminas. A figura 4 ilustra o perfil do grau de ionização para cada uma das espécies analisadas.

\subsubsection{SORÇÃO DE ÁGUA}

A formação de uma camada de água no entorno dos polímeros peguilados é tido como principal mecanismo que impede a interação dos poliplexos com proteínas séricas em meio fisiológico (ELSABAHY; WOOLEY, 2012). O ensaio consistiu na análise gravimétrica de água após a exposição dos polímeros a atmosfera controlada rica em água com temperatura constante de $21{ }^{\circ} \mathrm{C}$ de forma que a umidade máxima do ar estivesse próxima a 1,5\% $(\mathrm{v} / \mathrm{v})$.

Figura 4 - Grau de ionização em função do pH

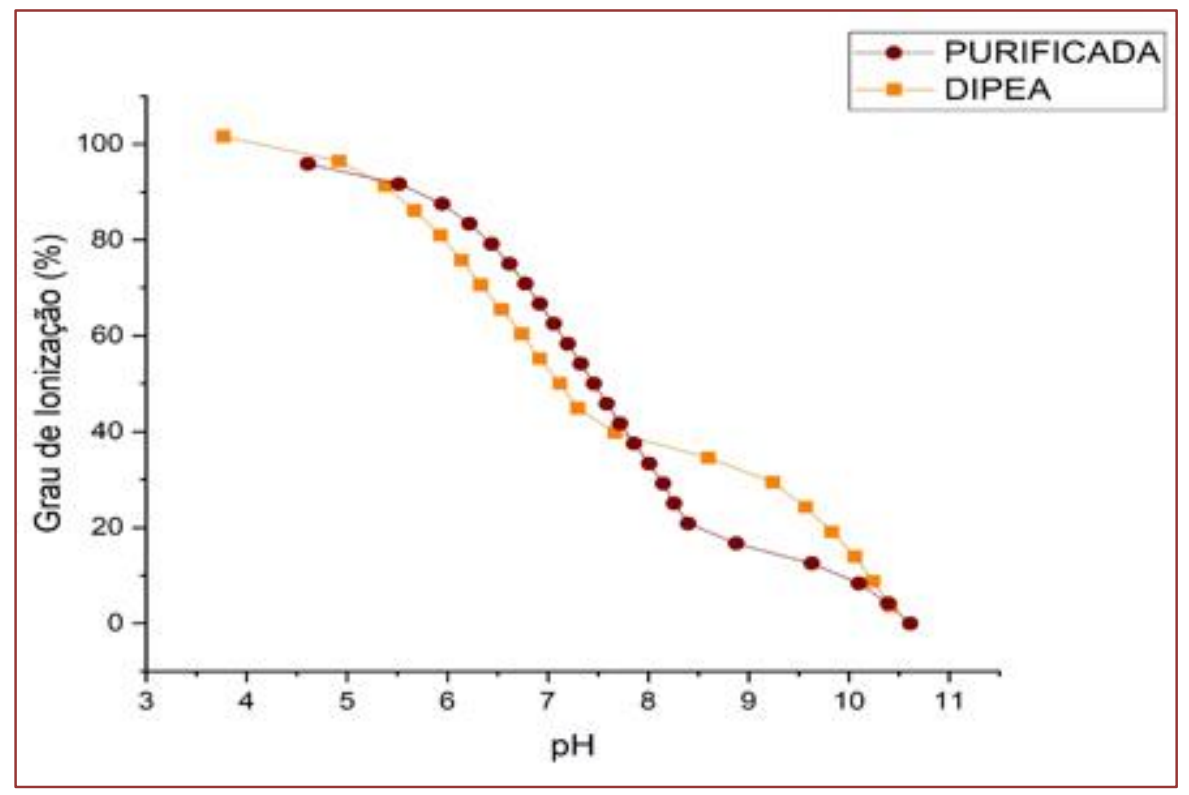


Figura 5 - Gráfico de sorção de água dos polímeros

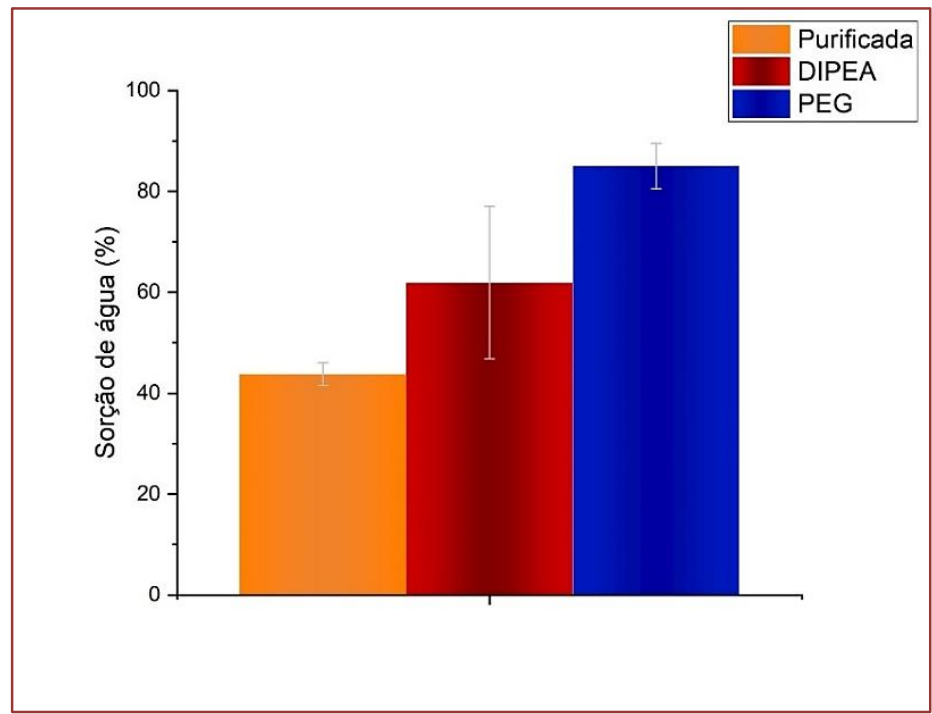

Análise estatística, realizada por meio de teste ANOVA de único fator indica um $p$-valor de 0,048, indicativo que os polímeros modificados com PEG possuíram um maior grau de sorção de água que os demais.

\subsection{CARACTERIZAÇÃO DOS POLIPLEXOS}

\subsubsection{ELETROFORESE}

O ensaio de eletroforese demostra que as nanopartículas substituídas por PEG possuem grau de interação com o siRNA reduzidos, por conta de sua maior cadeia lateral dificultar, mas impede estéricamente em algum grau a formação as nanopartículas. Isso se reflete com a liberação mais acentuada da razão N/P 2 das nanopartículas peguiladas, como pode ser observado na figura 6.

Figura 6: Eletroforese de nanopartículas de quitosana substituídas com DIPEA e peguilhadas.

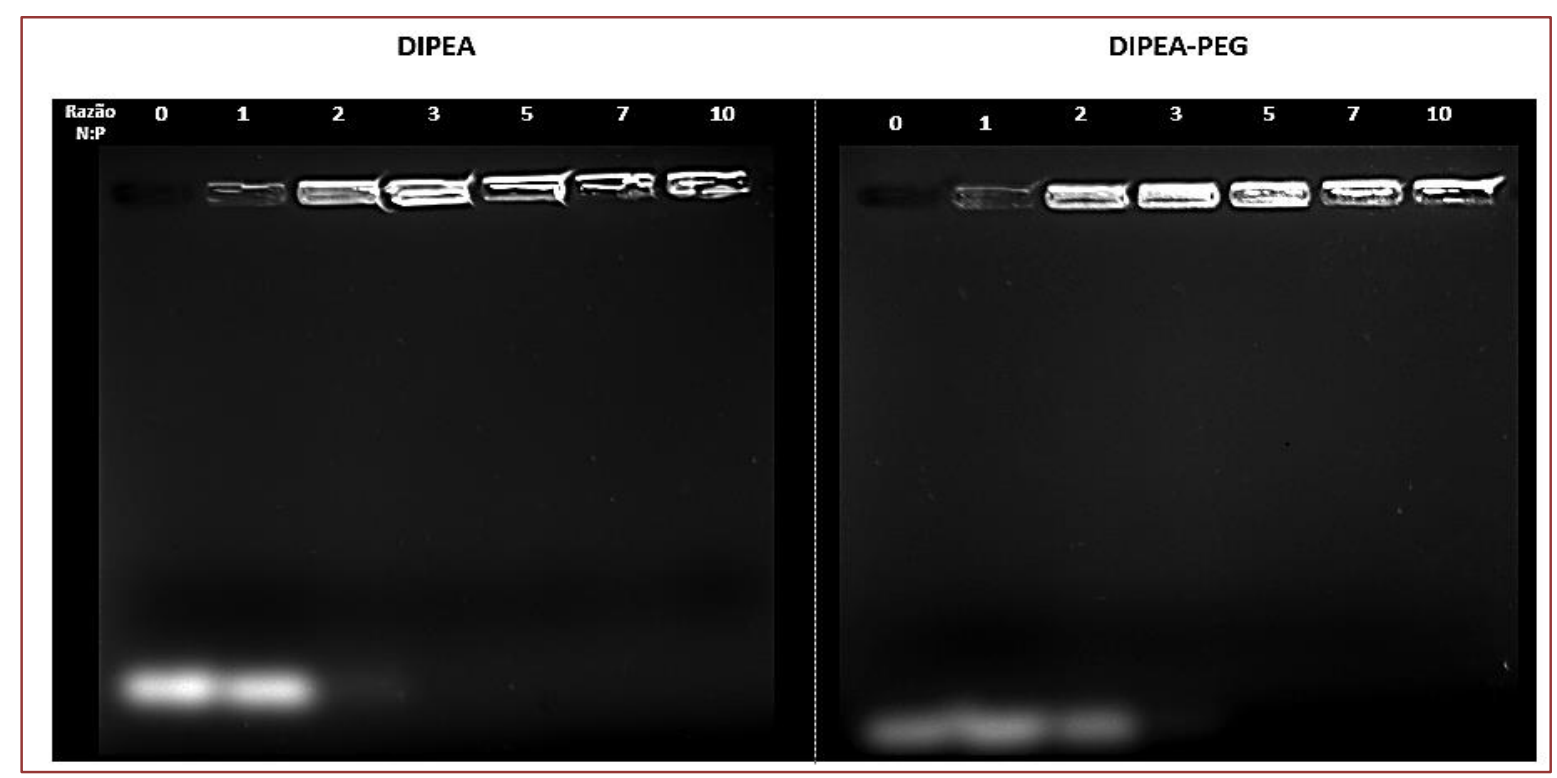




\subsection{CITOTOXIDADE}

Os polímeros e as nanopartículas devem ser as menos citotóxicas quanto o possível para minimizar o impacto da entrada destas no meio celular. A citotoxidade foi determinada pela quantidade de células viáveis após o tratamento pelos polímeros e pelas nanopartículas. Observou-se que os polímeros e as nanopartículas possuem baixíssima citotoxicidade quando comparados com as células tratadas apenas com siRNA e com tampão, respectivamente, como pode ser observado nas figuras 7 e 8.

Figura 7 - Viabilidade celular dos polímeros, em porcentagem.

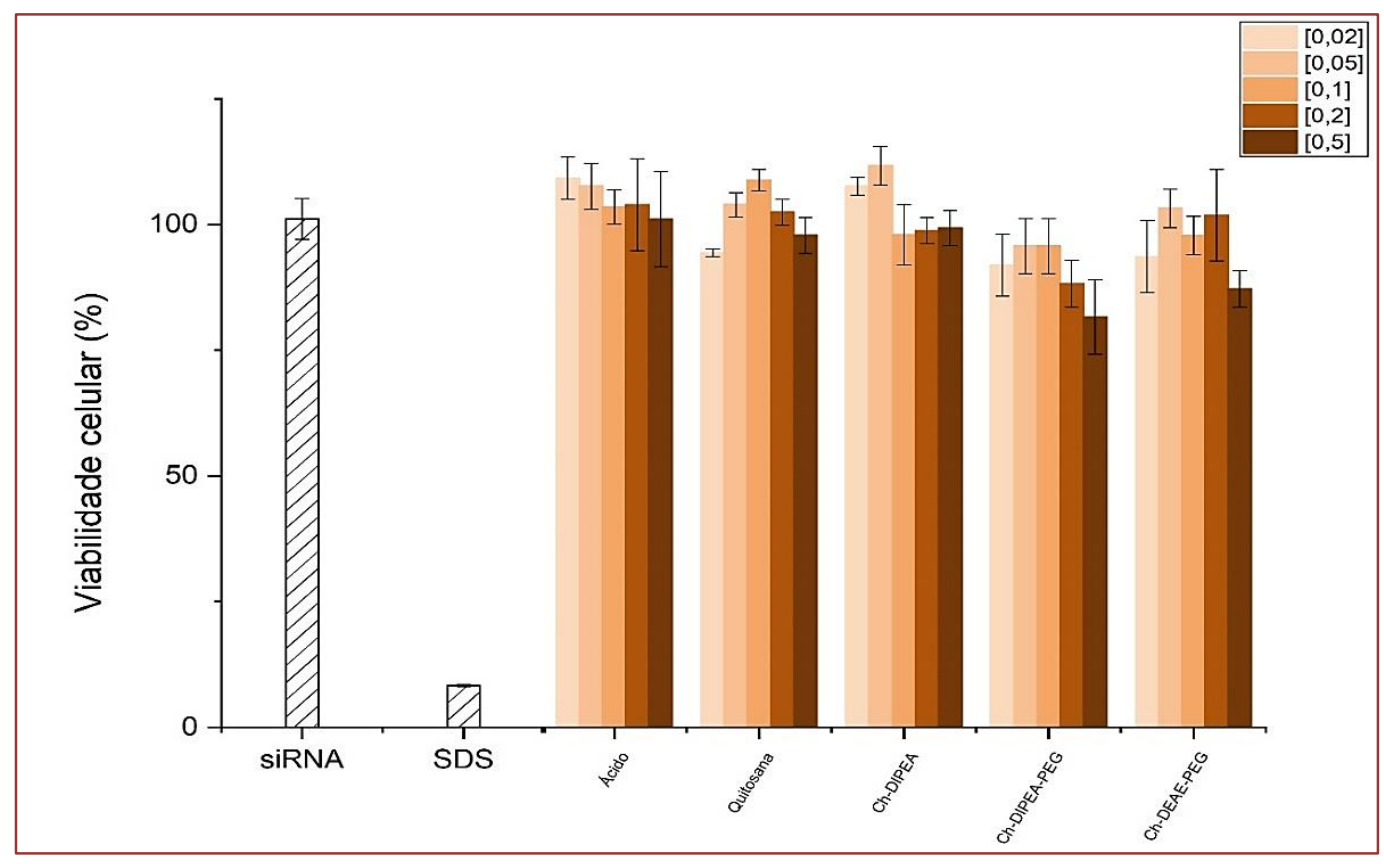

Figura 8 - Viabilidade celular das nanopartículas, em porcentagem

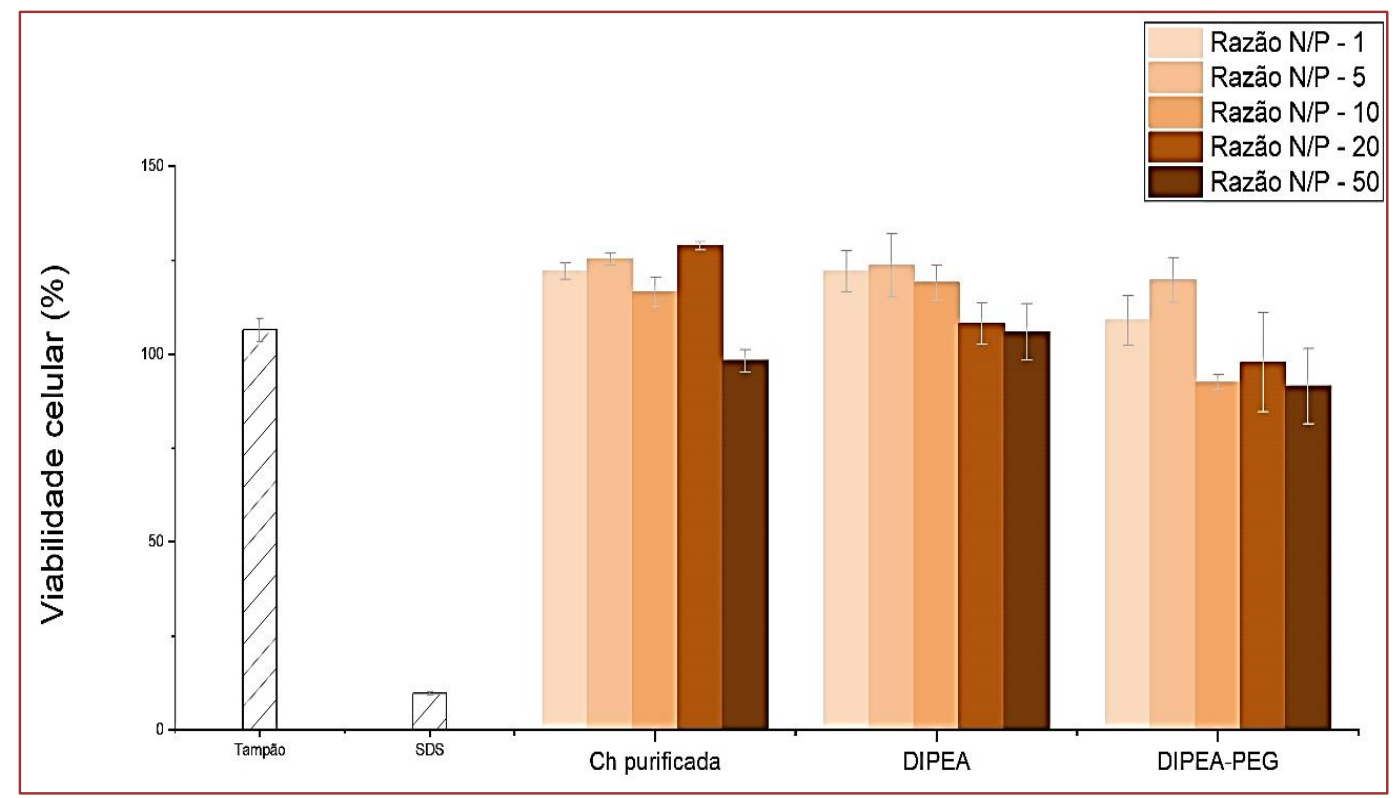




\section{CONCLUSÃO}

Construiu-se polímeros capazes de formar poliplexos de baixa citotoxidade e boa capacidade de liberação de siRNA em baixas razões de carga (N/P). As sínteses dos polímeros subsídios se mostraram de alta eficiência, tendo como média 95,5\% em todos os procedimentos de sínteses realizados.

A quitosana mostra-se, como já esperado, um polímero facilmente modificável com boa aplicabilidade como vetor não-viral para a terapia genica. Tais modificações permitem ao polímero uma maior solubilidade em meio fisiológico, bem como aumentam sua capacidade de transfecção celular, seria possível ainda por meio destas tornar os poliplexos seletivos a apenas um conjunto de células.

\section{REFERÊNCIAS}

[1]. BALLARÍN-GONZÁLEZ, Borja; HOWARD, Kenneth Alan. Polycation-based nanoparticle delivery of RNAi therapeutics: Adverse effects and solutions. Advanced Drug Delivery Reviews, v. 64, n. 15, p.1717-1729, dez. 2012.

[2]. CAO, Y. et al. Recent Advances in Chitosan-Based Carriers for Gene Delivery. Marine drugs, v. 17, n. 6,2019 .

[3]. CHANG, Kai-ling et al. Efficient Gene Transfection by Histidine-Modified Chitosan through Enhancement of Endosomal Escape. Bioconjugate Chemistry, v. 21, n. 6, p.1087-1095, 16 jun. 2010.

[4]. ELSABAHY, M.; WOOLEY, K. L. Design of polymeric nanoparticles for biomedical delivery applications. Chem Soc Rev, v. 41, p. 2545-2561, 2012.

[5]. HUANG, Min et al. Transfection efficiency of chitosan vectors: Effect of polymer molecular weight and degree of deacetylation. Journal Of Controlled Release, v. 106, n. 3, p.391-406, set. 2005.

[6]. KIM, S. H. et al. Local and systemic delivery of VEGF siRNA using polyelectrolyte complex micelles for effective treatment of cancer. Journa of Controled Release, v. 129, p. 107-116, 2008.

[7]. KÖPING-HÖGGÅRD, M et al. Improved chitosan-mediated gene delivery based on easily dissociated chitosan polyplexes of highly defined chitosan oligomers. Gene Therapy, v. 11, n. 19, p.1441-1452, 22 jul. 2004.

[8]. LAYEK, Buddhadev; SINGH, Jagdish (Org.). Caproic acid grafted chitosan cationic nanocomplexes for enhanced gene delivery: Effect of degree of substitution. International Journal of Pharmaceutics. Fargo, p. 182-191. 15 abr. 2013.

[9]. LAYEK, Buddhadev; SINGH, Jagdish (Org.). N-hexanoyl, N-octanoyl and N- decanoyl chitosans: Binding affinity, cell uptake, and transfection. Carbohydrate Polymers. Fargo, p. 403-410. 20 jun. 2012.

[10]. OLIVEIRA, F. P. P. et al. Synthesis and Evaluation of Diethylethylamine-Chitosan for Gene Delivery: Charge Density Effects on in vitro Transfection Efficiency. Nanotecnology. v. 24, p. 55-101, 2013.

[11]. SOUZA, H. F. V. de et al. Diethylaminoethyl-chitosan as an efficient carrier for siRNA delivery: Improving the condensation process and the nanoparticles properties. International journal of biological macromolecules, v. 119, p.186- 197, 2018

[12]. TIERA, Marcio J. et al. Synthesis and Characterization of Phosphorylcholine- Substituted Chitosans Soluble in Physiological pH Conditions. Biomacromolecules, v. 7, n. 11, p.3151-3156, nov. 2006.

[13]. WU, D. et al. Zinc-stabilized coloidal polyelectrolyte complexes of chitosan/hyaluronan, a tool for the inhibition of HIV-1 infection. Journal of Material Chemistry B, v. 4, p. 5455-5463, 2016. 


\title{
Capítulo 16
}

Roteiro conceitual para um instrumento de coleta de dados para avaliação de pacientes pediátricos

\author{
Deisy Mello de Pinto \\ Anali Martegani Ferreira \\ Elisiane do Nascimento Rocha \\ Darlene Rosa Tambara \\ Julia Torres Cavalheiro \\ Michele Bulhosa de Souza \\ Josefine Busanello \\ Alessandra Porto d'Avila \\ Helena Becker Issi
}

Resumo: Objetivo: elaborar, a partir da literatura, um roteiro conceitual para subsidiar a utilização de um instrumento de coleta de dados para avaliação de pacientes pediátricos. Método: Análise de conceito do modelo de Walker e Avant. Para a busca das evidências na literatura foi utilizada a modalidade narrativa, incluindo as bases LILACS, MEDLINE, PubMed, SciELO, Serviço Online e Software do Google e livros científicos impressos. Resultados: Foram conceituadas 454 variáveis (fenômenos) de enfermagem contidas no instrumento de coleta de dados, divididas em dados de identificação, anamnese e exame físico. Considerações finais: A análise do uso dos conceitos possibilitou clarificar as variáveis a serem avaliadas pelos enfermeiros na prática clínica, subsidiando a implementação das etapas do processo de enfermagem. Sugere-se a continuidade deste estudo, por meio da validação clínica e conceitual do instrumento e do roteiro, construído com foco na qualificação da assistência de enfermagem em neonatologia e pediatria.

Descritores: Enfermagem; Diagnóstico de enfermagem; Coleta de dados; Neonatologia; Pediatria; Criança. 


\section{INTRODUÇÃO}

0 cuidado à criança hospitalizada exige atenção especializada de enfermagem, devido suas especificidades e demandas de cuidados ${ }^{(1)}$. Para tanto, é necessário que a equipe de enfermagem identifique as disfunções apresentadas por esses pacientes.

A assistência sistematizada à criança hospitalizada sustenta enfermeiros para utilizar instrumentos específicos para gestão do cuidado, favorecendo o desenvolvimento do cuidado individualizado (2). Assim, o cuidado à criança deve se pautar em uma abordagem que auxilie nas dinâmicas, incluindo rotinas assistenciais, demandas e organização da família, baseado na comunicação efetiva com a equipe de enfermagem. E, apoiado em estratégias, como ambiente acolhedor, auxiliando na adaptação da criança e família à condição e demandas de cuidado durante a internação(1,2). Nesse contexto, a enfermagem deve associar condições especiais da criança e família ao seu plano assistencial, relacionadas a aspectos da infância e do convívio familiar.

Desse modo, a implementação da Sistematização da Assistência de Enfermagem (SAE) e do Processo de Enfermagem (PE) tornam-se importantes ferramentas para qualificação da atenção prestada.

A SAE é o modelo metodológico ideal para o enfermeiro aplicar seus conhecimentos técnico-científicos na prática assistencial, favorecendo o cuidado e a organização das condições necessárias para que este seja realizado(3). 0 PE é considerado a base de sustentação da SAE, sendo definido como um método para identificar problemas e demandas de cuidado, possibilitando ao enfermeiro avaliar a atenção ofertada à criança durante a prática assistencial. É constituído por fases ou etapas que envolvem a identificação de problemas de saúde, o delineamento do diagnóstico de enfermagem, a instituição de um plano de cuidados, a implementação das ações planejadas e a avaliação dessas ações ${ }^{(4,5,6)}$. Essas fases do PE estão inter relacionadas e são dependentes, sendo inseparáveis dentro do contexto do cuidado de enfermagem ${ }^{(4)}$.

A coleta de dados constitui a primeira etapa do PE, a partir da qual busca-se informações referentes ao estado de saúde da criança, da família e da comunidade, e tem como propósito identificar as necessidades de cuidado e as reações humanas. Quanto mais consistentes e confiáveis forem esses dados, mais fácil será estabelecer o diagnóstico e as etapas subsequentes do $\mathrm{PE}^{(4)}$. Ainda, a coleta de dados é composta por duas etapas: anamnese e o exame físico. A anamnese corresponde aos dados subjetivos, ou seja, é o que a pessoa informa ou afirma; e o exame físico corresponde aos dados objetivos, os quais se referem a informações que emergem a partir da avaliação clínica realizada pelo enfermeiro(5).

Observa-se que para continuidade do cuidado de enfermagem torna-se importante o acompanhamento da criança, nas diferentes faixas etárias, por meio de instrumento de coleta de dados de enfermagem, com definições conceituais claras e objetivas, que possibilite que os enfermeiros identifiquem as características apresentadas pela criança. E, apontem para identificação de possíveis riscos relacionados a condições de saúde clínicas específicas, e também contribuam para avaliação ampla sobre seu desenvolvimento.

Avaliar clinicamente a criança doente, em ambiente hospitalar, impõe aos enfermeiros um olhar clinicamente apurado e cuidadoso que permita a identificação acurada de características definidoras (sinais e sintomas) que permitam a identificação de alterações, possíveis disfunções, diagnósticos de enfermagem (Nanda, ano, Hokenberry, ano). Exige também análise de aspectos relacionados ao seu desenvolvimento infantil, sinais considerados típicos e atípicos. Tendo como referência os marcos do desenvolvimento típico refletidos na Caderneta de Saúde da Criança (Ministério da Saúde), considerando as condições de saúde de cada criança e suas demandas de cuidado. Para tanto, é fundamental a clareza conceitual das variáveis que compõem os instrumentos, de forma contribuir com uma avaliação acurada.

É importante ressaltar que a eficácia do PE depende de uma avaliação clínica rigorosa e bem estabelecida pelo enfermeiro. Dessa forma, incorporar o PE é uma forma de qualificar a assistência de enfermagem, promovendo um cuidar de enfermagem humanizado, contínuo e com qualidade para a criança e sua família. Assim, a motivação para este estudo emergiu a partir da atuação de vivências em unidade pediátrica, de uma das pesquisadoras enquanto enfermeira residente na área de Urgência e Emergência, no cenário de prática de uma unidade pediátrica, nas quais observam-se desafios enfrentados pelos enfermeiros para implementação do cuidado de forma sistematizada, especialmente o desenvolvimento de todas as etapas do PE, conforme previsto pela Resolução № 358/2009, do Conselho Federal de Enfermagem( ${ }^{(6)}$.

Outro aspecto importante refere-se à área pediátrica ter disponível um instrumento de coleta de dados para pacientes neonatos e pediátricos, o qual não está implementado na prática clínica. Todavia, ao buscar 
sua implementação deparou-se com desafios relacionados à compreensão semântica dos termos e conceitos diagnósticos de enfermagem.

Nessa perspectiva, a construção de um roteiro para subsidiar a compreensão conceitual de variáveis constantes em um instrumento de coleta de dados apoiado em linguagem padronizada, permitiu identificar o significado dos conceitos que subsidiam a denominação de variáveis que compõem o instrumento, com possibilidades de generalização/aplicabilidade pelo enfermeiro na prática clínica em outros contextos pediátricos, pois refletem demandas de cuidado às crianças hospitalizadas. Dessa forma, contribuindo para estabelecimento da implementação da primeira etapa do PE; e para registros e documentação em prontuário no que refere-se ao cuidado ofertado à criança e à família.

Nesse sentido, esse trabalho teve como objetivo elaborar, a partir da literatura, um roteiro conceitual para subsidiar a utilização de um instrumento de coleta de dados para avaliação de pacientes pediátricos.

\section{MÉTODO}

\subsection{TIPO DE ESTUDO}

0 presente estudo foi desenvolvido a partir de uma análise de conceito baseada no modelo de Walker e Avant(8).

\subsection{ANÁLISE DE CONCEITO}

A análise de conceito engloba revisão da literatura e a construção do conhecimento sobre uma determinada temática em estudo. 0 modelo de Walker e Avant ${ }^{(8)}$ tem referência direta com a enfermagem e, mais especificamente, com os sistemas de classificação da linguagem da enfermagem. A análise de conceito pode ser utilizada quando os conceitos identificados exigirem esclarecimento ou maior desenvolvimento seja para a pesquisa, teoria ou prática ${ }^{(9)}$.

Nesse estudo a análise de conceito foi realizada para subsidiar busca de evidências na literatura sobre possíveis usos dos conceitos dos fenômenos de enfermagem constantes em um instrumento de coleta de dados para neonatos e crianças hospitalizadas. Para auxiliar sua execução foi realizada uma pesquisa bibliográfica por meio da revisão narrativa de literatura(10).

0 modelo de análise de conceito de Walker e Avant ${ }^{(8)}$ apresenta oito etapas, as quais são 1) Seleção dos conceitos; 2) Determinar os objetivos da análise; 3) Identificar os possíveis usos do conceito; 4) Determinar os atributos críticos ou essenciais; 5) Apresentação dos resultados; 6) Identificar casos limítrofes, relacionados, contrários, inventados e ilegítimos; 7) Identificar antecedentes e consequências; 8) Definir as referências empíricas.

As etapas 1, 2 e 3 foram descritas juntamente com as fases 1 e 2 da revisão narrativa de literatura, pois se equivalem e ocorrem concomitantemente.

A etapa 4 - Determinação dos atributos críticos ou essenciais - para identificação dos conceitos dos fenômenos de enfermagem, foi realizada mediante leitura profunda e detalhada dos estudos selecionados. Para a identificação dos conceitos, descritos na literatura, foram elaboradas as seguintes questões: Como esse conceito é definido na literatura?

As etapas 5, 6, 7 e 8 não foram realizadas, pois não foram necessárias para atingir o objetivo do estudo.

\subsection{REVISÃO NARRATIVA DA LITERATURA}

De acordo com a terceira etapa do modelo de Walker e Avant(8), a revisão da literatura deve ser ampla e abrangente. Algumas etapas do modelo de análise de conceito são equivalentes e ocorrem paralelas ou anterior às fases da revisão integrativa, especialmente as etapas seleção do conceito, determinação dos objetivos e identificação dos possíveis usos dos conceitos, sendo assim a descrição dessas três etapas da análise de conceito foi realizada concomitante às fases da revisão narrativa.

1) Identificação da questão de pesquisa/seleção do conceito/determinação dos objetivos da análise: identificaram-se os conceitos que nomeiam os fenômenos de enfermagem descritos no instrumento e sua descrição na literatura, visando dar clareza e definição conceitual. Assim, elaborou-se a seguinte questão norteadora: Quais são as definições conceituais para as variáveis incluídas no instrumento em estudo? 
2) Busca na literatura/identificação dos possíveis usos dos conceitos: a revisão narrativa permitiu a identificação dos conceitos que nomeiam fenômenos de enfermagem, por meio da utilização de documentos científicos, tais como textos, capítulos de livros e teses, artigos de revista impressas e/ou eletrônicas da área em estudo, para interpretação, análise crítica do estudo, bem como para descrever e discutir o desenvolvimento do tema em estudo, sob ponto de vista teórico ou contextual( ${ }^{(9)}$. Essa categoria tem papel fundamental para a educação continuada e educação permanente, pois permite aquisição de conhecimentos, embora não permita sua reprodução de dados quantitativos para questões específicas.

Foram utilizados descritores em ciências da saúde (DECS) e palavras-chave. Os DECS foram Enfermagem, Diagnóstico de enfermagem, Coleta de dados, Neonatologia, Pediatria e Criança; e palavras-chave que referem-se a especificidade de cada variável que compõem as partes do instrumento (anamnese e exame físico). A pesquisa bibliográfica foi realizada via eletrônica e manual. Para contemplar as definições dos usos dos conceitos das variáveis em estudo, a pesquisa bibliográfica foi composta por 68 bibliografias disponíveis online e impressas. Na base de dados LILACS foram utilizados 16 artigos, na PubMed 02 artigos, na SciELO 09 artigos; na busca livre nos Serviços Online e Software do Google foram utilizados 18 estudos; e 23 livros científicos impressos da área em estudo(10). Foram incluídas as referências que abordaram conceitos dos fenômenos (variáveis) em estudo.

Este material foi submetido a atualização, pelas autoras, em sua etapa revisão de literatura, em setembro de 2021.

3) Avaliação dos dados: para avaliação dos estudos foi realizada leitura inicial do título e do resumo; e ao evidenciar a possibilidade de identificação dos conceitos que nomeiam fenômenos de enfermagem, realizou-se uma segunda e terceira leituras dos materiais para confirmar se refletiam o uso dos conceitos em estudo.

4) Análise dos dados: baseou-se na análise crítica das evidências conceituais descritas na literatura científica, que refletiam os conceitos que nomeiam os fenômenos em estudo, conforme Walker e Avant( ${ }^{(8)}$.

\subsection{ESTRUTURAÇÃO DO INSTRUMENTO DE COLETA DE DADOS}

0 instrumento de coleta de dados para avaliação clínica foi construído previamente para coleta de dados de pacientes hospitalizados neonatos e pediátricos, por meio de um projeto de extensão. Este não foi submetido à validação clínica, pois as enfermeiras da área apontaram a necessidade de esclarecer suas variáveis. Assim, este estudo buscou esclarecer os possíveis usos dos conceitos (fenômenos de enfermagem) para avaliação de crianças em neonatologia e pediatria.

Este instrumento apresentava-se dividido em três partes, dados de identificação, anamnese e exame físico, seguindo modelo validado em estudo conduzido por Ferreira(12) na mesma instituição. Têm como foco a avaliação clínica, identificação dos problemas de saúde, processos vitais reais ou potenciais (diagnósticos de enfermagem)(12).

Considerando sua importância para avaliação clínica por enfermeiros, este estudo buscou a construção de um roteiro para clarificar os possíveis usos dos conceitos que compõem esse instrumento de coleta de dados.

\subsection{ASPECTOS ÉTICOS}

Este projeto de extensão foi registrado no sistema de registros de projetos da Universidade Federal do Pampa (UNIPAMPA) sob no-10.268.16. Esteve alinhado a um projeto de pesquisa denominado Construção e validação de um instrumento de coleta de dados para avaliação clínica de pacientes hospitalizados (Ferreira, 2015), aprovado no CEP sob parecer no 103.199. E, também vinculado ao Programa Educação pelo Trabalho da Universidade Federal do Pampa (UNIPAMPA).

O instrumento de coleta de dados em estudo foi organizado por uma estudante bolsista, uma enfermeira preceptora na unidade de terapia intensiva neonatal, e uma docente, tutora do Programa PET Saúde Redes de Atenção - SOS Urgência e Emergência da Universidade Federal do Pampa (UNIPAMPA), no período de 2013 a 2014. A construção conceitual do roteiro foi organizada durante o desenvolvimento do trabalho de conclusão de residência de uma enfermeira residente do Programa de Residência Multiprofissional da UNIPAMPA - Urgência e Emergência. A enfermeira residente desenvolvia atividades também nas áreas de 
intensivismo neonatal e pediátrico. Desse modo, suas vivências acadêmica e assistencial possibilitaram análise a partir da literatura para construção conceitual das variáveis que constituíram o instrumento de coleta de dados para subsidiar o cuidado a crianças hospitalizadas em uma instituição hospitalar da fronteira oeste do RS. Instituição esta coparticipante neste projeto.

Os dados conceituais utilizados foram referenciados de forma a proteger os direitos autorais, conforme a lei N.ㅇ 9.610/1998.

\section{RESULTADOS E DISCUSSÃO}

0 roteiro construído ${ }^{(10)}$ segue a organização do instrumento ao qual buscou definir o uso dos conceitos de enfermagem. Desse modo, apresenta-se a discussão dos itens do roteiro dividido em dados de identificação, anamnese e exame físico.

Foram conceituadas 15 variáveis referentes aos dados de identificação da mãe e do neonato ou criança; 20 variáveis da anamnese, dessas, 06 referem-se à história de saúde da mãe e 14 variáveis relacionadas aos dados específicos do neonato ou criança; e após retiradas as variáveis repetidas foram conceituadas o total de 419 variáveis referentes ao exame físico, incluindo nove domínios (D), classes, perguntas que direcionam para evidências diagnósticas, diagnósticos de enfermagem (DE), características definidoras (CD) e fatores relacionados (FR).

Em relação às variáveis, referentes aos dados de identificação da mãe, o instrumento apresenta a variável procedência, que se refere à proveniência ou origem ${ }^{(13)}$. Estudos apontam para importância de, além dessa variável, incluir-se a variável naturalidade, como pode ser observado em outros instrumentos de coleta de $\operatorname{dados}^{(14,15,16,11)}$, uma vez que o entendimento do enfermeiro pode estar relacionado com o local de onde a mãe estava anteriormente à unidade pediátrica ou local de nascimento.

As variáveis referentes ao histórico da mãe são fundamentais a serem avaliadas, pois apontam diretamente para as condições de saúde da criança (realização do pré-natal, quantidade de consultas do pré-natal). Essas visam identificar e implementar ações para minimizar possíveis problemas de saúde que podem trazer prejuízos à saúde da mãe ou do neonato e criança, bem como garantir a qualidade dos cuidados pré-natais ofertados à família(17).

Dentre os dados de anamnese do neonato e criança, estudo aponta para importância de avaliar também variáveis sobre o histórico pregresso, como histórico de doenças crônicas, cirurgias e hospitalizações(18). Assim, sugere-se a inclusão dessas variáveis em estudo para validação do instrumento e desse roteiro.

A variável Idade gestacional foi conceituada considerando-se que o período de RN a termo é de 37 semanas completas até menos de 42 semanas completas(19). Essa classificação também é utilizada na instituição coparticipante deste estudo. Todavia, o Colégio Americano de Obstetras e Ginecologistas (ACOG), em 2013 redefiniu o início da gestação a termo, sendo o período que vai de 39 semanas a 40 semanas e 6 dias, baseados em pesquisas que apontaram a incidência recorrente de problemas específicos em grupos de neonatos com idade gestacional inferior a 39 semanas. Entre 37 e 39 semanas (20), o bebê atravessa uma fase crítica de desenvolvimento do cérebro, dos pulmões e do fígado, alerta o Instituto Nacional (norte-americano) de Saúde da Criança e Desenvolvimento Humano (NICHD)(19). Foi mantido o conceito utilizado na unidade hospitalar da qual a enfermeira residente realiza prática (instituição coparticipante), pois o conceito atual ainda não estava em consenso nessa unidade.

A coleta de dados, referente ao exame físico, está organizada conforme a Taxonomia II NANDA-I(12), incluindo domínios, classes e DE. No roteiro em estudo, identificou-se conceitos de variáveis do exame físico, contemplando os domínios D1-Promoção da saúde, D2-Nutrição, D3-Eliminação e troca e D4Atividade e repouso.

No domínio D1-Promoção da saúde foram conceituadas 15 variáveis, as quais se referem aos DE, FR e CD. Esse domínio refere-se à motivação e desejo da pessoa, família ou comunidade de aumentar o bem-estar e o potencial de saúde da criança(12). Esse conceito sustenta-se no objetivo principal abordado pela Política Nacional de Atenção Integral à Saúde da Criança, na qual declara que a promoção e a proteção da saúde da criança deve ser priorizada mediante atenção e cuidados integrados e integrais, principalmente na população pediátrica até 09 anos de idade(21). Refletindo esse objetivo, observa-se a presença do DE Proteção Ineficaz, o qual pode ser relacionado à presença de determinantes das situações que demandam atenção à saúde, tais como distúrbios imunológicos, perfis sanguíneos anormais e terapia com medicamentos apontados no instrumento e conceituados neste roteiro ${ }^{(10)}$. 
No D2- domínio Nutrição foram conceituadas 89 variáveis. Esse domínio aponta, na avaliação de neonatos e crianças, necessidade e condições de ingestão e uso de nutrientes para manter e reparar tecidos e produzir energia ${ }^{(2,12)}$. Desse modo, a partir da confirmação do uso dos conceitos dessas variáveis, os DE presentes nesse domínio (Padrão ineficaz de alimentação do lactente, Risco de glicemia instável, Icterícia neonatal, Risco de desequilíbrio eletrolítico, Volume de líquido deficiente, Volume de líquidos excessivos) são fundamentais para avaliação sobre as condições e exigências nutricionais para o crescimento e desenvolvimento da criança ou neonato ${ }^{(2,22,23)}$.

No domínio D3- Eliminação e troca foram identificados o uso dos conceitos para os DE Eliminação urinária prejudicada, Constipação, Diarreia, Troca de gases prejudicada, os quais refletem demandas de cuidados relacionados à função urinária e gastrointestinal(24,22,23,25,26,27).

Na literatura, estudos apontam para a ausência de divergência desses conceitos ${ }^{(1,30)}$. Todavia, identificouse no uso específico dos conceitos das variáveis das perguntas que direcionam para evidências diagnósticas, equívoco relacionado ao local de descrição destas. Assim, ao refinar esses conceitos confirma-se que as variáveis ileostomia e colostomia, devem ser alocadas para função gastrintestinal. Sugere-se ser acrescentado na função urinária, a variável cistostomia (inserção de cateter diretamente na bexiga através de punção ou incisão suprapúbica, para desviar o fluxo da urina da uretra temporariamente, quando a via uretral é invulnerável, por ocorrência de lesões, estenoses ou procedimentos cirúrgicos) ${ }^{0}$.

No Domínio D4- Atividade e repouso realizou-se a identificação do uso dos conceitos dos DEs Débito cardíaco diminuído, Padrão respiratório ineficaz, Perfusão Tissular periférica ineficaz, Resposta disfuncional ao desmame ventilatório, Ventilação espontânea prejudicada, e suas CDs, FRs(10), bem como das questões que direcionam para evidências diagnósticas. Esses DEs foram identificados em outros estudos realizados em pediatria $(21,22,24,25)$. Esse domínio aponta variáveis para avaliação específica das respostas cardiovasculares e pulmonares para neonatos e crianças, as quais refletem demandas de cuidados de enfermagem específicas. Dentre as variáveis conceituadas observou-se a necessidade de explorar os modos ventilatórios abordados, em função das dificuldades enfrentadas pelos enfermeiros durante a avaliação clínica. Assim, clarificar o uso dos conceitos relacionados a modalidades de ventilação mecânica apontam para importância de reorganizar as variáveis relacionadas ao modo ventilatório e associá-las às suas especificidades (pressão e volume). Para as demais variáveis identificou-se o uso dos conceitos descritos na literatura científica, estando em consenso(21,24,1).

Analisando o uso dos conceitos da totalidade de domínios da classificação da II NANDA-I(10), e os constantes no instrumento no qual se baseou este estudo, percebe-se a importância da inclusão do D-13 Crescimento e desenvolvimento (aumentos adequados à idade nas dimensões físicas, amadurecimento de sistemas e órgãos e/ou progresso ao longo dos marcos do desenvolvimento), onde se incluem dois DE (Risco de crescimento desproporcional e Risco de desenvolvimento atrasado). Observa-se sua potencialidade para avaliação de demandas de saúde, uma vez que refere-se a alterações específicas nas faixas etárias, dentre as quais se destaca a avaliação do neonato e da criança.

Ainda, nas questões relativas ao gerenciamento do cuidado de enfermagem à criança, faz-se mister considerar singularidades próprias da infância que exigem um olhar ampliado incluindo avaliação das condições clínicas, maior sensibilidade e organização do profissional enfermeiro. Cabe, igualmente, considerar o processo de crescimento e desenvolvimento, as especificidades anatomofisiológicas do organismo infantil, o desenvolvimento cognitivo de cada faixa etária, além do processo de comunicação com a criança, a família e as equipes envolvidas ${ }^{(29)}$,

\section{CONSIDERAÇÕES FINAIS}

Este estudo permitiu analisar o uso dos conceitos que nomeiam os fenômenos (variáveis) de enfermagem a partir da construção de um roteiro. Nos dados de identificação foram conceituadas 15 variáveis, na anamnese 20 variáveis e referentes ao exame físico o total de 419 variáveis.

A análise do uso dos conceitos possibilitou identificar as variáveis a serem avaliadas pelos enfermeiros na prática clínica, subsidiando a implementação das etapas do PE, mostrando-se primordial para a valorização do trabalho do enfermeiro e qualidade do cuidado a ser implementado.

A construção desse roteiro permitiu subsidiar e instrumentalizar os enfermeiros e estudantes de enfermagem que atuam no cuidado a neonatos e crianças à realização da primeira etapa do PE. Possibilitou a compreensão do uso dos conceitos científicos utilizados para descrever os fenômenos de 
enfermagem, promovendo a comunicação por meio de uma linguagem de enfermagem, e ao mesmo tempo, integrando o conhecimento científico teórico e prático da profissão.

Observa-se como limitação para a realização desse estudo, a dificuldade para identificar o uso dos conceitos na literatura, visto que há vários estudos referentes a instrumentos para avaliação clínica, mas poucos que contemplem os conceitos das variáveis (fenômenos). Sugere-se que a continuidade deste estudo possa ser realizada, por meio da validação clínica e conceitual do instrumento em estudo e do roteiro construído com foco na qualificação da assistência de enfermagem em neonatologia e pediatria na instituição coparticipante e para profissionais que atuam na área da infância.

\section{REFERÊNCIAS}

[1]. Hockenberry MJ, Wilson D, editores. Wong, fundamentos de Enfermagem Pediátrica. 9 ed. Rio de Janeiro: Elsevier, 2014.

[2]. Oliveira, C S B, Silva, M. Representações sociais de enfermeiros que cuidam de crianças sobre a sistematização da assistência de enfermagem. Revista Gaúcha de Enfermagem [online]. 2017, v. 38, n. 3 [Acessado 22 Setembro 2021] , e66840. Disponível em: <https://doi.org/10.1590/1983-1447.2017.03.66840>. Epub 12 Abr 2018. ISSN 1983-1447. https://doi.org/10.1590/1983-1447.2017.03.66840.

[3]. Garcia TR, Nóbrega MML. Sistematização da assistência de enfermagem: reflexões sobre o processo. In: Anais do 52o Congresso Brasileiro de Enfermagem; 2000 Out 21-26; Recife, Brasil. Associação Brasileira de Enfermagem; 2000.

[4]. Alfaro-Lefevre R. Aplicação do processo de enfermagem: uma ferramenta para o pensamento crítico. 7.ed. Porto Alegre: ArtMed, 2010.

[5]. Tannure MC, Pinheiro AM. SAE: Sistematização da Assistência de Enfermagem:Guia prático. 2.ed. Rio de janeiro: Guanabara Koogan, 2011.

[6]. Conselho Federal de Enfermagem (COFEn). Resolução 358/2009 do Conselho do Federal de Enfermagem, 2009.Dispõe sobre a Sistematização da Assistência de Enfermagem e a implementação do Processo de Enfermagem em ambientes, públicos ou privados, em que ocorre o cuidado profissional de enfermagem, e dá outras providências, 2009.

[7]. Walker LO, Avant KC. Strategies for theory construction in nursing. 4th ed. Pearson Prentice Hall; Upper Saddle River, NJ: 2005.

[8]. McewenM, Wills EM. Bases teóricas da enfermagem. 2ª̣ed. Porto Alegre: Artmed, 2009.

[9]. Rother ET. Revisão Sistemática x Revisão Narrativa (editorial). Acta Paul Enferm 2007; 20 (2):vi.

[10]. PINTO, Deisy Mello de Pinto. Construção de um roteiro para um instrumento de coleta de dados para avaliação clínica de pacientes pediátricos hospitalizados. 73p. Monografia (Especialização - Residência Integrada em Multiprofissional em Urgência e Emergência) - Universidade Federal do Pampa, Campus Uruguaiana, Uruguaiana, 2018. acesso: http://dspace.unipampa.edu.br:8080/jspui/handle/riu/4948

[11]. Ferreira AM. Construção e validação de um instrumento de coleta de dados para avaliação clínica de pacientes em terapia intensiva. São Paulo, 2015. Tese (Doutorado) - Universidade Federal de São Paulo. Escola Paulista de Enfermagem. Programa de Pós-Graduação em Enfermagem.

[12]. Diagnósticos de Enfermagem da NANDA: definições e classificação 2018-2020/ NANDA International; tradução Regina Machado Garcez. - Porto Alegre: Artmed, 2018.

[13]. Ferreira, ABH. Mini Aurélio: o dicionário da língua portuguesa. 8 ed. Curitiba: Positivo, 2010.

[14]. Lima NDC, Silva VM, Beltrão BA. Construção e validação de conteúdo de instrumento de coleta de dados em unidade neonatal. Rev. Rene. Fortaleza, v. 10, n. 3, p. 97-106, jul./set.2009.

[15]. Barros, ALBLB. Anamnese e exame físico: avaliação diagnóstica de enfermagem no adulto. 3 ed. Porto Alegre: Artmed; 2016.

[16]. Neto JMR, Fontes WD, Nóbrega MML. Instrumento de coleta de dados de enfermagem em Unidade de Terapia Intensiva Geral. RevBrasEnferm, Brasília 2013 jul-ago; 66(4): 535-42

[17]. Brasil. Ministério da Saúde. Secretaria de Atenção à Saúde. Departamento de Atenção Básica. Atenção ao prénatal de baixo risco. 1. ed. rev. - Brasília: Editora do Ministério da Saúde, 2013.

[18]. Marques, DKA. Construção e validação de um instrumento para implementação do processo de enfermagem em escolares hospitalizados. João Pessoa. 2015 Tese (Doutorado) UFPB/CCS 
[19]. Rodrigues YT, Rodrigues PPB. Semiologia pediátrica. 3.ed. Rio de Janeiro: Guanabara Koogan, 2009.

[20]. Conselho Federal de Medicina(CFM). Define critérios para realização de parto cesariano. Disponível em: < https://portal.cfm.org.br/noticias/em-resolucao-cfm-define-a-idade-gestacional-para-realizacao-de-cesarianaseletivas>. Acesso em: set 2021

[21]. Brasil. PORTARIA № 1.130, DE 5 DE AGOSTO DE 2015. Institui a Política Nacional de Atenção Integral à Saúde da Criança (PNAISC) no âmbito do Sistema Único de Saúde (SUS). Disponível em: <http://www.brasilsus.com.br/images/portarias/agosto2015/dia06/portaria1130.pdf>. Acesso em: set 2021

[22]. Oliveira ALG. Manual de orientação sobre diagnósticos e intervenções de enfermagem para a clientela pediátrica. / André Luiz Gomes de Oliveira. - Niterói: [s.n.], 2015.

[23]. Silva VG, Pereira JM, Figueiredo LS, Guimarães TC, Cavalcanti AC. Diagnósticos de Enfermagem em crianças com cardiopatias congênitas: mapeamento cruzado. Acta Paul Enferm. 2015; 28(6):524-30.

[24]. Miranda FR, Lourenço Junior L, Miotto Junior A, Napoleão AA. Características definidoras do diagnóstico de enfermagem eliminação urinária prejudicada em lactentes: revisão integrativa. REME rev. min. Enferm. 2013; 17(3): 720-725.

[25]. Santiago JMV. Diagnósticos de enfermagem respiratórios em crianças com cardiopatias congênitas em evolução pós operatória. Ceará, 2013. Dissertação (Mestrado) - Universidade do Ceará.

[26]. Andrade LZC, Silva VMM, Lopes VO, Chaves DBR, Távora RCO. Desobstrução ineficaz de vias aéreas: prevalência e espectro de seus indicadores clínicos. Acta Paul Enferm. 2014; 27(4):319-25.

[27]. Pascoal LM, Lopes MVO, Chaves DBR, Beltrão BA, Silva VM. Troca de gases prejudicada: acurácia das características definidoras em crianças com infecção respiratória aguda. Rev. Latino-Am. Enfermagem maio-jun. 2015;23(3):491-9.

[28]. Brunner e Suddarth. Manual de Enfermagem Médico-Cirúrgica. 14a edição. Rio de Janeiro: Guanabara Koogan, 2020.

Silva TP, Silva MM, Valadares GV, Silva IR, Leite JL. Nursing care management for children hospitalized with chronic conditions. Rev Bras Enferm. 2015;68(4):641- 8. doi: http://dx.doi.org/10.1590/0034-7167.2015680410i. 


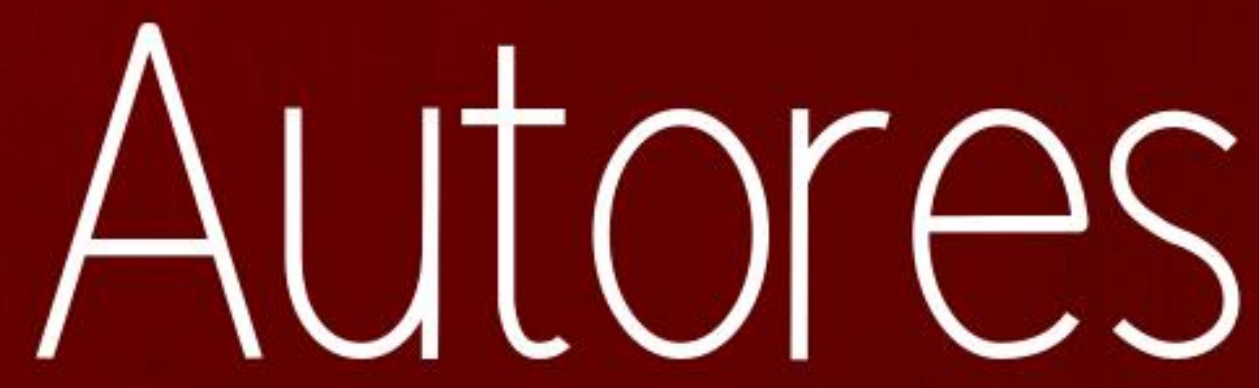




\section{GLEICA SOYAN BARBOSA ALVES (ORGANIZADORA)}

Farmacêutica (UFAM - 2013), mestre em Saúde, Sociedade e Endemias na Amazônia (UFAM - 2016) professora assistente da Universidade Federal do Amazonas (UFAM) e Coordenadora do Curso de Engenharia Sanitária do Instituto de Ciências Exatas e Tecnologia (ICET). Tem experiência na área de Microbiologia, Epidemiologia, Biologia Molecular e Controle de Qualidade de Alimentos e Medicamentos.

\section{ELIENE DE OLIVEIRA (ORGANIZADORA)}

Graduada em Odontologia pela Universidade Estadual de Montes Claros - Unimontes (2017) e em Enfermagem pelas Faculdades Unidas do Norte de Minas - FUNORTE (2011). Especialista em Saúde da Família. Especialista em Educação a Distância. Servidora pública efetiva no cargo de Odontológo na Prefeitura Municipal de Montes Claros/MG. Docente na Escola Técnica de Saúde do Centro de Educação Profissional e Tecnológica da Unimontes. Professora supervisora do Estágio em Saúde da Família do curso de Odontologia da FUNORTE. Possui experiência em Saúde Coletiva/Saúde da Família.

\section{ALCIR JOSÉ DE OLIVEIRA JÚNIOR}

Graduado na Faculdade de Odontologia de Ribeirão Preto - USP (2017). Especialista em Gestão Pública em Saúde na Universidade Estadual de Campinas - UNICAMP (2019) e Política, Planejamento, Gestão e Avaliação em Saúde Bucal na Universidade Federal de Pernambuco - UFPE (2019). Mestre em Gestão e Saúde Coletiva na Faculdade de Odontologia de Piracicaba - UNICAMP (2020). Atualmente é Doutorando em Saúde Coletiva pela Faculdade de Odontologia de Piracicaba UNICAMP.

\section{ALEXANDRE LAZZARINI MACHADO}

Enfermeiro, Faculdade Integrada de Santa Maria (FISMA). Pós Graduando em Cuidados Paliativos no adulto pela Faculdade Dom Alberto de Santa Cruz do Sul/RS Técnico em Enfermagem no Hospital de Caridade de Santa Maria/RS.

\section{ALFONSO SÁNCHEZ-AYALA}

Cirurgião-Dentista - Universidade Peruana Cayetano Heredia. Mestre em Odontologia Universidade Estadual de Ponta Grossa (UEPG). Doutor em Clínica Odontológica - Universidade Estadual de Campinas (UNICAMP). Professor Adjunto do Departamento de Odontologia Universidade Estadual de Ponta Grossa (UEPG).

\section{AMANDA SCHMITBERGER PELISSON}

Acadêmica de medicina do Centro Universitário de Belo Horizonte (UniBH), com experiência em consultas e estágios nos Centros de Saúde de Belo Horizonte e região e na Clínica Integrada de Saúdo do Unibh, onde atua como auxiliar de médicos e enfermeiros. Apresenta artigos publicados em diversas plataformas tanto nacionais quanto internacionais, capítulos de livros em forma de E-book e mostra interesse interesse em saúde coletiva e pediatria, atuando no momento como coordenadora da Liga de Pediatria do Unibh.

\section{ANA CLARA CAMARGO ROCHA}

Acadêmica de medicina do Centro Universitário de Belo Horizonte (UniBH), com experiência em consultas e estágios nos Centros de Saúde de Belo Horizonte e região, onde atua como auxiliar de médicos e enfermeiros. Apresenta interesse em área Cirúrgica e pediatria. 


\section{ANALI MARTEGANI FERREIRA}

Possui graduação em Enfermagem pela Universidade Federal do Rio Grande do Sul (2003), Residência Integrada em Saúde: ênfase Terapia Intensiva pelo Grupo Hospitalar Conceição (2006), Mestrado em Enfermagem pela Universidade Federal do Rio Grande do Sul (2009), Doutorado em Ciências pela Universidade Federal de São Paulo (2015). Atualmente é professora Adjunta do Departamento de Enfermagem Materno-Infantil da Escola de Enfermagem da Universidade Federal do Rio Grande do Sul (EE-UFRGS). Vice líder do Grupo de Estudos Cuidado à Saúde nas Etapas da Vida (CEVIDA) - EE-UFRGS.

\section{ANTONIO CARLOS PEREIRA}

Possui graduação em Odontologia pela Universidade Estadual de Campinas (1989), mestrado em Saúde Pública pela Universidade de São Paulo (1993) e doutorado em Saúde Pública pela Universidade de São Paulo (1996). Desde 2003 é professor titular da Universidade Estadual de Campinas. Realizou seu pós Doutoramento nas Universidades de Nijmegen (Holanda)- 1998 e Indiana (EUA) em 2000. Faz parte do corpo editorial de diversas revistas nacionais e internacionais, além de consultor do Ministério da Saúde e outros órgãos. Tem experiência na área de Gestão Pública em Saúde com ênfase em Odontologia, com as seguintes linhas de pesquisa: epidemiologia, gestão pública e economia da saúde. Coordenou a Pesquisa Estadual de Saúde Bucal (SB SP 2015) no Estado de SP em 2015, o Mestrado em Odontologia em Saúde Coletiva (atual MP em Gestão e Saúde Coletiva) de 2003 a 2016, além do PróSaúde e o Graduaceo na FOP UNICAMP. Publicou de 4 livros importantes na área: a) Odontologia em Saúde Coletiva:Planejando ações e Promovendo Saúde; Editora Artmed, 3a reimpressão, 2003; b) Tratado de Saúde Bucal Coletiva. Editora Napoleão, 2009, c) Gestão Pública em Saúde: Fundamentos e Práticas. Editora Livronovo, 2015 e d) Fundamentos da Gestão Pública em Saúde. ADM Gestão em Educação em Saúde (ED.), 2017.

\section{ARETUSA DE OLIVEIRA MARTINS BITENCOURT}

Enfermeira (UESC). Mestre em Enfermagem (UFBA). Especialista em Docência na Saúde (UFRGS). Especialista em Educação em Saúde (UESC). Professora Assistente do Depto. Ciências da Saúde (UESC). Coordenadora do Núcleo de Estudo, Pesquisa e Extensão em Metodologias da Enfermagem (NEPEMENF-UESC). Coordenadora do Núcleo Jovem Bom de Vida (UESC). Professora e Orientadora do Curso de Pós-Graduação em Saúde Escolar (UESC).

\section{ARTHUR GUALBERTO BACELAR DA CRUZ URPIA}

Doutor em Economia, PPGE - IE/UFRJ. Docente do Programa de Pós-Graduação em Gestão do Conhecimento, Universidade Cesumar - UNICESUMAR

\section{BRUNNA VERNA CASTRO GONDINHO}

Graduação em Odontologia pela Universidade Federal do Piauí - UFPI (2011). Especialização em Saúde Coletiva e da Família pela Faculdade de Odontologia de Piracicaba da Universidade Estadual de Campinas - FOP/UNICAMP (2013), Gestão em Saúde pela Universidade Federal de São Paulo UNIFESP (2014), Vigilância em Saúde pela Universidade Estadual do Piauí - UESPI (2014). Foi bolsista do Ministério da Saúde (MS) durante a Residência Multiprofissional em Saúde da Família e Comunidade - parceria MS/UESPI (2014 - 2016). Mestrado em Odontologia em Saúde Coletiva pela FOP/UNICAMP (2014). Doutorado em Odontologia - área saúde coletiva pela FOP/UNICAMP (2016 - 2020). Professora Efetiva da Universidade Estadual do Piauí.

\section{CAMILA GONÇALO MIALHE}

Doutora em Saúde Coletiva pela Faculdade de Ciências Médicas da UNICAMP, área de concentração: Ciências Sociais em Saúde. Professora Adjunta do Departamento de Saúde Coletiva da Faculdade de Medicina de Jundiaí (Carga Horária: 20 h/semana). Atuou junto aos graduandos do 2o ano do ensino Médico na Disciplina Atenção Primária em Saúde 1 e 2 (2012-2014); desenvolveu atividades teórico-práticas com os discentes nas Unidades Básicas e de Saúde da Família no Município de 
Jundiaí (2012-2015). Coordenou e ministrou a Disciplina Saúde e Sociedade junto aos alunos do 3o ano do ensino Médico, abordando temas sobre Medicina, Processo Saúde-Doença e Cuidado em saúde enquanto um processo social (2012-2014). Coordenou e ministrou as disciplinas: Processo Saúde/Doença e Humanidades Médicas; Políticas Públicas e Humanidades Médicas junto aos alunos do 10 ano do curso de medicina da FMJ (2015). Compôs o corpo docente da disciplina Prática e Pesquisa em Saúde da Família, aplicada aos alunos 2o ano de medicina da FMJ (2015). Ministrou as disciplinas Atenção Primária de Saúde e Saúde Ambiental; Atenção Primária de Saúde e Epidemiologia, no 20 ano de medicina, bem como atuou junto aos alunos do internato trabalhando temas teóricos de Saúde Coletiva,Epidemiologia e Práticas Integrativas e Complementares (20152016). Foi bolsista FAPESP, CAPES e do Programa de Mobilidade Estudantil UNICAMP-Santander Espanha [2009] ocasião em que desenvolveu pesquisas e atendimentos clínicos de Medicina Tradicional Chinesa na área de Atenção Primária em Saúde junto à Faculdade de Medicina da Universidade de Málaga e à Junta de Andaluzia na Unidade de Tratamento de Dor Crônica (UTD) em Dos Hermanas. Atualmente ministra as disciplinas: Políticas Públicas de Saúde (1ํano FMJ) e Atenção Primária e Educação em Saúde ( $2^{\circ}$ ano FMJ). Tem experiência na área da Saúde, com ênfase em Saúde Pública; Saúde Coletiva; Atenção Básica; Educação em Saúde;Práticas Integrativas e Complementares em Saúde. Espanha.

\section{CARINE VIANA}

Farmacêutica e bioquímica pela Universidade Federal de Santa Maria (UFSM, 1997), tem doutorado em Química pela UFSM (2010), mestrado em Ciências Farmacêuticas pela UFSM (2005), especialização em Fitoterapia (2000) e em Homeopatia pela Faculdade de Ciências da Saúde de São Paulo (2002). É professora associada na UFSM, atuando nas disciplinas de Deontologia e Legislação Farmacêutica, Assistência Farmacêutica e Clínica Farmacêutica. Orientadora do Programa de PósGraduação em Ciências Farmacêuticas, atuando em nível de mestrado e doutorado. Atua com Projeto de Extensão na Rede Pública de Saúde de Santa Maria (RS), na área de Assistência e Clínica Farmacêutica. Possui diversos artigos científicos com temas relacionados a Controle da Qualidade de Produtos Farmacêuticos e Suplementos Alimentares.

\section{CARLOS EDUARDO DE ALMEIDA}

Pós graduado em Fisioterapia Intensiva pela Faculdade de Ciências Médicas Humanitas, sócio proprietário da Empresa C.E.de Almeida Clínica de Fisioterapia.

\section{CARMEN TRIGUEROS-CERVANTES}

Profesora Titular de Universidad en el Departamento de Didáctica de la Expresión Musical, Plástica y Corporal de la Universidad de Granada.

\section{CAROLINE DIAS BRANDÃO}

Enfermeira (UESC). Especialista em Obstetrícia (UNINTER). Especialista em Saúde Pública (UNESA). Especialista em Auditoria e Sistemas de Saúde (UNESA). Especialista em Saúde Escolar (UESC). Doula. Instrutora de Yoga (Eskuela Internacional de Formación Brasil).

\section{CECILIA RODRIGUES DA SILVA NETA}

Licenciada em Letras (UNIUBE). Pós-Graduação em Docência do Ensino Superior (UNIME). PósGraduação em Saúde Escolar (UESC). Servidora Pública Municipal de Itabuna - BA.

\section{DALVANA CRISTINA DE CARVALHO ELESBÃO}

Formada em Fisioterapia na ESC (Escola Superior de Cruzeiro), em 2015 


\section{DARLENI ROSA TAMBARA}

Possui graduação em Enfermagem pela Universidade Federal do Pampa - UNIPAMPA (2010). Especialista em Saúde da Mulher pela UNIPAMPA (2014). Especialista em Gestão e Assistência em Terapia Intensiva - Faculdade FACTUM (2018). Atualmente enfermeira no Hospital Santa Casa de Uruguaiana, atuando na Unidade de Tratamento Intensivo Neonatal e Unidade Pediátrica, nas áreas assistenciais e de Responsabilidade Técnica.

\section{DEISY MELLO DE PINTO}

Possui graduação em Enfermagem pela Universidade Federal do Pampa - UNIPAMPA (2014). Especialista em Urgência e Emergência pelo Programa de Residência Integrada Multiprofissional da UNIPAMPA (2018). Atualmente enfermeira no Hospital Santa Casa de Uruguaiana, atuando na Unidade de Tratamento Intensivo Adulto. Membro do Laboratório de Estudos e Pesquisas em Cuidados Intensivos (LACIN).

\section{ELISIANE DO NASCIMENTO DA ROCHA}

Possui graduação em Enfermagem pela Universidade Federal do Pampa - UNIPAMPA (2015). Especialista em Saúde da Criança pelo Programa de Residência Multiprofissional do Hospital de Clínicas de Porto Alegre - HCPA (2017). Atualmente enfermeira no Hospital Santa Casa de Uruguaiana, atuando na Unidade de Internação Obstétrica, Unidade de Tratamento Intensivo Neonatal e Unidade Pediátrica.

\section{ELIZABETH MATILDA OLIVEIRA WILLIAMS}

Fonoaudióloga Mestre em Educação (UFAM) e Professora do Programa de Graduação do Centro Universitário Fluminense (UNIFLU)

\section{EPIFANÍA NATALIA MEDINA-ARTILES}

Profesora Titular de Escuela Universitaria en el Departamento de Enfermería desde 1995. Formación académica: Diplomada Universitaria en Enfermería por la UNED en 1989, Graduada en Enfermería por la Universidad de Las Palmas de Gran Canaria en 2015, Máster Universitario en Ciencias de la Enfermería por la Universidad de Alicante en 2007, Doctora en Enfermería por la Universidad de Alicante en 2013. Amplia experiencia docente y de gestión en la Universidad de Las Palmas. Investigación y publicaciones relacionadas con la metodología enfermera y la Innovación Educativa.

\section{FABIO BRASIL DE OLIVEIRA}

Cirurgião-Dentista - Universidade Estadual de Ponta Grossa (UEPG). Mestrando em Odontologia Universidade Estadual de Ponta Grossa (UEPG).

\section{GUSTAVO SIMÃO MORAES}

Cirurgião-Dentista - Universidade Estadual de Ponta Grossa (UEPG). Mestre e Doutorando em Odontologia - Universidade Estadual de Ponta Grossa (UEPG).

\section{ILMA ALESSANDRA LIMA CABRAL RODRIGUES}

Fonoaudióloga Especialista em Audiologia Clínica (CEFAC) e Coordenadora/Professora do Curso de Fonoaudiologia do Centro Universitário Fluminense (UNIFLU) 


\section{ISABELA DUTRA COELHO BRANDT}

Especialista em Distúrbios da Comunicação Humana (Universidade Federal de São Paulo) / Avaliação e Reabilitação do Processamento Auditivo / Fonoaudiologia Escolar. Fonoaudióloga da Prefeitura Municipal de Campos dos Goytacazes.

\section{ISABELLE FARIA SAFADI}

Acadêmica de medicina do sétimo período do Centro Universitário de Belo Horizonte. Tenho coparticipação na organização de simpósio científico, tenho experiência em consultas médicas, além da elaboração de diversos artigos científicos. Tenho interesse na área de cardiologia pediátrica. Sei me relacionar bem com os profissionais ao meu redor, me dedicando plenamente ao trabalho em equipe.

\section{JAQUELINE VILELA BULGARELI}

Possui graduação em Odontologia pela Universidade de Marília (2002), é especialista em Saúde da Família pela Faculdade de Medicina de Marília- FAMEMA. Mestre em Saúde Coletiva pela Faculdade de Odontologia de Piracicaba- FOP- UNICAMP. Doutora em Saúde Coletiva pela FOP-UNICAMP. Atuou na Coordenadoria do Programa Municipal de Saúde Bucal da Secretaria Municipal da Saúde de Marília conforme convênio estabelecido com a instituição filantrópica Associação Feminina de Marília Maternidade Gota de Leite, para o desenvolvimento da Estratégia Saúde da Família.Foi tutora do Mestrado Profissional em Odontologia em Saúde Coletiva da FOP-Unicamp. Professora do curso de Especialização em Saúde Coletiva e da Família e do curso de Especialização modalidade EAD em Gestão Pública desenvolvidos na FOP-UNICAMP. Pós doutorado na FOP-UNICAMP, bolsista CAPES do programa PNPD. Professora da área de Odontologia Preventiva e Social da FOUFUUniversidade de Uberlândia. Tem experiência na área de Odontologia, com ênfase em Odontologia, Saúde Coletiva e Gestão Pública, atuando principalmente nos seguintes temas: Saúde Bucal Coletiva, Estratégia Saúde da Família, Gestão em Odontologia Coletiva e atividades clínicas assistenciais básicas em odontologia, com ênfase em pacientes portadores de necessidades especiais.

\section{JOÃO LUIS ALMEIDA DA SILVA}

Enfermeiro (UFRGS). Mestre em Enfermagem (UFRGS). Doutor em Ciências (UNIFESP). Professor Adjunto do Dep. Ciências da Saúde (UESC). Coordenador do Laboratório de Práticas Integrativas e Complementares do Núcleo de Estudos, Pesquisa e Extensão em Metodologias na Enfermagem (LABPICS/NEPEMENF - UESC).

\section{JOSEFINA DA SILVA SANTOS}

Possui graduação em Bacharelado em Física pela Universidade do Estado do Rio de Janeiro (1998), Mestrado e Doutorado em Tecnologia Nuclear- Aplicações Nucleares peo Instituto de Pesquisas Energeticas e Nucleares (IPEN), Universidade de São Paulo. Apresenta experiência na área de radiofarmácia, atuando principalmente no desenvolvimento de novos radiofármacos para diagnóstico, e em Radioproteção, atuando em Medicina Nuclear. Atualmente é docente na Universidade Estadual de Ciências da Saúde de Alagoas.

\section{JOSEFINE BUSANELLO}

Professora Associada do Curso de Enfermagem da Universidade Federal do Pampa (UNIPAMPA). Bacharel (2006), Mestre (2010) e Doutora (2012) em Enfermagem pela Universidade Federal do Rio Grande (FURG). Líder do Laboratório de Estudos e Pesquisas em Cuidados Intensivos (LACIN), no qual desenvolve atividades de ensino, pesquisa e extensão nas áreas: Fundamentos clínicos e epidemiológicos das situações críticas de vida; Gestão e avaliação do cuidado intensivo; e Tecnologias inovadoras para o cuidado intensivo. Coordenadora e tutora do Programa de Residência Integrada Multiprofissional em Urgência e Emergência da UNIPAMPA. Coordenadora e membro do Núcleo Docente Estruturante do Curso de Enfermagem da UNIPAMPA. 


\section{JUCÉLIA RODRIGUES OLIVEIRA}

Graduanda do curso de Tecnologia em Radiologia pela Universidade Estadual de Ciências da Saúde de Alagoas

\section{LARA DE SÁ NEVES LOUREIRO}

Enfermeira no Hospital Universitário Lauro Wanderley - HULW, doutora em enfermagem pelo Programa de Pós-Graduação em enfermagem da Universidade Federal da Paraiba (UFPB), na área de concentração: Cuidado em Enfermagem e Saúde (2015). Docente na disciplina Atenção à Saúde do Idoso do curso de Medicina da Faculdade Ciências Médicas da Paraíba.

\section{LAURA ANDRADE ALMEIDA}

Acadêmica de medicina do Centro Universitário de Belo Horizonte - Unibh. Atualmente realizando estágio em Centros de Saúde em Belo Horizonte e região metropolitana. Tenho interesse em me especializar em oftalmologia ou em cuidados paliativos.

\section{LETÍCIA BITTENCOURT TURRA}

Graduação em Farmácia (em andamento) Universidade Federal de Santa Maria, UFSM, Brasil.

\section{LUCIANE MIRANDA GUERRA}

Docente da área de Psicologia Aplicada, do Departamento de Odontologia Social da Faculdade de Odontologia de Piracicaba - FOP-UNICAMP. Doutora em Odontologia - área de concentração Saúde Coletiva - pela FOP-Unicamp. Mestre em Odontologia Legal e Deontologia pela FOP-Unicamp e especialista em Saúde Coletiva pela FOP-Unicamp. Coordenadora do Programa de Mestrado Profissional em Odontologia em Saúde Coletiva da FOP-UNICAMP, onde também participa de pesquisas na área de saúde coletiva. Docente Permanente do Programa de Pos Graduação em Odontologia da FOP-Unicamp -área de concentração: saúde coletiva.

\section{LUISA ANDRADE DE ALMEIDA}

Acadêmica de medicina do Centro Universitário de Belo Horizonte - UNIBH. Desenvolvimento de prática médica ambulatorial em curso com atuação em UBS e na Clínica Integrada do UniBh. Tenho interesse nas especialidades de Geriatria e Psiquiatria. Em busca de novos projetos e conhecimentos.

\section{MARCELA DOS SANTOS TEIXEIRA}

Pós Graduada em fisioterapia Neurofuncional pela Universidade Paulista (UNIP).

\section{MARIA AUXILIADORA PEREIRA}

Professora Associada 3 da Universidade Federal da Paraíba, lotada no Departamento de Enfermagem Clínica do Centro de Ciências da Saúde. Doutora em Enfermagem pela Universidade Federal da Paraíba (2015).

\section{MARIA DAS GRAÇAS MELO FERNANDES}

Professora titular da Universidade Federal da Paraíba, com atuação na Graduação e Pós-Graduação em Enfermagem, Líder do Grupo de Estudos e Pesquisa em Saúde do Adulto e do Idoso (GEPSAI). Doutorado em Ciências da Saúde pela Universidade Federal da Paraíba (2003) e Doutorado em Sociologia também pela Universidade Federal da Paraíba (2009). 


\section{MARÍA DEL CARMEN NAVARRO RODRÍGUEZ}

Profesora en el Departamento de Enfermería de la Universidad de Las Palmas de Gran Canaria. Doctora en Medicina.

\section{MARÍA JOSÉ MORALES-GÁZQUEZ}

Profesora en el Departamento de Enfermería. Formación académica: Diplomada Universitaria en Enfermería en 1994, Licenciada en Antropología Social y Cultural en 2001, Diploma de Estudios Avanzados en 2008, Doctora por la Universidad de Las Palmas de Gran Canaria en 2016. Otra formación predoctoral: Experto Universitario en Enfermería Comunitaria en 1994 y Máster en Gerontología Social y Aplicada en 2002. En el ámbito de la investigación he participado en multitud de congresos tanto como ponente como en comités científicos.

\section{MARINA GONTIJO TUYAMA}

Acadêmica de medicina do sexto período da Faculdade Ciências Médicas de Minas Gerais , com experiência em consultas e estágios nos Centros de Saúde de Belo Horizonte e região, onde atua como auxiliar de médicos e enfermeiros. Apresenta participação em elaboração de capítulos de livro e artigos científicos.Apresenta interesse em pediatria.

\section{MARLEIDE MATEUS DE JESUS}

Pedagoga. Professora de Matemática. Especialista em Gestão Escolar, Supervisão e Orientação (UNIASSELVI). Especialista em Metodologia do Ensino de Matemática (UNIASSELVI). Psicopedagoga (UNIASSELVI). Especialista em Saúde Escolar (UESC). Especialista em Educação, Cultura e Diversidade (UNIASSELVI). Agente Comunitária de Saúde do município de Itabuna - BA.

\section{MARTTA LAIANY MARTINS MACHADO}

Possui graduação em Radiologia pela Universidade Estadual de Ciências da Saúde de Alagoas (2019), atualmente cursa Especialização em Radioterapia no Instituto Nacional de Câncer, INCA.

\section{MICHELE BULHOSA DE SOUZA}

Possui graduação em Enfermagem e Obstetrícia pela Universidade Federal do Rio Grande (2004), Graduação em Licenciatura em Enfermagem pela Universidade Federal do Rio Grande (2004) e Mestrado em Enfermagem pela Universidade Federal do Rio Grande (2006). Atualmente é Professora Adjunto I do Curso de Enfermagem da Universidade Federal do Pampa, atuando na área Materno-Infantil, Fundamentos de Enfermagem e Ética. É vice-líder do Grupo de Estudos e Pesquisas na Atenção a Saúde da Criança (GEPASC) e participa do Grupo de Estudos e Pesquisa em Estágio e Formação de Professores (GEPEF). Doutoranda no PPG Educação em ciências: química da vida e saúde na UNIPAMPA.

\section{MILAGROS TORRES-GARCÍA}

Profesora en el Departamento de Didácticas especiales de la Universidad de Las Palmas de Gran Canaria. Licenciada en Farmacia. Doctora en Medicina.

\section{MIRELA TONETO VIEIRA}

Enfermeira, Faculdade Integrada de Santa Maria (FISMA). Pós Graduanda em Estratégia da Saúde da Família pela Faculdade Dom Alberto de Santa Cruz do Sul/RS. 


\section{NARA HELLEN CAMPANHA BOMBARDA}

Cirurgiã-Dentista - Faculdade de Odontologia de Barretos - Fundação Educacional de Barretos. Doutora em Reabilitação Oral - Universidade Estadual Paulista, Faculdade de Odontologia de Araraquara (UNESP). Professora Adjunto C do Departamento de Odontologia - Universidade Estadual de Ponta Grossa (UEPG). Coordenadora do Programa de Pós-Graduação Stricto Sensu em Odontologia - Universidade Estadual de Ponta Grossa (UEPG).

\section{NAYARA ALVES SEVERO}

Graduada em Educação Física (Faculdade Montenegro). Especialista em Educação Física Escolar (Un. Estácio de Sá). Mestre em Ciências e Técnicas Nucleares (UFMG). Doutora em Ciências e Técnicas Nucleares (UFMG). Professora Adjunta do Dep. Ciências da Saúde (UESC). Coordenadora do Curso de Especialização em Saúde Escolar (UESC). Coordenadora do Programa Residência Pedagógica de Educação Física (UESC).

\section{PATRYCIA BATISTA NERY SILVA}

Pedagoga (UESC). Especialista em Saúde Escolar (UESC). Professora da Educação Básica de Ensino e Vice-Diretora na Rede Municipal de Ensino de Itabuna - BA.

\section{RAFAELA VALADARES ZUCCONI}

Acadêmica do curso de medicina no Centro Universitário de Belo Horizonte (UniBH), com experiência em consultas e estágios nos Centros de Saúde de Belo Horizonte e região, onde atua como auxiliar de médicos e enfermeiros. Apresenta interesse em ginecologia e psiquiatria, é engenhosa e bem organizada.

\section{RAQUEL MENDES RUBENICK}

Enfermeira Faculdade Integrada de Santa Maria (FISMA). Técnica de Enfermagem do Hospital Federal de Santa Maria HUSM/ RS.

\section{REGIANE DE SILVA MACUCH}

Doutora em Ciências da Educação, Universidade do Porto, Portugal. Docente do Programa de PósGraduação em Promoção da Saúde - UNIVERSIDADE CESUMAR.

\section{ROSANA MARQUES SILVA FIGUERÔA}

Cirurgiã-Dentista - Universidade Estadual de Ponta Grossa (UEPG). Mestre e Doutora em Odontologia - Universidade Estadual de Ponta Grossa (UEPG). Professora Colaboradora do Departamento de Odontologia - Universidade Estadual de Ponta Grossa (UEPG).

\section{SAMANTA SANTANA DA SILVA}

Enfermeira. Pós Graduada em Enfermagem Ginecológica, Obstétrica e Neonatal pela Faculdade Pitágoras de Feira de Santana-BA. Especialista em Saúde Escolar (UESC). Enfermeira efetiva pela Secretaria Municipal de Saúde de Itabuna-BA.

\section{SANDRO MENEZES DE OLIVEIRA}

Enfermeiro. Biológo. Bacharel Interdisciplinar em Saúde. Especialista em Modelos de Cuidado (FIESP). Especialista em Acupuntura (IMAM). Especialista em Saúde Escolar (UESC). Supervisor do Programa de Agentes Comunitários de Saúde de Itabuna - BA. 


\section{SILVIA ANDRADE LOPES}

Acadêmica de medicina do Centro Universitário de Belo Horizonte (UniBH), com experiência em consultas e estágios nos Centros de Saúde de Belo Horizonte e região, onde atua como auxiliar de médicos e enfermeiros. Apresenta interesse em cirurgia e oftalmologia.

\section{SILVIA ROBERTA DE LIMA CARDOSO}

Enfermeira, Faculdade Integrada de Santa Maria (FISMA). Pós Graduanda em Nefrologia pela Faculdade Dom Alberto de Santa Cruz do Sul/RS. Docente de Técnicas em Hemodiálise SENAC RS Porto Alegre/RS.

\section{SIMONE SANTOS NUNES}

Enfermeira Doutora em Enfermagem pela Universidade Federal do Rio Grande - FURG; Doutorado sanduíche na Universidad de Múrcia - UM - Espanha. Docente da Faculdade Integrada de Santa Maria (FISMA).Santa Maria RS.

\section{TAINA WENDLING GAMA}

Acadêmica do sétimo período do curso de medicina do Centro Universitário de Belo Horizonte, com experiencia em consultas e estágios nos Centros de Saúde de Belo Horizonte e na Clinica Integrada da UniBH, onde atua como auxiliar de médicos e enfermeiros. Participações como palestrante e organizadora de simpósios científicos, elaboração de artigos científicos e resumos publicados em revista indexada e em capítulos de livros. Apresento interesse na área de cirurgia, cardiologia e neurologia. Sou boa em me relacionar com outros profissionais e demonstrar proatividade e organização nos trabalhos individuais e em equipe.

\section{TÂNIA MACHADO DE CARVALHO}

Especialista em Psicopedagogia Clínica e Institucional (Institutos Superiores de Ensino do Censa) e graduanda do Curso de Fonoaudiologia do Centro Universitário Fluminense (UNIFLU), Professora da rede pública do estado do Rio de Janeiro (SEEDUC) .

\section{VALDEIR ALMEIDA SANTOS}

Pedagoga. Especialista em Educação Infantil. Especialista em Saúde Escolar (UESC). Especialista em Atendimento Educacional Especializado. Especialista em Gestão Pública. Graduanda em Psicologia (FTC). Mestranda em Educação (FUNIBER).

\section{VANESSA MIGLIORINI URBAN}

Cirurgiã-Dentista - Universidade Estadual Paulista, Faculdade de Odontologia de Araraquara (UNESP). Mestre e Doutora em Reabilitação Oral - Universidade Estadual Paulista, Faculdade de Odontologia de Araraquara (UNESP). Professora Adjunto C do Departamento de Odontologia Universidade Estadual de Ponta Grossa (UEPG). Coordenadora do Projeto de Extensão "Produção de vídeos didático-pedagógicos para o Canal Remov Online".

\section{VERIDIANA DE VASCONCELOS DUARTE}

Formação: Analista de Sistemas - UCPel, Marketing - Unicesumar Pós-graduada: Educação, Docência e Gestão em Saúde - UNICESUMAR Mestre em Comunicação - UNIMAR Doutoranda em Promoção da Saúde - UNICESUMAR 


\section{ZENAIRA DA SILVA SANTOS}

Apresenta Licenciatura e bacharelado em Geografia desenvolvidos no Instituto de Geociências da Universidade Federal Fluminense do Rio de Janeiro (UFF/RJ). Atualmente é mestranda em Geografia na Universidade Federal de Goiás (PPGEO IESA/UFG). 
www.poisson.com.br contato@poisson.com.br

@editorapoisson 